
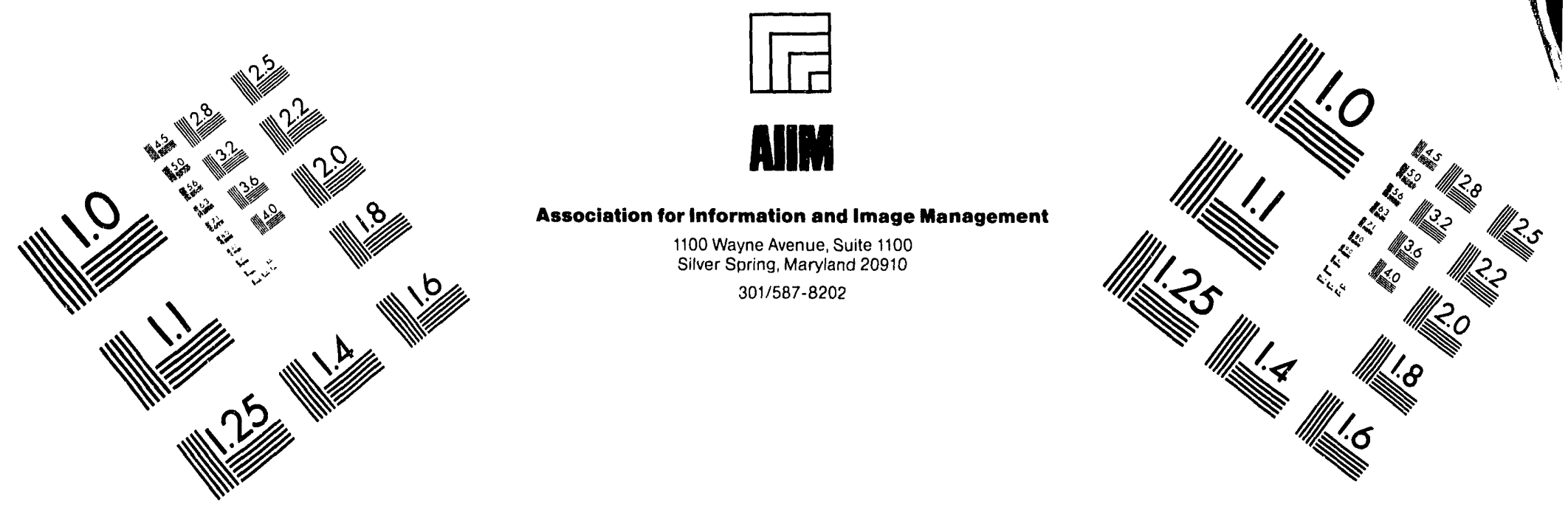

\title{
Centimeter
}

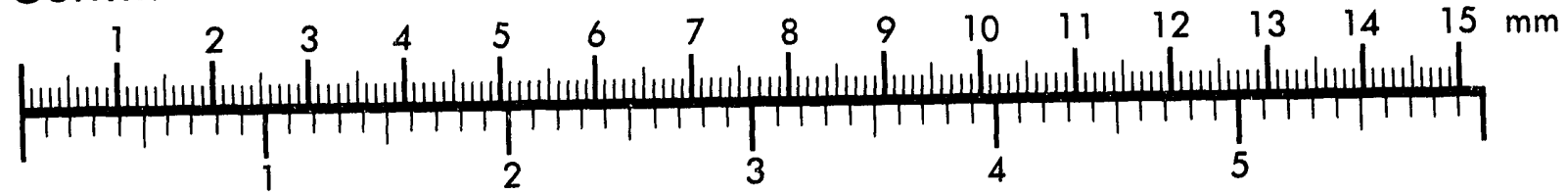
Inches
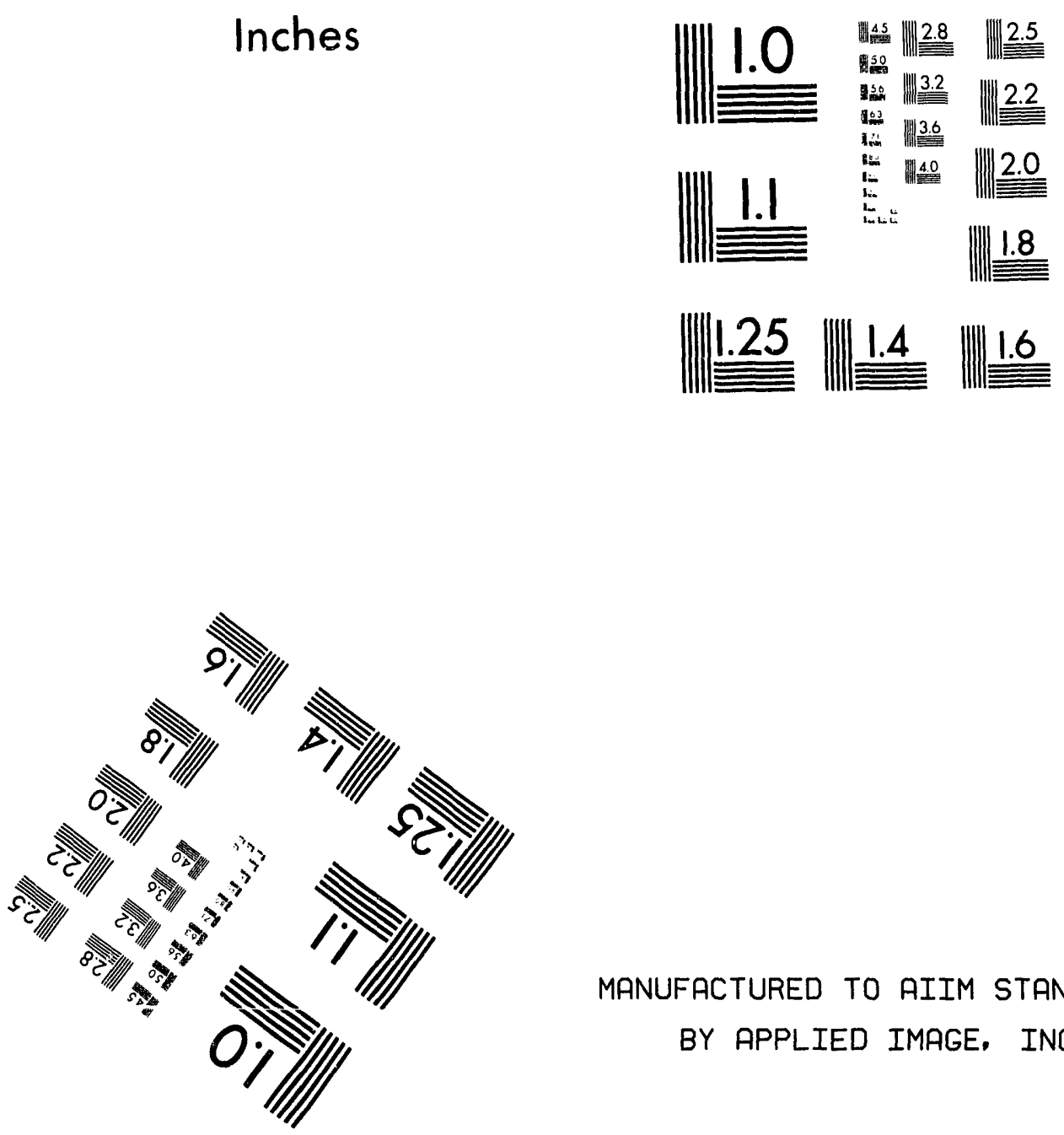

MANUFACTURED TO AIIM STANDARDS

BY APPLIED IMAGE, INC.

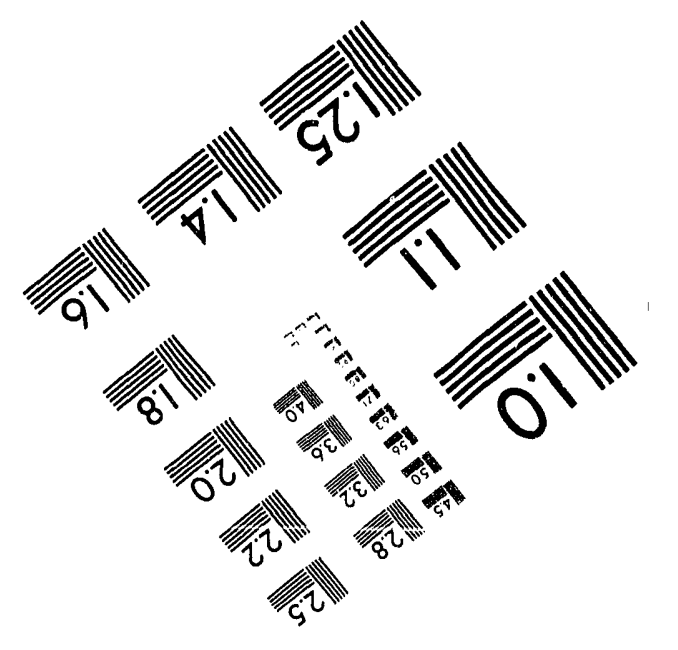



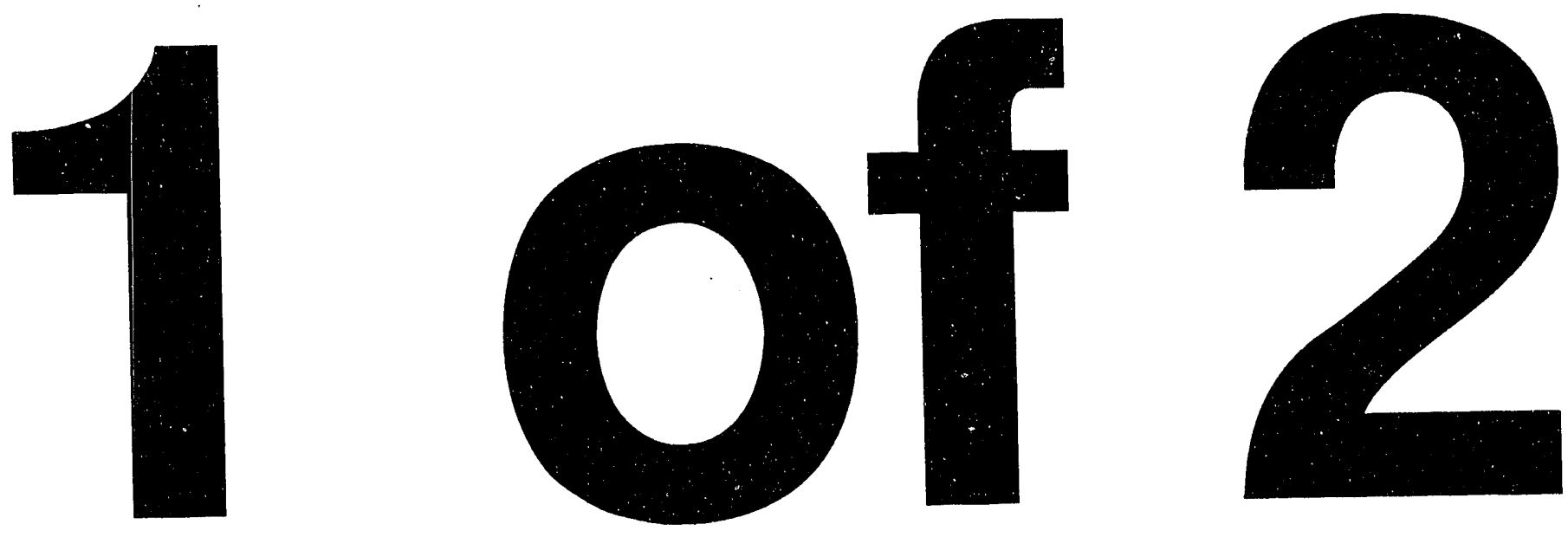
ORNL-6736

Environmental Sciences Division

\section{A GEOGRAPHIC INFORMATION SYSTEM APPROACH TO MODELING NUTRIENT AND SEDIMENT TRANSPORT}

Daniel A. Levine', Carolyn T. Hunsaker ${ }^{2}$, Sidey P. Timmins ${ }^{3}$, and John J. Beauchamp ${ }^{4}$

${ }^{1}$ Automated Sciences Group, Inc., 800 Oak Ridge Turnpike, Oak Ridge TN 37830

${ }^{2}$ Environmental Sciences Division, ORNL, P.O. Box 2008, Oak Ridge, TN 37831

${ }^{3}$ Analysas Corporation, 151 Lafayette Drive, Oak Ridge, TN 37830

${ }^{4}$ Engineering Physics and Mathematics Division, ORNL, P.O. Box 2008, Oak Ridge, TN 37831

Environmental Sciences Division

Publication No. 3993

Date Published: February 1993

Prepared by the

Environmental Sciences Division

OAK RIDGE NATIONAL LABORATORY

Oak Ridge, Tennessee 37831-6285

Managed by

MARTIN MARIETTA ENERGY SYSTEMS, INC.

for the

U.S. DEPARTMENT OF ENERGY

under contract DE-AC05-84OR21400 


\section{CONTENTS}

\section{Page}

LIST OF FIGURES $\ldots \ldots \ldots \ldots \ldots \ldots \ldots \ldots \ldots \ldots \ldots \ldots \ldots \ldots \ldots$

LIST CF TABLES $\ldots \ldots \ldots \ldots \ldots \ldots \ldots \ldots \ldots \ldots \ldots \ldots \ldots \ldots \ldots$

ACKNOWLEDGMENT $\ldots \ldots \ldots \ldots \ldots \ldots \ldots \ldots \ldots \ldots \ldots \ldots \ldots \ldots$

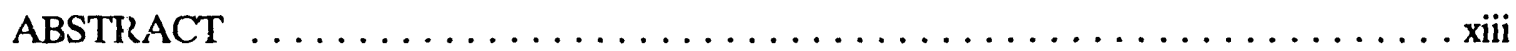

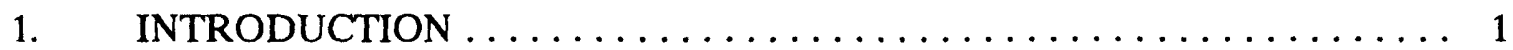

1.1 NUTRIENT- AND SEDIMENT-LOADING MODELS $\ldots \ldots \ldots \ldots 2$

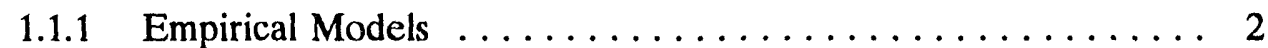

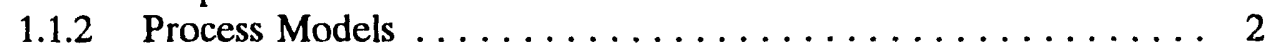

1.1.3 Using GIS to Integrate Spatial

Parameters with Empirical Models .............. 3

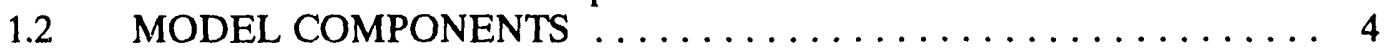

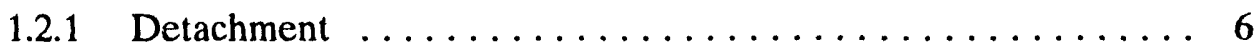

1.2.1.1 Sediment ..................... 6

1.2.1.2 Nutrients ....................... 6

1.2.2 Overland Flow Delivery $\ldots \ldots \ldots \ldots \ldots \ldots \ldots \ldots \ldots$

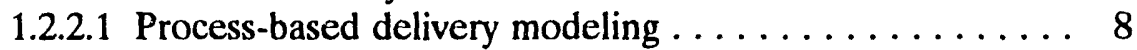

1.2.2.2 Empirical delivery ratios $\ldots \ldots \ldots \ldots \ldots \ldots \ldots . \ldots 9$

1.2.2.3 Vegetated filter strips $\ldots \ldots \ldots \ldots \ldots \ldots \ldots \ldots \ldots$

1.2.3 Channel Flow Delivery . . . . . . . . . . . . . . . 11

1.2.3.1 Process-based delivery modeling $\ldots \ldots \ldots \ldots \ldots \ldots 11$

1.2.3.2 Empirical delivery modeling $\ldots \ldots \ldots \ldots \ldots \ldots \ldots 12$

1.2.3.3 Stream network delineation . . . . . . . . . . . 12

1.2.4 Hydrologic Flow Path Delivery Ratios . . . . . . . . . . . 14

1.2.4.1 Flow path determination .............. 14

1.2.4.2 Sequential accumulation of delivery ratios $\ldots \ldots \ldots 14$

$1.3 \quad$ HYPOTHESES ......................... 14

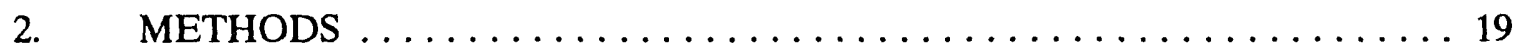

2.1 WATERSHED DESCRIPTION ................. 19

2.1.1 Physiographic Region Within Ray Roberts Watershed ....... 19

2.1 .2 Climate .......................... 28

2.2 WATER QUALITY DATA ................... 28

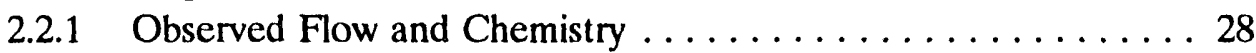

2.2.2 Calculation of Observed Annual Loads . . . . . . . . . . 29 


\section{CONTENTS}

Page

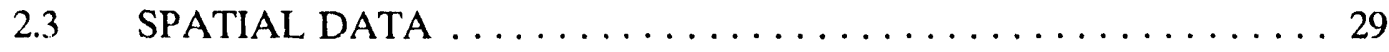

2.3.1 Land Use/Land Cover $\ldots \ldots \ldots \ldots \ldots \ldots \ldots \ldots \ldots \ldots$

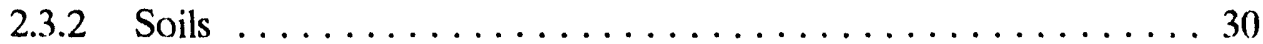

2.3.3 Road Network . ........................ 31

2.3.4 Watersheds, Streams, and Elevation Contours ........... 31

2.3.4.1 Creating digital elevation models $\ldots \ldots \ldots \ldots \ldots . \ldots 34$

2.3.4.2 Slope and direction of flow $\ldots \ldots \ldots \ldots \ldots \ldots 36$

2.4 POTENTIAL LOAD ESTIMATION $\ldots \ldots \ldots \ldots \ldots \ldots \ldots \ldots \ldots$

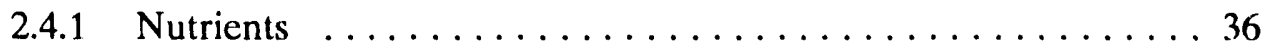

2.4.2 Sediments ................................ 38

2.5 CELL DELIVERY RATIO MODELS $\ldots \ldots \ldots \ldots \ldots \ldots \ldots \ldots$

2.5.1 Selection of Vegetative Filter-Strip Studies . . . . . . . . . 39

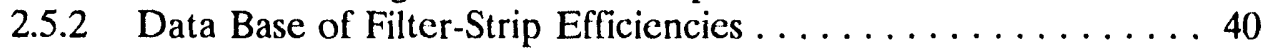

2.5.3 Statistical Analysis ..................... 41

2.5.3.1 Linear Regression Equations .............. 42

2.5.3.2 Nonlinear Regression Equations $\ldots \ldots \ldots \ldots \ldots \ldots 44$

2.6 MODELING PROCEDURE $\ldots \ldots \ldots \ldots \ldots \ldots \ldots \ldots \ldots \ldots$

2.6.1 Calculate Cell Delivery Ratios . . . . . . . . . . . . . . . 46

2.6.2 Transport to Mainframe $\ldots \ldots \ldots \ldots \ldots \ldots \ldots \ldots \ldots 48$

2.6.3 Define Stream Network $\ldots \ldots \ldots \ldots \ldots \ldots \ldots \ldots . \ldots 48$

2.6.4 Overlay Stream Network onto Delivery File .......... 49

2.6.5 Calculate Total Flow Path Delivery Ratios ............ 49

2.6.6 Transport to Personal Computer ................. 49

2.6.7 Calculate Total Annual Load ................... 50

2.6.8 Compare Estimated Load to Observed Load ............. 50

2.6.9 Calibration ............................ 50

3. RESULTS AND DISCUSSION $\ldots \ldots \ldots \ldots \ldots \ldots \ldots \ldots \ldots \ldots \ldots$

3.1 OBSERVED LOAD CALCULATIONS $\ldots \ldots \ldots \ldots \ldots \ldots \ldots \ldots 50$

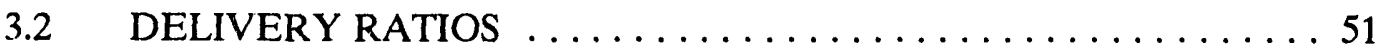

3.2.1 Linear Models ....................... 51

3.2.1.1 Mass Regression Models ................ 51

3.2.1.2 Concentration Regression Models ........... 59

3.2.1.3 Determination of Effective Buffer Strip Length . . . . . 60

3.2.2 Nonlinear Models $\ldots \ldots \ldots \ldots \ldots \ldots \ldots \ldots \ldots \ldots, 60$

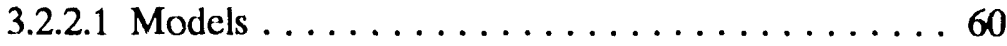

3.2.2.2 Sensitivity Analysis $\ldots \ldots \ldots \ldots \ldots \ldots \ldots 62$

3.2.3 Limits of Models . . . . . . . . . . . . . . . . . . 65 


\section{CONTENTS}

Page

3.3 POTENTIAL LOAD ESTIMATION $\ldots \ldots \ldots \ldots \ldots \ldots \ldots \ldots, \ldots 9$

3.4 MODEL CALIBRATION ..........................6 69

3.4.1 Eastern Cross Timbers Physiographic Region . .......... 69

3.4.2 Blackland Prairie Physiographic Region ............... 69

3.4.3 Grand Prairie Physiographic Region ................ 74

3.5 ANNUAL LOAD ESTIMATES $\ldots \ldots \ldots \ldots \ldots \ldots \ldots \ldots \ldots \ldots \ldots$

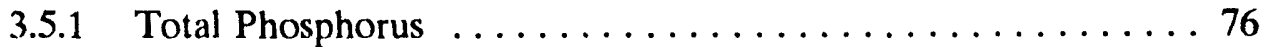

3.5 .2 Total Nitrogen $\ldots \ldots \ldots \ldots \ldots \ldots \ldots \ldots \ldots \ldots \ldots \ldots, 78$

3.5.3 Total Suspended Solids $\ldots \ldots \ldots \ldots \ldots \ldots \ldots \ldots \ldots \ldots . \ldots . \ldots . \ldots 79$

3.6 REGIONAL ANALYSIS OF MODEL $\ldots \ldots \ldots \ldots \ldots \ldots \ldots . \ldots$

3.6.1 Eastern Cross Timbers Physiographic Region .......... 80

3.6.2 Blackland Prairie Physiographic Region .............. 80

3.6.3 Grand Prairie Physiographic Region .............. 81

3.7 LOAD CONTRIBUTING AREA ANALYSIS $\ldots \ldots \ldots \ldots \ldots \ldots 81$

3.7.1 Pollutant Comparisons . ................... 81

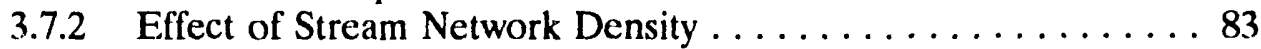

3.8 MODEL EFFICIENCY $\ldots \ldots \ldots \ldots \ldots \ldots \ldots \ldots \ldots \ldots, \ldots \ldots$

3.9 MANAGEMENT IMPLICATIONS $\ldots \ldots \ldots \ldots \ldots \ldots \ldots \ldots, 90$

3.10 CONCLUSIONS $\ldots \ldots \ldots \ldots \ldots \ldots \ldots \ldots \ldots \ldots \ldots \ldots, \ldots \ldots \ldots$

4. FUTURE RESEARCH $\ldots \ldots \ldots \ldots \ldots \ldots \ldots \ldots \ldots \ldots \ldots \ldots$

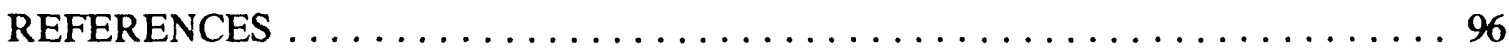

APPENDIX A. .................................... 109

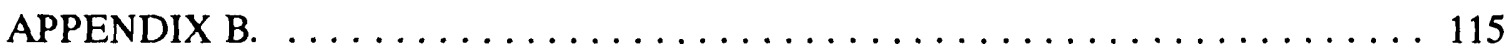

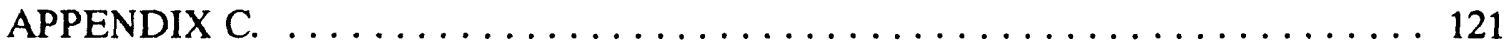

APPENDIX D. .................................... 129

APPENDIX E. .................................... 139

APPENDIX F. . . . . . . . . . . . . . . . . . . . . . . . . . 147 


\section{LIST OF FIGURES}

Figure

Page

1.1 Conceptual model of the sediment- and nutrient-loading process $\ldots \ldots \ldots \ldots$

1.2 Sequential accumulation of cell delivery ratios into total flow path $\ldots \ldots \ldots 15$

1.3 Calculation of total nutrient and sediment load $\ldots \ldots \ldots \ldots \ldots$

$2.1 \quad$ Relative location of Lake Ray Roberts watershed study area $\ldots \ldots \ldots \ldots 22$

2.2 Texas counties within the Lake Ray Roberts watershed study area . . . . . 23

2.3 Land-use distribution within the Lake Ray Roberts watershed . . . . . . . 24

2.4 Soils texture class distribution within the Lake Ray Roberts watershed . . . . . 25

2.5 Watersheds within the Lake Ray Roberts watershed $\ldots \ldots \ldots \ldots \ldots$

2.6 Physiographic regions within the Lake Ray Roberts watershed area . . . . 27

2.7 Primary and secondary road network in the Lake Ray Roberts area . . . . . 32

2.8 USGS 1:24,000 quads that encompass the Lake Ray Roberts watershed and are used to obtain elevation contours and stream networks .......... 33

2.9 Graphical representation of theoretical data space and actual data space used to develop multiple regression models $\ldots \ldots \ldots \ldots \ldots \ldots$

$2.10 \quad$ Flowchart of modeling procedure $\ldots \ldots \ldots \ldots \ldots \ldots \ldots \ldots \ldots \ldots$

3.1 Sensitivity analysis of nonlinear total phosphorus model $\ldots \ldots \ldots \ldots 3$

3.2 Sensitivity analysis of nonlinear total nitrogen model $\ldots \ldots \ldots \ldots$

3.3 Sensitivity analysis of nonlinear total suspended solids model $\ldots \ldots \ldots 6$

3.4 Calibration of the model in Timber Creek watershed for total phosphorus load 71

3.5 Calibration of the model in Timber Creek watershed for total nitrogen load . . 72 


\section{LIST OF FIGURES}

$\begin{array}{lll}\text { Figure Page } & \text { Pand }\end{array}$

3.6 Calibration of the model in Timber Creek watershed for total suspended solids load. . . . . . . . . . . . . . . . . . . . . . . . . . 73

3.7 Grayshade representation of the stream network as delineated from the COUNT program for a small portion of the Timber Creek watershed using six different COUNT thresholds . . . . . . . . . . . . . . . . . . . . 75

3.8 Average contributing area for total phosphorus, total nitrogen, and total suspended solids for watersheds run using three different COUNT thresholds .84

3.9 Grayshade representation of the area contributing total phosphorus load using three different COUNT thresholds in a small portion of the

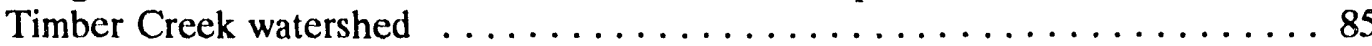

3.10 Percent delivery of total suspended solids from a small portion of the

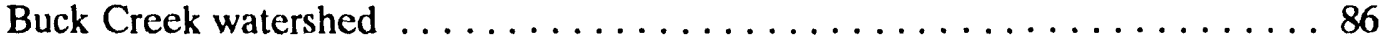

3.11 Percent delivery of total phosphorus from a small portion of the Buck Creek watershed. . . . . . . . . . . . . . . . . . . . 87

3.12 Percent delivery of total nitrogen from a small portion of the Buck Creek watershed 


\section{LIST OF TABLES}

Table

Page

2.1 Total area and percentage of land-use/land-cover types in 12 sub-watersheds within the Lake Ray Roberts watershed . . . . . . . . . . . . . . 20

2.2 Total area and percentage of soil textural class in 12 sub-watersheds within

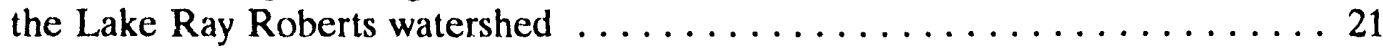

2.3 UTM minimum and maximum coordinates and IDRISI array dimensions for

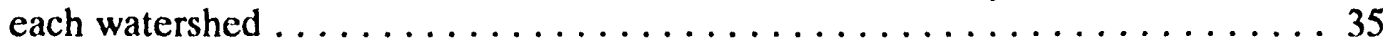

2.4 Export coefficients as used for total phosphorus and total nitrogen

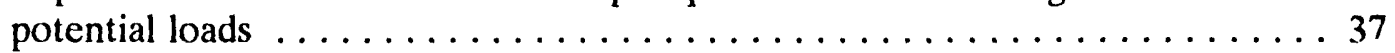

2.5 Cover and management factor $(C)$ used in the USLE model . . . . . . . 39

2.6 Manni.ig's roughness coefficient $(n)$ assigned to land uses in the delivery ratio program.

3.1 Linear models of vegetated filter-strip-trapping efficiency for mass of ammonia nitrogen (A), nitrate nitrogen (B), total nitrogen (C), total phosphorus (D),

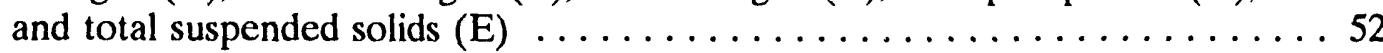

3.2 Linear models of vegetated filter-strip-trapping efficiency for concentration of ammonia nitrogen $(A)$, nitrate nitrogen $(B)$, total nitrogen $(C)$, total phosphorus (D), and total suspended solids (E)

3.3 Minimum and maximum limits of data used to develop the linear models of vegetated filter-strip-trapping efficiency for mass of ammonia nitrogen (A), nitrate nitrogen (B), total nitrogen (C), total phosphorus (D), and total

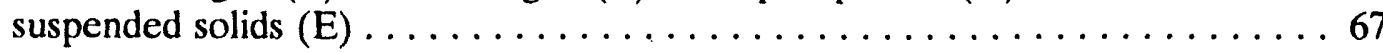

3.4 Minimum and maximum limits of data used to develop the linear models of vegetated-filter-strip trapping efficiency for concentration of ammonia nitrogen (A), nitrate nitrogen (B), total nitrogen (C), total phosphorus (D), and total

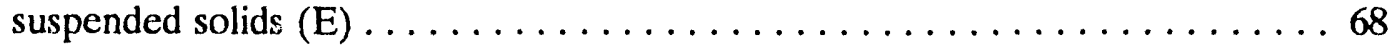

3.5 Total annual observed and estimated loads calculated from potential loads only 70 


\section{LIST OF TABLES}

Table

Page

3.6 Total annual observed and model estimated loads for all watersheds for total phosphorus, total nitrogen, and total suspended solids . . . . . . . . 77

3.7 Percent area of each watershed contributing to total phosphorus, total nitrogen, and total suspended solids load 


\section{ACKNOWLEDGMENTS}

This work was performed in partial fulfillment of the doctor of philosophy degree in environmental science from the School of Public and Environmental Affairs at Indiana University.

Research was supported partially by the Landscape Characterization Project, Environmental Monitoring and Assessment Program, of the U.S. Environmental Protection Agency, under Interagency Agreement DW89934921-01 with the U.S. Department of Energy, under Contract DE-AC05-84OR21400 with Martin Marietta Energy Systems, Inc.

Although the research described in this article has been funded in part by the U.S. Environmental Protection Agency, it has not been subjected to agency review. Therefore, it does not necessarily reflect the views of the agency. Any mention of trade names or commercial products does not constitute endorsement or recommendation for use. 


\begin{abstract}
The objective of this study was to develop a water quality model to quantify nonpoint-source (NPS) pollution that uses a geographic information system (GIS) to link statistical modeling of nutrient and sediment delivery with the spatial arrangement of the parameters that drive the model. The model predicts annual nutrient and sediment loading and was developed, calibrated, and tested on 12 watersheds within the Lake Ray Roberts drainage basin in north Texas. Three physiographic regions are represented by these watersheds, and model success, as measured by the accuracy of load estimates, was compared within and across these regions.

Through a synthesis of vegetative filter strip research, we developed equations that calculate the delivery ratios for total phosphorus, total nitrogen, and total suspended solids based on distance of flow, slope angle, surface roughness as expressed by land cover, soil permeability, and soil mean particle diameter. A raster-based GIS uses these equations to calculate transport (expressed as delivery ratios) of the three materials across each cell in a watershed. The model uses a digital elevation model to determine the flow path from each cell within a watershed to the watershed outlet. Total flow path delivery is then calculated by sequentially multiplying cell delivery ratios together for every cell along each flow path.

Potential loadings of total phosphorus and nitrogen are assigned to each cell on the basis of land use. Another GIS module calculates potential sediment yield from each cell using the universal soil loss equation. The potential load file for each pollutant is multiplied by the total flow path delivery ratio file to obtain total mass of nutrients and sediment delivered from each cell in the watershed. The output of the model includes the annual load of phosphorus, nitrogen, and sediment outlet and a map representing the mass of nutrients and sediment contributed from each cell. The model is calibrated by increasing the stream network density (where cell delivery ratios equal 100\%) and thus effectively increasing the total watershed area contributing sediment and nutrients.
\end{abstract}




\section{INTRODUCTION}

During the early implementation of the Clean Water Act (CWA) of 1977, the U.S. Environmental Protection Agency (EPA) focused its regulatory efforts on discharges from large point sources such as factory and wastewater treatment effluent. Now that the majority of these discharges have been identified and regulated, EPA has turned its attention to the problem of nonpoint-source (NPS) pollution. In a 1984 report to Congress, EPA concluded that NPS pollution was a leading cause of the remaining water quality problems facing the nation. In the summer of 1991 numerous scientists and water quality managers testified to co.igressional subcommittees that were faced with the task of reauthorizaion of the CWA that the NPS program within the CWA was critical to the protection of the nation's waters. Currently, Sect. 208 of the CWA requires that regional assessments and plans be developed to address NPS pollution. Section 319 provides the framework for addressing NPS pollution, specifically putting most of the responsibility on the states. When the CWA is reauthorized, probably sometime in 1992, there will very likely be a stronger emphasis on NPS pollution control and abatement. This will put more pressure on state agencies to identify and mitigate problems of NPS pollution.

The understanding and management of water quality problems resulting from NPS pollution require knowledge of the strength of pollution sources and of the delivery of pollutants from the source to the receiving waters (Novotny and Chester 1989). NPS water quality models have been under development for 20 years to address this need. As a result, local, state, and regional planners and managers have been bombarded with a plethora of these models, which range from very simple to extremely complex. These models are based on empirical relationships, theoretical processes, or a combination of the two. Selecting an appropriate model is a major decision in itself. Typically, planners and managers shy away from the data-intensive, process-based models and choose the easy-touse empirical models. Reasons include the process-based model requirements of large amounts of data that are often unavailable, expensive computers, and a long lead time for calibration and verification. Generally, empirical models are less data-, computer-, and time-intensive than process-based models. However, selecting an empirical model, a decision maker has automatically limited one's decision-making ability, because empirical models lack temporal and spatial resolution.

The objective of this study was to develop a water quality model that quantifies NPS pollution loads and links statistical modeling of nutrient and sediment delivery with the spatial arrangement of the parameters that drive the model. In a review article on sediment and pollutant delivery from nonpoint sources, Novotny and Chesters (1989) concluded that models that quantify each component of the delivery process (overland flow, vegetative filtration, and channel processes) are needed. They also concluded that delivery ratios describing these processes must be calculated in a temporally and spatially distributed or sequentially lumped approach. This research specifically addresses these needs by (1) developing statistical equations that calculate delivery ratios for sediment, phosphorus, and nitrogen; (2) applying these delivery ratio equations within spatially distributed watershed data bases and sequentially accumulating pollutant deliveries; and (3) using temporally distributed hydrologic information that determines the density of the active stream network to calibratc ihe model. 


\subsection{NUTRIENT- AND SEDIMENT-LOADING MODELS}

\subsubsection{Empirical Models}

Empirical models are generally in the form of a single equation that expresses the relationship between an easily measured parameter (e.g., land-use area) and a particular water quality parameter (e.g., total phosphorus). Many of these models, such as the Universal Soil Loss Equation (USLE) and unit-area-load models, have enjoyed widespread use and acceptance (Vollenwieder 1975; Omernik 1977; Reckhow 1979) despite their inherent uncertainties (Reckhow 1979; LaBaugh and Winter 1984). The relationships expressed in these models are usually based on a large number of watersheds across the country (Rast and Lee 1983) or are restricted to regions such as the midwest (McElroy et al. 1976) or a state (Clesceri et al. 1986). Typically, empirical models are not useful in modeling episodic events, but instead the models have focused on annual averages (Dickerhoff-Delwiche and Haith 1983, Haith and Shoemaker 1987, and many others). In addition to the lack of temporal resolution, until recently, these models have ignored the spatial distribution of the factors that affect the modeled parameters. When spatial factors are considered, they are generally in the form of average values for watersheds or subwatersheds. Lack of spatial information limits the ability of these models to describe processes governing water and nutrient movement across a landscape accurately.

\subsubsection{Process Models}

Several process-oriented models such as Agricultural Runoff Model (ARM) (Donigian et al. 1977), Chemical Runoff and Erosion from Agricultural Management Systems (CREAMS), (Knisel 1980), and Midwest Resource Inventory (MRI) (McElroy et al. 1976), incorporate the physical and chemical processes that drive nutrient transport. For instance, both the MRI and WRENS models calculate sediment yields with a modification of the USLE and multiply the result by an enrichment factor to obtain nitrogen or phosphorus loads. This is based on the theory that nutrient loads from overland flow are linked to sediment transport. These models, however, do not address effects of the spatial pattern of the input parameters on the processes and, therefore, the predicted nutrient loads. Instead, these models "lump" land form, land use, and physical processes into single average values for entire watersheds or sub-watersheds.

Some process-oriented models have addressed the problem of spatial variability of the independent parameters. These have been labeled "distributed models" (Li 1974, Lake 1977). $\mathrm{Li}$ (1974) developed a sediment transport model that divides a watershed into homogeneous units relative to shape, slope, and roughness. In these models the watershed is represented by a grid of cells. Flow of water and sediments between cells is modeled using conservation of mass equations. The Areal Nonpoint Source Watershed Environment Response Simulation (ANSWERS) (Beasley et al., 1980, Lake 1977) and Agricultural Nonpoint Source (AGNPS) Young et al. 1989a, 1989b) models are also distributed models that divide a watershed into a grid system. Although this format allows for the spatial variation in parameters to affect the outcome of the models, the models rely on calculations of sediment-carrying capacity of overland and channel flows to predict 
nutrient and sediment loading. Novotny and Chesters (1989) described several problems with this concept.

First, there are inherent uncertainties and inaccuracies in the equations available for overland sediment transport. Second, these equations use several parameters (e.g., surface roughness, vegetation, slope) that should be calibrated in a distributed fashion. This is impossible, and, as a result, these models are calibrated as one lumped unit. Finally, these models use cell sizes ranging from 1 to 16 ha (2.5 to 40 acres). This resolution is not fine enough to capture the resolution of the parameters that drive the models (Baun 1985).

The application of these process models has been limited to relatively small watersheds because the numeric calculations required for larger watcrsheds exceed computer capabilities. In addition, because these models are typically event-based, a large hydrologic data set, which is difficult to collect and manage, is required to run them for an entire year; therefore, their use is limited to short periods of time.

Incorporating spatial pattern into numerical modeling allows managers to identify critical management areas by locating catchments that contribute most of the nutrient load. However, the watershed or catchment resolution of information does not always provide adequate information to select and implement a management plan with confidence. It is inefficient to fund management actions throughout a catchment when a smaller area can be managed. Although some models do provide finer spatial resolution of the physical process governing nutrient movement, they require large amounts of data, expertise in water chemistry and computers, and specific computer hardware to run the models (Whitmore and Ice 1984). Furthermore, most existing models were developed for particular watersheds. Applying them to other watersheds, especially for large geographic areas, requires a great deal of data collection and model calibration. These limitations have restricted the use of process-oriented distributed models to research groups or state and federal agencies that have the necessary resources.

A method is needed to allow easier implementation of numerical models at a finer spatial resolution. Such a method would also be useful to generate maps, both on a computer monitor and on paper, that depict nutrient loads from each cell. The linking of a distributed model to a geographic information system (GIS) would allow a finer resolution of input and output variables and, therefore, provide important information relative to identifying critical management areas.

\subsubsection{Using GIS to Integrate Spatial Parameters with Empirical Models}

Although NPS models that use a GIS exist, until recently, they have been used only to predict hydrologic runoff and sediment and bacterial loads. For example, Berry and Sailor (1987) used a GIS to predict storm runoff in a small Connecticut watershed using the Soil Conservation Service (SCS) curve number method and a data base with a resolution of 0.4 ha (1 acre) cells. Regan and Fellows (1980) described a similar process using remotely sensed data [resolution of $80 \times 80 \mathrm{~m}$ (1.6 acres)] to identify land-use types and a GIS to calculate curve numbers. Several studies have used a GIS to implement the 
USLE for calculating potential soil loss (DelRegno and Atkinson 1988, Shanholtz et al. 1988, Levine and Jones 1990) with resolutions of $80 \times 80 \mathrm{~m}, 1$ ha $(2.5$ acres), and $20 \times$ $20 \mathrm{~m}$ ( 0.1 acres), respectively. Sediment yields were predicted by combining delivery ratios with the USLE results for relatively small cells within a GIS data base (DelRegno and Atkinson 1988; Hession and Shanholtz 1988). DelRegno and Atkinson (1988) further used their GIS data base to estimate the areas of different land-use types for calculating areal phosphorus loading in several Texas watersheds. In another study a GIS data base with a $20 \times 20 \mathrm{~m}$ resolution was developed to model bacteria concentrations in a stream draining a feedlot area in Oklahoma (Gilliland and BaxterPotter 1987). In each case, the GIS allowed the easy identification of critical source areas on a relatively high resolution map and rapid evaluation of management alternatives.

Recently, GIS techniques were developed to account for the spatial arrangement of the variables that control nutrient transport processes and for the way this arrangement ultimately affects nutrient movement across a landscape. The movement of nitrogen in the Walker Branch Watershed was modeled by linking a numerical model with a raster GIS (Bartell and Brenkert 1990). Researchers in Germany have developed a finiteelement-like model using $\mathrm{ARC} \mathrm{INFO}^{\otimes}$ (ESRI, 1987) as the host GIS to provide a shell for ecosystem modeling (Haber and Schaller 1988). This structure allows for nutrient modeling on a watershed scale but remains untested. New versions of ANSWERS and AGNPS use a GIS as a data input and output tool which allows both of these models to use data at a higher resolution (DeRoo et al. 1989, Engel et al. 1991). The link to GIS data bases also allows these event-based models to become annualized.

A gap still exists between the lumped empirical models and the distributed process models. I have developed a model that bridges this gap by applying widely accepted lumped empirical models in a distributed system. The model uses the unit-area-loads concept and applies it in a distributed system by multiplying the load by flow path delivery ratios specific to each cell. The flow path delivery ratios are determined by sequentially accumulating cell delivery ratios along hydrologic flow paths. Cell delivery ratios are calculated using a statistical model of empirical data.

\subsection{MODEL COMPONENTS}

Novotny and Chesters (1989) provided a graphical representation of the sediment delivery process, which I have modified to include nutrient delivery and to separate the overland and channel processes into individual components (Fig. 1.1). The model is

divided into three components. The detachment phase represents the initial mass of sediment or nutrients available for transport. The overland flow component represents the influence of surface conditions such as soil permeability, slope, and vegetation density on the delivery of sediment and nutrients during movement toward a stream channel. The channel component represents instream delivery. 
ORNL-DWG 92-14865

\begin{tabular}{|c|c|c|c|}
\hline $\begin{array}{c}\text { Soil Detachment } \\
\text { and Nutrient } \\
\text { Mobilization }\end{array}$ & $\begin{array}{l}\text { Overland Flow } \\
\text { Delivery Process }\end{array}$ & $\begin{array}{c}\text { Channel Flow } \\
\text { Delivery Process }\end{array}$ & $\begin{array}{l}\text { Sediment and } \\
\text { Nutrient Load }\end{array}$ \\
\hline
\end{tabular}

Fig. 1.1. Conceptual model of the sediment- and nutrient-loading process 


\subsubsection{Detachment}

\subsubsection{Sediment}

The detachment and mobilization of sediment and nutrients are driven by rainfall. Sediment and sediment- borne nutrients are detached from the soil matrix by raindrop impact with the ground, and soluble nutrients are mobilized when water flows through the soil matrix. Further detachment can occur from the energy of overland flow. There are models that use mathematical descriptions of these physical processes (Meyer and Wischmeier 1969, Beasley et al. 1980, Knisel 1980). They generally rely on particle size distributions of surface soil layers and are difficult to calibrate and verify.

There are empirical relationships that provide a simpler means of quantifying the detachment process. The USLE is an empirical model that calculates potential sediment yield on an annual basis (Wischmeier and Smith 1978) and on an event basis (Knisel 1980). The USLE was developed from multiple plots with varying soil conditions. All plots were $23.2 \mathrm{~m}$ long and had a $9 \%$ slope (Wischmeier 1976). The empirical equation was tested for 2300 plot-years on 189 plots across the country. Because of this strong empirical foundation and the general availability of input data, the USLE has enjoyed widespread acceptance. I employed the USLE to calculate sediment detachment.

\subsubsection{Nutrients}

The process models that estimate nutrient yield generally do so by linking the nutrient delivery to sediment delivery. Modeling the detachment phase of nutrient transport requires knowledge of the soil concentration of nutrients. This information is not widely available and is very expensive to generate. This has limited the use of these models. Additionally, success of this technique requires accurate estimates of sediment detachment. Any inaccuracies in sediment detachment estimates translate directly into errors in nutrient detachment estimates. This has limited the success of these models in accurately estimating observed yields. Estimates are often several orders of magnitude away from observed values (Lee 1987).

The literature on export coefficients (unit-area-loads) provides a source of empirical data useful for determining nutrient detachment estimates. I concentrate on total nitrogen and total phosphorus specifically because the available data sets are more nearly complete than are other constituents. Export coefficients were developed to drive the empirical loading models. Total area of a particular land use withir a watershed is multiplied by an export coefficient for phosphorus or nitrogen to estimate total nutrient load. Loads from all land uses in the watershed are totaled to estimate total nutrient loading. To generate these export coefficients, numerous researchers conducted studies on areas ranging from small plots to small watersheds that were monitored continuously for at least a year. Reckhow et al. (1980) compiled results from these studies into tables of export coefficients and study area descriptions. They recommend that the user select the appropriate export coefficient by matching the study area descriptions to the characteristics in the watershed being modeled. This approach has been widely accepted by water quality planners. 
These export coefficients inherently include a delivery factor. Because measurements are made at the outlet of a catchment, overland and channel delivery within the catchment are accounted for in the export value. However, if these export coefficients are applied to cells with areas similar to the catchment area from which they were derived, they can serve as estimates of nutrient detachment. This is how I estimate nutrient detachment in my model.

\subsubsection{Overland Flow Delivery}

Usually, empirical loading models are designed so that every part of a watershed contributes equally to the total loading. Osborne and Wiley (1988) suggested that this is not truly the case; a relatively small area adjacent to the receiving water actually contributes the majority of materials. From the results of their study, they concluded that as distance from the stream increased, the magnitude of contribution decreased exponentially. The actual nutrient- and sediment-contributing area is variable both temporally and spatially (Dunne et al. 1975). The extent of the area depends on soil characteristics, watershed morphology, land cover characteristics, and recent precipitation history.

The idea of distance affecting nutrient loading parallels the "variable source area runoff" concept developed by forest hydrologists (Hewlett 1961, Troendle 1979). Hydrologists have known for some time that the actual land area that contributes to storm runoff is a small and dynamic fraction of the total watershed area (Betson and Marius 1969, Tichendorf 1969, Hewlett and Troendle 1975, Troendle 1985, Hibbert and Troendle 1988). Simply stated, as rainfall intensity and duration increases, the area of land supplying water to a stream increases. During a storm, soil becomes saturated progressively outward from a stream, and more land area contributes flow to receiving waters. The area contributing overland flow increases as areas become saturated or the infiltration rate is exceeded by rainfall intensity (Horton 1937). This concept has been incorporated into the more complicated water quality models, particularly to develop storm hydrographs (Beven and Wood 1983, Troendle 1985, O'Loughlin 1986, Moore et al. 1988).

Given that the process of nutrient and sediment loading is inextricably linked to runoff, it follows that the area contributing runoff, either through subsurface or overland flow, places a boundary on the area that can contribute nutrients to receiving waters (Dunne et al. 1975, Novotny and Chesters 1989). Factors other than hydrologic characteristics also influence the extent of the nutrient-contributing area. Physical factors that influence sediment movement and, therefore, particulate phosphorus movement include slope angle and length of flow path to the receiving water (Wischmeier and Smith 1978). Soluble phosphorus movement and transformations across and within a landscape are influenced by several soil factors: soil $\mathrm{pH} ; \mathrm{Al}, \mathrm{Fe}, \mathrm{Mn}$, and $\mathrm{Ca}$ concentrations; percentage of organic matter; clay content; permeability; and depth of the A horizon (Brady 1974). 


\subsubsection{Process-based delivery modeling}

Process models use mathematical descriptions of the transport capacity of water to model sediment delivery (Knisel 1980, Beasley and Huggins 1982). These typically are sequentially run hydrologic and carrying capacity models or single equations resulting from combinations of hydrologic and carrying capacity equations. The most widely accepted mathematical expressions used in these models include stream power equations (Bagnold 1966, Yang 1972), and models that include a shear stress component (Foster and Meyer 1972). The models are run to determine the amount and velocity of flow. This is converted to a bedload-carrying capacity, which is compared with the amount of sediment of several particle size classes already in solution to determine if sediment is deposited or transported along a given length of flow. Nutrient transport is estimated using these models by assigning nutrient concentrations to the different particle size classes.

These process models, while providing valuable understanding of the processes driving nutrient and sediment delivery, have enjoyed only limited use outside the research community. The application of these models generally results in accurate estimates of sediment yield, but is less successful in predicting nutrient loading (Lee 1987). The development and testing of these models have provided a greater understanding of the processes and particularly of the specific variables important in successfully describing the processes (Bennett 1974, Walling 1983, Novotny and Chesters 1989). However, the complexity of the equations and the large volume of data required to calibrate and verify them have limited their use. Most water quality planners and managers turn to the empirical models.

Phillips (1989a, b) developed two theoretically based models of buffer strip efficiencies that use readily available data. These are based on Green-Ampt and Darcy's (Skaggs and Khaleel 1982) equations developed for hydrologic movement and Bagnold's stream power equation (Bagnold 1966), specifically, and results are based on comparing all buffers with an arbitrarily selected reference buffer with known conditions.

Hydraulic model

$$
\begin{gathered}
B_{b} / R_{r}=\left(n_{b} / n_{r}\right)^{0.6}\left(L_{b} / \mathrm{L}_{r}\right)^{2}\left(K_{b} / K_{r}\right)^{0.4}\left(s_{b} / s_{r}\right)^{-0.7}\left(C_{b} / C_{r}\right) \\
\text { Detention model } \\
B_{b} / R_{r}=\left(n_{b} / n_{r}\right)^{0.6}\left(L_{b} / L_{r}\right)^{0.4}\left(K_{b} / K_{r}\right)\left(s_{b} / s_{r}\right)^{-1.3}
\end{gathered}
$$


where

$B, b$ and $R, r$ refer to buffer and reference buffer conditions, respectively,

$$
\begin{array}{lll}
n & = & \text { Manning's roughness coefficient, } \\
L & = & \text { length across buffer }(\mathrm{m}), \\
K & = & \text { hydraulic conductivity, } \\
s & = & \text { sine of the slope angle relative to the } \\
\text { horizontal, }
\end{array}
$$

The hydraulic model was developed for elements for which delivery is directly proportional to energy of overland flow including sediment and other large particulates and adsorbed pollutants such as phosphorus and heavy metals. This equation was derived from a combination of Green-Ampt, Darcy's, and Bagnold's equations. The detention model was developed for elements for which delivery does not depend on kinetic energy of moving water but rather on interactions within the soil matrix and vegetation (e.g., nitıogen). This directly relates to how long a parcel of water is in contact with a buffer, hence the term detention model. Because all results are expressed relatively not absolutely to the reference buffer, the quantification of mass movement is difficult.

In a sensitivity analysis of these models, Phillips (1989a) found that buffer width was by far the most important variable for the detention model, explaining up to $81 \%$ of the variation in buffer strip efficiencies. Soil moisture capacity was less important, explaining $13 \%$ of the variation. For the hydraulic model, slope gradient and saturated hydraulic conductivity were the most important in explaining variation (66\% and $27 \%$, respectively). These results will be compared with those of the models developed in the analysis presented in this chapter. The problem remains, however, to quantify, in absolute terms, the amount of sediment and nutrient that is delivered to a water body and to be able to relate this to a source area.

\subsubsection{Empirical Delivery Models}

Typically, empirical models use delivery ratios to describe the overland flow transport component. These are represented as single values for entire watersheds and are almost exclusively associated with sediment delivery. This method has been driven by the widespread use of the USLE, which produces a potential yield value. The delivery ratio has been used to convert the potential yield to a prediction of sediment delivery. There have been a host of empirically derived delivery ratios of sediment transport. Walling (1983) reviewed the sediment delivery ratio problem and noted the wide variety of equations describing this process and the problems associated with each. Many of the models included an index of basin morphometry either as basin area (Mills 1985, Del Regno and Atkinson 1988), basin length (Reckhow et al 1989), and basin slope or some combination of these (Maner 1958, Williams and Berndt 1972, Williams 1977). Still others used drainage density as an index of average overland flow distance. Usually these delivery ratios are lumped; a single delivery ratio value is assigned to the entire watershed. 
There have been efforts to calculate delivery values on a distributed basis (Kling 1974, Shanholtz et al. 1988). Shanholtz et al. (1988) calculated delivery ratios in a distributed system with an equation that used length of flow path, land cover, and slope. They used average slope along the flow path, however, which is, in effect, a linear lumping procedure. Other research has focused on the temporal variations of delivery ratios. Piest et al. (1975), McGuinness et al. (1971), and Dickinson and Wall (1977, 1978) all demonstrated extreme variations in delivery ratios over the course of a year, even in the same basin. This can be explained, in part, by the variable source area concept in hydrology. Delivery during any event is linked to the amount of water transported from a point in the watershed to the outlet. The spatial and temporal distribution of overland flow, as described by a variable source area, controls delivery of water-borne pollutants.

\subsubsection{Vegetated filter strips}

A body of literature on vegetated filter strips (VFS), also referred to as buffer strips, is untapped but appropriate for addressing the development of overland delivery ratios for sediments and nutrients. This literature consists of data from controlled experiments that quantify amounts of sediment and nutrients trapped while traversing a plot and has been reviewed several times (Magette et al. 1989, U.S. EPA 1988). A compilation of references prepared by Williams and Lavey (1986) identified over 300 citations related to this field. These have generally been designed to answer questions about problems specific to the local area where the studies were performed. These studies varied in scale from test-tube analysis of nutrient transformations and releases from soil (Miller 1979, Cogger and Duxbury 1984, Johnson et al. 1986) to watershed-level studies covering hundreds of hectares (Karr and Schlosser 1977, 1978; Schlosser and Karr 1981a and b; Lowrance et al. 1983, 1984a, b; Lowrance et al. 1984; and Peterjohn and Correll 1984). While some efforts have synthesized watershed-level loading rescarch into export coefficients (Reckhow et al. 1980, Rast and Lee 1983, and Omernik 1977), little or no attempt has been made to synthesize the field- or plot-level research on sediment and nutrient movement. Additionally, since the SCS developed the USLE, there has been no nationally coordinated study designed to generate models applicable nationwide, the current Water Erosion Prediction Project (WEPP) excluded (Rawls and Foster 1987). The importance of the information that such an effort would provide is becoming more and more clear. While local research can provide information to develop and drive prediction models for areas where the research was performed, transporting a model to another region has proved difficult to impossible. Thus, a synthesis of existing research from across the country would provide useful information for developing nationally applicable NPS transport models.

The major problem with a literature synthesis of this nature is the comparability of existing data and results from varying study designs. For instance, it may not be valid to combine and compare results of physically controlled field plot studies of nutrient movement with results from a similar study performed along an uncontrolled transect in a watershed. Even without this issue, often the methods of measurement, actual parameters measured, and method of reporting results vary so much across studies that making sense of the data and results is nearly impossible. Developing techniques in meta-analysis offers some promise in solving this dilemma (Mann 1990). It appears, however, that this 
approach is somewhat controversial and needs additional methods development before it becomes widely accepted. Currently, the only way to perform a proper synthesis is to find a body of experiments with study designs similar enough to make the results comparable. Some of the studies from the VFS literature provide this body of work, thus allowing for such a synthesis.

The VFS literature covers a variety of loading conditions because buffer strips have been applied to many water quality problems. These include the following general areas: studies dealing with the effectiveness of VFS for primary and/or tertiary treatment of human and animal feedlot waste; studies on the effectiveness of VFS to reduce nutrients, sediments, and pesticide concentrations in runoff from agricultural lands; and studies to determine the effectiveness of VFS to reduce sediment delivery from harvested forest plots. Conditions in these studies run the gamut of possibilities in soil conditions, vegetation, nutrient-loading rates, rainfall rates and durations, and physical parameters such as slope and distance of travel. Although several reviews exist on VFS, none of them have resulted in specific conclusions because of varying conditions across studies (Magette et al. 1989, U.S. EPA 1988). These varying conditions are conducive to the development of a widely applicable model, however, the data limitations should be kept in mind.

The need to use the results of field or plot studies to develop distributed watershed NPS loading models has driven much of the recent work in VFS research. However, the focus usually has been toward application of local research to site-specific problems. Pressure to produce statewide guidelines for filter-strip widths has resulted in "rules of thumb" or "best guesses" to set standard widths (Roman and Good 1983, McCullough 1985, Budd et al. 1987, Phillips 1989a). More process-oriented efforts have produced models such as CREAMS (Knisel 1980), AGNPS (Young et al. 1989), and ANSWERS (Beasley and Huggins 1982). These models are being developed to allow distributed parameter modeling, but parameterization proves to be difficult for large geographic areas because of the type and amount of data needed to calibrate and verify the models for specific locations. Similar models need to be developed that use generally available or easily obtainable information such as vegetation cover, soil type, and characteristics found in the county soil surveys, slope and distance, and initial loading rates.

\subsubsection{Channel Flow Delivery}

The final component of the sediment- and nutrient-delivery problem is channel flow delivery. As with overland flow delivery, both process models and empirical models have been developed.

\subsubsection{Process-based Delivery Modeling}

The process-based models generally use the same equations for this process as they use for the overland flow process. In fact, most of the process-based delivery equations were developed for channel flow delivery and transformed into overland flow delivery equations (Novotny and Chesters 1989). Thus, these equations do a good job in 
predicting channel delivery. The problems associated with using these equations to model channel delivery are the same as when they are applied to overland flow delivery. They are complex and data intensive. Additionally, the channel form of these equations is applied only in cells identified as channel cells (Beasley and Huggins 1982). This means that the modeler must identify stream cells in the data base. Typically, stream cells are identified by blue-line streams from topographic maps of the U.S. Geological Survey (USGS). The blue-line streams represent perennial streams, however, and are not a true representation of stream channels during storm events. Some applications of these models have identified finer stream networks for channel routing, but this is difficult to accomplish over a large area (Knisel 1980). In either case, the stream network is assumed to be static during model runs, which is not a true representation of where channel flow occurs. A method to address this problem is presented in the section devoted to digital elevation model processing.

\subsubsection{Empirical Delivery Models}

One of the basic premises of stream morphology is Playfair's Law, which states that over a long time a natural stream must transport essentially all sediment delivered to it (Novotny and Chesters 1989). Leopold et al. (1964) concluded that floodplain aggredation is in equilibrium with floodplain degradation. This suggests that the average delivery ratio for channel sediments is essentially 1.0 (Novotny and Chesters 1989). Frickel et al. (1975) showed that most main channels and tributaries in the Piceance basin in Colorado did, in fact, have a sediment delivery ratio of 1.0. Therefore, for the purposes of this model, I assume that sediment delivery in stream channels is $100 \%$. Because nutrients are more easily transported, I also assume that the delivery of phosphorus and nitrogen in stream channels is $100 \%$.

\subsubsection{Stream Network Delineation}

Delineating stream networks that are relevant to storm- related delivery of sediments and nutrients is of critical importance in NPS modeling. Although several authors have suggested that the resolution of the stream network may affect model performance (Omernik et al. 1981, Engel et al. 1991, Hunsaker et al. 1991), little research has explored this question. A comparative study of small urban watersheds with and without storm sewers demonstrated how important it is, in NPS modeling, to identify the appropriate drainage network (Novotny et al. 1979). Novotny et al. (1979) showed that delivery ratios for sediment ranged from $1 \%$ for the unsewered watershed to $100 \%$ in the storm-sewered basin. This study illustrates how much error can be introduced to a distributed NPS model if the stream network is underestimated.

I used a technique based on identifying runoff contributing areas and delineating stream networks to provide easy manipulation of the stream network density. I used this tool to calibrate my model. Changing the stream network, where delivery is assumed to be $100 \%$, effectively changes the total flow path delivery ratio in each cell. This is precisely the type of calibration technique that Novotny and Chesters (1989) defined as a major research need for solving the sediment delivery problem. 
Contributing area delincation. As suggested earlier, variable source area is a critical concept in hydrologic and water quality modeling. To date, three general methods for determining runoff contributing areas have been applied with varying degrees of success. These methods have been based upon soil characteristics, topography, and vegetation. Betson and Marius (1969) presented a method to delineate contributing areas based on soil characteristics such as depth to impermeable layer, infiltration rates, and proximity to water. Engman and Rogoski (1974) quantified these factors, along with rainfall intensity, to successfully delineate contributing areas and generate stor. hydrographs that closely matched observed events. Dunne et al. (1975) mapped soil color (e.g., areas of gleyed soils) to identify areas that experience seasonal saturation and, therefore, are likely to be contributing areas.

Numerical analysis of topography has provided another method to estimate contributing areas (Beven and Kirkby 1979, Heerdegen and Beran 1982, Beven and Wood 1983, and O'Loughlin 1986). These studies used areas with convergent flow paths and retarding overland slopes to delineate contributing areas. Beven and Wood (1983) and O'Loughlin (1986) combined several soil attributes to the topographic analysis to further refine the estimates of contributing areas. Beven and Kirkby (1979) developed a topologic model (TOPMODEL) that determines the area drained by a unit area of contour as a measure of saturation.

The third method to estimate runoff contributing areas used vegetation as the identifier (Winkler and Rothwell 1983). Vegetation was used as a surrogate for both soil attributes and topographic characteristics. The plant associations used to identify contributing areas were associated with wet riparian habitats found in low-lying areas with seasonally saturated soils. Although hydrographs based on contributing areas identified by vegetation poorly resembled the actual hydrographs, the refining of this technique may prove useful when combined with remotely sensed data.

Digital elevation model processing to delineate stream networks. A different method will be used in the model developed here. Jensen and Domingue (1988) developed a set of watershed process models that extract hydrologically relevant information from digital elevation models (DEMs). These models include direction of flow, slope, watershed delineation, and a program called COUNT, which calculates the watershed area of each cell in a DEM as the number of cells that flow into each cell. Stream networks were identified by selecting thresholds from the COUNT output file and demonstrated a $98 \%$ match with blue-line streams from USGS 7.5-min quadrangles (Jensen and Domingue 1988). Stream network densities can be increased by reducing the threshold value in the COUNT file. This assumes that the higher the COUNT value, the more likely a cell experiences overland flow. As the threshold value is reduced, the stream network expands and becomes more irregular as areas of potential overland flow are identified. This parallels the process of source area expansion during a storm event. The DEM approach is very similar to the TOPMODEL approach; however, it does not account for slope as does TOPMODEL.

Cells within the stream network, identified with this technique, are assumed to be channel cells and are assigned delivery ratio values of 1.0. The model is calibrated by overlaying the stream network onto the landscape-based delivery ratio file and comparing 
result the observed load estimate with the observed load. Once the model is calibrated, maps of contributing areas for each pollutant can be generated and management alternatives can be evaluated.

\subsubsection{Hydrologic Flow Path Delivery Ratios}

The previous section established a method of estimating detachment and delivery of sediments and nutrients for individual cells in a distributed model. To define a method of sequentially accumulating the delivery ratios to account for the loss of mass during transport along the entire flow path of each cell, I used concepts of DEM processing tc delineate flow paths and accumulate delivery ratios.

\subsubsection{Flow Path Determination}

Determination of hydrologic flow paths from DEMs is not a simple problem (Beven et al. 1988). Several approaches have been used over the past several years (Band 1986, O'Loughlin 1986). More recent developments in DEM analysis provide a tool to identify flow paths for every cell in a rasterized terrain model (Jensen and Domingue 1988). Flow path is determined for each cell by comparing elevations in the eight surrounding cells. A number is assigned to each cell indicating direction of flow. This information is used to determine flow path. Starting at a seed cell, a program can step up or down the watershed by following the direction of flow values. As the program traverses the surface, any type of algebraic manipulations can by made with values in coincidental surfaces (Tomlin 1990). This is how I sequentially accumulated the cell delivery ratios into total flow path delivery ratios.

\subsubsection{Sequential Accumulation of Delivery Ratios}

Linking flow path information with a delivery ratio surface provides a refined tool to model nutrient and sediment load to a receiving water body. Initially, each cell has a delivery ratio. As the model runs, it sequentially multiplies the cell delivery ratios of each cell along the flow path to get total flow path delivery ratios (Fig. 1.2).

Multiplying the total flow path delivery ratios by the potential loads from each cell results in total load delivered from each cell (Fig. 1.3). This provides an estimation of the total load delivery to the outlet of the watershed and a map of the load contributing areas.

\subsection{HYPOTHESES}

Six hypotheses were specifically tested to meet the objectives of the model. First, to establish the validity of using nutrient export coefficients and the USLE output as potential yield estimates, I must show that using these estimates without applying delivery ratios would result in extremely high estimates of annual loads. The first hypothesis is directed at showing that this is true: 


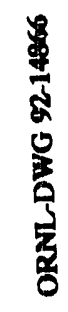

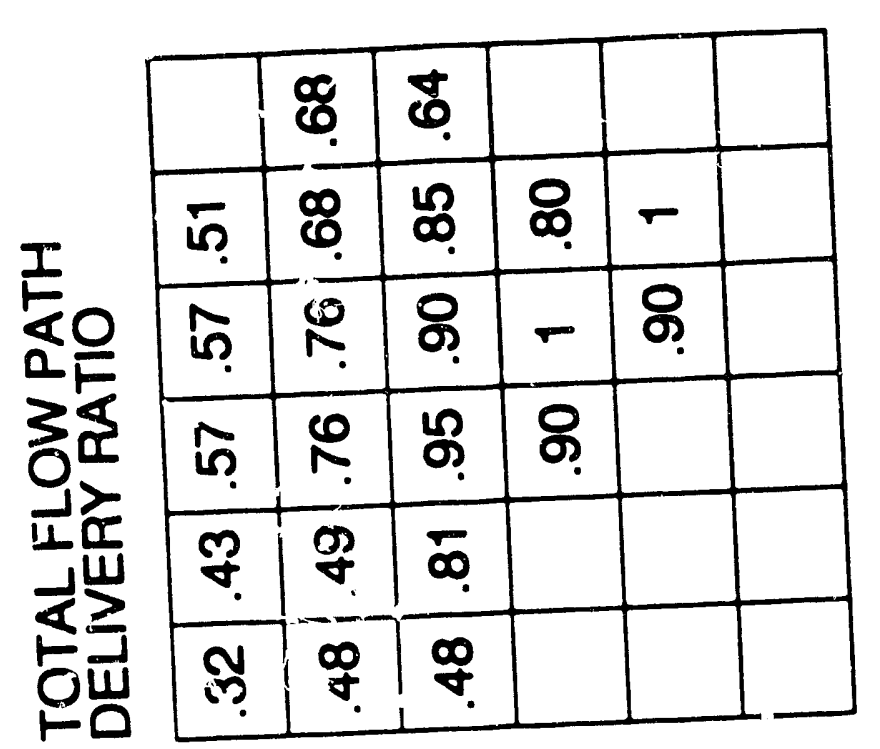

ธิ

동 돈

凑

है

氜

는

喜

3 व

息

홍

过

氙

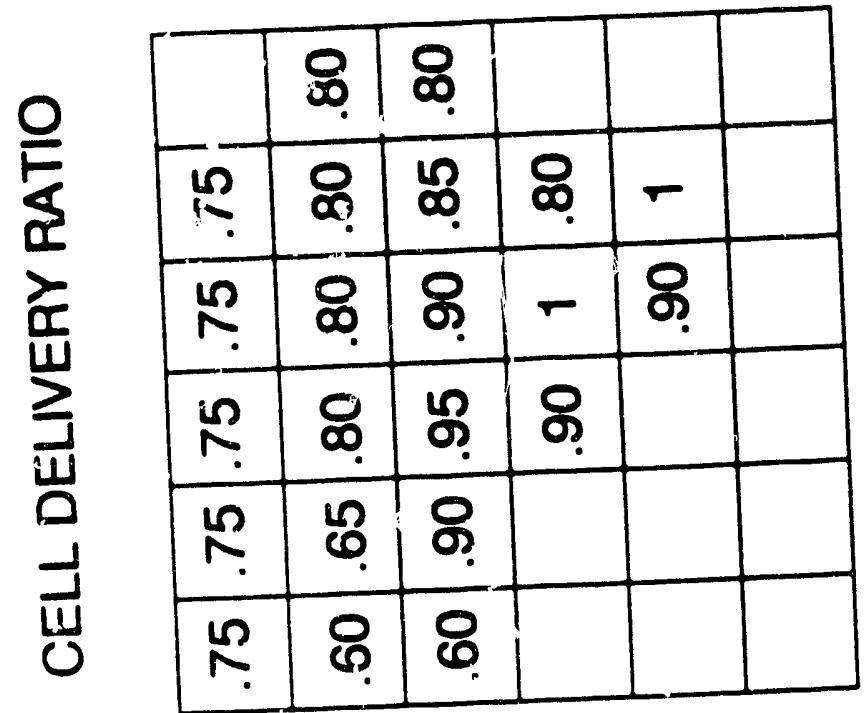

㐘

है

홍

을

올

기

. 들

व

$\overline{8}$

넝

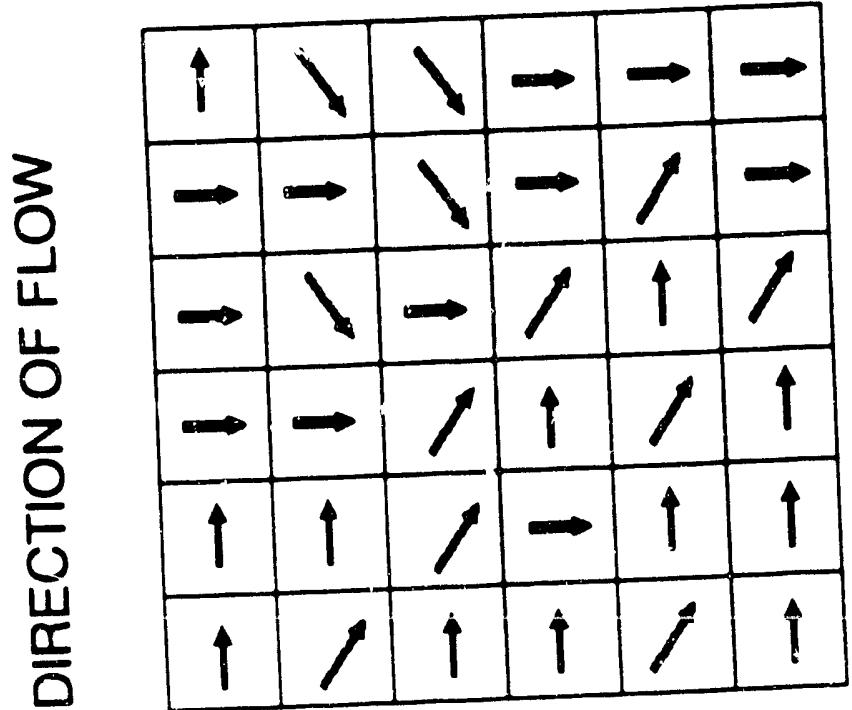

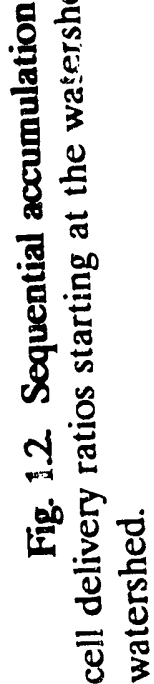




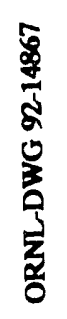

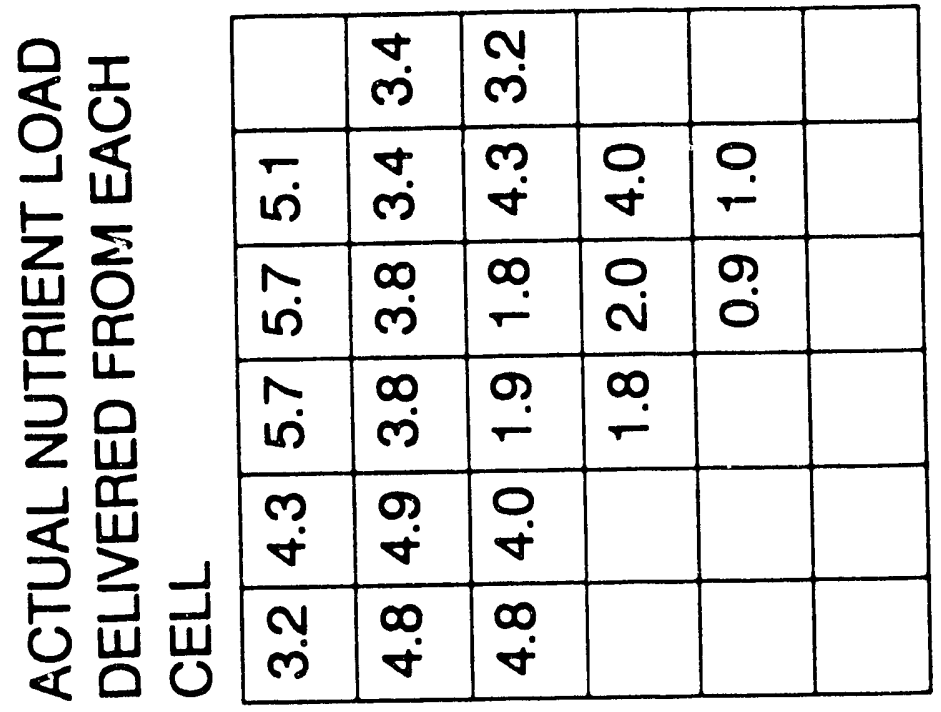

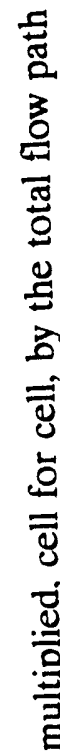

\begin{tabular}{|c|c|c|c|c|}
\hline & $\underset{0}{\infty}$ & రి & & \\
\hline $\bar{n}$ & @ & $\stackrel{1}{\infty}$ & வ & $r$ \\
\hline ? & $\stackrel{0}{N}$ & คి & $r$ & कి \\
\hline$\hat{n}$ & $\stackrel{\infty}{N}$ & ใุ & ᄋి & \\
\hline P. & g. & $\bar{\infty}$ & & \\
\hline กิ & $\stackrel{\infty}{+}$ & $\stackrel{\infty}{+}$ & & \\
\hline
\end{tabular}

․․

ช్

总

皇

\begin{tabular}{ll|l|l|l|l|l|}
\hline & 0 & $n$ & $n$ & $n$ & $n$ & $n$ \\
\hline
\end{tabular}

包

灵

휸

4

魚旁

$\equiv \frac{1}{2}$

\begin{tabular}{|c|c|c|c|c|c|}
\hline$\underline{0}$ & ת) & ما & ما & $r$ & $\sigma$ \\
\hline$\stackrel{0}{\circ}$ & ص & $\mathbf{N}$ & $\boldsymbol{N}$ & $r$ & $r$ \\
\hline$\stackrel{?}{\circ}$ & ת) & $\mathbf{N}$ & $\mathbf{N}$ & $N$ & $\mathbf{N}$ \\
\hline$\stackrel{0}{r}$ & $\stackrel{\varrho}{\circ}$ & תا & ما & $N$ & $N$ \\
\hline$\stackrel{0}{2}$ & $?$ & 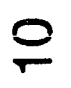 & $?$ & 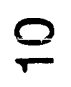 & 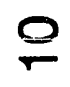 \\
\hline
\end{tabular}


$\mathrm{H}_{\mathrm{o}}$ 1: There is no difference between loads estimated from potential loads alone (without applying delivery ratios) and the observed loads. A onetailed Paired Student's t-test will be used to test this. The testing of this hypothesis represents an attempt to justify using delivery ratios with export coefficients. It is expected that export coefficients alone will grossly overestimate sediment and nutrient loading.

Next, I want to demonstrate that the model works. This is accomplished by comparing model estimates of annual loads with observed annual loads.

$\mathrm{H}_{\mathrm{o}}$ 2: There is no difference between observed annualloads and model predictions of total phosphorus, total nitrogen, and total suspended solids load. Model output will be compared with observed loads using two-tailed paired Student's t-tests.

I also want to demonstrate (1) the importance of stream network density to NPS model output, (2) the utility of stream network density as a calibration tool, and (3) the use of the COUNT program to do this. These three objectives can initially be demonstrated during the calibration step. If the model calibrates using this technique, all three of these goals will be met. Another test is whether or not the model calibrates to the same COUNT value for each pollutant. This is accomplished with the following hypothesis:

$\mathrm{H}_{\mathrm{o}}$ 3: There is no difference in calibration COUNT values for each water quality parameter in each watershed. Again, these will be qualitatively compared.

Additionally, assuming that the model provides accurate estimates of annual loads, different COUNT thresholds at calibration points for different physiographic regions would demonstrate the sensitivity of the model and the COUNT method to different types of watersheds. This would provide a measure of the transportability of the model to other regions of the country. The following hypothesis is directed at testing this concept:

$\mathrm{H}_{\mathrm{o}}$ 4: There is no difference in the calibration COUNT value in the three physiographic regions of the study area. COUNT threshold values for calibrations from watersheds from the three regions will be qualitatively compared. 
It is important for NPS management to know if the extent of load-contributing areas is different for various pollutants. I used the model to test this with the following hypothesis:

$\mathrm{H}_{\mathrm{o}}$ 5: There is no difference in total contributing area from watersheds in each of the three regions for total phosphorus, total nitrogen, and total suspended solids. This will be tested using a two-way analysis-of-variance test.

I also test the accuracy of the model with respect to watershed size to further evaluate the applicability of

the model. This is an attempt to identify limits of the model application relative to watershed size.

$\mathrm{H}_{\mathrm{o}}$ 6: There is no correlation between watershed size and the percent difference between the estimated load and the observed load. This test will be accomplished by analyzing the trends in model error with respect to watershed size. 


\section{METHODS}

\section{WATERSHED DESCRIPTION}

The Lake Ray Roberts drainage basin is located $16 \mathrm{~km}$ north of Denton, Texas (Fig. 2.1). It occupies 179,821 ha (72,773 acres) and spans four Texas counties: Cooke, Denton, Grayson, and Montague (Fig. 2.2). The lake was dammed, and filling began in 1987. Because the dam is slightly below the confluence of the Elm Fork of the Trinity River, flowing from the west, and Isle du Bois Creek, flowing from the east, it forms a bifurcated reservoir. The drainage basins of each river system are quite different in morphometry, land use, and soil type (Fig. 2.3 and 2.4; Tables 2.1 and 2.2). Each arm of the lake is expected to be influenced both hydrologically and chemically by the basin of each separate river. This study subdivides these two basins into 12 watersheds, 5 in the Elm Fork River system and 7 in the Isle du Bois River system (Fig. 2.5).

\subsubsection{Physiographic Regions Within Ray Roberts Watershed}

The Ray Roberts basin includes three physiographic regions: Grand Prairie, Eastern Cross Timbers, and Blackland Prairie (Fig. 2.6). The Elm Fork of the Trinity River is almost entirely within the Grand Prairie region. Soils in this region are dark, slightly alkaline, and relatively high in clay and organic content. Upland soils are dark and of variable depth, with stony calcareous clays. Bottomland soils are reddish-brown to dark-gray clay loams and clays formed from alluvium deposits. The dominant upland vegetation is big bluestem (Andropogon gerardi), and bottomland vegetation is a highly diverse mosphytic forest of hardwoods. The terrain is relatively level to slightly undulating. Steep slopes occur immediately adjacent to streams. The region is underlain with alternating layers of shales and limestones several hundred feet thick.

The central portion of the Ray Roberts drainage basin encompasses the Eastern Cross Timbers region. This area is characterized by slightly acidic, sandy loams with moderate-to-high infiltration rates. The soils are reddish, light-brown and gray. This area has a characteristically rolling topography determined by the Woodbine geologic formation. Outcrops of the Woodbine geologic formation occur throughout the area and are characterized by post oak (Ouercus stellata) and black-jack oak (O. marilandica). River bottoms are lined with elms (Ulmaceac), green ash (Fraxinus pennsylvanica), pecan (Carya illinoinensis), and eastern cottonwood (populus deltoides).

The eastern part of th Ray Roberts watershed encompasses the Blackland Prairie region. Soils are gray-brown calcareous clays. The region is extremely flat and is underlain by the Eagleford shales and other related chalk formations. The dominant vegetation is bluestem grasses (A. gerardi and A. Furcatus.

Several watersheds were delineated within each region (Fig. 2.5). These watersheds were defined by water-quality sampling stations from which data were 


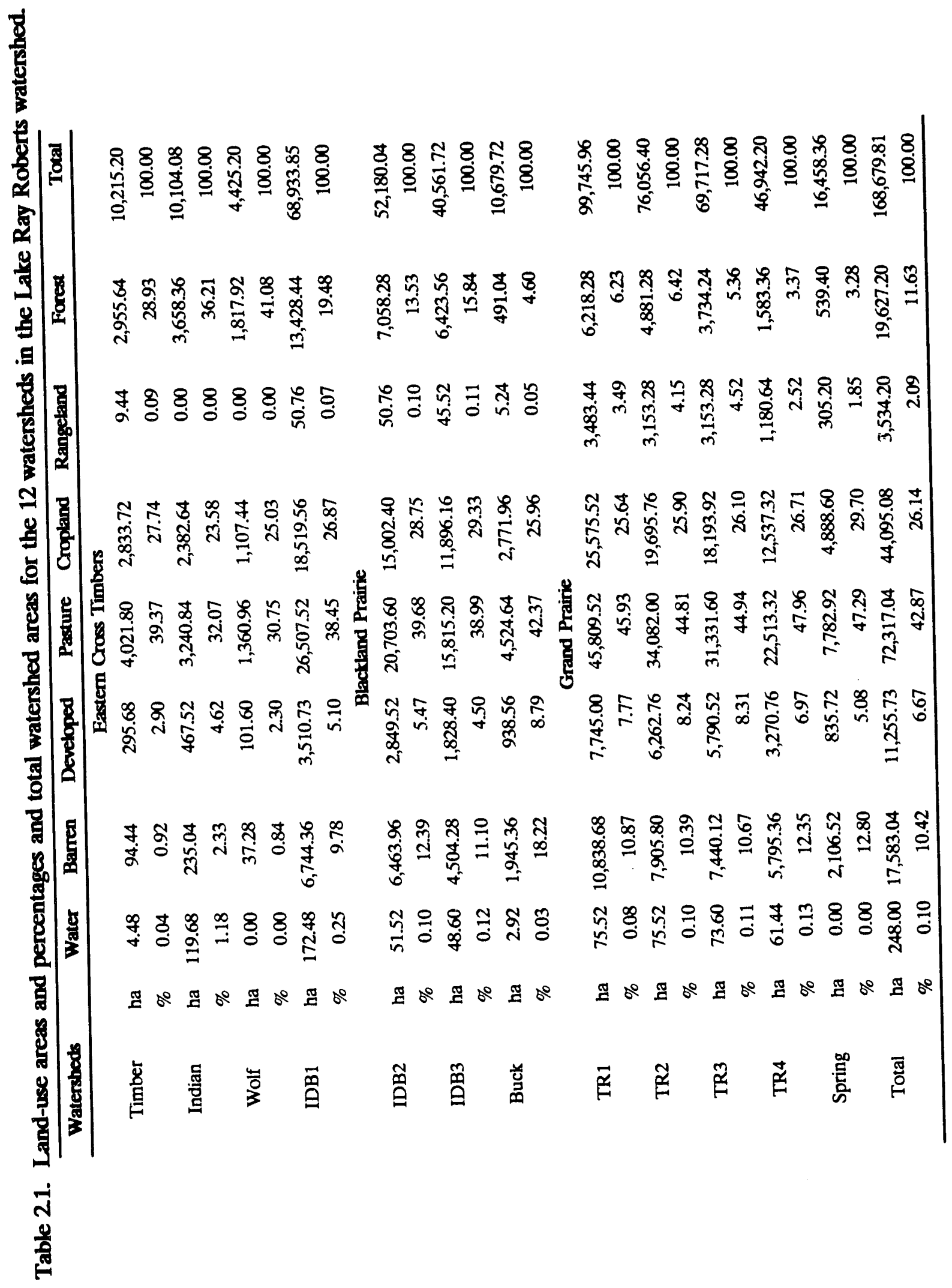




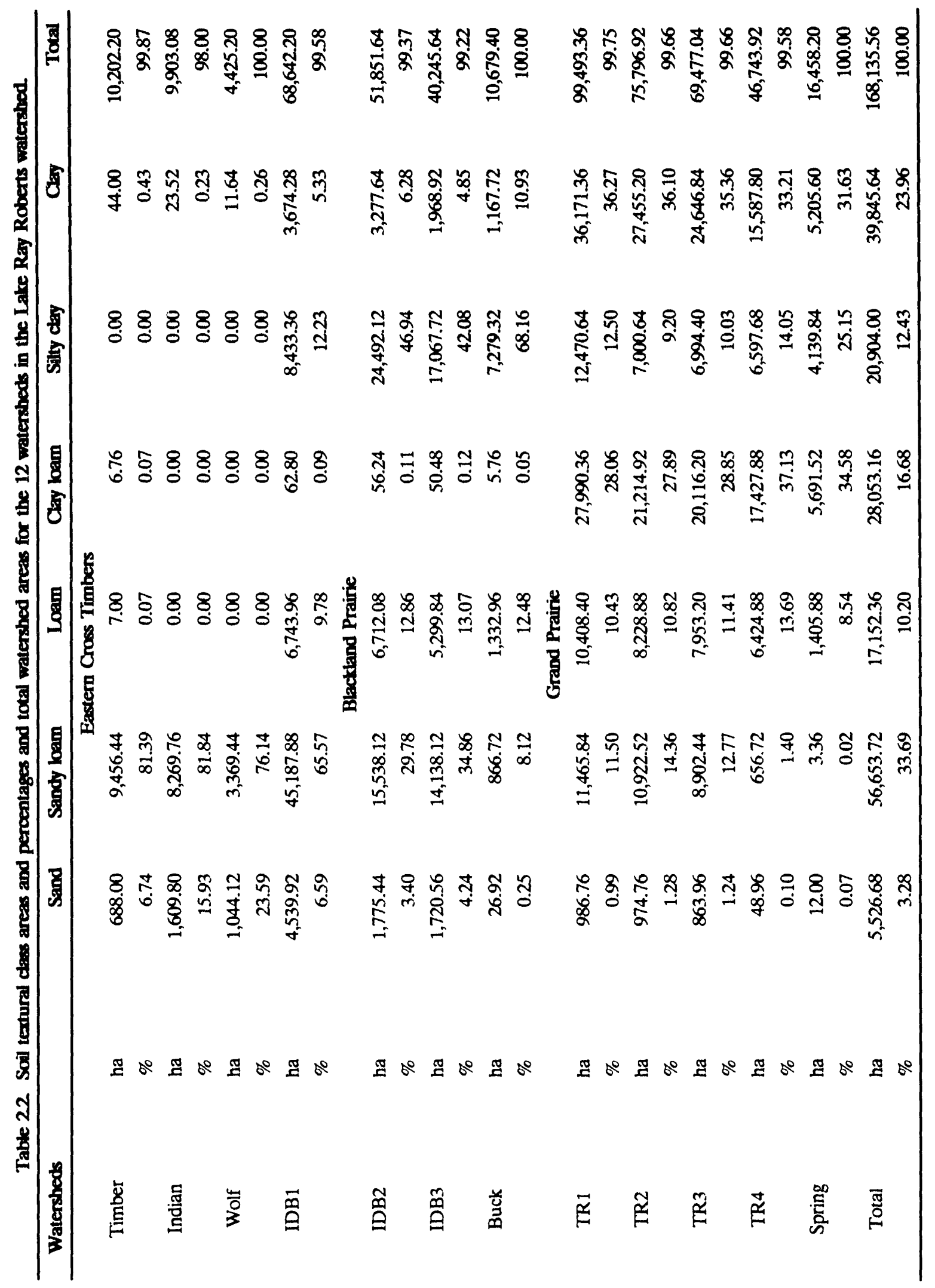




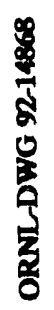

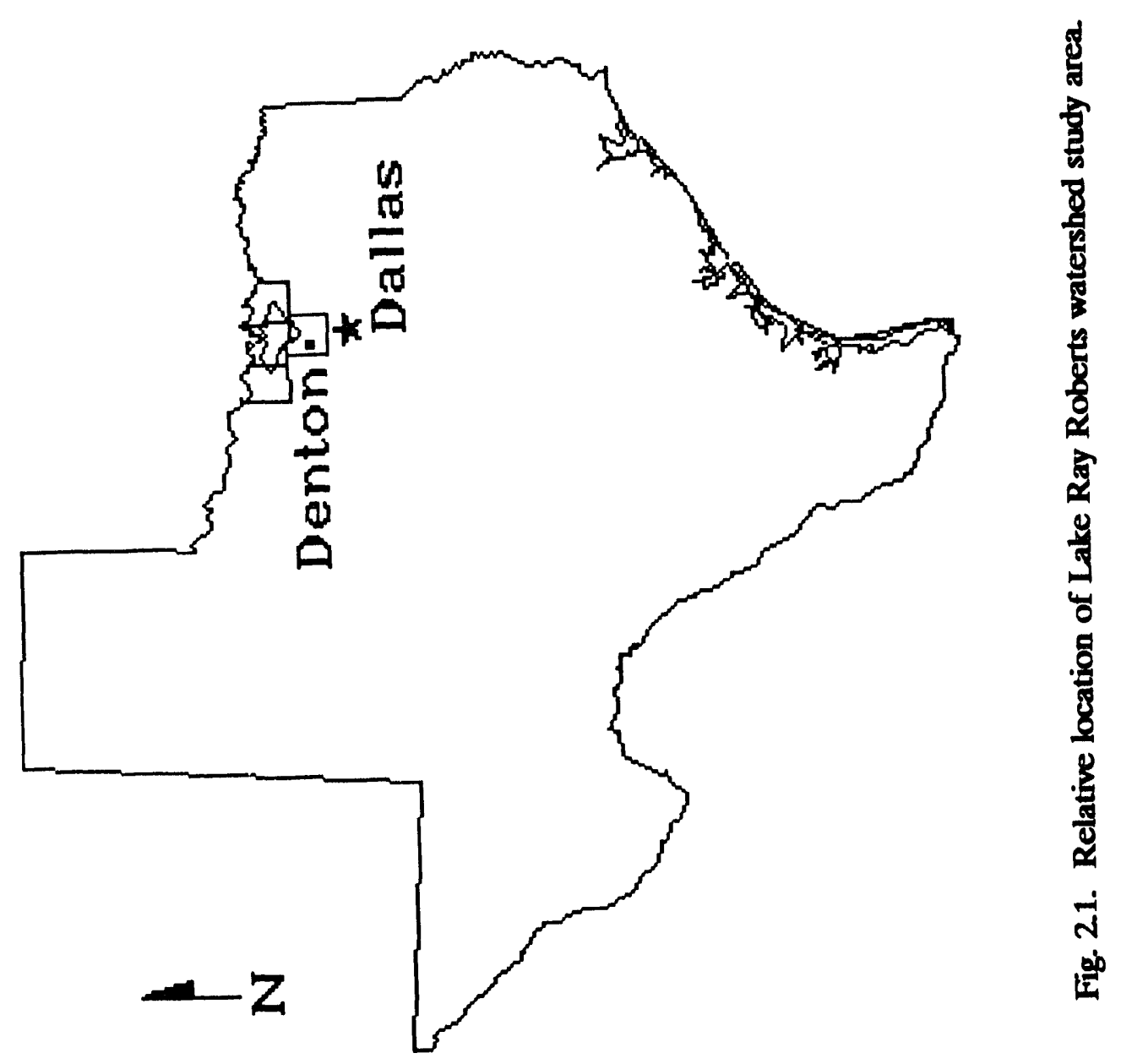


8
$\frac{8}{3}$
5
5
$\frac{3}{3}$
0

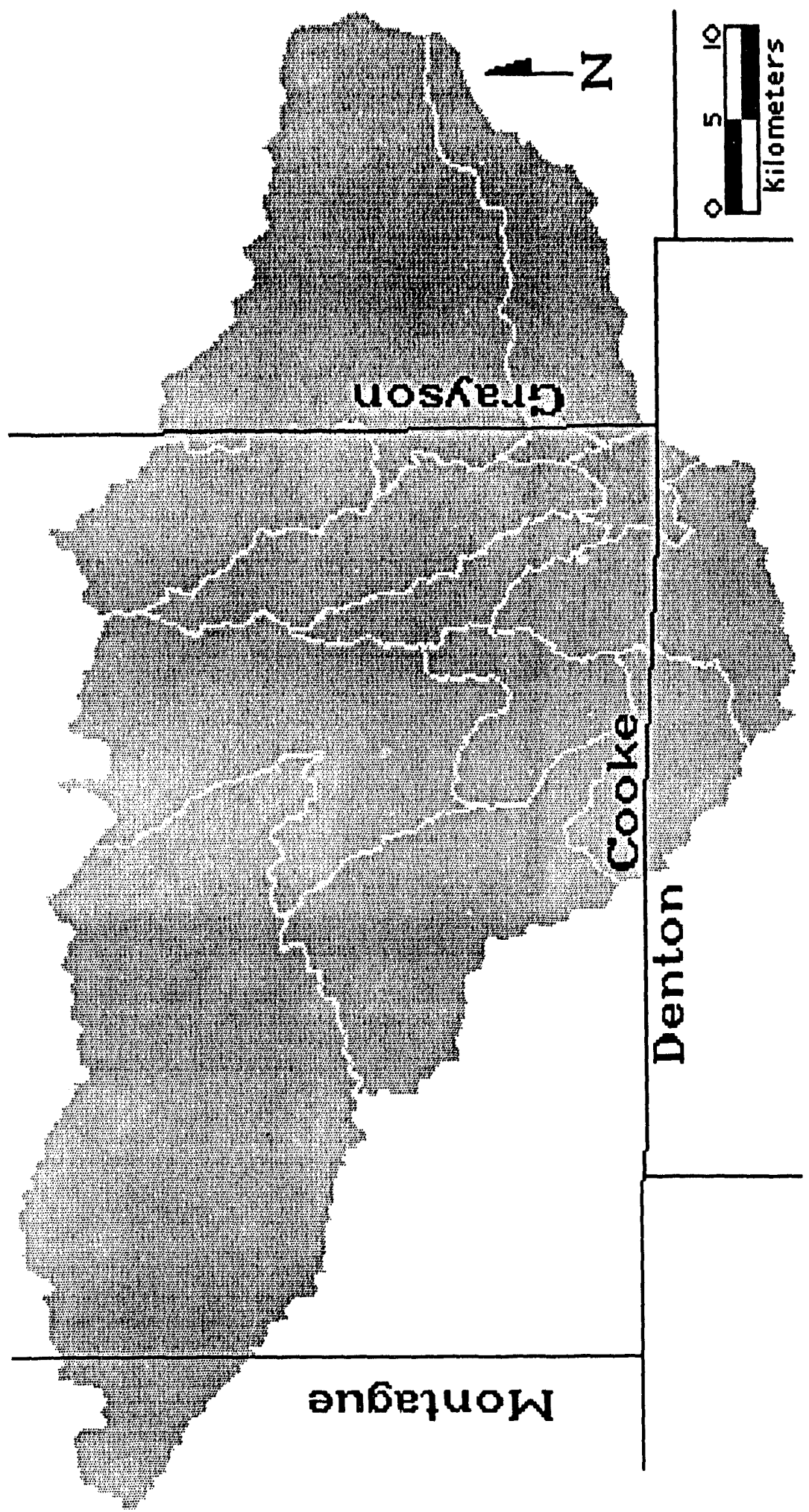


8
0
2
0
0
$\frac{1}{3}$
$\frac{1}{3}$
0
0

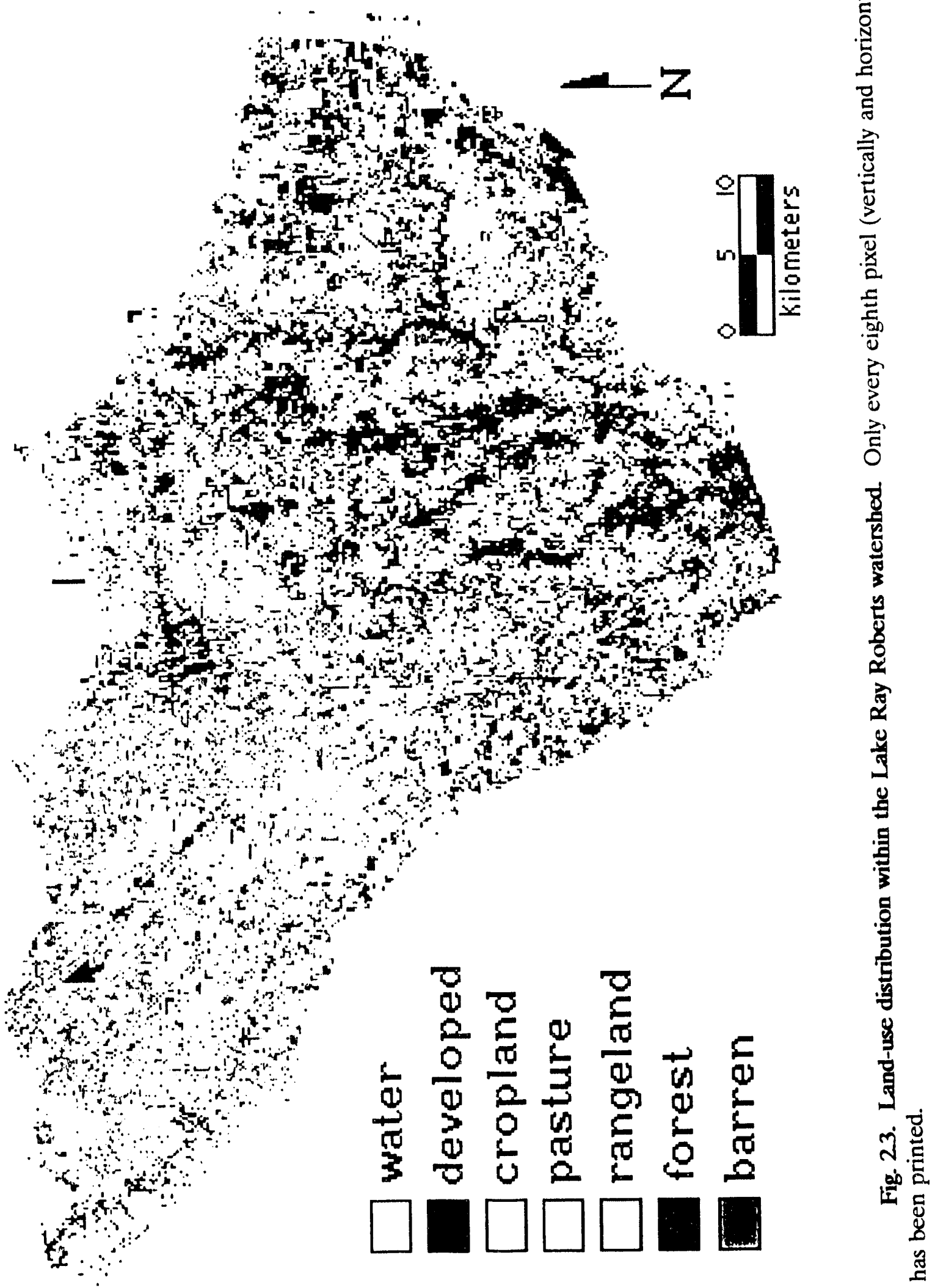


5
$\frac{1}{2}$
0
0
0
0

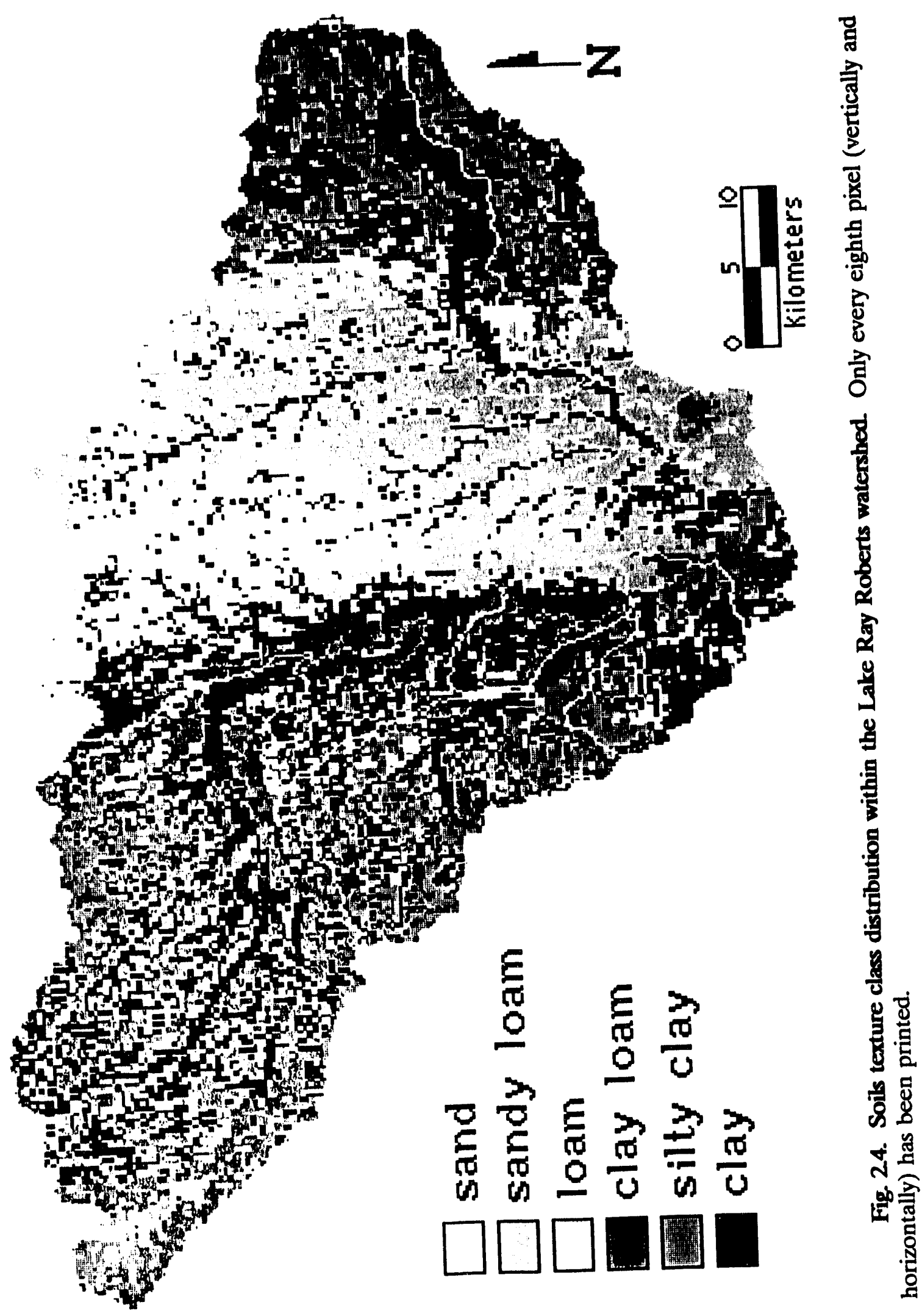




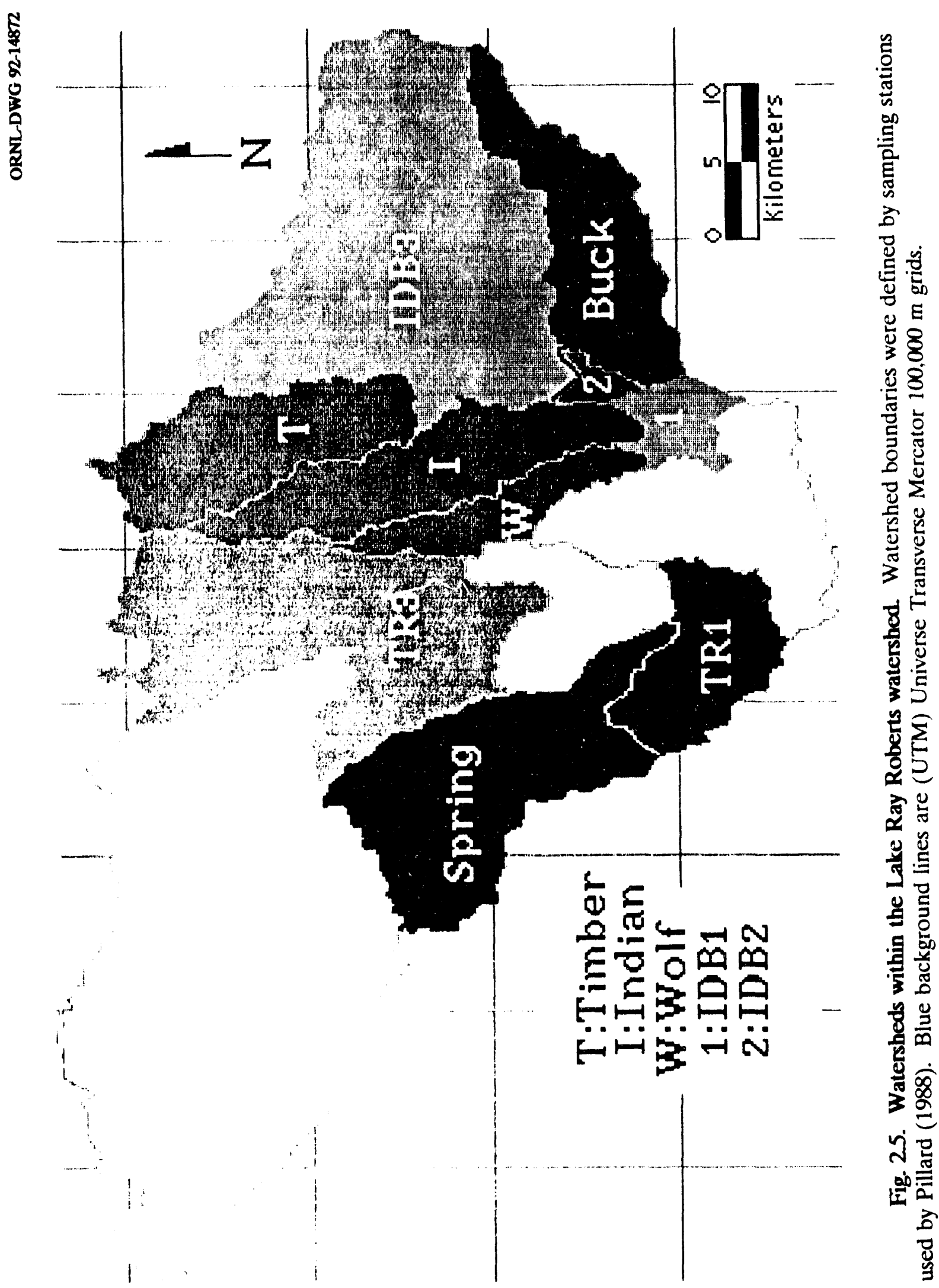


5
$\frac{5}{3}$
0
$\frac{3}{3}$
$\frac{3}{8}$

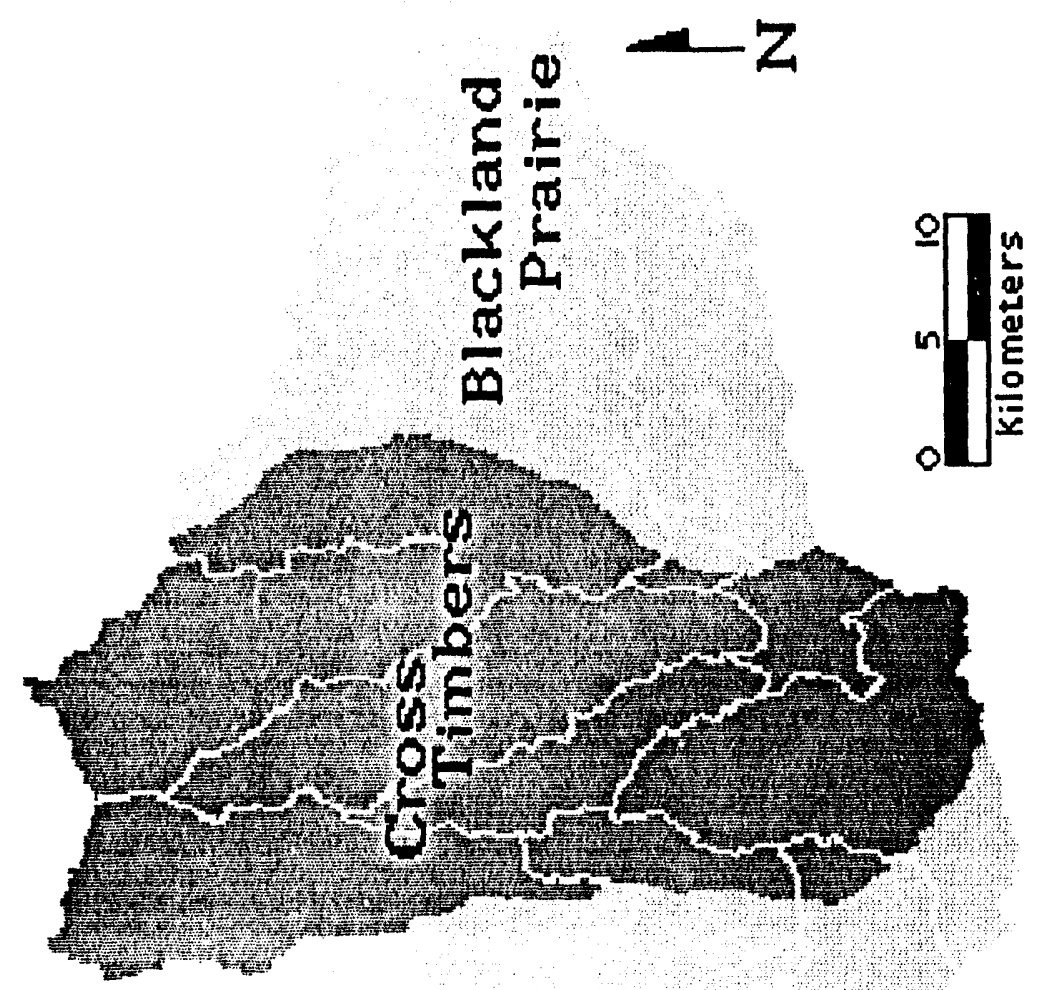

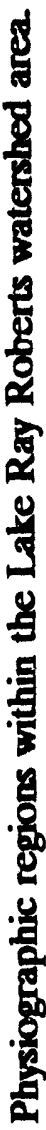

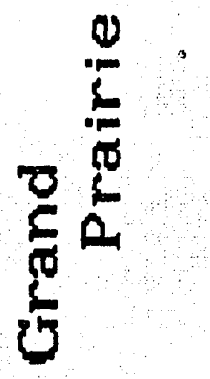

ㄱ.

ab 
available. The Elm Fork of the Trinity River was divided into five watersheds-identified from here on as TR1, TR2, TR3, TR4, and Spring Creek. These are nested watersheds, and TR4 flows into TR3, which flows into TR2, which in turn flows into TR1. Spring Creek flows directly into the TR1 watershed. All these watersheds drain mostly from the Grand Prairie region. The eastern edges of TR3, TR2, and TR1 drain the west slope of the Cross Timbers region. These are the largest watersheds in the study area, ranging from 16,458 ha (6,660 acres) for Spring Creck to 99,745 ha (40,366 acres) for the TR1 watershed. Three watersheds drain exclusively from the Cross Timbers region. Timber, Indian, and Wolf creeks all drain directly from the Cross Timbers region into the Isle du Bois Creek system. These are the smallest watersheds in the data set, ranging from 4,425 ha (1,791 acres) for the Wolf Creek watershed to 10,215 ha $(4,134$ acres) for the Timber Creek watershed.

The Buck Creek watershed drains the Blackland Prairie region and encompasses 10,215 ha (4,322 acres). Three other watersheds, IDB1, IDB2, and IDB3 drain both the Cross Timbers and Blackland regions. IDB3 includes the Timber Creek watershed, draining the Cross Timbers region, and much of the Blackland Prairie region. IDB3 flows into IDB2, which also includes the Buck Creek watershed. IDB1 has a total area of 68,933 ha (27,897 acres) and accumulates flow from IDB2, and Indian, and Wolf creeks and respresents the entire Isle du Bois basin.

\subsubsection{Climate}

The climate in the Ray Roberts watershed area is typical of north Texas. Average annual rainfall is around $84 \mathrm{~cm}$ (33 in.) uniformly distributed throughout the year, and a slight peak occurs during the spring months [U.S. Department of Agriculture (USDA) 1979]. Sixty percent of the rainfall occurs between April and September. This period is the growing season for most crops in the area (USDA 1980a). Thunderstorms occur on 50 days each year, mostly during the spring months. The highest 1-day rainfall event for the period between 1951 and 1976 was $14 \mathrm{~cm}$ (36 in) recorded at Gainesville. Average daily temperatures range from $6.67^{\circ} \mathrm{C}\left(44^{\circ}\right)$ in the winter to $27.78^{\circ} \mathrm{C}\left(82^{\circ} \mathrm{F}\right)$ in the summer.

\subsection{WATER QUALITY DATA}

\subsubsection{Observed Flow and Chemistry}

The water quality data for this study were obtained from the University of North Texas (Pillard 1988) and were collected biweekly from May 1985 through 1986 at the 12 sampling sites that define the watersheds in this study. The water quality parameters used in this study are concentrations of total phosphorus, total nitrogen, and total suspended solids and instantaneous flow velocity. Methods of analysis are provided by Pillard (1988). 


\subsection{Calculation of Observed Annual Loads}

Total mass loading observed for each pollutant was determined by multiplying the measured concentration by the flow for the same date and then multiplying the number of days for the period around each sampling date to get total loads for that sampling period. Period total loads were then summed to get annual mass load.

Several problems were encountered with this data set. First, total nitrogen was not measured until November 1985. Therefore, the water year used for this analysis ran from the end of October 1985 to the end of October 1986. Second, several watersheds do not have a complete data record. In some instances this is because there was no flow. In the case of Wolf Creek, the stream was not added to the sampling design until the spring of 1986. Observed values, therefore, are expected to be somewhat lower than the actual loads in Wolf Creek and may have impact on model performance in this watershed.

\subsection{SPATIAL DATA}

The spatial data base consisted of multiple layers, including land use/land cover, soils, roads, streams, watershed boundaries, elevations, and water-quality monitoring station locations. These data layers were used to create additional layers for modeling. The data layers came from various sources and were compiled into one georeferenced data set. Although each data layer originated in various and differing resolutions, the delivery ratio modeling, which generated regression equations, dictated a resolution of $20 \mathrm{~m}$. It is not valid ti) use regression equations with input data outside the range of data from which they were developed. The delivery ratio models were developed from data with an uppr $\mathrm{r}$ limit of $30 \mathrm{~m}$ for flow distance. A $20 \mathrm{~m}$ cell allows for diagonal flow to be modeled and still be within the limits of the model. The total area of the rectangle that encompasses the Lake Ray Roberts watershed is $3,476 \mathrm{~km}^{2}$. The dimensions of the array at $20 \mathrm{~m}$ resolution is 4,068 columns by 2,136 rows. This results in an image with $8,689,248$ cells. This array spans $\sim 81 \mathrm{~km}$ cast to west and $43 \mathrm{~km}$ north to south. The following section provides a description of the source data and of the processing required to prepare them for use in the model.

\subsubsection{Land Use/Land Cover}

Land use/land cover data were obtained from two sources. The Center for Remote Sensing and Land Use Analyses (CRSLA) at the University of North Texas (UNT) provided a classified 1986 Landsat multispectral sensor (MSS) coverage for the Ray Roberts watershed (Anderson et al. 1976). The watershed outline used by CRSLA was digitized from a low-resolution map, and some of the area actually in the watershed $(\sim \%)$ was not included in this file. The original unclipped MSS data were not readily available; therefore, additional data were obtained from the Soil Conservation Service (SES) National Cartugraphic Center in Fort Worth, Texas. The SCS land-use data came from luw-ievel acrial photographs taken in 1976 and were classified at a lower resolution $(250 \mathrm{~m})$ than the MSS ciata. Because of the coincidence in time with the water quality data and the higher resolution coverage, the MSS data layer was used as the main data 
set, and the SCS data layer was used to fill the $3 \%$ of the watershed where MSS data were missing.

The 80-m resolution MSS data file was classified by the CRSLA into eight land use/land cover categories: water, commercial, residential, industrial-transportation, agricultural, rangeland, barren land, and forest. The majority of the barren land is made up of fallow fields; however, this area also includes the site where excavation activity occurred near the Ray Roberts Dam (DelRegno and Atkinson 1988). The data were loaded into the IDRISI ${ }^{\circledR}$ GIS (Eastman 1990), which was used to resample the data to 20-m resolution (resampling was required for the modeling exercise and not meant to indicate that the data are accurate to $20 \mathrm{~m}$ ). To do this, IDRISI simply copies the value of each cell into an additional 4 rows and columns; thus, there are 16 cells with the same data value where there used to be 1 cell.

The land-use data from the SCS were from the Map Image Analysis and Display (MIADS) data base. This was une of the first raster GIS data bases to be created in the United States. The intent was to provide national coverage of county-level soils data. Although very little of the data base for the United States was ever finished, most of the county soil surveys for Texas were completed by using low-level aerial photographs. A giid with points $250 \mathrm{~m}$ apart was laid over the photographs, and a land-use type was recorded for each point. This represents the land use in the $250-\mathrm{m}^{2}$ area around that point. The data were classified into $\sim 80$ possible categories. The MIADS data base is available on a county by county basis. Files for Cooke, Denton, Grayson, and Montague counties were obtained and converted into IDRISI format. IDRISI was used to concatenate the four files into one file. The data were then resampled to a resolution of $20 \mathrm{~m}$.

Both land use/land cover files were georectified using the road network as control points. The road network provided points and lines throughout the watershed, and each of the two land use/land cover files had recognizable road systems. With both files in the same absolute position, the MSS file was overlaid onto the SCS file using the IDRISI OVERLAY command, and values in the MSS file were given precedence except where data were missing.

Once the combined data set was created, the two classification schemes were reduced into one, thus leaving the following categories: commercial/residential, industrial/transportation, water, cropland, pasture (maintained), rangeland (natural), forest, and barren land. Finally, the land use file was clipped to remove values outside the Lake Ray Roberts watershed (Fig. 2.3). The commercial/residential and industrial/transportation categories were reduced to one category, developed, for mapping purposes.

\subsubsection{Soils}

The soils GIS data layer was created entirely from the MIADS data set. Classification resolution is the same as the soil survey polygons in the county surveys. The MIADS soils data base was created using the same procedure as for the land use/land usver data layer. A 250 -m grid was laid over the photographs, and points were sampled 
for soil types and recorded to represent the soil type in the $250 \mathrm{~m}^{2}$ area surrounding that point. Soil files for each county were loaded into IDRISI and concatenated into one file. This file was resampled and georectified following the same manipulations used for the MIADS land use/land cover files. There were 105 soil types in the Ray Roberts watershed area. Soil attributes used in the models were identified for each soil from the county soil surveys: mean particle diameter, permeability, and the erosion K-factor used in the USLE (Appendix A) (USDA 1978, 1979, 1980a, 1980b). For permeability, the low value in the range reported in the soil survey table was used. Mean particle diameter was obtained using Table 3.1 in Novotnoy and Chesters (1981) and the soil texture description in the soil surveys. Soil attribute data were entered into a spreadsheet data base for use later in the analysis. A map of soil textural classes for the entire Ray Roberts Watershed illustrates the distinct differences among the three physiographic regions (Fig. 2.4).

\subsubsection{Road Network}

Locations of primary and secondary roads were digitized from a USGS $1: 250,000$ topographic map of the Shermann Quadrangle using ARC/NFO (ESRI 1987) (Fig. 2.7). These were edited and cleaned in ARCEDIT, and the files were converted into ASCII format for IDRISI processing. The vector files were used in IDRISI to georectify the land use and soils coverages as described earlier. The road file was then rasterized and overlaid onto the land use/land cover file to provide additional information on road location. Only primary and secondary roads were digitized because these are at least $20 \mathrm{~m}$ across, if not more; other roads are seldom $20 \mathrm{~m}$ wide.

\subsubsection{Watersheds, Streams, and Elevation Contours}

Watershed boundaries, streams, and elevation contours were digitized from 1:24,000 USGS quadrangle maps because these were the highest resolution maps available. The Ray Roberts watershed intersects or completely encompasses 21 map sheets (Fig. 2.8). These maps were obtained from the Texas Natural Resource Information Service (TNRIS). 
$\frac{1}{3}$
$\frac{1}{2}$
0
$\frac{2}{3}$
$\frac{2}{0}$

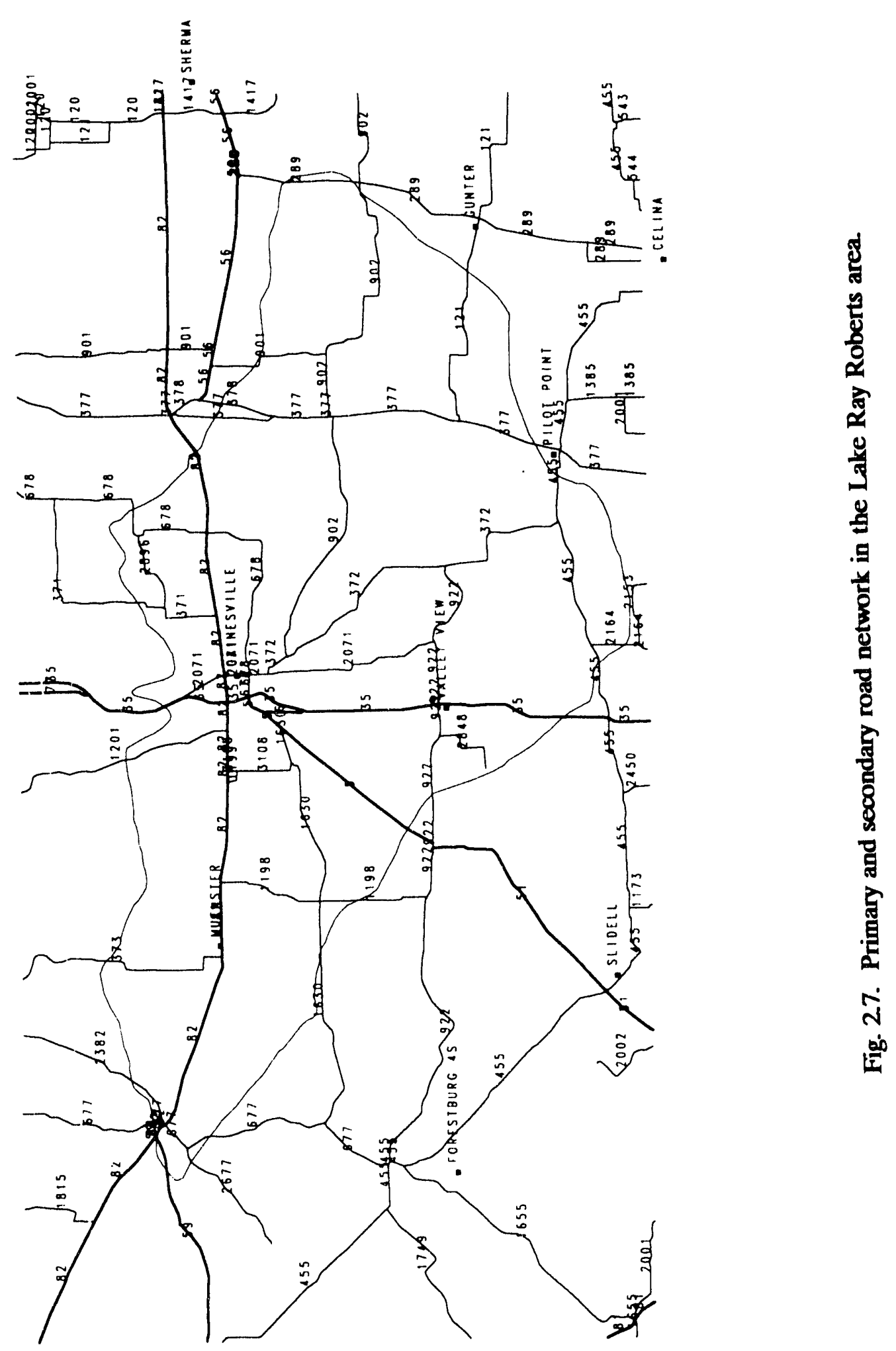




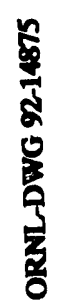
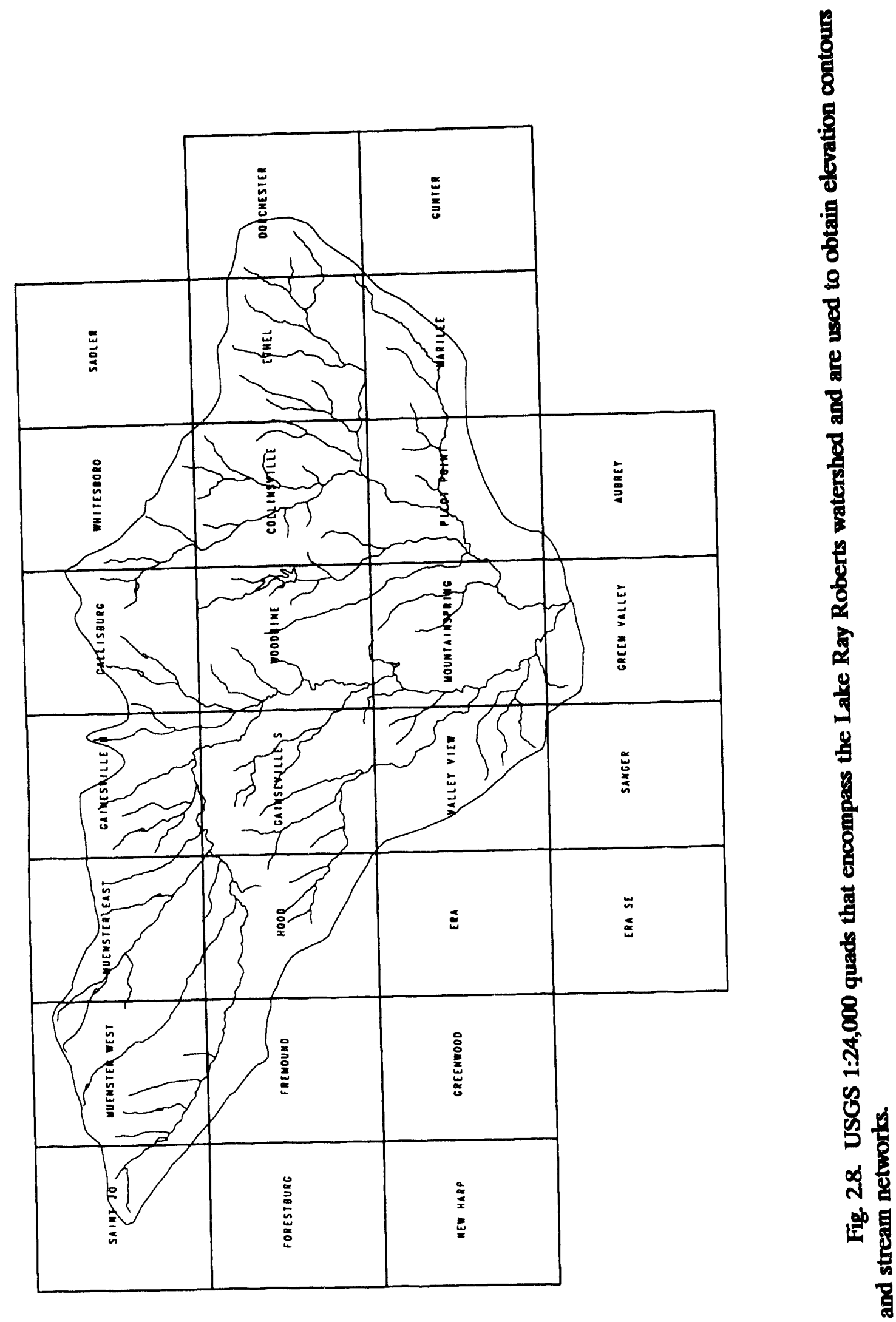
Watershed boundaries were manually delineated onto each quadsheet. Watershed boundaries, streams, and contours were digitized into a single file for each quadrangle using ARC/INFO software. Watershed ares were assigned an identification (ID) value of 1 , streams were assigned an ID value of 100 , and elevation contours were assigned an ID equal to their elevation in feet. To reduce the amount of digitizing, some contour lines were not digitized. These were selected on the basis of the general appearance of the density of the contours and the amount of information added by each contour. For instance, if there was a series of five contours following a parallel course and only a few millimeters apart, every other contour was digitized. Parts of contours were digitized where digitization when appeared to provide additional useful information about the surface of the local landscape. These files were transformed and projected into the Universal Transverse Mercator (UTM) coordinate system and edited. Extreme care was taken to ensure that contours did not cross each other and that a stream did not cross the same contour elevation twice. This was important for generating a DEM.

The streams, watersheds, and elevation ares for each quadrangle were split into separate files. One watershed-wide coverage for each was then created with the use of ARC/INFO. These files were then edited and cleaned. Rectangular polygons encompassing each watershed were generated and used to clip each of the three coverages. The extent of each rectangle was exactly that of the associated IDRISI watershed array. Watersheds are listed with the array sizes and UTM coordinates in Table 2.3.

\subsubsection{Creating digital elevation models}

Each watershed file was converted to ASCII format and exported to use in a program that generates a DEM from contours and stream lines. This requires interpolation between the contour lines. Because the analysis is hydrologically based, it was important that the elevations along the stream network were the local low elevations so that the streams never flowed uphill. These situations often occur when using generic surface DEM generation programs such as ARCTIN (ESRI 1987).

A custom program, Contour-to-Grid, which was used to interpolate a DEM from ARC/INFO contour data, ensures localized lows along the streams and localized highs along the ridge tops. Contour-to-Grid was developed to prepare high-resolution DEMs for hydrologic models. The program lays a grid of a user-specified resolution over the file containing the contour lines and the stream and ridge lines. The program finds the nearest two contours with different values for each point, determines the length of the line from one contour through the sample point to the other contour, and determines how far along the line the point is located. The program takes the proportion of line length from the low contour to the sample point and the total line length and linearly interpolates a value between the two elevations of the contour lines. This value is assigned to the sample point. In the case of stream valleys and ridge tops, the first two contour lines that the program finds are often at the same elevation or the same elevation or the same contour. To allow interpolation, the program finds the closest point between the sample point and the stream or ridge lines, interpolates along these lines for an 
Table 2.3. UTM minimum and maximum coordinates and IDRISI array dimensions for each watershed.

\begin{tabular}{lcccccc}
\hline & \multicolumn{3}{c}{ UTM coordinates } & \multicolumn{3}{c}{$\begin{array}{c}\text { IDRISI } \\
\text { Dimensions }\end{array}$} \\
\cline { 2 - 7 } Watershed & Minimum & Maximum & Minimum & Maximum & Columns & Rows \\
\cline { 2 - 7 } & $\mathbf{X}$ & $\mathbf{X}$ & $\mathbf{Y}$ & $\mathbf{Y}$ & & \\
\hline Entire Area & 632,500 & 713,760 & $3,691,320$ & $3,733,920$ & 4068 & 2136 \\
TR4 & 632,500 & 673,600 & $3,714,620$ & $3,733,920$ & 2055 & 965 \\
TR3 & 664,520 & 681,700 & $3,706,900$ & $3,731,760$ & 859 & 1243 \\
TR2 & 670,400 & 680,920 & $3,700,100$ & $3,712,060$ & 527 & 598 \\
TR1 & 666,320 & 679,740 & $3,693,900$ & $3,704,400$ & 671 & 525 \\
Spring Creek & 654,700 & 675,500 & $3,699,720$ & $3,719,920$ & 1041 & 1011 \\
Timber Creek & 679,920 & 692,520 & $3,713,900$ & $3,732,700$ & 631 & 941 \\
Indian Creek & 679,900 & 690,280 & $3,701,520$ & $3,727,100$ & 519 & 1279 \\
Wolf Creek & 679,260 & 687,080 & $3,701,420$ & $3,719,180$ & 391 & 888 \\
Buck Creek & 690,140 & 712,940 & $3,699,420$ & $3,711,620$ & 1141 & 611 \\
Range Creek & 694,240 & 713,860 & $3,706,400$ & $3,721,800$ & 989 & 770 \\
IDB3 & 687,620 & 699,360 & $3,701,300$ & $3,726,440$ & 587 & 1257 \\
IDB2 & 689,120 & 693,340 & $3,701,540$ & $3,807,240$ & 211 & 286 \\
IDB1 & 684,880 & 691,360 & $3,696,200$ & $3,704,040$ & 324 & 392 \\
\hline
\end{tabular}


elevation, and uses this elevation a the second contour elevation to interpolate a value for the sample point. The methodology is similar to one used in a program developed for the removal of spurious pits in a DEM (Hutchinson 1989).

\subsubsection{Slope and direction of flow}

The DEM's resulting from this procedure was used to generate several additional data layers. Slope angle and direction of flow were determined for each $20 \mathrm{~m}$ cell in the sub-watersheds. These were generated using several programs developed by USGS (Jensen and Domingue 1988) and optimized at Oak Ridge National Laboratory (ORNL). The direction of water flow is calculated by determining the greatestg elevation change between the eight neighbor cells and each central cell. A value is assigned to the central cell indicating the direction from which flow comes.

The file for direction of flow was used to generate a COUNT file for each subwatershed. The COUNT program counts the number of cells that flow into each cell and stores that number in each cell. Each cell value represents the watershed area for that cell. The highest value in each COUNT file is at the watershed outlet and is equal to the number of cells in watershed.

With the use of a visual overlay, it was determined that a cell value of 200 or greater approximated the stream network digitized from the 1:24,000 map sheets. Because these streams represent base flow conditions, this was the minimum stream network the model would use when calibration started. Therefore, the COUNT file was reclassified so tht all values $>200$ were changed to 200 . This allowed the data to be stored in byte format and reduced the memory requirements of the data set.

\subsection{POTENTIAL LOAD ESTIMATION}

\subsubsection{Nutrients}

A compilation of export coefficients (Reckhow et al. 1980) and research from the Southern Plains Agricultural Research Station (Sharpley et al. 1988) was used to obtain estimates for potential loads of total phosphorus and total nitrogen. These are assigned by land use, and each landuse type releases a characteristic amount of a nutrient over a year. Standard methods suggest the selection of three sets of export coefficcients for each land use (high, medium, and low) to allow an estimation of uncertainty in the resultant prediction (Reckhow et al. 1980). For my models, one set of export coefficients was selected using the watershed matching technique described by Reckhow et al. (1980). Export coefficients were selected, from published coefficients, from watersheds with soil, rainfall, slopes, and land management characteristics that most closely matrhed those in the study watershed (Table 2.4). 
Table 24. Export coefficients as used for total phosphorus and total nitrogen potential loads. Coefficients are expressed in unitss commonly found in the literature (kg/ha/year) and in units used to model potential load from individual cells in the spatial data base (gm/cell/year); 1 cell $=400 \mathrm{~m}^{2}$.

\begin{tabular}{lcccc}
\hline & \multicolumn{2}{c}{ Total phosphorus } & \multicolumn{2}{c}{ Total nitrogen } \\
Land use & $\mathrm{kg} / \mathrm{ha} / \mathrm{year}$ & $\mathrm{gm} / \mathrm{cell} / \mathrm{year}$ & $\mathrm{kg} / \mathrm{ha} / \mathrm{year}$ & $\mathrm{gm} / \mathrm{cell} / \mathrm{year}$ \\
\hline Forest & 0.21 & 8.48 & 2.46 & 98.40 \\
Barren & 1.30 & 52.00 & 4.40 & 176.00 \\
Cropland & 2.20 & 88.00 & 9.30 & 372.00 \\
Pasture & 1.46 & 58.4 & 6.13 & 245.00 \\
Rangeland & 0.25 & 10.00 & 1.48 & 59.20 \\
Developed & 0.25 & 17.2 & 1.48 & 59.20 \\
\hline
\end{tabular}

Note: Values are in units reported in the literature and in units matching the data resolution of the data base. Loading values came from the following sources:

Forest - Bedient et al. 1978. Woodlands, Texas.

Barren - Sharpley et al. 1988. Chicasau, Oklahoma.

Cropland - Sharpley et al. 1988. Chicasau, Oklahoma.

Pasture (maintained) - Menzel et al. 1978. Chicasau, Oklahoma.

Rangeland (natural) - Menzel et al. 1978. Chicasau, Oklahoma.

Developed - Betson 1978. Knoxville, Tennessee. 


\subsubsection{Sediment}

Potential total suspended solid load was estimated using the USLE (Wischmeier and Smith 1978). The USLE is defined by the following equation:

where

$$
A=R K L S C P \text {, }
$$

$$
\begin{aligned}
& A=\text { average annual soil loss per unit area } \\
& \quad \text { (tons/ha-year) } \\
& R=\text { rainfall and runoff factor, } \\
& K=\text { soil erodibility factor, } \\
& L=\text { slope-length factor, } \\
& S=\text { steepness factor, } \\
& C=\text { cover and management factor, } \\
& P=\text { support practice factor. }
\end{aligned}
$$

The rainfall $(R)$ factor and conservation practice factor $(P)$ were assigned 275 and 0.2 , respectively, for all watersheds. The $R$ factor was obtained from an SCS Technical Release (U.S. SCS 1975) and has been used in the Ray Roberts watershed in other studies (Del Regno and Atkinson 1988). The $(P)$ factor used is in the low range of typical values used where slopes are between 2 and $7 \%$. Slopes in the Ray Roberts watershed average $<2 \%$; therefore, $P=0.2$ was assigned. The soil erodibility factors were obtained for each soil from the appropriate county soil surveys (USDA 1978, 1979, 1980a, 1980b). 1981):

The slope length $(L)$ was calculated using the following equation (Schwab et al.

where

$$
L=(1 / 22)^{x}
$$

$$
\begin{aligned}
& l=\text { length of flow (meters), } \\
& x=\text { slope factor, } \\
& 0.5 \text { for slopes }>4 \%, \\
& 0.4 \text { for slopes }=4 \%, \\
& 0.3 \text { for slopes }<4 \%
\end{aligned}
$$

The length $(l)$ in Eq. 2.2 was assigned according to the direction of flow. Length was taken as $20 \mathrm{~m}$ if flow was straight across a cell and $28.28 \mathrm{~m}(20 \sqrt{2})$ for cells with diagonal flow. Percent slope was calculated using the DEMs and the SLOPE program from Jensen and Domingues' (1988) series of programs. al. 1981):

The slope steepness factor was calculated using the following equation (Schwab et

$$
S=\left(0.43+0.30 s+0.043 s^{2}\right) / 6.574
$$

where 


$$
s=\text { percent slope. }
$$

The cover and management factor was assigned on the basis of the land use/land cover (Table 2.5).

Table 2.5. Cover and management factor $C$ used in the USLE model.

\begin{tabular}{lc}
\hline Land & Cover and Management factor $C$ \\
\hline Forest & 0.003 \\
Barren & 0.36 \\
Cropland & 0.26 \\
Pasture & 0.013 \\
Rangeland & 0.012 \\
Developed & 0.003 \\
\hline
\end{tabular}

Source: Dunne and Leopold 1978, Tables 15-3 and 15-4.

An IDRISI module was written in Turbo Pascal that calculates the USLE for each cell using the metric form of the USLE (Appendix C). The program reads a single file with slope, slope length, and land-cover codes for each cell. It then calculates the $L S$ and determines the $C$ factors in the USLE model. The USLE module output is a file with potential sediment yield from each cell in metric tons per year.

\subsection{CELL DELIVERY RATIO MODELS}

\subsubsection{Selection of Vegetated Filter Strip Studies}

The only group of vegetated filter-strip (VFS) studies that appears to be easily comparable is the research that used multiple plots, including control plots, with several treatments and repetitions. These studies are well-designed and use consistent measurement techniques over a variety of conditions. From these VFS studies, a compilation of conditions and results will be developed, much like that of Reckhow et al. (1980) for the nutrient export coefficients. Using this compilation and following the theme of Rast and Lee (1983) in developing national export coefficients and Wischmeier and Smith (1978) in developing the USLE, I developed models from the selected studies that describe removal (or trapping) efficiencies based on conditions such as vegetation, soil properties, slope, and flow distance. These removal efficiencies are the inverse of delivery ratios. 
To select comparable filter-strip research efforts, I developed the following criteria. Each study must

- be performed on physically controlled plots;

- have results reported in percent loss of nutrient or sediment (or be able to calculate percent removal myself from the data given);

- have at least three replicates for each treatment;

- have a control (nontreatment) plot;

- have a sufficient description of the study site, including soil types, vegetation, agricultural practices, slopes, distances of flow from originating point to measurement point, rainfall, and nutrient application rates; and

- have some statistical description of the variance about the means of the percent reductions.

The statistical criterion was seldom met and had to be relaxed to obtain enough records to perform the analysis. Lack of quantification of data variability and significance was a major problem with the body of literature reviewed, and future research reports should contain such information. In the future, journal editors and reviewers should be stricter in requiring statistical descriptions and significance tests.

\subsubsection{Data Base of Filter Strip Efficiencies}

Of the hundreds of studies reviewed, only 13 fit the criteria described above. These 13 studies ranged in type from surface runoff across a forest floor to runoff across bare ground, from three replicates representing a single storm event to hundreds of replicates from rainfall events for an entire year, and from natural loadings from untreated plots to loadings from paved beef feedlots. The most common aspects of these studies are the physical design and the elements measured. From these 13 studies, 73 records were created describing results from plots with varying treatments (Appendix B). Forty-three of these records reported percent reductions of sediment or nutrients in concentration units, whereas the remaining 30 reported results in percent reduction in mass units. Further analyses were performed on concentration and mass data sets separately. Therefore, two equations for each dependent variable were developed to describe reduction in concentration and in mass. Additionally, the number of repetitions within a study was used to attempt to establish a confidence level in the models in lieu of statistical variability reporting.

For each treatment record several parameters were recorded directly, and several were estimated from study plot descriptions. For instance, slope, distance of flow, vegetation type, soil type, and texture were obtained direclly from each study description. Soil type and texture were used to obtain some physical description of the soils if this was 
not provided in the study description. These included permeability, mean particle diameter size, and the SCS hydrologic soil group class.

Permeability [inches per hour (in./h): the English units were maintained throughout the analysis for ease of comparison to county soil survey data] was estimated using the textural description and Table 3.1 in Novotnoy and Chesters (1981). Mean particle diameter (MPD) (in millimeters) was estimated from Fig. 3.6 in Novotnoy and Chesters (1981). Hydrologic Soil Group classifications were obtained from Table 7.1 in the National Engineering Handbook, Sect. 4, "Hydrology" (U.S. SCS 1972). Vegetation type and agricultural practice, if applicable, were used to estimate Manning's roughness coefficient (n) from Table 5 provided by Engman (1986). Engman describes a set of coefficients developed for overland flow modeling as opposed to channel flow for which Manning's roughness coefficient was originally developed. Each of these parameters has been identified as being important in controlling water, nutrient, and sediment movement in overland flow (Brady 1974, Dunne and Leopold 1978, Novotnoy and Chesters 1981, Schwab et al. 1981, and Phillips 1989a, b). In fact, some of these parameters are used specifically by Phillips [Eqs. (1 and 1.2)] and by many other models such as ANSWERS, AGNPS, and CREAMS.

Appendix B contains a complete listing of the parameters and reported results, expressed as percent reduction in sediment or nutrient mass or concentrations, from the 13 studies analyzed. This is the complete data set used in the following analysis. This table could be used to determine trapping efficiencies or delivery ratios by matching study site conditions to reported conditions. This approach is similar to that described for use of the export coefficient tables provided by Reckhow et al. (1980)

\subsubsection{Statistical Analysis}

Five dependent variables were modeled for loss of mass and loss of concentration resulting in ten regression equations: total suspended solids (TSS), total phosphorus (TP), total nitrogen (TN), nitrate-nitrogen $\left(\mathrm{NO}_{3}-\mathrm{N}\right)$ and ammonia-nitrogen $\left(\mathrm{NH}_{4}-\mathrm{N}\right)$. Basic explanatory variables included distance of overland flow, slope, low soil permeability, mean particle diameter of soil, and Manning's roughness coefficient. Hydrologic soil group was dropped from the analysis because it is a class variable and no dependent variable in the data base included all classes.

Additional explanatory variables were created by transformations of the basic variables. First, slope was transformed from percent to slope angle (theta) using a simple arctangent transformation, so all models were using the same variable (e.g., Eqs. 1.1 and 1.2). In addition to the five explanatory variables already mentioned, the squares of these variables were also calculated to allow second-order polynomial functions to be modeled. Finally, three interaction terms (distance with permeability, theta, and Manning's roughness coefficient) were developed by multiplying the untransformed values for each record. The resulting data base used for model development, therefore, had 13 explanatory variables. 


\subsubsection{Lincar regression equations}

A forward variable selection procedure ( $R$-square) was used in the regression analysis for each dependent variable, allowing each explanatory variable to enter the regression equation (SAS Institute, Inc. 1985). This procedure produces multiple models by allowing an incrementally increasing number of explanatory variables into the regression equation and switching which terms appear. This allows a rapid comparison between variables and models but also requires that criteria be defined to select appropriate models for further use.

Initially models were selected with an $R^{2}$ of at least $0.8($ ) (or as close as could be obtained) and $P<0.05$. A set of criteria was used to ensure statistical significance and validity and to reduce problems with eollinearity or interdependency among the explanatory variables. I used three generally recommended statistical criteria, as outlined by Draper and Smith (1981). First, the sum-of-square error (SSE) for the reduced model could not differ signilicantly from the SSE for the full model. Second, 95\% of the variance explained by the full model had to be explained by the reduced model. Third. the Mallows $C p$ statistic had to be reasonably aceeptable, as described by Draper and Smith (1981). Collinearity hetween variables was evaluated using the maximum condition index described by Belsley et al. (1980). Models with several variables collinearly related were eliminated from further evaluation.

Additional criteria for model selection were selected relative to the intended use of the model and to ensure scientific validity. Because the intended use was $t o$ drive a spatially explicit nutrient-and sediment-movement model, distance, in some form, had to be in each equation. Also, the sign of the coefficients had to be logical. For example, the dependent variable should increase as distance of llow increases, meaning that as distance increases the amount of an element retained in the filter strip increases. Also, if the quadratic form of a variable was identilied as an important explanatory variable, then a model was selected that had both the linear and quadratic forms of the variable. The second order approximation had to include both forms of the variable ( $X$ and $\left.X^{2}\right)$.

Several limitations to model development resulted from the nature of the data base. Initially I planned to give each record equal weight or equal influence in the development of a model, despite the fact that sample size (or repetitions) per record varied. Typically weighting is implemented using information about the variation of the dependent variables. This requires knowledge of variations around the reported means, which was not always available. However, an attempt was made to account for the variation using the sample size for each record. Each mean was weighted by the number of repetitions used to calculate the mean. The assumption behind this procedure is that the variance of the mean value is inversely proportional to the sample size; a mean based on 50 values, for instance, is a more accurate estimate of the true mean than a number based on 3 values. Regressions were performed with and without the weighting with little or no difference in the $R^{2}$ values or the significance level of the estimated models. Therefore, weighting was dropped from the remainder of the analysis.

On the basis of the previously discussed criteria, several models were chosen for each dependent variable, and a regression analysis (PROC REG) (SAS Institute Inc. 
1985) was performed to obtain estimates of parameter coefficients, influence diagnostics, collinearity indices, and Types I and II partial SSEs to obtain a measure of individual contribution of each variable to variability in model estimates. Type I and II errors were further analyzed by dividing individual Type II SSEs by the SSE for the full model. This procedure produces an $\mathbf{R}^{2}$ value representing the proportion of variability explained by each variable, given that all sther variables are in the model. Finally, plots of residuals against each explanatory variable were produced to detec the models.

Preliminary results from the influence diagnostics dictated that several data points were having a significant influence on the estimated model; therefore, they were dropped from the analysis. These were the highly negative retention values which had an undue influence on the overall models as identified by RSTUDENT and DFFITS values produced during the regression analysis (SAS Institute, Inc. 1985). Specifically, records whose values were $-67,48$, and 2 for total nitrogen were dropped. Records with values of $-999,-81,-341 \mathrm{v}$ эre dropped for the nitrate-nitrogen analysis. Records with values of $400,-600,-35$, and -21 were dropped from the ammonia-nitrogen analysis. These records were all in the mass data set.

The high negative values reported in the e papers indicate that the response variable actually increased as water flowed across the VFS under study. This is probably caused by the complex transformations of the nitrogen species. The reported values are not necessarily incorrect, but because they are so different from the nther values being used, they have an extreme influence on the estimated model and, therefore, affect the ability of the model to predict observed values within the range of the remainder of the data. Tuo records were dropped from the total suspended solids concentration analysis (record values 37 and 92), also because of excessive influence on model performance. Although these values are within the range of the other data points for this data set, multiple records with similar independent variable values were so different that these points were influencing the predictive ability of the models more than was acceptable.

Multiple models (equations) for each dependent variable resulted from the analysis. In some instances, the criteria discussed earlier made the ultimate selection of an appropriate model easier by eliminating all choices but one. In other cases, several models fit all of the criteria. When several models with different explanatory variables were equally effective in explaining variations in dependent variables, the model was chosen with the same parameters as the models from the other dependent variable models. The overall intent was to limit the effort required to build a data base that woulc run all the models and enhance model comparison.

If all the dependent variable models use the same independent variables, both data base creation and actual encoding of the models into a distributed ype of analysis is much simpler. Again, the goal of this study was to use these models to drive a distributed parameter GIS-based NPS loading model. The raw data are provided in Appendix B so that one can identify additional models that may be more appropriate to a different application. More important, data cou'd be added to the data base and the analysis rerun in the hope that the power of the models could be increased. 


\subsubsection{Nonlinear regression equations}

The models developed from the procedure outlined in the previous section were the best for describing the data used to develop the models; however, when applied to the Ray Roberts watershed data, the equations did not work well. The three models were tested using the Timber Creek data set. The models were expected to result in values between 0 and $100 \%$ delivery but resulted in values ranging from -50 to more than $500 \%$. Although this was disconcerting, a comparison of the model data set and the test data set effers an explanation. Individually, values for each explanatory variable in the test data set were within range of the model data set. However, combinations of explanatory variables for each cell in the test data set were sometimes outside the range of the space defined by the model data set, as shown in Fig. 2.9. If ranges in the model data set are examined one variable at a time, the data set would appear to occupy the space defined by the shaded rectangle (Fig. 2.9a). However, when actually plotted, the data used in the models occupy only the space defined by the shaded area (Fig. 2.9b). The use of values in the test data set that fall outside this space produced erroneous results.

To solve this problem, additional statistical modeling was performed. The Marquardt method of the nonlinear (NL.IN) procedure (SAS Institute, Inc. 1985) was used to generate nonlinear forms of equations for trapping efficiencies of masses of total phosphorus, total nitrogen, and total suspended solids. These were the only pollutants used in the NLIN analysis because I could estimate only potential loads in the study watersheds for these three pollutants. Export coeflicients for ammonia-nitrogen and nitrate-nitrogen are not widely available in the litcrature. 
(a)

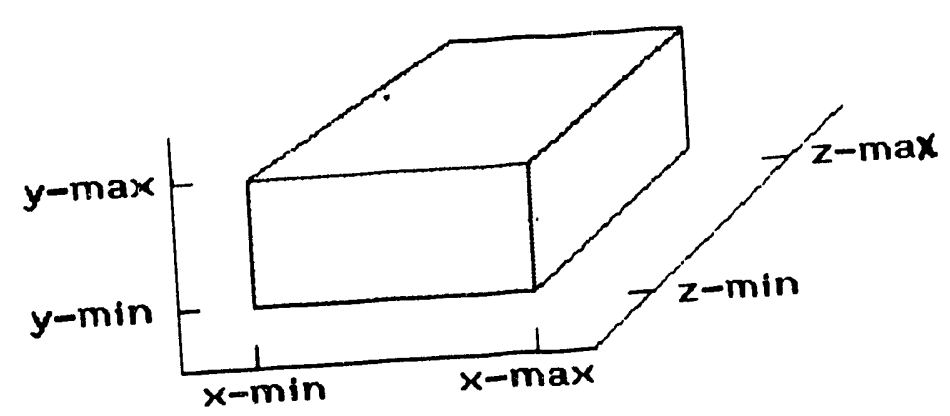

(b)

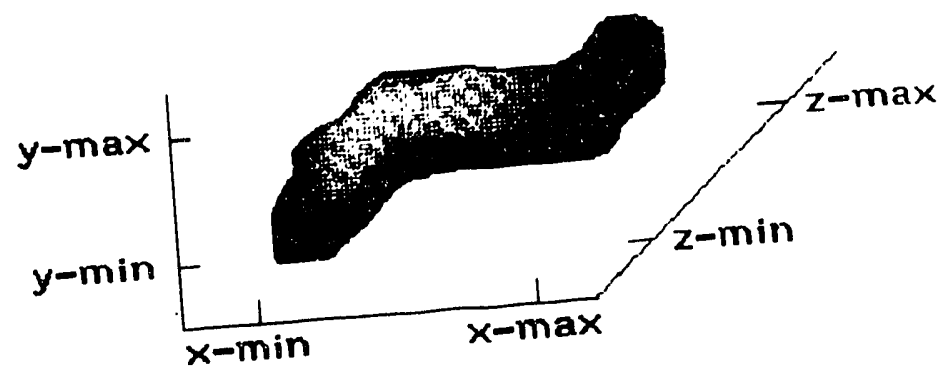

Fig. 2.9. Graphical representation of theoretical data space and actual data space used to develop multiple regression models. The shaded box $(a)$ represents the total space occupied all the space defined by the maximums area occupied by ata set with the same axis. The shaded space $(b)$ represents values do not maximum and minimums for each $(a)$. 
Several steps were required before the NLIN procedure was used. First, the dependent variables were transformed into proportions by dividing the values by 100 . The $R$-Square procedure was then used with these transformed values to obtain parameter estimates of each explanatory variable. The new models were selected on the basis of the transformed dependent variables and used to create models in the NLIN procedure. NLIN uses the coefficient estimates as a starting point and optimizes the models by changing the coefficient values. The resulting models were in this form:

$$
P / 100=1 /\left(1+\mathrm{e}^{b 0+b 1 X 1+\ldots b n X n}\right),
$$

where

$$
\begin{aligned}
& P=\text { percent delivery for the pollutant } \\
& b=\text { coefficient for explanatory } \\
& \quad \text { variable } n \\
& X=\text { value of explanatory variable } n .
\end{aligned}
$$

This equation forces values to be between 0 and 100. A sensitivity analysis was performed on the three nonlinear models by incrementally changing values for each input variable while holding the others constant. The range of values used in the sensitivity analysis was the same as the range of values for each variable found in the entire Ray Roberts watershed. Finally, the models were tested with the Timber Creek data set.

\subsection{MODELING PROCEDURE}

The overall model that calculates total loads of total phosphorus, total nitrogen, and total suspended solids is actually a series of models run in succession (Fig. 2.10). Each component is described in detail below.

\subsubsection{Calculate Cell Delivery Ratios}

An IDRISI module, written in Turbo Pascal, calculates cell delivery values on the basis of the nonlinear delivery ratio models developed using the process described previously (Appendix D). The model calculates a cell delivery value for each cell. To reduce the île-reading operations, all input data for each watershed were combined into one file. The delivery models need distance of flow, percent slope, soil mean particle diameter, soil permeability, and Manning's roughness coefficient. These all come from four GIS data layers: soil type, slope, distance, and land use. Values for these parameters can be represented with a six-digit code with a positive or negative sign. The first two digits represent the soil identification code, which is used to index permeability and MPD in the program itself using a CASE statement. There are 31 possible instances of soil MPD and permeability combinations given the soil types in the Ray Roberts watershed. The next digit is the land-use code, which is used to index a Manning's roughness coefficient (Table 2.6). 
5
$\vdots$
$\vdots$
0
0
5
$\vdots$
0

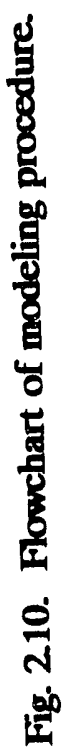
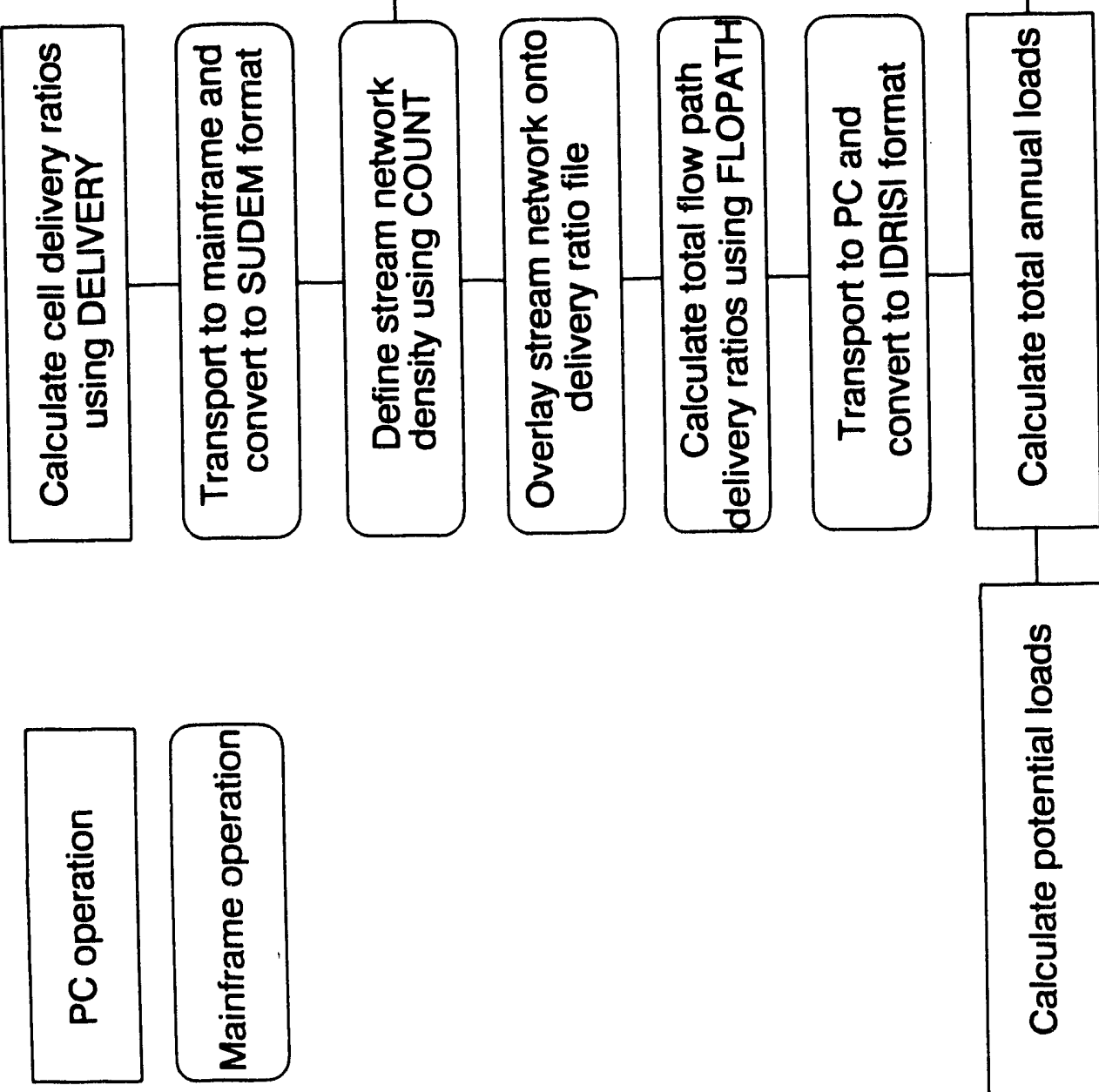
Table 2.6 Manning's roughness coeflicient (n) assigned to land uses in the delivery ratio program (Engman 1986)

Land use Manning's roughness coefficient $(n)$

\begin{tabular}{ll}
\hline Water & 0.046 \\
Forest & 0.40 \\
Barren & 0.05 \\
Cropland & 0.18 \\
Pasture & 0.10 \\
Rangeland & 0.24 \\
Developed & 0.04 \\
\hline
\end{tabular}

The last three digits are the percent slope, which is converted into the sine of the slope angle in the program. Finally, the sign indicates the distance of flow across a cell: $20 \mathrm{~m}$ for negative and $28.29 \mathrm{~m}$ for positive. The generation of this file was relatively simple in IDRISI, and it makes programming easier by reducing the number of large open files and, therefore, reducing memory requirements. This approach also reduces the number of read file operations that require considerable central processing unit (CPU) time.

\subsubsection{Transport to Mainframe}

The DELIVERY model for each pollutant and watershed was run on a personal computer (PC). The output files were loaded onto a VAX 3500 and converted to a standard unformatted DEM (SUDEM) format required by the DEM processing modules.

\subsubsection{Define Stream Network}

The cell delivery files were generated without the stream network included. The stream network was defined by assigning a value of 100 to each cell in the stream network and a value of 0 for all other cells. This assumes $100 \%$ delivery once a pollutant reaches the stream network. The model was calibrated by increasing the number of cells considered to be in the stream network using the COUNT method described earlier.

The loading models were calibrated separately in the three physiographic regic ns, using one watershed from each region. The single COUNT threshold with the best rusults for all three pollutant models in the calibration watersheds was selected instead of calibrating each pollutant model separately. Better results for each model may have been possible if each pollutant model had been calibrated separately; however, that approach would suggest that hydrology was different for each model, which is not possible. 


\subsubsection{Overlay Stream Network onto Delivery File}

The stream network file was overlaid onto the cell delivery file by adding the values from matching cells in each file. This resulted in a file with values ranging from 0 to 200. This file was edited to set all values over 100 equal to 100 .

\subsubsection{Calculate Total Flow Path Delivery Ratios}

A Fortran program, FLOPATH, was written to convert the cell delivery ratios to total flow path delivery ratios within a watershed. The algorithm is based on a program, WATERSHED, written by Jensen and Domingue (1988) for delineating watersheds from DEMs. WATERSHED works by using the direction-of-flow file and a seed cell, the watershed outlet. The algorithm starts by searching the eight adjacent cells of the seed cell, determines which cells are directed toward the seed cell, and assigns a common index number to all the cells that flow to the seed cell. The program then steps to the first neighbor cell that did flow to the seed and treats it as the seed. The program walks up successive arms of each contributing neighbor until all contiguous cells have been found. The output file is an image with values associated with the watershed it belongs in and zero's in cells outside a watershed.

This algorithm was expanded to use the direction-of-flow file and a file with the cell delivery ratios and to generate a total flow path delivery ratio for each cell within a watershed. FLOPATH starts at the watershed outlet and (1) determines which neighbor cells contribute flow to it, (2) interrogates the cell delivery ratio file for the values of the seed cell and the neighbor cells that do flow into it, and (3) multiplies the delivery value for the seed cell by the delivery value of the neighbor cell and stores the result in a new file at the coordinates of the neighbor cell.

Like WATERSHED, FLOPATH builds networks of contributing areas and steps up each successively. To do this, FLOPATH keeps track of the cells that flow into each cell along the hydrologic flow path. This requires substantial memory to hold values for the two arrays and the temporary arrays which store the cell coordinates for cells from which multiple flow paths originate. The output from FLOPATH is a file that has accumulated flow path delivery ratios for the particular pollutant that is being modeled. FLOPATH code is provided in Appendix E.

\subsubsection{Transport to Personal Computer}

Output from FLOPATH was converted to ASCII format and loaded back to a PC. This is the reverse of step 2 . The remainder of the analysis was performed on a PC. 


\subsubsection{Calculate Total Annual Load}

To calculate total loading, the total flow path delivery file was multiplied cell by cell with the potential loading file. This file was interrogated for total mass delivered from each cell to get the total mass that passes the watershed outlet point on an annual basis.

\subsubsection{Compare Estimated Load to Observed Load}

The estimated load value was compared with the total mass actually measured.

\subsubsection{Calibration}

For the calibration watersheds, the process went back to step 3 until a reasonable match between estimated and observed values was reached. One watershed from each of the three physiographic regions was used to calibrate the model for each region. The remaining watersheds were modeled with the use of the COUNT threshold determined by this calibration procedure.

The difference between observed and modeled mass was compared to with zero with a matched-pair Student's t-test. All the watersheds were used for this test.

\section{RESULTS AND DISCUSSION}

\subsection{OBSERVED LOAD CALCULATIONS}

Observed annual loads for total phosphorus, total nitrogen, and total suspended solids for each watershed are presented in Appendix F. The model estimates of annual loads were compared with these observed values. An inspection of the observed loads for each sampling period demonstrates a problem with this type of annual load calculation. Each instantaneous measurement represents flow and concentration conditions throughout the period (13.5-18 days) that brackets the sampling date. Thus, I assume that the samples taken on the dates shown in the tables in Appendix F represent the average flow and concentration conditions for that period.

Although while there was no way other than continuous sampling to test whether this assumption has been violated, comparisons with other loading values in the same watersheds during different years offer insight about the calculated loads. Pillard (1988) reported annual loads, calculated from daily loads, for total nitrogen, total phosphorus, and total suspended solids for the TR1 and IDB1 watersheds for each year from 1976 to 1983, representing a variety of rainfall conditions including very dry and very wet years. The 1985-1986 water year, which was used to develop the model, was an average rainfall year. Annual loads of total phosphorus for the TR1 watershed ranged from $10.8 \times 10^{3}$ $\mathrm{kg} /$ year in 1978 to $361.1 \times 10^{3} \mathrm{~kg} /$ year for 1981 , with an average load for the 1976-1983 
period of $98.6 \times 10^{3} \mathrm{~kg} /$ year. The observed total phosphorus load from TR1 (Appendix F, Table 8) was calculated to be $37.8 \times 10^{3} \mathrm{~kg} /$ year, well within the range of loads for lowrainfall and high-rainfall years. Observed loads for all three pollutants for both TR1 and IDB1 watersheds fall within the ranges of loads reported by Pillard (1988). Therefore, the observed annual loads (Appendix F) are adequate for model calibration and evaluation.

\subsection{DELIVERY RATIOS}

\subsubsection{Lincar Models}

Linear models of buffer-strip-trapping efficiencies are presented in Tables 3.1 for mass and 3.2 for concentration. The amount of variation in the dependent variable explained by the models for mass and concentration reductions ranged from $75 \%$ for total suspended solids mass to $94 \%$ for nitrate-nitrogen concentration.

\subsubsection{Mass-regression models}

By design, distance was included in each equation even though it did not explain much of the variation in the dependent variable in some cases. For ammonia-nitrogen, distance was the most important parameter in explaining variation in percent reduction (15\%). However, in the nitrate and total nitrogen equations, distance was not very important at all $\left(R^{2}\right.$ proportion $=0.06$ and 0.03 , respectively). Additionally, distance was an important factor in explaining trapping efficiencies of total suspended solids $(17 \%)$ and total phosphorus $(21 \%)$. In only one case (total suspended solids) did distance enter the regression equation as a second-order polynomial. This suggests that, in general, distance is linearly related to buffer efficiency. The positive sign also indicates as expected, that as distance increases so does trapping efficiency. 
Table 3.1. Linear models of vegetated filter-strip-trapping efficiency for mass of ammonia nitrogen (A), nitrate nitrogen (B), total nitrogen (C), total phosphorus (D), and total suspended solids (E)

\begin{tabular}{|c|c|c|c|c|c|}
\hline Parameter & $\begin{array}{l}\text { Estimated } \\
\text { coefficient }\end{array}$ & $\begin{array}{c}\text { Standard } \\
\text { error }\end{array}$ & $\begin{array}{c}\text { Prob> } \\
|\mathrm{T}|\end{array}$ & $\begin{array}{c}\text { Standardized } \\
\text { estimate }\end{array}$ & $\begin{array}{c}R^{2}- \\
\text { Proportion }\end{array}$ \\
\hline \multicolumn{6}{|c|}{ A. Ammonia nitrogen $-R^{2}=0.89(n=16)$} \\
\hline Intercept & 548.73 & 260.23 & 0.07 & & 0.06 \\
\hline Distance & 7.41 & 2.27 & 0.01 & 2.67 & 0.15 \\
\hline Theta & $-20,692.78$ & $9,412.35$ & 0.06 & -33.64 & 0.07 \\
\hline$(\text { Theta })^{2}$ & $74,359.24$ & $35,315.39$ & 0.07 & 22.18 & 0.06 \\
\hline Roughness & 891.99 & 327.72 & 0.03 & 1.85 & 0.10 \\
\hline (Roughness) $^{2}$ & $-3,394.39$ & $1,121.29$ & 0.02 & -1.92 & 0.13 \\
\hline Permeability & $1,480.98$ & 618.45 & 0.04 & 53.13 & 0.08 \\
\hline$\left(^{\text {Permeability })^{2}}\right.$ & -595.81 & 224.56 & 0.04 & -60.42 & 0.08 \\
\hline \multicolumn{6}{|c|}{ B. Nitrate nitrogen $-R^{2}=0.81(n=16)$. } \\
\hline Intercept & 681.16 & 360.91 & 0.10 & & 0.09 \\
\hline Distance & 28.99 & 18.33 & 0.15 & 6.99 & 0.06 \\
\hline Theta & $-36,357.97$ & $16,709.41$ & 0.06 & -46.67 & 0.11 \\
\hline$(\text { Theta })^{2}$ & $139,159.39$ & $65,163.43$ & 0.07 & 34.93 & 0.11 \\
\hline Roughness & 925.53 & 340.85 & 0.03 & 0.58 & 0.18 \\
\hline Distance*Theta & -163.44 & 135.48 & 0.26 & -1.71 & 0.04 \\
\hline Permeability & $2,837.84$ & $1,341.92$ & 0.07 & 55.10 & 0.11 \\
\hline${\text { (Permeability })^{2}}^{2}$ & $-1,150.81$ & 539.69 & 0.07 & -61.06 & 0.11 \\
\hline
\end{tabular}


Table 3.1. Continued.

\begin{tabular}{crrrrr}
\hline Parameter & $\begin{array}{c}\text { Estimated } \\
\text { coefficient }\end{array}$ & $\begin{array}{c}\text { Standard } \\
\text { error }\end{array}$ & $\begin{array}{c}\text { Prob }> \\
|\mathrm{T}|\end{array}$ & $\begin{array}{c}\text { Standardized } \\
\text { estimate }\end{array}$ & $\begin{array}{c}\boldsymbol{R}^{2} \text { - } \\
\text { Proportion }\end{array}$ \\
\hline \multicolumn{7}{c}{ C. Total nitrogen $-\boldsymbol{R}^{2}=\mathbf{0 . 8 8}(\boldsymbol{n}=23)}$. \\
Intercept & $\mathbf{3 1 6 . 5 8}$ & 57.33 & $<0.01$ & \\
Distance & 4.59 & 2.67 & 0.07 & 2.07 & 0.28 \\
Theta & $-1,762.38$ & 379.82 & $<0.01$ & -9.77 & 0.20 \\
(Theta) $^{2}$ & $-5,847.83$ & 379.82 & $<0.01$ & 12.90 & 0.24 \\
Roughness & 886.05 & 238.73 & $<0.01$ & 5.84 & 0.13 \\
(Roughness) $^{2}$ & $-3,208.40$ & 810.57 & $<0.01$ & -9.31 & 0.14 \\
Permeability & -163.73 & 50.84 & $<0.01$ & -12.23 & 0.10 \\
(Permeability) $^{2}$ & 27.20 & 9.36 & 0.01 & 10.71 & 0.08 \\
MPD & -818.29 & 256.23 & $<0.01$ & -3.32 & 0.09 \\
Distance*Theta & -12.62 & 6.94 & 0.09 & -1.37 & 0.03
\end{tabular}

D. Total phosphorus $-R^{2}=0.82(n=29)$.

$\begin{array}{crrrrr}\text { Intercept } & 337.63 & 78.73 & <0.01 & & 0.18 \\ \text { Distance } & 9.26 & 2.01 & <0.01 & 2.95 & 0.21 \\ \text { Theta } & -1,463.56 & 537.73 & 0.01 & -5.18 & 0.07 \\ \text { (Theta) }^{2} & 5,374.80 & 1,743.80 & <0.01 & 7.52 & 0.09 \\ \text { Roughness } & 800.84 & 393.46 & 0.06 & 3.37 & 0.04 \\ \text { (Roughness) }^{2} & -2,911.49 & 1,328.16 & 0.04 & -5.36 & 0.05 \\ \text { Permeability } & -242.08 & 54.44 & <0.01 & -14.27 & 0.19 \\ \text { (Permeability) }^{2} & 42.54 & 9.85 & <0.01 & 13.89 & 0.18 \\ \text { MPD } & -1,150.09 & 291.82 & 0.06 & -2.99 & 0.15 \\ \text { Distance*Theta } & -26.03 & 6.32 & <0.01 & -1.81 & \end{array}$


Table 3.1. Continued

\begin{tabular}{|c|c|c|c|c|c|}
\hline Parameter & $\begin{array}{c}\text { Estimated } \\
\text { coefficient }\end{array}$ & $\begin{array}{c}\text { Standard } \\
\text { error }\end{array}$ & $\begin{array}{c}\text { Prob }> \\
|\mathrm{T}|\end{array}$ & $\begin{array}{c}\text { Standardized } \\
\text { estimate }\end{array}$ & $\begin{array}{c}R^{2}- \\
\text { Proportion } \\
\end{array}$ \\
\hline \multicolumn{6}{|c|}{ E. Total suspended solids $-R^{2}=0.75(n=22)$. } \\
\hline Intercept & 118.82 & 22.84 & $<0.01$ & & 0.43 \\
\hline Distance & 5.81 & 1.80 & $<0.01$ & 3.41 & 0.17 \\
\hline$(\text { Distance })^{2}$ & -0.19 & 0.06 & $<0.01$ & -3.65 & 0.19 \\
\hline Theta & -371.49 & 125.63 & $<0.01$ & -1.16 & 0.14 \\
\hline MPD & -135.19 & 52.29 & 0.02 & -0.71 & 0.11 \\
\hline Permeability & -9.27 & 2.18 & $<0.01$ & -1.13 & 0.29 \\
\hline
\end{tabular}


Table 3.2. Linear models of vegetated filter-strip-trapping efficiency for concentration of ammonia nitrogen (A), nitrate nitrogen (B), total nitrogen (C), total phosphorus (D), and total supended solids (E).

\begin{tabular}{cccccc}
\hline Parameter & $\begin{array}{c}\text { Estimated } \\
\text { coefficient }\end{array}$ & $\begin{array}{c}\text { Standard } \\
\text { error }\end{array}$ & $\begin{array}{c}\text { Prob }> \\
|T|\end{array}$ & $\begin{array}{c}\text { Standardized } \\
\text { estimate }\end{array}$ & $\begin{array}{c}R^{2}- \\
\text { Proportion }\end{array}$ \\
\hline
\end{tabular}

A. Ammonia nitrogen $-R^{2}=0.90(n=30)$.

$\begin{array}{crrrrr}\text { Intercept } & 169.33 & 26.12 & <0.01 & & 0.21 \\ \text { Distance } & 1.18 & 0.27 & <0.01 & 1.26 & 0.10 \\ \text { (Distance) }^{2} & -0.004 & 0.003 & 0.15 & -0.41 & 0.01 \\ \text { Theta } & 940.68 & 208.45 & <0.01 & 1.84 & 0.10 \\ \text { (Theta) }^{2} & -5,023.87 & 1,331.93 & <0.01 & -1.55 & 0.07 \\ \text { Roughness } & -2,536.56 & 633.61 & <0.01 & -3.97 & 0.08 \\ \text { (Roughness) }^{2} & 14,666.95 & 3,598.92 & <0.01 & 4.15 & 0.08 \\ \text { Permability } & -51.83 & 11.11 & <0.01 & -5.02 & 0.11 \\ \text { (Permeability) }^{2} & 10.66 & 2.22 & <0.01 & 5.94 & 0.11 \\ \text { MPD } & -488.29 & 125.92 & <0.01 & -1.06 & 0.07\end{array}$

B. Nitrate nitrogen $-R^{2}=0.94(n=16)$.

\begin{tabular}{|c|c|c|c|c|}
\hline Intercept & 498.81 & 193.69 & 0.02 & \\
\hline Distance & 8.36 & 1.04 & $<0.01$ & 3.57 \\
\hline$(\text { Distance })^{2}$ & -0.16 & 0.02 & $<0.01$ & -2.99 \\
\hline Theta & $-5,988.14$ & $2,236.99$ & 0.02 & -8.52 \\
\hline$(\text { Theta })^{2}$ & $22,819.55$ & $8,783.03$ & 0.03 & 6.35 \\
\hline MPD & $-1,885.49$ & 633.64 & 0.02 & -2.69 \\
\hline
\end{tabular}


Table 3.2. Continued.

\begin{tabular}{|c|c|c|c|c|c|}
\hline Parameter & $\begin{array}{l}\text { Estimated } \\
\text { coefficient }\end{array}$ & $\begin{array}{c}\text { Standard } \\
\text { error }\end{array}$ & $\begin{array}{c}\text { Prob > } \\
|\mathrm{T}|\end{array}$ & $\begin{array}{l}\text { Standardized } \\
\text { estimate }\end{array}$ & $\begin{array}{c}R^{2}- \\
\text { Proportion }\end{array}$ \\
\hline \multicolumn{6}{|c|}{ C. Total nitrogen $-R^{2}=0.78 n=37$. } \\
\hline Intercept & 96.73 & 25.23 & $<0.01$ & & 0.11 \\
\hline Distance & 0.77 & 0.09 & $<0.01$ & 0.94 & 0.53 \\
\hline Theta & $1,204 .(19$ & 197.94 & $<0.01$ & 2.66 & 0.28 \\
\hline$(\text { Theta })^{2}$ & $-5,528.37$ & $1,242.49$ & $<0.01$ & -1.84 & 0.15 \\
\hline Roughness & $-1,890.77$ & 728.42 & 0.02 & -.3 .19 & 0.05 \\
\hline (Roughness) $^{2}$ & $10,854.83$ & $4,137.10$ & 0.01 & 3.32 & 0.05 \\
\hline Permeability & -35.67 & 7.36 & $<0.01$ & -3.77 & 0.18 \\
\hline$(\text { Permeability })^{2}$ & 5.51 & 1.21 & $<0.01$ & 3.37 & 0.16 \\
\hline \multicolumn{6}{|c|}{ D. Total phosphorus $-R^{2}=0.81(n=27)$. } \\
\hline Intcrcept & -135.11 & 33.73 & $<0.01$ & & 0.17 \\
\hline Distance & 1.34 & 0.38 & $<(0.01$ & 1.36 & 0.13 \\
\hline Theta & $2,612.88$ & 377.83 & $<0.01$ & 5.34 & 0.50 \\
\hline$(\text { Theta })^{2}$ & $-10,419.39$ & $1,686.38$ & $<0.01$ & -3.69 & 0.40 \\
\hline Roughness & -450.73 & 129.65 & $<0.01$ & -0.85 & 0.13 \\
\hline MPD & 874.96 & 153.07 & $<0.01$ & 1.84 & 0.34 \\
\hline Permeability & -4.52 & 2.76 & 0.12 & -0.45 & 0.03 \\
\hline Distance*Rough. & 13.29 & 4.83 & 0.01 & -0.96 & 0.08 \\
\hline Distance*Perm. & -0.34 & 0.09 & $<0.01$ & -1.14 & 0.15 \\
\hline
\end{tabular}


Table 3.2. Continued

\begin{tabular}{cccccc}
\hline Parameter & $\begin{array}{c}\text { Estimated } \\
\text { coefficient }\end{array}$ & $\begin{array}{c}\text { Standard } \\
\text { error }\end{array}$ & $\begin{array}{c}\text { Prob }> \\
|\mathrm{T}|\end{array}$ & $\begin{array}{c}\text { Standardized } \\
\text { estimate }\end{array}$ & $\begin{array}{c}\boldsymbol{R}^{2} \text { - } \\
\text { Proportion }\end{array}$ \\
\hline \multicolumn{7}{c}{ E Total suspended solids } & $-R^{2}=\mathbf{0 . 9 0}(\mathbf{n}=30)$. \\
Intercept & 67.85 & 14.64 & $<0.01$ & 0.09 \\
Distance & 0.76 & 0.09 & $<0.01$ & 0.79 & 0.28 \\
Theta & $1,596.79$ & 148.28 & $<0.01$ & 2.83 & 0.49 \\
(Theta) ${ }^{2}$ & $-7,596.08$ & 895.26 & $<0.01$ & -0.65 & 0.31 \\
Permeability & -25.99 & 4.72 & $<0.01$ & -0.65 & 0.13 \\
MPD & -614.91 & 224.49 & 0.01 & 0.24 & 0.03 \\
\hline
\end{tabular}


respectively). Additionally, distance was an important factor in explaining trapping efficiencies of total suspended soli

ds $(17 \%)$ and total phosphorus $(21 \%)$. In only one case (total suspended solids) did distance enter the regression equation as a second-order polynomial. This suggests that, in general, distance is linearly related to buffer efficiency. The positive sign also indicates as expected, that as distance increases so does trapping efficiency.

Theta entered all equations, indicating that slope is important in every case. Slope was the most important factor in the total nitrogen equation $\left(R^{2}\right.$ proportion $\left.=24 \%\right)$ and very important in explaining nitrate-nitrogen $(11 \%)$ and total suspended solids $(14 \%)$ loss, while not as important in the ammonia-nitrogen $(7 \%)$ and total phosphorus $(9 \%)$ equations. The negative sign indicates, as expected, that buffer efficiency and slope angle are inversely related. In all but the total suspended solids equation, theta takes the form of a second-order polynomial. The nonlinearity of the slope variable indicates that shallow slopes differ greatly from steep slopes with regard to filtering capacity, but the difference between two steep slopes is minimal.

Manning's roughness coefficient entered into four equations as a second-order polynomial, except in one case. It was consistently important in explaining variation in the dependent variable, but was the most important parameter for only the nitrate-nitrogen equation, where it accounted for $18 \%$ of the variation. It was moderately important in the ammonia-nitrogen model, accounting for 10 to $13 \%$ of the variation. Again, the positive sign indicates a direct relationship, as was expected.

Permeability was important in describing variability in five of the equations, usually as second-order polynomial functions. Permeability was important in the nitrate (11\%), total phosphorus (19\%), and total suspended solids (29\%) models. The signs of the coefficient estimates vary for the different dependent variables. In the ammonia- and nitrate-nitrogen equations, the relationship is direct, while it is inverse for total nitrogen, phosphurus, and suspended solids. Phillips (1989a) described a similar phenomenon and offered the following explanation:

High [hydraulic] conductivity tends to enhance buffer effectiveness in that it allows surface water to be infiltrated. But higher permeability tends to reduce buffer effectiveness in that it allows for rapid throughflow in the saturated zone.

It is apparent that the relationship between permeability and trapping efficiencies is complicated and that an explanation for the observed relationships is difficult.

Mean particle diameter (MPD) appeared in the total nitrogen, phosphorus, and solids equations and was moderately important in explaining variability in each. The inverse relationship is difficult to explain. The interactive variable of distance and theta enters into two equations. The distance-theta factor accounted for $17 \%$ of the variation in total phosphoius and only $3 \%$ for total nitrogen. 


\subsubsection{Concentration-regression models}

As was done in the mass-regression models, distance was included in each equation even though it did not explain much of the variation in the dependent variable in some cases. For ammonia-nitrogen, distance was not very important in explaining variation in percent reduction (10\%). However, in the nitrate and total nitrogen equations, distance was the most important parameter $\left(R^{2}\right.$ proportion $=36$ and $53 \%$, respectively).

Additionally, distance was an important factor in explaining trapping efficiencies of total suspended solids (28\%) and total phosphorus (13\%). The positive sign in each equation indicates, as was expected, that as distance increases so does trapping efficiency. Distance was linearly related to buffer efficiency for total suspended solids and total phosphorus. In two cases (ammonia and nitrate-nitrogen), distance took the form of a second-order polynomial. The more complex function describing the relationship between distance and the dissolved species of nitrogen suggests that there is a threshold distance beyond which there is little change in buffer efficiency. The data suggest that this is at least below $90 \mathrm{~m}$ for ammonia and $36 \mathrm{~m}$ for nitrate (Appendix B).

Theta entered all equations, indicating that slope is important in every case. Slope was the most important factor in the total phosphorus and total suspended solids equations $\left(R^{2}\right.$ proportion $=50$ and $49 \%$, respectively). It was moderately important in explaining total nitrogen loss $(28 \%)$, while not very important in the ammonia-nitrogen $(10 \%)$ and nitrate-nitrogen $(4 \%)$ equations. The negative sign indicates, as was expected, that buffer efficiency and slope angle are inversely related. Theta takes the form of a second-order polynomial in all equations. Again, as with the mass-regression equations, there appears to be a threshold slope for filtering capacity. This threshold is at least less then a $16 \%$ slope.

Manning's roughness coefficient entered into three equations (ammonia and total nitrogen and total phosphorus) with the nitrogen species equations having a second-order polynomial form. Roughness explained 8,5 , and $13 \%$ of the variation in ammonia, total nitrogen, and total phosphorus, respectively. The negative sign, indicating an inverse relationship, is the opposite of what was expected.

Permeability was important in describing variability in four equations, two as second-order polynomial functions. Permeability was the dominant factor for ammonia $(11 \%)$ but not by much. It was moderately important in the total nitrogen equation $(18 \%)$ and not important in the total phosphorus model $(3 \%)$, although, as an interactive term with distance, it helped to account for $15 \%$ of the variability in buffer efficiency for total phosphorus. Permeability was inversely related to buffering efficiency in each case.

MPD entered into all but the total nitrogen equations. It was a relatively insignificant factor in all but the total phosphorus equation, where it accounted for $34 \%$ of the variability. MPD was directly related to filtering phosphorus, but inversely related to the other dependent variables. This occurs because of preferential adsorption of phosphorus to clay particles, which are small. 
Results from the mass and concentration data analyses provide some interesting insights when compared with each other and with a more theoretically based model. First, regardless of the data set, the physical parameters used as independent variables appear to be important in explaining filtering capacities of buffer strips. Which factors are most important varies both for the different constituents being modeled and for the method of data reporting (mass or concentration). For instance, the concentration equations generally contain one or two explanatory variables that account for the majority of the variation in the dependent variable, while the mass equations usually contain three or four variables that explain around $10-20 \%$ each the variation in the dependent variable. Tests of Phillips' (1989 a, b) theoretically derived models [Eqs. (1.1) and (1.2)], suggest that for substances whose delivery is related to stream power, such as phosphorus, sediment, and to some extent, total nitrogen, slope and permeability are the most important factors in determining buffer efficiency. For dissolved substances like ammonia and nitrate nitrogen, whose filtering characteristics are more tied to detention time, the ability to explain filtering efficiency is dominated by distance of flow. The results from the concentration data set analysis confirm Phillips' results. However, the mass data set analysis does net follow the same pattern at all. One explanation as to why the concentration models behave like Phillips' models and why the mass models do not is that Phillips' models were based on hydrologic equations. The concentration records, by their very nature (mass/volume), account for hydrology, while in the mass data, hydrology has been systematically removed. The mass equations are, in a sense, normalized for varying hydrologic conditions and would not be expected to behave like hydrologically derived models.

It must be noted again that the models described here are limited by the ranges of the variables and the study data used to develop them. As new research provides more data records, such models would change both in estimated coefficients and in the range of applicability.

\subsubsection{Determination of effective buffer strip length}

The form of the linear equations in Tables 3.1 and 3.2 results in values representing trapping efficiencies, not delivery ratios. The equations were left in this form to provide models that allow managers to determine effective buffer strip length. If a

manager knows the conditions of the area of concern and the approximate effectiveness of the filter strip that is required, the necessary distance is a simple calculation. Resulting values from these equations can be subtracted from 100 and divided by 100 to obtain delivery ratios.

\subsubsection{Nonlinear Equations}

\subsubsection{Models}

The three modcls resulting from the NLIN procedure for total phosphorus, total nitrogen, and total suspended solids, respectively, are 


$$
\begin{gathered}
61 \\
T P_{\text {trapped }}=1 /\left(1+\mathrm{e}^{(1.47-0.416 d+0.012 s q r d+0.296 p-5.74 n)}\right), \\
T N_{\text {trapped }}=1 /\left(1+\mathrm{e}^{(-10.14+0.016 d+26.830-4.58 \ln (n)+2.87 \ln (m p d)+1.47 d n-1.63 d \theta)}\right), \text { and } \\
T S S_{\text {trapped }}=1 /\left(1+\mathrm{e}^{(-3.57-0.33 d+0.011 \text { sqrd }+22.82 \theta+0.73 p)}\right),
\end{gathered}
$$

where

$$
\begin{array}{lll}
T P & = & \text { percent total phosphorus trapped, } \\
T N & = & \text { percent total nitrogen trapped, } \\
T S S & = & \text { percent total suspended solids trapped, } \\
d & = & \text { distance of flow }(\mathrm{m}) \\
\text { sqrd } & = & \text { distance of flow squared, } \\
p & = & \text { soil permeability (in./hr) } \\
n & = & \text { Mannings' roughness coefficient, } \\
m p d & = & \text { soil mean particle diameter }(\mathrm{mm}) \\
\theta & = & \text { theta, slope angle, } \\
\text { ln } & = & \text { natural log. }
\end{array}
$$

Equations $(3.4-3.6)$ are used to calculate trapping efficiency in each cell of the Ray Roberts data base. The trapping efficiency was subtracted from 100 to obtain delivery ratios in the form of percentages. These three models were tested with the Timber Creek watershed data. The models produced numbers in the range between 0 and 100 and were considered useful for application to the overall loading models.

The three nonlinear models have different variables for each pollutant than do the linear forms because, during development of the regression equations, the criteria were not always met when the variables from the linear models were used. The model selection procedure was performed again to obtain Eqs. $(3.4$ - 3.6).

In the nonlinear form, the total phosphorus and total suspended solids models required fewer variables. The total phosphorus model only required distance, permeability, and Manning's roughness coefficient. The reduction in the number of explanatory variables means that each variable in a model explains more of the variance in the dependent variable. Permeability is important in both the total phosphorus and total suspended solids models; this finding is more consistent with Phillips' conclusions than are the linear models for these pollutants. Slope is also important in the total suspended solids model, a finding which is also consistent with Phillips' models. Manning's roughness coefficient is important for both the linear and nonlinear equations for total phosphorus; this is not consistent with Phillips' conclusions. The nonlinear total nitrogen model is similar to the linear form with respect to the variables that were included. 


\subsubsection{Sensitivity Analysis}

Total phosphorus. The total phosphorus delivery model was most sensitive to Manning's roughness coefficient and permeability (Fig. 3.1). The lowest total phosphorus delivery was $5 \%$, whereas Manning's roughness coefficient equalled 0.4 and permeability equalled $0.06 \mathrm{in} . / \mathrm{h}$. The highest total phosphorus delivery ratio was $65 \%$, whereas Manning's roughness coefficient was 0.05 and permeability was $5.00 \mathrm{in} . / \mathrm{h}$. The inverse relationship between delivery ratio and Manning's roughness coefficient was expected. A "rougher" surface reduces flow velocity and increases sediment deposition. Phosphorus attached to sediment would, therefore, be trapped more effectively in a rougher surface.

The effect of permeability on delivery ratio for total phosphorus was not expected from a hydrologic viewpoint. Increases in permeability would reduce overland flow and the ability to carry sediment-bound phosphorus. This process would manifest itself as an inverse relationship between total phosphorus and permeability. The direct relationship that was observed (Fig. 3.1) can be explained, however. Permeability may be acting as a surrogate for soil texture. Permeability values were assigned to soils based on textural descriptions of each soil. The finer soils, clays and clay loams, were assigned low permeability values and sands were assigned high permeability values. Clay soils trap phosphorus more efficiently than do sandy soils and, therefore, have a lower delivery ratio.

Total nitrogen. Slope, Manning's roughness coefficient, and MPD all influenced the delivery ratio of total nitrogen (Fig. 3.2). Values range from 1 to $100 \%$ delivery. The lowest delivery ratios occurred when Manning's roughness coefficient and MPD were low. The highest delivery ratios occurred when Manning's roughness coefficient and MPD were highest. Increases in percent slope had the effect of reducing delivery ratios.

Several unexpected trends resulted from the sensitivity analysis of the total nitrogen delivery ratio model (Fig. 3.2). First, slope had the opposite effect than what was expected. The amount of nitrogen delivered decreased as slope increased. There is no plausible physical explanation for this. However, an explanation does lie in the data set used to create the model. The records with the highest slopes in the data set were also from records at forested plots. The permeability in these plots was very high and resulted in high delivery values. I do not believe the model represents the true influence of slope on the delivery of total nitrogen. This is a limitation of the data set. More studies would help clarify this relationship.

Another unexpected trend in total nitrogen model sensitivity was the effect of Manning's roughness coefficient on the delivery ratio. Increases in Manning's roughness coefficient generally resulted in an increase in the delivery ratio, which was not expected. In fact, the highest value of $n(0.4)$ always resulted in the highest delivery ratio regardless of slope or MPD. One explanation for this trend is that forested areas, with a roughness coefficient of 0.4 , also have high hydraulic conductivity because of macropore development in the root zone. Higher hydraulic conductivities indicate that subsurface flow rates are high. Because nitrogen is transported in subsurface and surface flow, high delivery ratios rcsult. Manning's roughness coefficient may be acting as a metric for hydraulic conductivity. 


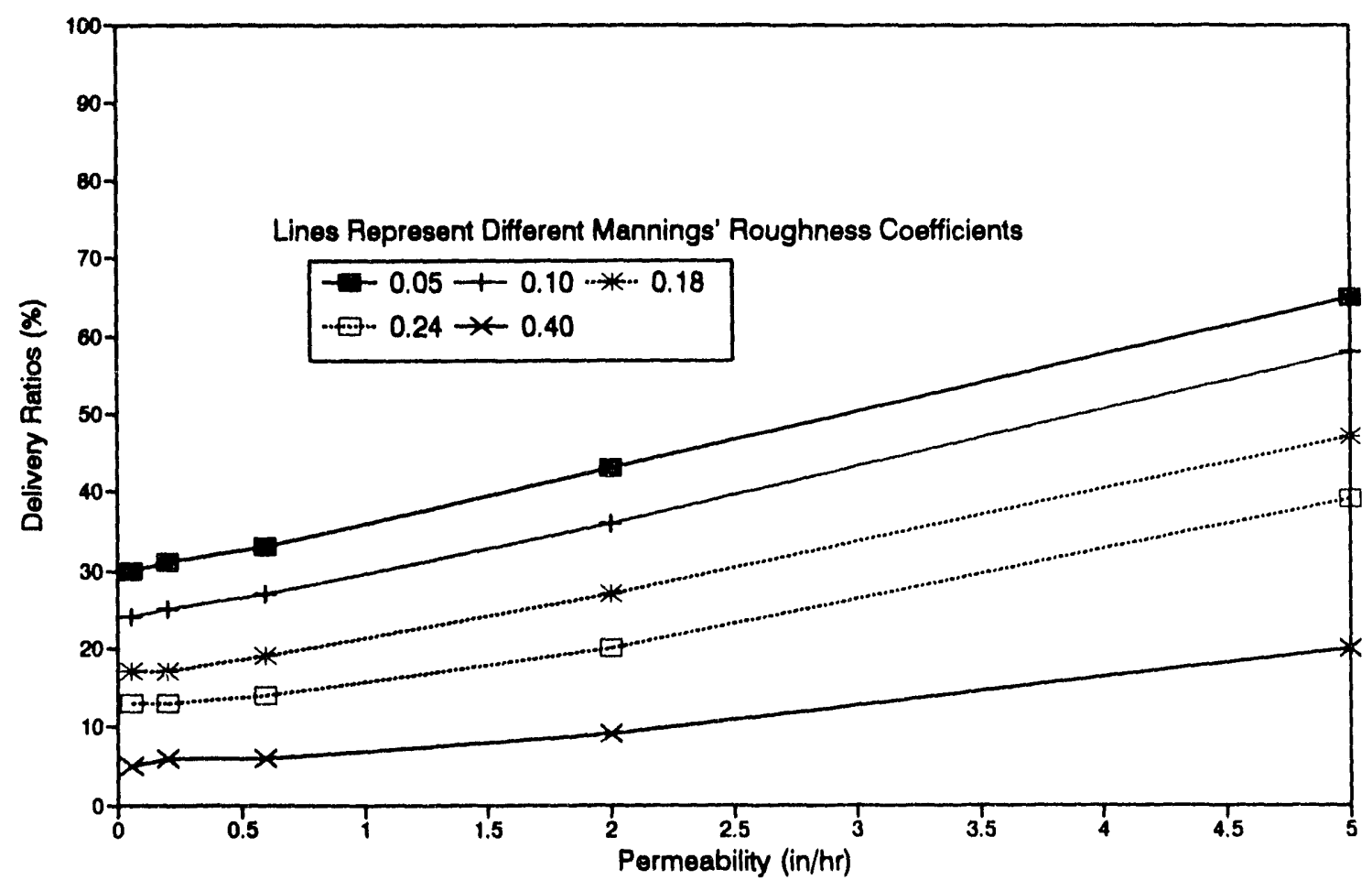

Fig. 3.1. Sensitivity analysis of nonlinear total phosphorus model. 

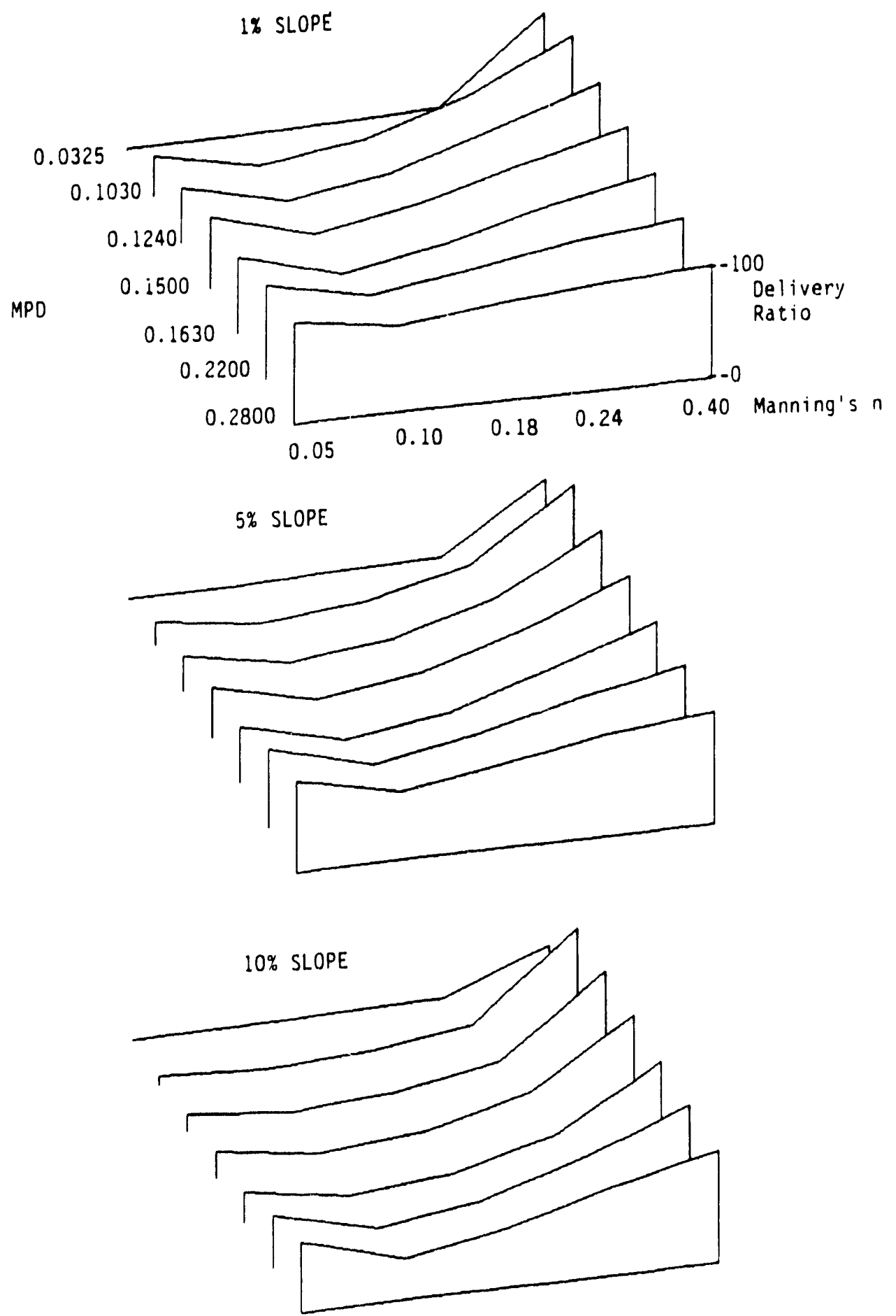

Fig. 3.2. Sensitivity analyisis of nonlinear total nitrogen model. 
The trend in the effect of MPD and delivery ratio further supports this explanation. When MPD was at $0.0325 \mathrm{~mm}$, the delivery ratio approached 0 , except when $n$ was 0.4 . An MPD of 0.0325 means the soil is mostly clay. Subsurface flow rates in clay are minimal, meaning any total nitrogen delivery would occur from surface flow. The fact that there is delivery in clay soils with forest-land use suggests that macropores may be an important route for total nitrogen delivery. Delivery ratios for total nitrogen increased up to $80 \%$, with an increase in MPD to 0.1030 . Smaller increases in the delivery ratio toward $100 \%$ occurred as the MPD approached 0.280 . MPD gives an indication of hydraulic conductivity, with higher MPD suggesting higher hydraulic conductivity. Permeability did not enter into the model for total nitrogen delivery because of collinearity problems with other variables.

Total suspended solids. Slope and soil permeability were the dominant influences on the delivery ratios for total suspended solids (Fig. 3.3). Delivery ratios ranged from $3 \%$, when slope was below $2.5 \%$ and permeability was 0.06 in./h, to $89 \%$ with a $10 \%$ slope and a permeability of $5.0 \mathrm{in} . / \mathrm{h}$. The increase in delivery ratio with an increase in slope was expected. Water velocity increases as slope increases; therefore, the ability of the water to transport sediment increases. The increase in delivery with increase in permeability is connter-intuitive, however. A high permeability would reduce the rate and volume of overland flow. This would, in turn, reduce the sediment-carrying capacity and should result in lower delivery of sediment. This observed trend may be explained by the source of the data used to develop the models. Several studies used for this analysis were from feedlot runoff studies with high organic solid loads. Organic solids would tend to settle out with the finer particles associated with soils with low permeability and would stay in solution longer than course grained sandy soils with higher permeabilities.

\subsubsection{Limits on all models}

The sensitivity analysis points out two critical aspects of interpreting regression equations. First, the resulting models are generally only useful within the ranges of the data used to create them. These models should not be used with variable values outside of their specified ranges (Tables 3.3 - 3.4). Doing so could result in large errors, particularly with equations using square transformed versions of the variables. In lieu of new data records to extend the limit of these models, variables outside these limits could be set to the minimum or maximum value depending on whether the actual value is above or below the model limits. Second, regression analysis quantifies only correlations between "explanatory" variables and the dependent variables. These correlations do not prove cause-and-effect relationships. Often, explanatory variables act as surrogates for other variables that are not in the model but that are responsible for changes in the dependent variable. 


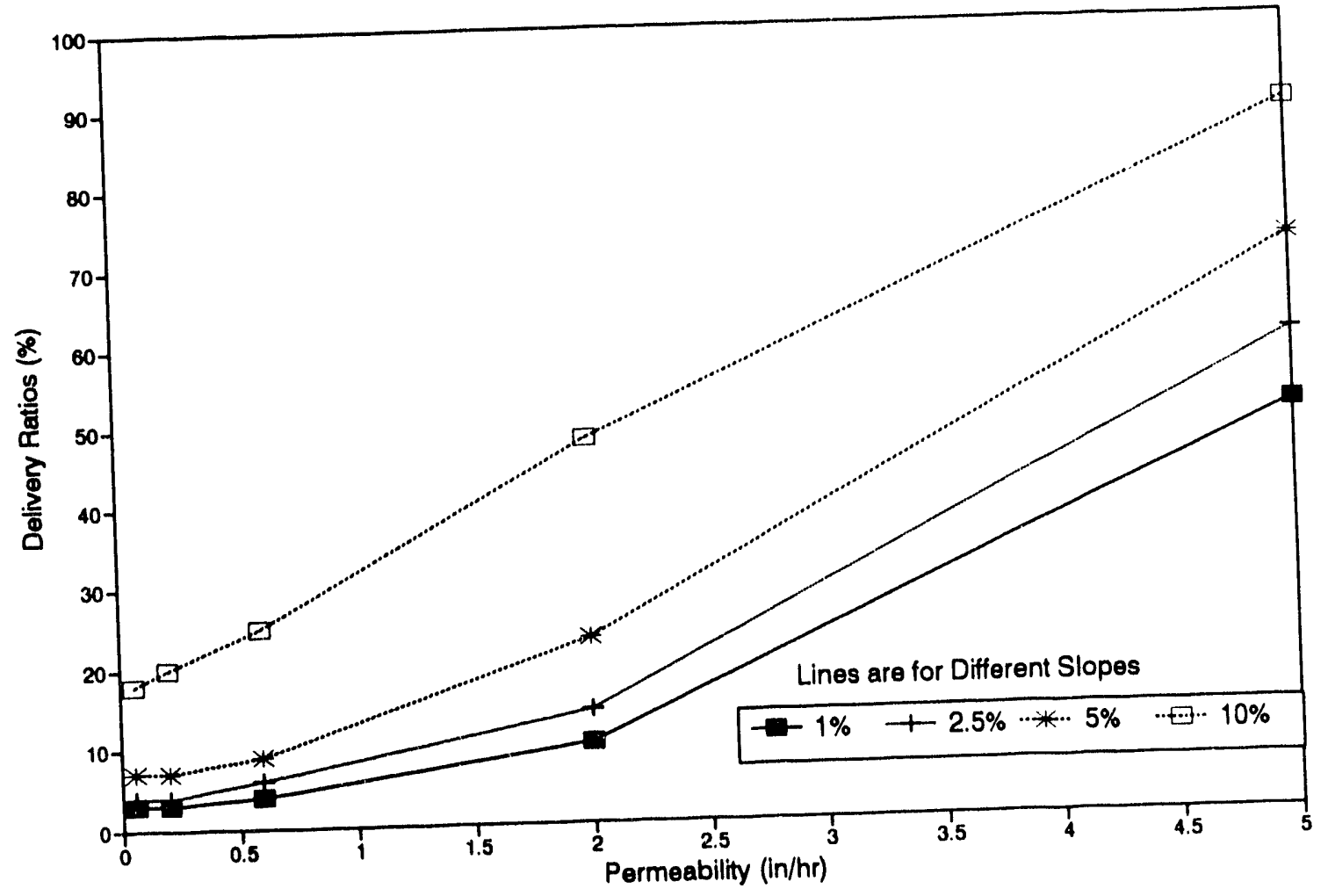

Fig. 3.3. Sensitivity analysis of nonlinear total suspended solids model. 
Table 3.3. Minimum and maximum limits of data used to develop the linear models for vegetated filter-strip-trapping efficiency for mass of ammonia nitrogen (A), nitrogen (B), total nitrogen (C), total phosphorus (D), and total suspended solids (E)

\begin{tabular}{|c|c|c|c|}
\hline Parameter & Units & Minimum & Marimum \\
\hline \multicolumn{4}{|c|}{ A. Ammonic nitrogen } \\
\hline Distance & meters & 4.6 & 27.43 \\
\hline Theta & degrees & 0.04 & 0.16 \\
\hline Roughness & unitless & 0.046 & 0.14 \\
\hline Permeability & inches/hour & 0.05 & 2.50 \\
\hline \multicolumn{4}{|c|}{ B. Nitrate nitrogen } \\
\hline Distance & meters & 4.6 & 27.43 \\
\hline Theta & degrees & 0.04 & 0.16 \\
\hline Roughness & unitless & 0.046 & 0.14 \\
\hline Permeability & inches/hour & 0.05 & 2.50 \\
\hline Distance*Theta & & 0.05 & 1.09 \\
\hline \multicolumn{4}{|c|}{ C. Total nitrogen } \\
\hline Distance & meters & 3.8 & 30.50 \\
\hline Theta & degrees & 0.04 & 0.35 \\
\hline Roughness & unitless & 0.046 & 0.40 \\
\hline Permeability & inches/hour & 0.05 & 5.00 \\
\hline MPD & millimeters & 0.0726 & 0.3250 \\
\hline Distance*Theta & & 0.14 & 10.81 \\
\hline \multicolumn{4}{|c|}{ D. Total phosphorus } \\
\hline Distance & meters & 0.5 & 30.50 \\
\hline Theta & degrees & 0.03 & 0.335 \\
\hline Roughness & & 0.046 & 0.40 \\
\hline Permeability & inches/hour & 0.05 & 5.00 \\
\hline MPD & millimeters & 0.0726 & 0.3250 \\
\hline Distance*Theta & & 0.41 & 10.80 \\
\hline \multicolumn{4}{|c|}{ E. Total suspended solids } \\
\hline Distance & meters & 4.6 & 27.43 \\
\hline Theta & degrees & 0.03 & 0.16 \\
\hline MPD & millimeters & 0.0726 & 0.3250 \\
\hline Permeability & inches/hour & 0.05 & 5.00 \\
\hline
\end{tabular}


Table 3.4. Minimum and maximum limits of data used to develop the linear models for vegetative filter-strip-efficiency for concentration of ammonia nitrogen (A), nitrate nitrogen (B), total nitrogen (C), total phosphorus (D), and total suspended solids (E)

\begin{tabular}{|c|c|c|c|}
\hline Parameter & Units & Minimum & Maximum \\
\hline \multicolumn{4}{|c|}{ A. Ammonia nitrogen } \\
\hline Distance & meters & 4.6 & 91.0 \\
\hline Theta & degrees & 0.005 & 0.16 \\
\hline Roughness & unitless & 0.03 & 0.14 \\
\hline Permeability & inches/hour & 0.80 & 5.00 \\
\hline MPD & millimeters & 0.0726 & 0.1670 \\
\hline \multicolumn{4}{|c|}{ B. Nitrate nitrogen } \\
\hline Distance & meters & 3.0 & 36.0 \\
\hline Theta & degiees & 0.04 & 0.16 \\
\hline MPD & millimetcrs & 0.0726 & 0.1670 \\
\hline \multicolumn{4}{|c|}{ C. Iotal nitrogen } \\
\hline Distance & meters & 3.0 & 91.0 \\
\hline Theta & degrees & 0.0015 & 0.16 \\
\hline Roughness & unitless & 0.03 & 0.14 \\
\hline Permeability & inches/hour & 0.80 & 5.00 \\
\hline \multicolumn{4}{|c|}{ D. Total phosphorus } \\
\hline Distance & meters & 3.0 & 36.0 \\
\hline Theta & degrees & 0.0005 & 0.16 \\
\hline Roughness & unitless & 0.03 & 0.14 \\
\hline Permeability & inches/hour & 0.0 .5 & 5.00 \\
\hline MPI & millimeters & 0.0726 & 0.1670 \\
\hline Distance ${ }^{\star}$ Roughness & & 0.021 & 5.04 \\
\hline Distance * Permeability & & 1.30 & 180.00 \\
\hline \multicolumn{4}{|c|}{ I?. Total suspended scticks } \\
\hline Distance & meters & 0.61 & 91.0 \\
\hline Theta & degrees & 0.005 & 0.16 \\
\hline MPD & millimeters & 0.0726 & 0.1030 \\
\hline Permeability & inches/hour & 0.80 & 2.50 \\
\hline
\end{tabular}




\subsection{POTENTIAL LOAD ESTTMATION}

To establish the validity of using export coefficients as potential load estimates, I compared the annual loads as estimated from potential values only with observed annual loads (Table 3.5). The total phosphorus and total nitrogen estimates were calculated by multiplying the export coefficients for each land-use type by the total area of each land use. This is the standard method for use of export coefficients. The total phosphorus annual load estimates were all at least an order of magnitude higher than the observed loads. Total nitrogen load estimates were at least twice as high as the observed annual loads.

The overestimations by the export coefficients alone indicated that these coefficients were not sufficient to model nutrient loading from large areas. While the export coefficients were specifically selected from studies of areas with conditions similar to conditions in the Ray Roberts watershed, the studies were of small plots and thus do not represent loading from large areas. However, treating these export coefficients as estimates of potential loading, just as the USLE is used to calculate potential sediment yield, enables them to be used at larger scales by multiplying them by delivery ratios.

\subsection{MODEL CALIBRATION}

\subsubsection{Eastern Cross Timbers Physiographic Region}

The COUNT threshold resulting in the best agreement between estimated and observed loads was different for each region. The Timber Creek watershed was used to calibrate the models for the Cross Timbers region. Calibration started with a COUNT threshold of 200 , which approximates the 7.5 minute blue line streams, or base flow conditions. The threshold was reduced to 100,15 , and finally 10 before a calibration threshold for all three pollutants was identified (Figs. 3.4 - 3.6). While good matches between observed load and estimated loads of total phosphorus and total nitrogen were obtained using a COUNT threshold of 15 , the estimate for total suspended solids load was $40 \%$ higher than the observed load. Nevertheless, 15 was chosen for the COUNT threshold value for watersheds in the Cross Timbers region.

\subsubsection{Blackland Prairic Physiographic Region}

The Buck Creek watershed was used to calibrate the models in the Blackland Prairie region. This watershed calibrated at a COUNT threshold of five. Estimates of total phosphorus and total nitrogen loads were close to observed loads, while the estimate for total suspended solids was 1.58 times higher than the observed value. 
Table 3.5. Total annual observed and estimated loads calculated from potential loads only.

\begin{tabular}{|c|c|c|c|c|}
\hline Watershed & & $\begin{array}{c}\text { Total } \\
\text { phosphorus } \\
\text { (kg/year) }\end{array}$ & $\begin{array}{c}\text { Total nitrogen } \\
\text { (kg/year) }\end{array}$ & $\begin{array}{c}\text { Total suspended } \\
\text { solids } \\
\text { (kg/year) } \\
\end{array}$ \\
\hline \multicolumn{5}{|c|}{ Cross Timbers watersheds } \\
\hline \multirow[t]{3}{*}{ Timber Creek } & Observed & $2.78 \times 10^{3}$ & $1.67 \times 10^{4}$ & $9.37 \times 10^{5}$ \\
\hline & Estimated & $1.29 \times 10^{4}$ & $5.94 \times 10^{4}$ & $6.23 \times 10^{6}$ \\
\hline & \% Difference & 364 & 256 & $564-$ \\
\hline \multirow[t]{3}{*}{ Indian Creek } & Observed & $2.68 \times 10^{3}$ & $1.68 \times 10^{4}$ & $1.37 \times 10^{6}$ \\
\hline & Estimated & $1.13 \times 10^{4}$ & $5.78 \times 10^{4}$ & $6.51 \times 10^{6}$ \\
\hline & $\%$ Difference & 321 & 244 & 375 \\
\hline \multirow[t]{3}{*}{ Wolf Creek } & Observed & $1.27 \times 10^{2}$ & $2.69 \times 10^{3}$ & $7.80 \times 10^{4}$ \\
\hline & Estimated & $4.93 \times 10^{3}$ & $2.23 \times 10^{4}$ & $2.53 \times 10^{6}$ \\
\hline & $\%$ Difference & 3782 & 729 & 3243 \\
\hline \multirow[t]{3}{*}{ IDB1 } & Observed & $4.83 \times 10^{4}$ & $3.04 \times 10^{5}$ & $2.56 \times 10^{7}$ \\
\hline & Estimated & $1.08 \times 10^{5}$ & $4.76 \times 10^{5}$ & $7.34 \times 10^{7}$ \\
\hline & $\%$ Difference & 123 & 57 & 187 \\
\hline \multicolumn{5}{|c|}{ Grand Prairie watersheds } \\
\hline \multirow[t]{3}{*}{ Spring Creek } & Observed & $8.86 \times 10^{3}$ & $5.13 \times 10^{4}$ & $2.49 \times 10^{6}$ \\
\hline & Estimated & $2.54 \times 10^{4}$ & $1.06 \times 10^{5}$ & $1.88 \times 10^{7}$ \\
\hline & $\%$ Difference & 187 & 107 & 655 \\
\hline \multirow[t]{3}{*}{ TR4 } & Observed & $2.03 \times 10^{4}$ & $9.76 \times 10^{4}$ & $1.73 \times 10^{6}$ \\
\hline & Estimated & $6.98 \times 10^{4}$ & $2.93 \times 10^{5}$ & $1.07 \times 10^{8}$ \\
\hline & $\%$ Difference & 244 & 200 & 6085 \\
\hline \multirow[t]{3}{*}{ TR3 } & Observed & $2.72 \times 10^{4}$ & $1.52 \times 10^{5}$ & $4.33 \times 10^{6}$ \\
\hline & Estimated & $9.93 \times 10^{4}$ & $4.20 \times 10^{5}$ & $1.74 \times 10^{8}$ \\
\hline & \% Difference & 265 & 176 & 3918 \\
\hline \multirow[t]{3}{*}{ TR2 } & Observed & $3.36 \times 10^{4}$ & $2.24 \times 10^{5}$ & $1.13 \times 10^{7}$ \\
\hline & Estimated & $1.08 \times 10^{5}$ & $4.57 \times 10^{5}$ & $1.80 \times 10^{8}$ \\
\hline & $\%$ Difference & 221 & 104 & 1493 \\
\hline \multirow[t]{3}{*}{ TR1 } & Observed & $3.78 \times 10^{4}$ & $2.78 \times 10^{5}$ & $1.30 \times 10^{7}$ \\
\hline & Estimated & $1.43 \times 10^{5}$ & $6.03 \times 10^{5}$ & $2.07 \times 10^{8}$ \\
\hline & $\%$ Difference & 278 & 117 & 1492 \\
\hline \multicolumn{5}{|c|}{ Blackland Prairie watersheds } \\
\hline \multirow[t]{3}{*}{ Buck Creek } & Observed & $8.55 \times 10^{3}$ & $3.89 \times 10^{4}$ & $3.64 \times 10^{6}$ \\
\hline & Estimated & $1.57 \times 10^{4}$ & $6.49 \times 10^{4}$ & $1.16 \times 10^{7}$ \\
\hline & \% Difference & 84 & 67 & 219 \\
\hline \multirow[t]{3}{*}{ IDB3 } & Observed & $2.32 \times 10^{4}$ & $1.62 \times 10^{5}$ & $1.44 \times 10^{7}$ \\
\hline & Estimated & $5.65 \times 10^{4}$ & $2.47 \times 10^{5}$ & $3.92 \times 10^{7}$ \\
\hline & \% Difference & 144 & 52 & 172 \\
\hline \multirow[t]{3}{*}{ IDB2 } & Observed & $3.33 \times 10^{4}$ & $2.12 \times 10^{5}$ & $1.85 \times 10^{7}$ \\
\hline & Estimated & $7.35 \times 10^{4}$ & $3.18 \times 10^{5}$ & $5.15 \times 10^{7}$ \\
\hline & $\%$ Difference & 121 & 50 & 178 \\
\hline
\end{tabular}




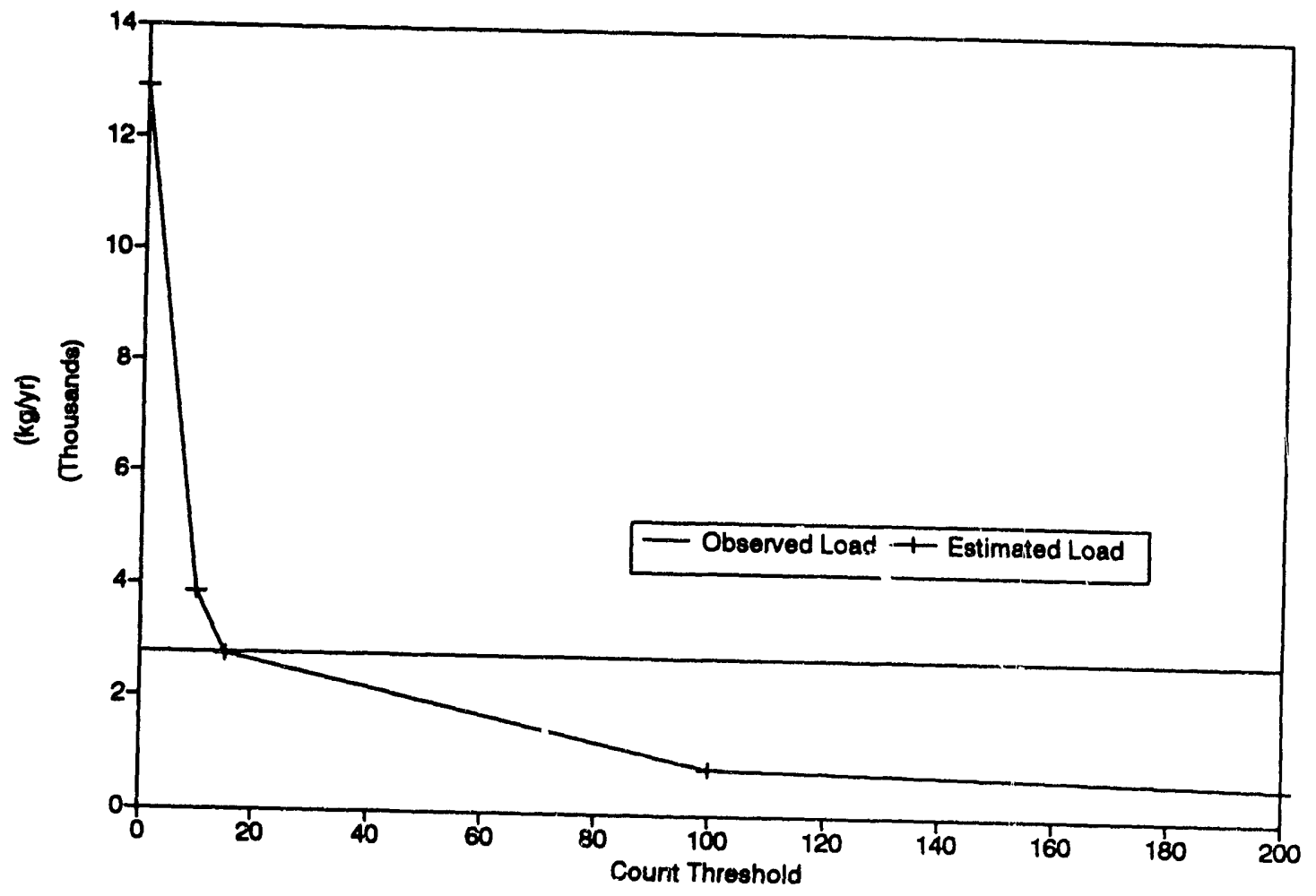

Fig. 3.4. Calibration of the model in Timber Creek waiershed for total phosphorus load. 


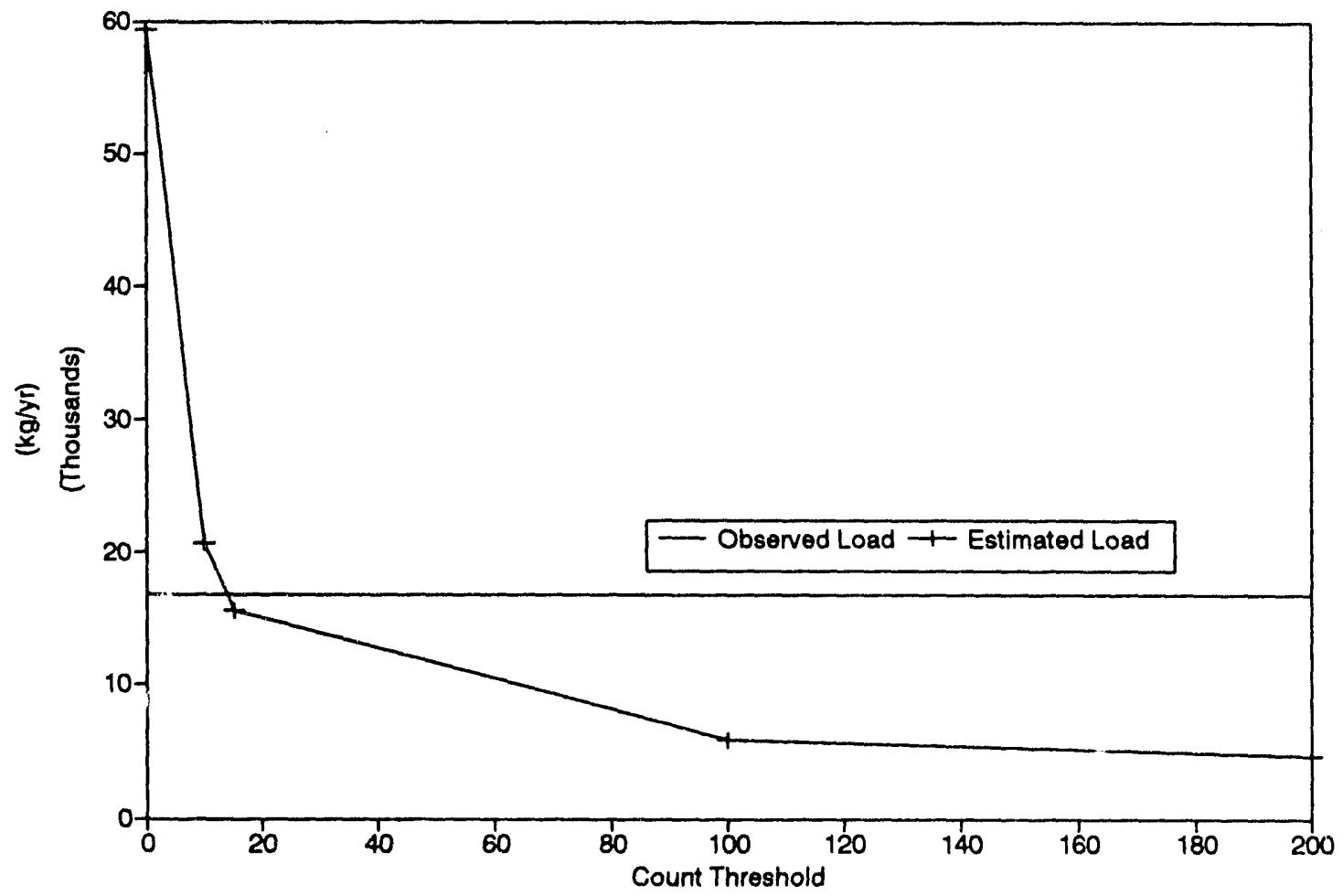

Fig. 3.5. Calibration of the model in Timber Creek watershed for total nitrogen load. 
73

ORNL-DWG 92-14883

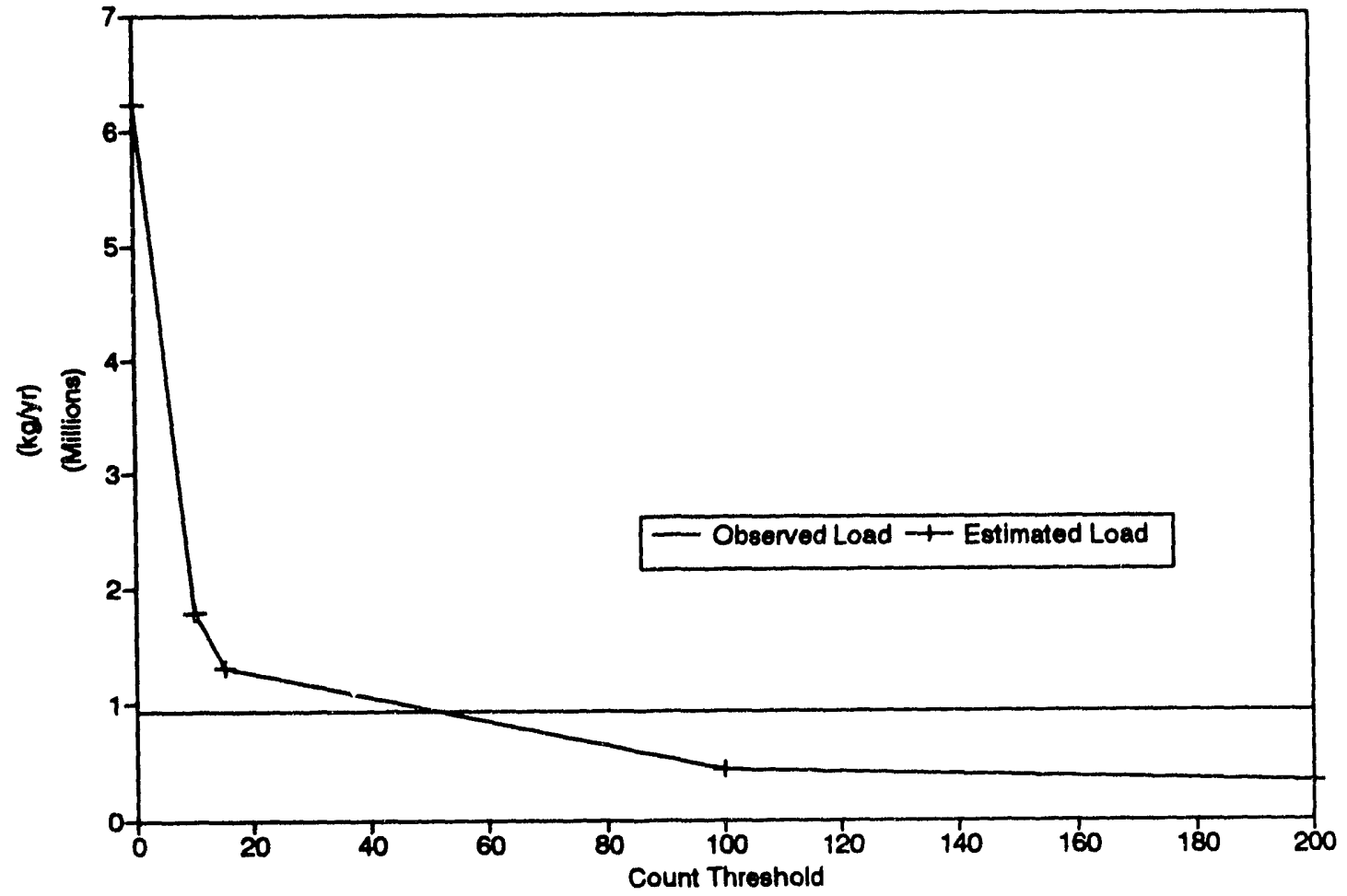

Fig. 3.6. Calibration of the model in Timber Creek watershed for total suspended solids load. 


\subsubsection{Grand Prairic Physiographic Region}

The Spring Creek watershed was used as the calibration watershed for the models in the Grand Prairie region. The model calibrated to a COUNT threshold of eight with a good match between observed total phosphorus load and estimated load. However, estimates of total nitrogen were $30 \%$ too low and for total suspended solids $150 \%$ too high. Because this calibration result was not as good as results for the other regions, the TR4 watershed was alternatively used as a calibration watershed. Again, a COUNT threshold value of eight resulted in the best match for all three pollutants; therefore, the Grand Prairie watersheds were all run using a COUNT threshold of eight to define the stream network.

An interesting comparison can be made between the dominant soil texture in the physiographic regions and the COUNT thresholds to which the models calibrated for these regions. The watersheds calibrated along a continuum of soil textures. The Cross Timbers region, which is dominated by the course-grained sands and sandy loams, calibrated to a COUNT value of 15 . The Grand Prairic region watersheds, dominated by clay loams and clays, calibrated to a value of eight. The Blackland Prairie region watersheds calibrated to a COUNT threshold of five; these watersheds are dominated by silty clays and clays, which are the finest textural classes.

Permeability is high in the sandy watersheds; therefore, overland flow would not occur often, and even when it did, it would be limited spatially and temporally. The stream networks would be relatively small, and less of the watershed would contribute to the total load of the pollutant. The Cross Timbers region has sandy soils, and a COUNT value of 15 was required to define the stream network. As a watershed has a higher proportion of clay soils, permeability decreases and overland flow increases. The Blackland Prairie Region is dominated by clays, and a COUNT value of five was adequate to define the stream network. The Grand Prairie region is characterized by mixed sandy and clay loams, and the COUNT threshold required to define the stream network was eight. Thus, watersheds in the three regions calibrated along a continuum of soil texture. The use of the COUNT threshold as a calibration tool appears to successfully model this phenomenon.

Calibration of the models provided some insight about sensitivity to the COUNT threshold. In general, decreasing the COUNT threshold from 15 to 5 approximately doubled the estimated load for all three pollutants. Because the values in the COUNT file for any watershed have an approximate log-normal distribution, this is not a linear relationship across the range of COUNT values. As the COUNT threshold is increased, the total area of the watershed contributing pollutant load decreases but approaches a minimum limit asymptotically.

Using the COUNT threshold to model a drainage network growth during storm events provides a useful way to visualize the hydrologic process (Fig. 3.7) Starting with a COUNT threshold of 200, which approximates the baseflow stream network, the stream network grows in a linear paticin as the COUNT threshold drops to 100. Cells contributing storm water flow are linear extensions of the existing streams in the same direction. The total length of stream added by this drop in threshold is relatively small. 
Count Threshold
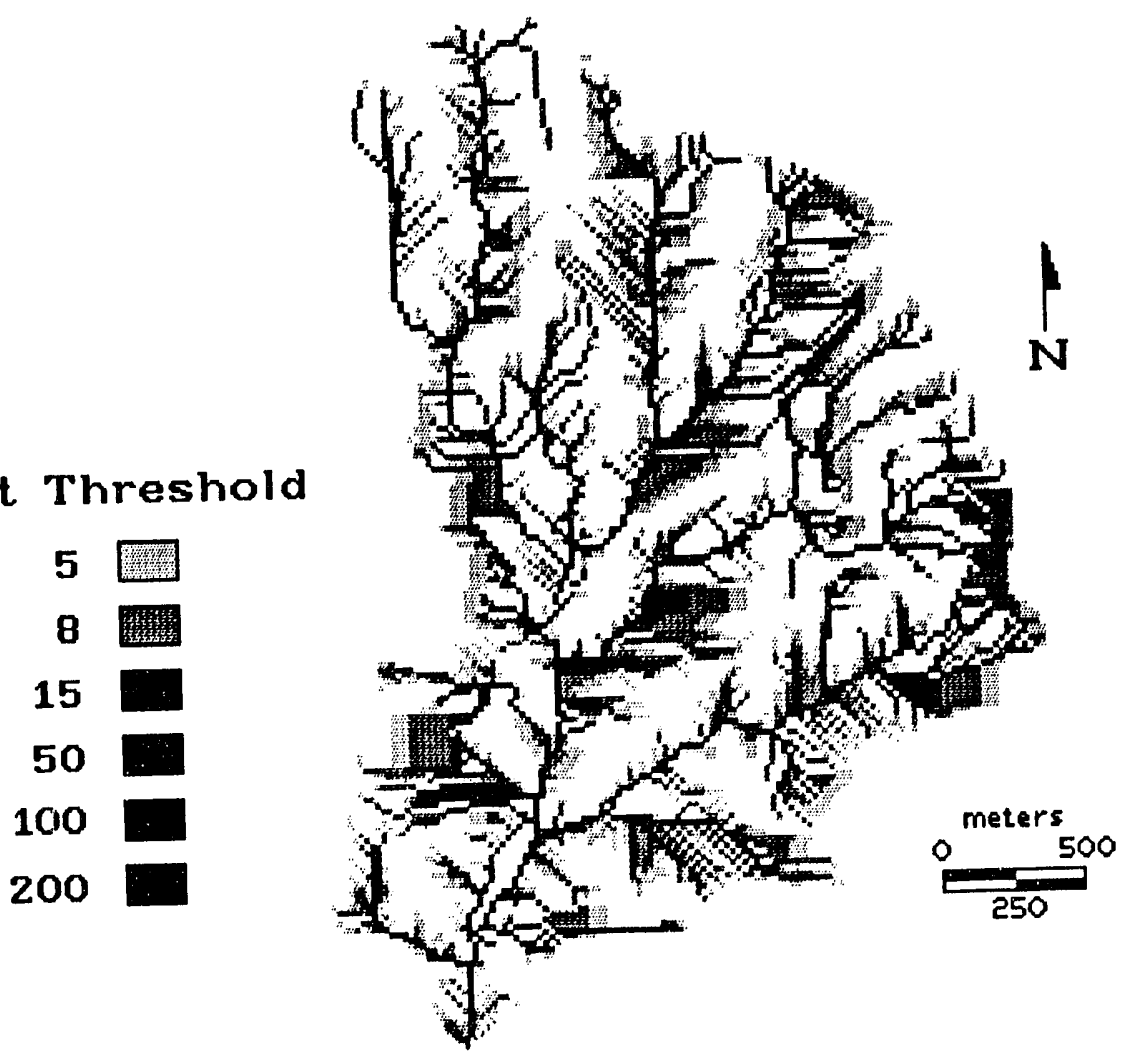

Fig. 3.7. Gray-shade representation of the stream network as delineated from the COUNT program for a small portion of the Timber Creek watershed using six different COUNT thresholds. 
This explains why little improvement in model load estimates was made with this threshold change during calibration (Figs. 3.4 - 3.6). When the threshold was dropped to 15, the drainage network grew both linearly and laterally (Fig. 3.7). This represents the activation of both ephemeral streams and areas adjacent to the stream where overland flow occurs as a result of concentrating subsurface flows. As the COUNT threshold is dropped to five, the growth of hydrologically active cells is almost entirely lateral. This hydrologic process has been described by Hewlett and Hibbert (1967), and Hibbert and Troendle (1988), among others.

The hydrologic sensitivity of the model provides a mechanism for incorporating hydrologic responses to climate change into the model. The models were calibrated to the observed values from the 1985-1986 water year, which was a medium rainfall year. The models could be calibrated to represent low and high rainfall years, provided the water quality data were available. With this capability, one could also test the relative importance of climate change vs land-use change on water quality. This would be accomplished simply by changing the COUNT thresholds to mimic climate change scenarios and changing the land-use input to reflect possible changes in land-use pattern, which affect the DELIVERY model and potential load file, and estimating the resulting loads.

\subsection{ANNUAL LOAD ESTIMATES}

\subsubsection{Total Phosphorus}

Annual total phosphorus load was the most accurately predicted load of the three pollutants. In eight watersheds the estimated load was within $10 \%$ of the observed load and in six of those watersheds estimates were within $2 \%$ of observed values (Table 3.6). Estimates in three other watersheds (TR1, TR2, and IDB1) were within 11, 12, and 21\% of observed loads, respectively; however, the total phosphorus load estimated from Wolf Creek was 7.26 times higher than the observed load.

Despite the differences between the estimated and observed loads, they did not differ significantly from zero $\left(t_{\mathrm{a}}=0.001, \mathrm{~d}=11=1.107\right)$. This statistic includes the Wolf Creek result, which reduces the power of the test. The $t$-test was calculated by dividing the mean percent difference by the standard error of the percent difference. Because the standard error was very high, when the Wolf Creek data were included, the $t$-statistic was very low. Thus, the null hypothesis could not be rejected. When the Wolf Creek data were dropped from the $t$-test analysis, the hypothesis was rejected, meaning that the ustimated loads and the observed loads were statistically different $\left(t_{\mathrm{a}}=0.01, \mathrm{df}=10=3.22\right)$. However, the percent difference between the estimated total phosphorus load and the observed load is within $5 \%\left(t_{\mathrm{a}}=0.001, \mathrm{df}=10=0.72\right)$. 
Table 3.6. Total annual observed and model estimated loads for all watersheds for total phosphorus, total nitrogen, and total suspended solids

\begin{tabular}{|c|c|c|c|c|}
\hline Watershed & & $\begin{array}{c}\text { Total } \\
\text { phosphorus } \\
\text { (kg/year) }\end{array}$ & $\begin{array}{c}\text { Total } \\
\text { nitrogen } \\
\text { (kg/year) }\end{array}$ & $\begin{array}{c}\text { Total suspended } \\
\text { solids } \\
\text { (kg/year) }\end{array}$ \\
\hline \multicolumn{5}{|c|}{ Cross Timbers watersheds } \\
\hline \multirow[t]{3}{*}{ Timber Creek } & Observed & $2.78 \times 10^{3}$ & $1.67 \times 10^{4}$ & $9.37 \times 10^{5}$ \\
\hline & Estimated & $2.75 \times 10^{3}$ & $1.55 \times 10^{4}$ & $1.31 \times 10^{6}$ \\
\hline & $\%$ Difference & -1 & -7 & 39 \\
\hline \multirow[t]{3}{*}{ Indian Creek } & Observed & $2.68 \times 10^{3}$ & $1.68 \times 10^{4}$ & $1.37 \times 10^{6}$ \\
\hline & Estimated & $2.64 \times 10^{3}$ & $1.97 \times 10^{4}$ & $1.86 \times 10^{6}$ \\
\hline & \% Difference & -1 & 17 & 36 \\
\hline \multirow[t]{3}{*}{ Wolf Creek } & Observed & $1.27 \times 10^{2}$ & $2.69 \times 10^{3}$ & $7.80 \times 10^{4}$ \\
\hline & Estimated & $1.05 \times 10^{3}$ & $6.73 \times 10^{3}$ & $6.07 \times 10^{5}$ \\
\hline & \% Difference & 726 & 150 & 701 \\
\hline \multirow[t]{3}{*}{ IDB1 } & Observed & $4.83 \times 10^{4}$ & $3.04 \times 10^{5}$ & $2.56 \times 10^{7}$ \\
\hline & Estimated & $3.82 \times 10^{4}$ & $1.88 \times 10^{5}$ & $2.62 \times 10^{7}$ \\
\hline & $\%$ Difference & -21 & -38 & 2 \\
\hline \multicolumn{5}{|c|}{ Grand Prairie watersheds } \\
\hline \multirow[t]{3}{*}{ Spring Creek } & Observed & $8.86 \times 10^{3}$ & $5.13 \times 10^{4}$ & $2.49 \times 10^{6}$ \\
\hline & Estimated & $8.86 \times 10^{3}$ & $3.64 \times 10^{4}$ & $6.42 \times 10^{6}$ \\
\hline & $\%$ Difference & 1 & -29 & 158 \\
\hline \multirow[t]{3}{*}{ TR4 } & Observed & $2.03 \times 10^{4}$ & $9.76 \times 10^{4}$ & $1.73 \times 10^{6}$ \\
\hline & Estimated & $2.24 \times 10^{4}$ & $9.60 \times 10^{4}$ & $4.62 \times 10^{7}$ \\
\hline & $\%$ Difference & 10 & -2 & 167 \\
\hline \multirow[t]{3}{*}{ TR3 } & Observed & $2.72 \times 10^{4}$ & $1.52 \times 10^{5}$ & $4.33 \times 10^{6}$ \\
\hline & Estimated & $2.67 \times 10^{4}$ & $1.15 \times 10^{5}$ & $4.98 \times 10^{7}$ \\
\hline & $\%$ Difference & -2 & -24 & 1050 \\
\hline \multirow[t]{3}{*}{ TR2 } & Observed & $3.36 \times 10^{4}$ & $2.24 \times 10^{5}$ & $1.13 \times 10^{7}$ \\
\hline & Estimated & $2.95 \times 10^{4}$ & $1.29 \times 10^{5}$ & $5.19 \times 10^{7}$ \\
\hline & $\%$ Difference & -12 & -43 & 359 \\
\hline \multirow[t]{3}{*}{ TR1 } & Observed & $3.78 \times 10^{4}$ & $2.78 \times 10^{5}$ & $1.30 \times 10^{7}$ \\
\hline & Estimated & $4.15 \times 10^{4}$ & $1.79 \times 10^{5}$ & $5.83 \times 10^{7}$ \\
\hline & \% Difference & 21 & -35 & 348 \\
\hline \multicolumn{5}{|c|}{ Blackland Prairie watersheds } \\
\hline \multirow[t]{3}{*}{ Buck Creek } & Observed & $8.55 \times 10^{3}$ & $3.89 \times 10^{4}$ & $3.64 \times 10^{6}$ \\
\hline & Estimated & $8.45 \times 10^{3}$ & $3.79 \times 10^{4}$ & $6.07 \times 10^{7}$ \\
\hline & $\%$ Difference & -1 & -3 & 1567 \\
\hline \multirow[t]{3}{*}{ IDB3 } & Observed & $2.32 \times 10^{4}$ & $1.62 \times 10^{5}$ & $1.44 \times 10^{7}$ \\
\hline & Estimated & $2.55 \times 10^{4}$ & $1.21 \times 10^{5}$ & $1.72 \times 10^{7}$ \\
\hline & $\%$ Difference & 9 & -25 & 19 \\
\hline \multirow[t]{3}{*}{ IDB2 } & Observed & $3.33 \times 10^{4}$ & $2.12 \times 10^{5}$ & $1.85 \times 10^{7}$ \\
\hline & Estimated & $3.41 \times 10^{4}$ & $1.59 \times 10^{5}$ & $2.34 \times 10^{7}$ \\
\hline & \% Difference & 2 & -25 & 26 \\
\hline
\end{tabular}


There does not appear to be any trend in the error in the estimated total phosphorus loads. The sign of the differences vary; six are positive, and six are negative: this finding indicates that no bias exists in the model (Table 3.6).

The total phosphorus model worked well for all watersheds of this study. Model accuracy for watersheds from the three physiographic regions was about the same; this finding suggests that the model may be effective when applied to other watersheds across the country. There is a slight trend in the model accuracy relative to watershed size. The larger watersheds (TR1, TR2, and IDB1) had the highest percent error, although model estimates were still within $21 \%$ of observed loads. The errors in these three watersheds are both from over- and underestimations. Total phosphorus loads from two of the largest watersheds were underestimated, and the estimate for the next largest watershed was too high. Regardless of the fact that there is no trend in the sign of the error, there is an increase in the crror of the total phosphorus model as the size of the watershed increases, indicating an upper size limit to the applicability of the model.

\subsubsection{Total Nitrogen}

Estimates of total nitrogen loading were not as good as those of the total phosphorus loading. 'The percent difference between estimates and observed loads ranged from 2 to $43 \%$ with an average difference of $23 \%$. Statistically, the percent difference did not differ significantly from zero $\left(t_{a=0.02} d f=11=3.02\right)$. The Wolf Creek load estimate was extremely high compared to the other estimates. The estimated total nitrogen load from Wolf Creek was 1.5 times higher than the observed load. Therefore, the Wolf Creek data were removed from the analysis, and the resulting percent difference was significantly different than zero $\left(t_{a}=0.001, d f=10=5.36\right)$. However, the total nitrogen estimates were accurate to within $15 \%$ of observed values $\left(t_{a}=0.05, d f=10=1.79\right)$.

Model estimations for total nitrogen loads were statistically within $15 \%$ of observed loads. However, in only three watersheds was the percent error actually less than $15 \%$. The model was equally accurate for each physiographic region, indicating that the model may be transportable to other regions. With the exception of the Indian and Wolf Creek watersheds, total nitrogen loads were always underestimated, which suggests a bias in the model.

There were two noticeable trends in model error. First, in all but two watersheds the model estimate of total annual nitrogen load was below the observed load. There are several explanations for this. First, the initial export coefficients were too low, which could be remedied by using higher export coefficients to assign potential loads to land uses. The model could be recalibrated using both the COUNT threshold technique and adjusting the potential load value. Second, the DELIVERY model [Eq. (3.4)] simply may not allow enough transport of total nitrogen to occur. Finally, the model does not account for biological activity such as nitrogen transformation (Hill and Warwick 1987, Langdale et al. 1979). Several records with negative nitrogen-trapping percentages were dropped in developing the total nitrogen models. The total nitrogen delivery model may be underestimating the load as a result. Those negative values meant that total nitrogen load actually increased as water flowed across a surface. These negative values were from 
studies of livestock feedlot waste runoff with a high ammonia content at the input point. Apparently, a lot of nitrogen transformation occurred along the flowpath in these studies, resulting in the increase in total nitrogen. Of these three explanations, we believe the first is the most likely. The hydrologic trend in contributing area suggests that the DELIVERY model is reasonable, and the annual time-step of the model should mitigate errors caused by not modeling nitrogen transformation processes. Calibrating the total nitrogen model by increasing the potential load would cause the model estimation errors to fall into the same range as the phosphorus load estimation errors. This solution is also the easiest to implement.

\subsubsection{Total Suspended Solids}

The total suspended solids model overestimated loads in every watershed. The average difference between the estimated and observed loads was $161 \%$. The model was more accurate in the Isle du Bois River watersheds and particularly in the watersheds within the Cross Timbers region. Except for Buck Creek and Wolf Creek, all the estimates were within $40 \%$ of the observed loads. All but one load estimates for the Elm Fork River watersheds total suspended solids were greater than $150 \%$ over the observed loads. The estimates for total suspended solids load for Buck Creek and TR3 were an order of magnitude too high.

The total suspended solids loading model was the least satisfactory of the three models. Estimates of total suspended solids were most accurate in the Cross Timbers watersheds, and, with the exception of Buck Creek, the model performed better in the entire Isle du Bois system than in the Elm Fork system.

Estimates of total load were consistently high. One explanation for this is that the initial potential loads, calculated from the USLE, were too high. Additionally, some of the studies used to develop the total suspended solids DELIVERY model did have high loads of organic solids, which are transported more readily than sediment particles. Therefore, this delivery model may not be a reasonable model for inorganic solids transport, which is typically the sediment form of concern in mixed-use watersheds.

Another explanation for the model's poor performance could be that the assumption of $100 \%$ stream transport may not be valid in the case of sediment transport. Schumm (1972) states that it takes 100 years for a stream to cleanse itself of all its sediment. While such may be true, the amount of sediment passing a particular point in a stream during the course of a year may equal the amount delivered to the stream from terrestrial sources in an equilibrium between terrestrial delivery of sediment and channel deposition and transport. Deposition and resuspension of sediment in stream channels are well documented (Novotnoy and Chesters 1989). While nutrients that have settled to the bottom may reenter the water column through biologic uptake, sediments must wait for a storm event for resuspension. Thus, sediment exported from a field may deposit in a stream, taking years to reach the outlet of a watershed. To model this type of transport would require differentiation of particles by size, a task which was beyond the scope and intent of this research. Several models address sediment transport by particle sizes 
(CREAMS, ANSWERS, AGNPS), and my model could be recalibrated by assigning the stream cells a delivery value of less than $100 \%$.

The assumption of $100 \%$ stream transport may be valid, however. The perent error would be expected to increase as watershed size increased if the assumption were invalid, which is not the case because two of the largest watersheds have the lowest percent error (IDB1 and IDB2). Alternative methods to calculating potential sediment load, such as the WEPP model (Rawls and Foster 1987), may provide some solutions to the total suspended solids model errors.

\subsection{REGIONAL ANALYSIS OF MODELS}

Estimates of total pollutant loads from each watershed, grouped by physiographic region, are compared to observed loads in Table 3.6.

\subsubsection{Eastern Cross Timbers Physiographic Region}

A COUNT threshold of 15 was used to define the drainage network in Indian Creek and Wolf Creek watersheds. Estimates of total phosphorus and total nitrogen loads were within 1 and $17 \%$, respectively, of the observed loads for the Indian Creek watershed (Table 3.6). The estimate of total suspended solids in Indian Creek was $36 \%$ higher than the observed load, which is about the same magnitude of overestimation as in the Timber Creek watershed.

All three pollutant loads from Wolf Creek were overestimated, but the loads were still within an order of magnitude of observed loads. Because the characteristics of Wolf Creek are similar to Indian and Timber creek watersheds, it is unlikely that the models simply did not work as well in this watershed as in the others. However, the flow data indicate that Wolf Creek is more likely to experience no flow than Indian and Timber creeks, (Appenóix F: e, f, and g). This finding, may indicate some necessary adjustments in the models for use in small intermittent watersheds. A second explanation also lies in the observed data. Measurements in the Wolf Creek watershed did not start until April 8, 1986, and ten sampling dates were missed. Over $50 \%$ of the annual loads to Indian and Timber creeks came during this same period. Assuming that half of the annual load was not measured could account for the differences in the total nitrogen estimates, but that would not account for the total differences in estimated and observed loads of total phosphorus and total suspended solids.

\subsubsection{Blackland Prairic Physiographic Region}

The IDB3 and IDB2 watersheds were modeled using a COUNT threshold value of five because the majority of these watersheds were in the Blackland Prairie region. Both of these watersheds have other watersheds flowing into them, thus complicating the modeling process. Timber Creek watershed flows into the IDB3 watershed, and IDB3 flows into IDB2, which also drains the Buck Creck watershed. To allow comparisons 
between observed and estimated loads, the estimated loads from Timber Creek were added to the estimated loads from IDB3. In turn, the estimated loads from IDB3 and Buck Creek were added to the estimated loads from IDB2.

Estimated loads from IDB3 for total phosphorus, total nitrogen, and total suspended solids were within 9,25, and 19\%, respectively, of observed loads. Estimated loads from the IDB2 watershed for total phosphorus, total nitrogen, and total suspended solids were within 2,25 , and $26 \%$, respectively, of observed loads.

The IDB1 watershed combines flow from IDB2 and the Wolf Creek and Indian Creek watersheds. The portion of this watershed not within the others is within the Cross Timbers region and, therefore, was run using a COUNT threshold of 15 to define the stream network. Loading estimates for total phosphorus, total nitrogen, and total suspended solids were within 21,38 , and $2 \%$, respectively, of observed loads.

\subsubsection{Grand Prairie Physiographic Region}

All the watersheds in the Grand Prairie region were run using a COUNT threshold of eight. The TR4 watershed estimated loads for total phosphorus, total nitrogen, and total suspended solids were within 10,2 , and $167 \%$, respectively, of the observed values. The TR3 estimated loads were within 2, 24, and $15 \%$ of observed loads for total phosphorus, total nitrogen, and total suspended solids, respectively. Estimated loads from the TR2 watershed were within 12 and $43 \%$ of observed values of total phosphorus and total nitrogen, respectively, while the estimated total suspended solids load was 3.6 times higher than the observed load. Results from the TR1 watershed, which combines loads from both Spring Creek and TR2, are similar to the TR2 watershed.

\subsection{LOAD-CONTRIBUTING AREAS ANALYSIS}

\subsubsection{Pollutant Comparisons}

The total load-contributing area for each pollutant from each watershed was determined (Table 3.7). Total area contributing total phosphorus load averaged $46.33 \%$ for the Cross Timbers watersheds (COUNT threshold $=15$ ). The average contributing area increased to $52 \%$ in the Grand Prairie watersheds (COUNT threshold $=8$ ) and increased again to $79 \%$ in the Blackland Prairie watersheds (COUNT threshold $=5$ ). The same pattern was observed for the total suspended solids model.

Contributing areas from the total nitrogen model results do not follow this trend, however (Fig. 3.6). There was an average contributing area of $70.33 \%$ for total nitrogen in the Cross Timbers watersheds. The overall difference in contributing areas did not change much when the threshold was changed from 15 to 8 in the total phosphorus and total nitrogen models. There was a large increase in contributing area from all three pollutant models when the count threshold was reduced to five. 
82

Table 3.7. Percent area of each watershed contributing to total phosphorus, total nitrogen, and total suspended solids load

\begin{tabular}{|c|c|c|c|}
\hline Watershed & $\begin{array}{c}\text { Total phosphorus } \\
(\%) \\
\end{array}$ & $\begin{array}{c}\text { Total nitrogen } \\
(\%) \\
\end{array}$ & $\begin{array}{c}\text { Total suspended solids } \\
(\%) \\
\end{array}$ \\
\hline \multicolumn{4}{|c|}{ Cross Timbers watersheds (COUNT threshold $=15$ ) } \\
\hline Timber Creek & 58 & 79 & 55 \\
\hline Indian Creek & 42 & 67 & 42 \\
\hline Wolf Creek & 39 & 65 & 41 \\
\hline \multicolumn{4}{|c|}{ Grand Prairie watersheds (COUNT threshold $=8$ ) } \\
\hline Spring Creek & 55 & 54 & 50 \\
\hline TR4 & 55 & 37 & 52 \\
\hline TR3 & 49 & 38 & 46 \\
\hline TR2 & 50 & 41 & 46 \\
\hline TRI & 51 & 44 & 48 \\
\hline \multicolumn{4}{|c|}{ Blackland Prairie watersheds (COUNT threshold $=5$ ) } \\
\hline Buck Creek & 75 & 78 & 73 \\
\hline 1DB3 & 73 & 85 & 68 \\
\hline IDB2 & 89 & 85 & 90 \\
\hline
\end{tabular}


A two-way analysis of variance (ANOVA) was performed to determine if there were significant differences between the mean contributing areas for each COUNT threshold and each pollutant being modelled. There were significant differences in contributing area between the watersheds modeled with different COUNT thresholds $\left(F_{p=0.0001}=65.20\right)$. There were also significant differences in the average contributing areas in the watersheds for different pollutant models $\left(F_{p=0.025 s}=4.26\right)$. However, there was a strong interaction between the COUNT threshold and the pollutant being modeled $\left(F_{p}=0.0006=7.08\right)$, which confounds the interpretation of the ANOVA. The strong interaction between the COUNT threshold and the pollutant model means that the effect of the COUNT threshold on the contributing area depends upon which pollutant model was used. Comparing the marginal means of the contributing areas for each group of models and COUNT threshold pairs offers an explanation for the significance of the interaction term (Fig. 3.8). The trend in the mean contributing area is different for the total nitrogen model than for the other two models. Instead of decreasing as the COUNT threshold increased, the contributing area increased dramatically. This trend may be due to the soil permeability in the different physiographic regions and the fact that nitrogen can be transported in subsurface flow as well as overland flow.

\subsubsection{Effect of Stream Network Density}

The drainage density, as set by the COUNT threshold, had a major influence on the contributing area of each pollutant (Fig. 3.9). As the threshold was lowered, more and more area contributed to the pollutant load for a watershed, as expected, because the area within the stream network itself increased.

The other important factor influencing contributing area size and shape was the cell delivery ratio for each pollutant. As FLOPATH calculations progressed upslope within the stream network, there was always $100 \%$ delivery. Once calculations progress outside the streain network, total flow path delivery ratios started to decrease. The rate of decrease depended on the magnitude of the cell delivery ratios. Since the delivery ratio equations were different for each pollutant, the total contributing areas were also different. In general, total contributing areas were smallest for total suspended solids and largest for total nitrogen. This pattern is not surprising. Suspended solids delivery is depended on the load-carrying capacity during overland flow (Fig. 3.10). Any vegetation along a flow path quickly reduces load carrying capacity and reduce the delivery. Because large solid particles are removed from solution first and phosphorus is preferentially adsorbed to the smaller clay particles in sediment, contributing areas for total phosphorus are slightly larger than total suspended solids (Fig. 3.11). Total nitrogen is linked not only to surface flow but also to subsurface flow. 


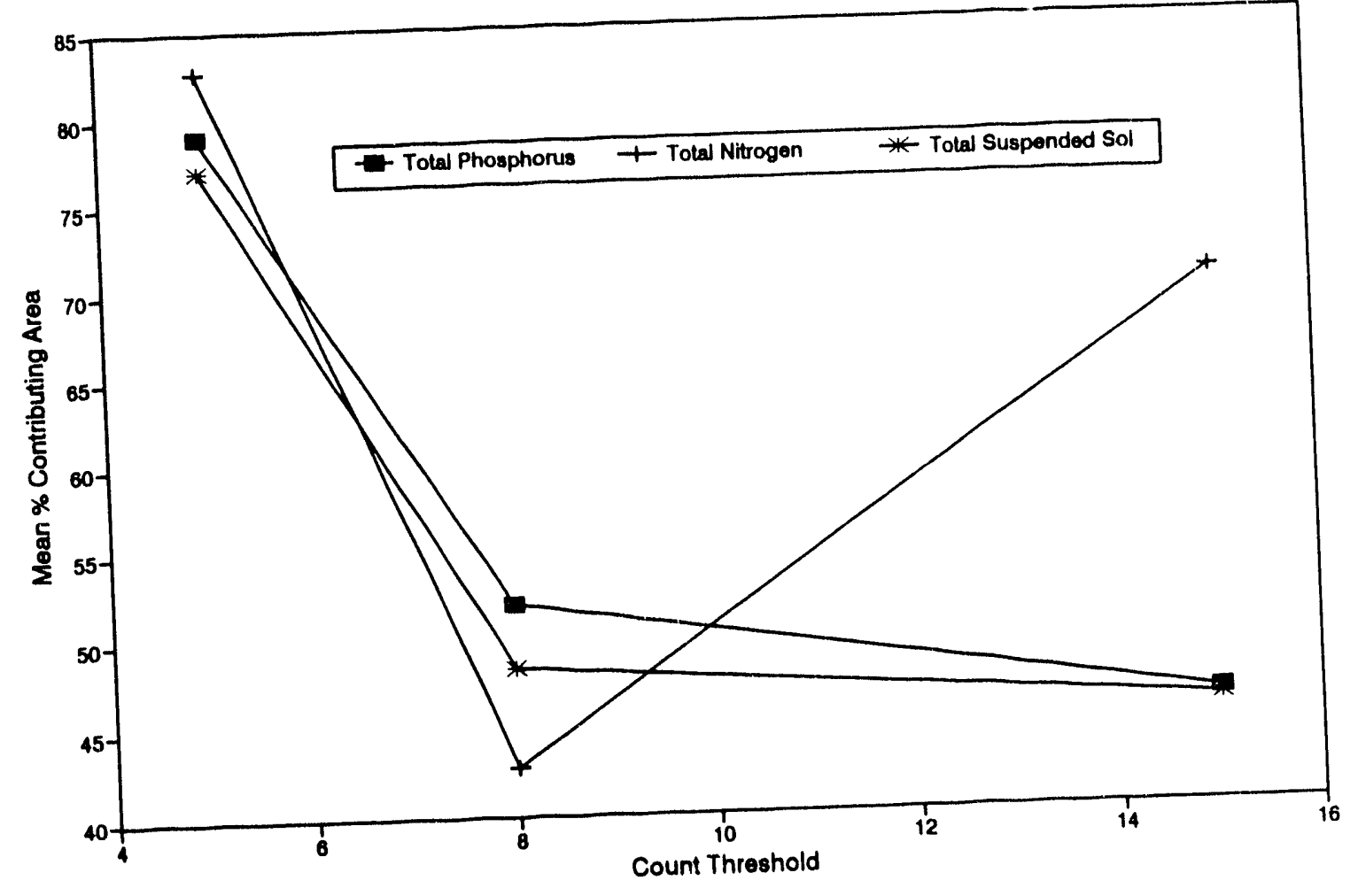

Fig. 3.8. Average contributing area for total phosphorus, total nitrogen, and total suspended solids for watersheds run using three different COUNT thresholds. 

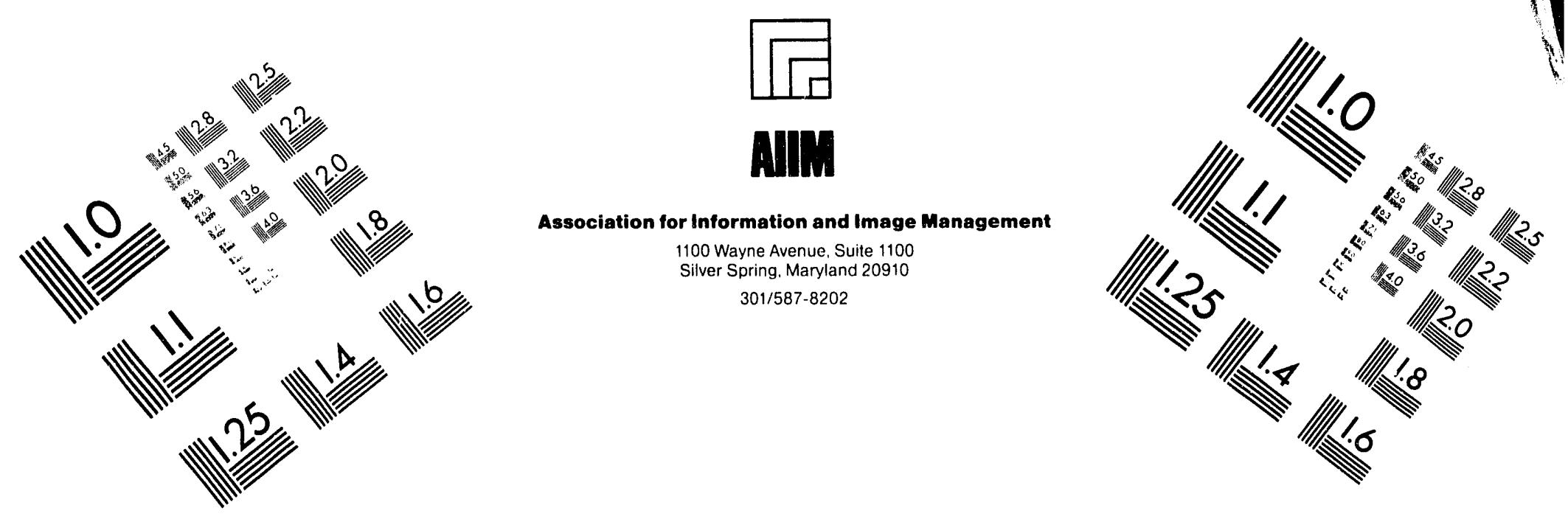

\section{Centimeter}

1
2

Inches
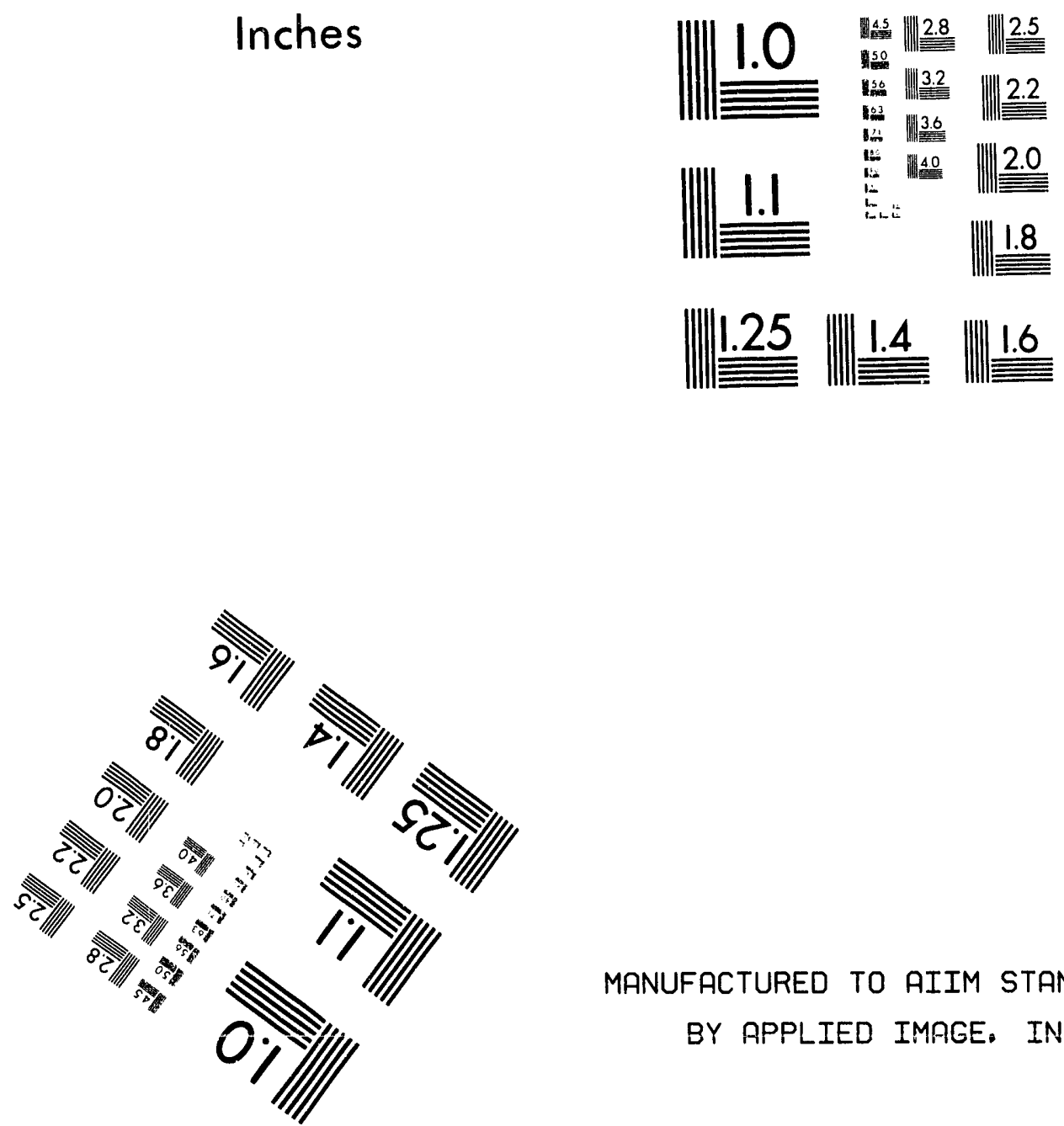

MANUFACTURED TO AIIM STANDARDS

BY APPLIED IMAGE. INC.

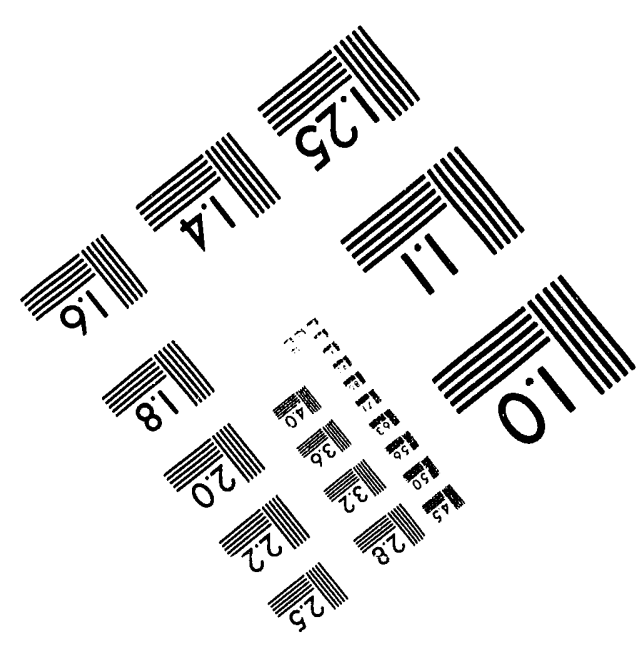



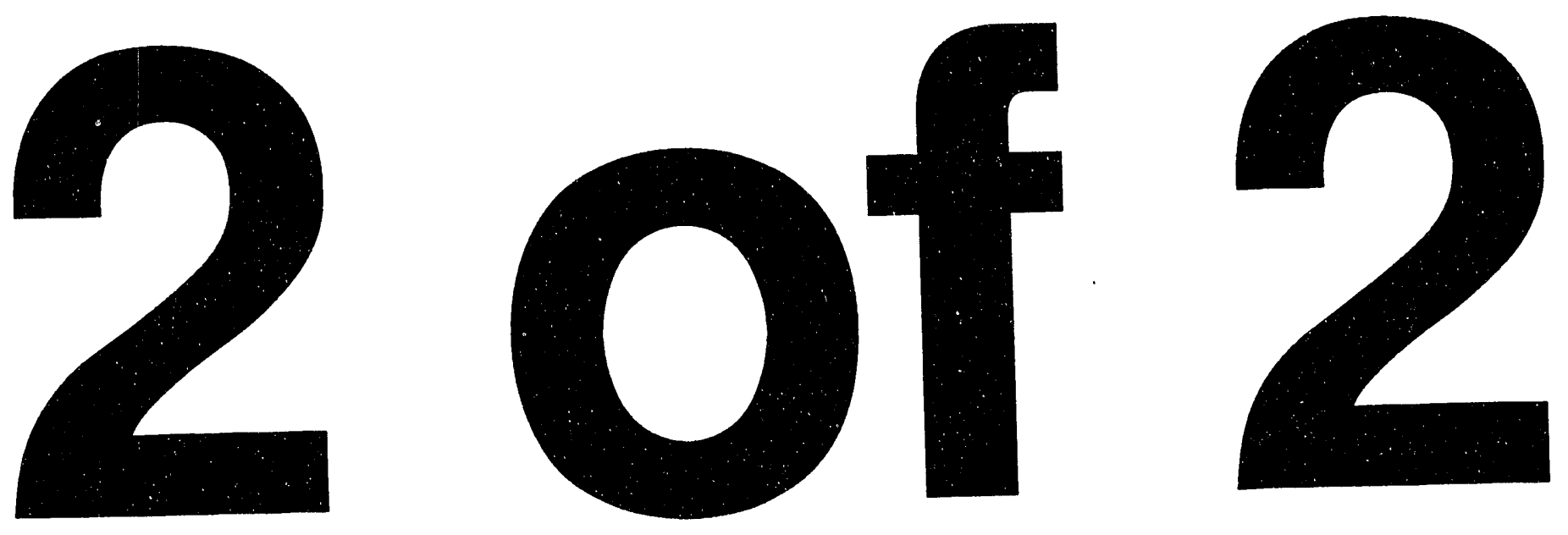


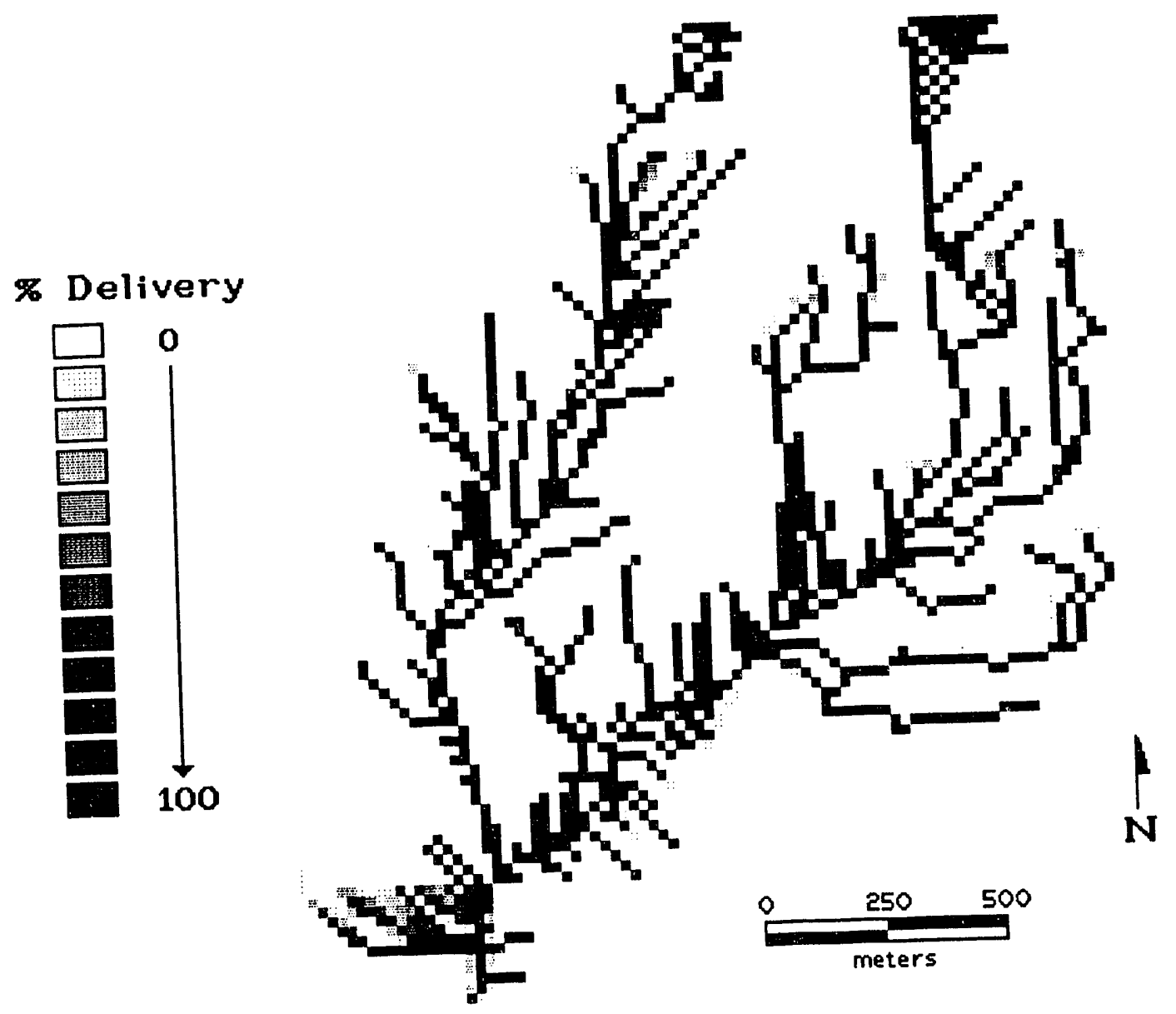

Fig. 3.10. Present delivery of total suspended solids from a small portion of the Buck Creek watershed. 
\% Delivery
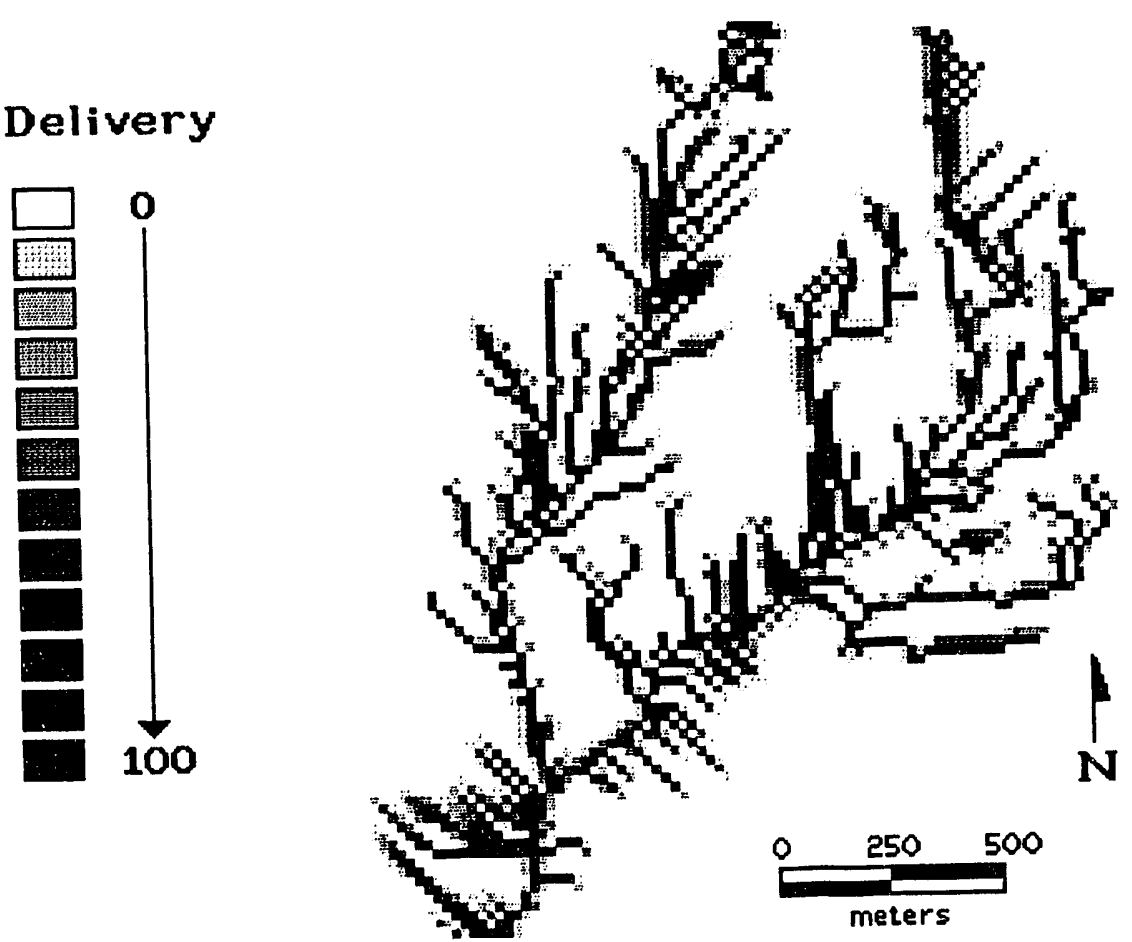

Fig. 3.11. Percent delivery of total phosphorus from a small portion of the Buck Creek Watershed. 
This is because nitrogen species are common in soluble form and are not associated with particulate matter. Because of this, the total area contributing nitrogen load is greater than those for total suspended solids and total phosphorus (Fig. 3.12). The hydrologic basis of the FLOPATH model and the DELIVERY models appear to be describing these processes successfully.

"A knowledge of the areas of a catchment that produce saturation overland flow would allow major non-point source areas of various contaminants to be delineated..." Dunne et al. 1975

Total areas contributing pollutant load followed the pattern expected, with the exception of the total nitrogen model applied to the Cross Timbers watershed. Overall, more area contributed loads in the watersheds dominated by clay soils and less area contributed loads in the watersheds dominated by sandy soils. This is both an expression of the COUNT threshold used in each region and the DELIVERY model. In fact, the DELIVERY model can explain the anomaly in the trend of contributing area for total nitrogen. While the smallest contributing areas were found in the Cross Timbers region for total phosphorus and total suspended solids, the total area contributing to nitrogen load is almost as high in this region as it is in the Blackland Prairie region. Total phosphorus and total suspended solids are almost entirely dependent on overland flow. As discussed previously, the Cross Timbers region is dominated by sandy soils with high permeabilities and low occurrences of overland flow. Additionally, because this region has more forested areas, the likelihood of overland flow is reduced. The DELIVERY models [Eqs. (3.3) and (3.5)] for total phosphorus and total suspended solids, respectively, reflect this. Permeability is a factor in both models, and Manning's roughness coefficient appears in the total phosphorus model.

Total nitrogen delivery, on the other hand, is not linked to sediment particle delivery, nor is it entirely dependent on overland flow. Because nitrogen species are often transported in solution, delivery is not as dependent on surface roughness as are pollutants associated with particulates. Subsurface movement of nitrogen is common and can even dominate the nitrogen pathway (Jacobs and Gilliam 1985; Hill and Warwick 1987). In sandy soils, like those found in the Cross Timbers region, permeability is high, and subsurface flow rate can also be high. Rapid water movement through the soil matrix can prevent or reduce the rate of biological uptake of nitrogen resulting in more nitrogen reaching a stream. Soil texture enters into the total nitrogen DELIVERY model [Eq. (3.4)] as MPD, indicating its importance. The positive sign and the magnitude of the coefficient indicate that soil texture is the most important factor in the delivery of nitrogen, after slope. A large particle diameter suggests higher permeability and more subsurface flow. This would explain the large nitrogen-contributing areas in the Cross Timbers watersheds. 


\section{x Delivery}
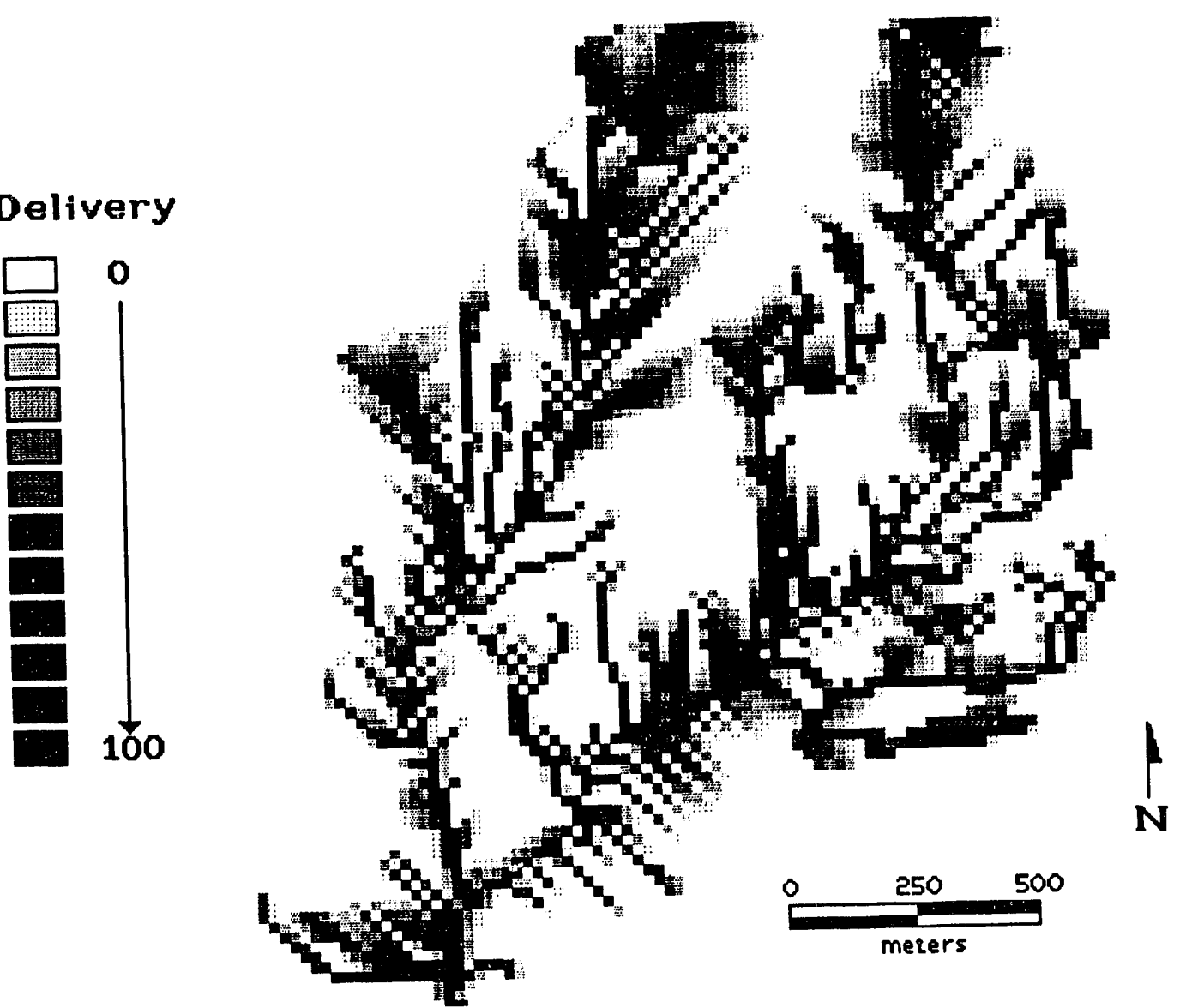

Fig. 3.12. Percent delivery of total nitrogen from a small portion of the Buck Creek watershed. 


\subsection{MODEL EFFICIENCY}

DELIVERY and FLOPATH were run on each watershed for each of the three pollutants. In general, DELIVERY took between 10 and 25 min., depending on the size of the data base. DELIVERY was run on a Dell 386SX PC operating at $20 \mathrm{MHz}$ with a mathematics coprocessor and $8 \mathrm{MB}$ of random access memory (RAM). FLOPATH, run on a VAX 3500 with an operating speed of 15 million instructions per second (MIPS) and $16 \mathrm{MB}$ of memory, took between 2- and 3- min. elapsed time for each watershed. The data transfer between the VAX and the PC was by far the most time-consuming part of the modeling procedure. Efforts are underway to operate FLOPATH on a PC. Having both FLOPATH and COUNT programs in the PC environment would climinate data transfer requirements; eliminate the need for a mainframe computer and; thus, make the model more available to watershed managers.

\subsection{MANAGEMENT IMPLICATIONS}

There are important implications for management from the results of these models. First, the models show that, during an average rainfall year, between 30 and $50 \%$ of the area of a watershed does not contribute significantly to nutrient or sediment loading. The actual area depends upon the characteristics of the watershed, the wetness or dryness of a given water year, and the pollutant of concern. While much of the watershed does not contribute to nutrient and sediment load, the distribution of the areas that do contribute is widespread across the watershed. Additionally, the pollutantcontributing areas do not follow a pattern defined by an equidistant corridor around the baseflow stream network. Many agencies use distance from a stream to delineate buffer zones to protect water resources. The results from this model suggest that the pollutantcontributing area is irregularly shaped; in some cases, areas within $40 \mathrm{~m}$ of the stream are not contributing any pollutant load, while in other instances areas within $200 \mathrm{~m}$ do contribute pollutant load (Figs. $3.10-3.12$ ). This finding may explain why studies by Omernik et al. (1981) and Hunsaker et al. (1991) did not show improvement in correlations between land use for entire watersheds and water quality and land use within equidistance buffers and water quality. Omernik et al. (1981) offered two explanations for this phenomenon. First, they believed that the watersheds used were in an equilibrium state relative to nutrient movement. Second, they suggested that the stream network used to define the equidistant corridors were not dense enough. My model results support this observation. The stream networks used in the Omernik studies were from blue-line on 7.5-min. quadrangles. The stream network densities that proved in our models to be hydrologically relevant to the movement of nutrients and sediments is much higher.

It is also important for managers to be aware of how the critical management areas depend on the pollutant they are managing. Contributing areas are different for each pollutant, as portrayed in Figs. 3.10 - 3.12. These areas are dynamic from storm to storm and from year to year. 


\subsection{CONCLUSIONS}

The overall goal of this project was to develop a set of models that were widely applicable and available to watershed managers. This required that the model be (1) easy to understand, (2) easy to develop the data base for, (3) operational on a PC, and (4) able to make reasonable estimations of annual nutrient and sediment loads for a wide range of watershed sizes and types.

The model is relatively simple to understand. It is based on the ability of a parcel of land to deliver a unit mass of a pollutant. Because the process is modeled with statistical regression equations, knowledge of partial differential equations, common in other hydrologically based models, is unnecessary. Additionally, the model makes use of the widely used export coefficient concept and simply applies flow path delivery ratios to these. This is exactly how the USLE has been used for over 20 years.

The data base necessary to run such models is relatively easy to create. Most agencies responsible for watershed management and that have a GIS system probably already have, or are in the process of developing, the necessary data. The models require mapped land-use, soils, and elevation data. Attribute values related to land use and soils are available in the literature and county soil surveys. Digital elevation data are still not widely available at the resolution necessary for the model. Soils data are also not widely available in digital format; however, like the DEMs, this is changing, and both data layers should be available in the near future. The expense of creating all these data layers can be justified because of the utility of this information for many applications.

The current form of the modeling process requires that both a $\mathrm{PC}$ and a workstation or mainframe computer be available to the user. The COUNT program also needs to be converted to run on a PC in the DOS environment. It is not clear how these conversions will affect model efficiency or if this will limit the size of the array that could be processed by FLOPATH and COUNT. There are other GIS packages with modules that perform tasks similar to those that FLOPATH and COUNT perform [MAP ${ }^{\star}$ (Tomlin 1990) GRASS ${ }^{\otimes}$ (USACERL 1991)]. It is not clear whether these packages do exactly the same thing, however, or if there are limits to the array dimensions of their data sets.

The final and most important goal in developing these models was to make sufficiently accurate estimates to allow management alternatives to be modeled, and to allow an evaluation of these alternatives as well as an evaluation of the effect of a regional perturbation such as climate change on water quality. Additionally, the models should be applicable to a range of wate:shed types and sizes. This was tested by running and evaluating the model on the set of subwatersheds within the Lake Ray Roberts watershed.

Another goal of this modeling effort was to develop that capability to generate delivery ratios that could vary spatially and temporally. The regression equations developed from the literature provide the tool to calculate delivery ratios in a distributed format. Linking the cell delivery ratios to the hydrologic flowpath provides a method of varying the flowpath delivery ratios temporally. Because the actual flowpath delivery ratio 
values in each cell depend on the density of the stream network, the delivery ratios can be varied with time using the hydrologic response to precipitation events.

In Sect. 1 I define six specific hypotheses to test in order to evaluate the utility of the models developed. The following discussion will describe the results of the hypotheses-testing exercises.

The first hypothesis was to evaluate the assumption that when the nutrient export coefficients were used in a distributed fashion, for a large watershed high estimates of actual load would result if no delivery ratio was applied. The results clearly demonstrate that the export coefficients chosen yield load estimates an order of magnitude too high when compared to observed loads. This test may help explain why the export coefficients compiled by Reckhow et al. (1980) are much higher on average than the national average export coefficients developed by Rast and Lee (1983). The compilation of export coefficients are generally from small watersheds or test plots and do not incorporate any loss of mass that might occur outside of these small areas. The national average export coefficients were developed from a set of larger watersheds and do, to some extent, incorporate transmission losses over larger areas and therefore are consistently lower then coefficients from smaller watersheds. The flowpath delivery ratio portion of my models, in essence, is a method of accounting for this discrepancy in a distributed way.

The second hypothesis addresses model accuracy. This was tested by comparing the observed loads from each watershed to the estimated loads. The models were accurate enough to provide both a qualitative and, in some instances, a quantitative planning tool to watershed managers. Annual loads of total phosphorus were estimated to within 5\% of observed annual load in 12 watersheds representing 3 physiographic regions. Annual loads of total nitrogen were estimated to within $15 \%$ of observed loads for the same watersheds. The model can be calibrated to improve total nitrogen load estimates by changing potential loads as well as using the COUNT threshold to define the stream network. While the estimated annual loads for total suspended solids were not as nearly accurate as the total phosphorus and total nitrogen models, they were still within the range of values expected for these watersheds. Development of in-stream delivery ratios or alternative methods of calculating potential sediment load should provide improvement to this model. Overall, the models certainly work well enough to provide a useful planning tool. They should allow evaluation of the relative changes in water quality resulting from changes in annual rainfall amounts and in changes in land-use or landmanagement practices. The total phosphorus and total nitrogen models appear to be able to provide quantitative changes in water quality as well, while the total suspended solids model will require some additional development to provide accurate quantitative estimates.

The third hypothesis was a qualitative test of (1) how important the stream network density was to model output, (2) the utility of stream network density in model calibration, and (3) the utility of the COUNT program to accomplish this. The success in calibrating the models by increasing the stream network density demonstrated the importance of this and the utility of the COUNT program to provide this capability. The fact that the watersheds calibrated along a continuum of soil types that is hydrologically logical further supports the importance of stream network density in model output. However, my assumption that the stream network density should be the same for total 
phosphorus, total nitrogen, and total suspended solids may not have been valid and did influence model success. In these models, I considered a stream cell as having $100 \%$ delivery. It is not necessarily valid to assume that a cell that could transport $100 \%$ of the total nitrogen entering it could also transport $100 \%$ of the total phosphorus. This would be a particularly bad assumption as you approach the "headwater" cell of a stream network. The model success with total phosphorus indicates that the stream network was defined accurately for this pollutant. The fact that total nitrogen load was consistently underestimated suggests that the stream network is probably larger for total nitrogen than total phosphorus. This can be explained simply from the knowledge that much of the total nitrogen is in a soluble form, whereas total phosphorus would be associated with clay particles and would therefore require more energy for transport. Additionally, the total suspended solids loads were always overestimated. Again, it takes more energy to transport solids of all types across a cell then it does to transport clay particles with associated phosphorus. Therefore, the stream network density for total suspended solids would logically be smaller than the total phosphorus stream network. Recalibrating the models separately by pollutant should result in more accurate results.

The fourth hypothesis was a test of how the calibration COUNT values behaved across regions. The COUNT values to which the watersheds within the different physiographic regions calibrated was different and fell along a continuum that would be expected because of the infiltration characteristics of the soils dominating each region. The clay-dominated soils in the Blackland Prairie region required a COUNT value of five to generate a stream. This means that a $2000-\mathrm{m}^{2}$ area is needed to generate stream flow. The Cross Timbers region, dominated by sandy soils, required an area of $6000 \mathrm{~m}^{2}$ (COUNT value of 15) to generate stream flow. The Grand Prairic region, characterized by clay loams and sandy loams, fell in between the other regions with a calibration COUNT value of eight $\left(3200 \mathrm{~m}^{2}\right.$ to generate stream flow). This is further evidence for the utility and validity of using the COUNT threshold technique to calibrate distributed hydrologically based models.

Evaluating the fifth hypothesis required a comparison of contributing areas for each region and each pollutant. Average total areas identified as contributing pollutant loads varied across regions because of the different dominant soil textures, which are related to permeabilities, in each region. The Cross Timbers region, dominated by sandy soils and high permeabilities, had the smallest average contributing areas. The Blackland Prairie region, dominated by clay soils and low permeabilities, had the highest average pollutant contributing areas.

Average total areas identified as contributing pollutant loads also varied within the same region for different pollutants because of different delivery ratio models for each pollutant. Total nitrogen had the largest contributing areas in all watersheds because delivery of total nitrogen is related to subsurface and overland flow. Total phosphorus had the second largest contributing area for all watersheds, and total suspended solids consistently had the smallest contributing areas. I believe that these differences would be even more pronouced had each pollutant model been calibrated sepatately.

Finally, the last hypothesis was designed to evaluate how transportable the models were with respect to watershed size and characteristics. The models are transportable to a 
range of watershed types. The total phosphorus and total nitrogen models work equally well in all three physiographic regions tested in North Texas. The total suspended solids model worked best in the Blackland Prairie and Cross Timbers regions, which are characterized by sandy and clay soils. Annual loadings estimates provided by the total suspended solids model are still good enough to provide a qualitative tool for cvaluation of management alternatives.

The models can be run successfully on watersheds ranging in size from 4400 ha $(10,870$ acres) to almost 100,000 ha $(247,100$ acres $)$, with a slight decrease in model accuracy in the larger watersheds. The efficiency of the models, with respect to computer processing time, is related to watershed size, or more specifically the size of the array which spans the watershed data base. The DELIVERY program took approximately 30 min. to run on the TR4 watershed, which is the largest individual watershed (2065 columns $\times 965$ rows, or almost two million cells) in the data set.

\section{FUTURE RESEARCH}

This research has provided some interesting insights into distributed nonpoint source modeling which can be translated into recommendations for future research. It has provided models of delivery ratios that have a broader application than what has been available in the past. It has provided a technique to allow delivery ratios to be calculated spatially and temporally. It has demonstrated the importance of stream network densities in hydrologically based models and provided tools to make this easier to incorporate into other models. During this research effort several questions arose which were beyond its scope but warrant further attention.

First, while I agree with the philosophy of performing filter-strip research to answer local problems, a standardardized design for this type of research would make the data more useful in a nationwide context. Additionally, the lack of statistical power in many of these types of studies limits their credibility. A more careful study design needs to be imposed on filter-strip-research efforts to make them useful.

Second, I purposely forced the distance factor to remain in my delivery ratio equations to make them useful to managers needing to set filter-strip widths. However, the importance of distance as a predictive variable was sometimes minimal. It would be useful to develop another set of these equations without distance as a explanatory variable. This would accomplish two things: (1) improve the predictive accuracies of the equations and (2) remove the spatial limitations of where the models could be applied. Eliminating distance from these equations would allow the models to be applied at larger resolutions.

Finally, there was no attempt to determine how errors in the regression equations or the GIS data base were propagated during the spatial modeling. Each cell in a GIS data base used for distributed modeling has many errors associated with it. In the case of my modeling effort, there are errors in land use and soil classification and attribute assignments as well as errors associated with the delivery ratios equations. Currently, no technique exists for determining how this error propagates along the flowpaths and across 
the watershed during the modeling process. It would be extremely useful to have a method of determining the total error bounds around model estimates for distributed type models. 


\section{REFERENCES}

Anderson, R. R., E. E. Hardy, J. T. Roach, and R. E. Witmer. 1976. A land use and land cover classification system for use with remote sensor data. Professional Paper 964. U.S. Geological Survey.

Anonymous. 1980. An approach to water resources evaluation of non-point silvicultural sources (WRENS) (A Procedural Handbook). EPA 600)-8-80-012. Forest Service, U.S. Department of Agriculture, Washington D.C.

Bagnold, R. A. 1966. An approach to the sediment transport problem from general physics. Professional Paper 422-J. U.S. Geological Survey.

Band, L. E. 1986. Topographic partition of watersheds with digital elevation models. Water Resour. Res. 22(1):15-24.

Barfield, B. J., E. W. Tollner, and J. C. Hayes. 1979. Filtration of sediment by simulated vegetation. I. Steady-state flow with homogeneous sediment. Trans. ASAE 22(3):540-48.

Barfield, B. J., E. W. Tollner, and J. C. Hayes. 1977. Prediction of sediment transport in a grassed media. American Society of Agriculture Engineers, Paper 77-2023. Presented at the 1977 Annual Meeting of the American Society of Agriculture Enginecrs, Raleigh, NC.

Bartell, S. M. and A. L. Brenkert. 1990. A Spatial-Temporal Model of Nitrogen Dynamics in a Deciduous Forest Watershed. In M. G. Tuner and R. H. Gardner (eds.), Quantitative Methods in Landscape Ecology: The Analysis and Interpretation of Landscape Heterogeneity. Springer-Verlag, New York.

Baun, K. 1985. Modeling sediment delivery from fields to channels: A case for field scale data and hierarchial data structures. In Proceedings of the Nonpoint Pollution Abatement Symposium. Marquette University, Milwaukee, 1985.

Beasley, D. B., L. F. Huggins, and E. J. Monke. 1980. ANSWERS: A model for watershed planning. Trans. ASAE 23(4):938-44.

Beasley, D. B. and L. F. Huggins. 1982. ANSWERS-User's Manual. Department of Agricultural Engineering, Purdue University, West Lafayette, Ind.

Bedient, .P. G., D. A. Harned, and W. G. Characklis. 1978. Stormwater analysis and prediction in Houston. J. Environ. Eng. Div. (ASCE) 104:1087-1100.

Belsley, D. A., E. Kuh, and R. E. Welsch. 1980. Regression Diagnostics. Wiley, New York.

Bennett, J. P. 1974. Concepts of mathematical modeling of sediment yield. Water Resour. Res. 10(3):485-92. 
Berry, J. K. and J. K. Sailor. 1987. Use of a geographic information system for storm runoff prediction from small urban watersheds. Environ. Manage. 11(1):21-27.

Betson, R. P. 1978. Bulk precipitation and streamflow quality relationships in an urban area. Water Resour. Res. 14(6):1165-69.

Betson, R. P. and J. B. Marius. 1969. Source area of storm runoff. Water Resour. Res. 5:574-82.

Beven, K. J. and M. J. Kirkby. 1979. A physically based, variable contributing area model of basin hydrology. Hydrol. Sci. Bull. 24(1):43-69.

Beven, K. and E. F. Wood. 1983. Catchment geomorphology and the dynamics of runoff contributing areas. J. Hydrol. 65:139-58.

Beven, K. J., E. F. Wood, and M. Sivapalan. 1988. On hydrological heterogeneitycatchment morphology and catchment response. J. Hydrol. 100:353-75.

Bingham, S. C., P. W. Westerman, and M. R. Overcash. 1980. Effect of grass buffer zone length in reducing the pollution from land application areas. Trans. ASAE 23:330-35,342.

Brady, N. C. 1974. The Nature and Properties of Soils, 8th ed. Macmillan, New York.

Budd, W. W., P. L. Cohen, P. R. Saunders, and F. R. Steiner. 1987. Stream corridor management in the Pacific Northwest. Environ. Manage. 11:587-605.

Clesceri, N. L., S. J. Curran, and R. I. Sedlak. 1986. Nutrient loads to Wisconsin lakes. Pt. I. Nitrogen and phosphorus export coefficients. Water Resour. Bull. 22(6):983-90.

Cogger, C. and J. M. Duxbury. 1984. Factors affecting phosphorus losses from cultivated organic soils. J. Environ. Qual. 13(1):111-14.

De Roo, A. P. J., L. Hazelhoff, and P. A. Burrough. 1989. Soil erosion modelling using 'ANSWERS' and geographic information systems. Earth Surf. Processes Landforms 14:517-32.

DelRegno, K. J. and S. F. Atkinson. 1988. Nonpoint pollution and watershed management: Remote sensing and geographic information system (GIS) approach. Lake Reservoir Manage. 4(2):17-25.

Dickenson, W. T. and G. Wall. 1977. The relationship between source-area erosion and sediment yield. Hydrol. Sci. Bull. 22:527-30.

Dickenson, W. T. and G. Wall. 1978. Temporal and spatial patterns in erosion and fluvial processes. In Research in Fluvial Systems, R. Davidson-Arnott and W. Nickling (eds.). Geobooks, Norwich, Conn. 
Dickerhoff-Delwiche, L. L. and D. A. Haith. 1983. Loading functions for predicting nutrient losses from complex watersheds. Water Resour. Bull. 19(6):951-59.

Dickey, E. C. and D. H. Vanderholm. 1981. Vegetative filter treatment of livestock feedlot runoff. J. Environ. Qual. 10(3):279-84.

Dillaha, T. A., R. B. Reneau, S. Mostaqhimi, and D. Lee. 1989. Vegetative filter strips for agricultural nonpoint source pollution control. Trans. ASAE 32(2):513-19.

Dillaha, T. A., J. H. Sherrard, D. Lee, S. Mostaghimi, and V. O. Shanholtz. 1988. Evaluation of vegetative filter strips as a best management practice for feed lots. J. Water Pollut. Control Fed. 60(7):1231-38.

Draper, N. and H. Smith. 1981. Applied Regression Analysis. 2d ed. Wiley, New York.

Donigian, A. D., Jr., D. C. Beyerlein, H. H. Davis, Jr., and N. H. Crawford. 1977. Agricultural runoff management (ARM) model-version II: Refinement and testing. EPA 600/3-77-098. U.S. Environmental Protection Agency, Athens, Ga.

Doyle, R. C., D. C. Wolf, and D. F. Bezdicek. 1977. Effectiveness of grass buffer strips in improving the water quality of manure polluted runoff. ASAE Paper 77-2501. St. Joseph, Mich.

Dunne, T. and L. B. Leopold. 1978. Water in Environmental Planning. W. H. Freeman, New York.

Dunne, T., T. R. Moore, and C. H. Taylor. 1975. Recognition of runoff-producing zones in humid regions. Hydrol. Sci. Bull. 20(3):305-27.

Eastman, J. R. 1990. IDRISI: A Grid-based Geographic Analysis System. Graduate School of Geography, Clark University, Worcester, Mass.

Edwards, W. M., L. B. Owens, and R. K. White. 1983. Managing runoff from a small, paved beef feedlot. J. Environ. Qual. 12(2):281-86.

Engel, B. A., R. Srinivasan, and C. C. Rewerts. 1991. A GIS toolbox approach to hydrologic modeling. Proceedings of the 1991 GRASS User's Conference, Berkeley, Calif.

Engman, E. T. 1986. Roughness cocfficients for routing surface runoff. J. Irrig. Drain. Eng. 112(1):39-53.

Engman, E. T. and A. S. Rogowski. 1974. A partial area model for storm flow synthesis. Water Resour. Res. 10(3):464-72.

ESRI (Environmental Systems Research Institute). 1987. ARC/INFO Users Guide. ESRI, Redlands, Calif. 
Frickle, D. G., L. M. Shown, and P. C. Patton. 1975. An evaluation of hillslope and channel erosion related to oil-shale development in the Piceance Basin, northwestern Colorado. Colorado Water Resource Circular 30. Department of Natural Resources, Denver.

Foster, G. R. and L. D. Meyer. 1972. Transport of soil particles by shallow flow. Trans. ASAE 15:92-102.

Gilliland, M. W. and W. Baxter-Potter. 1987. A geographic information system to predict non-point source pollution potential. Water Resour. Bull. 23(2):281-91.

Haber, W. and J. Schaller. 1988. Ecosystem research Berchtesgaden-Spatial relations among landscape elements quantified by ecological balance methods. Presented at the 1988 ESRI European User Conference.

Haith, D. A. and L. L. Shoemaker. 1987. Generalized watershed loading functions for stream flow nutrients. Water Resour. Bull. 23(3):471-78.

Hayes, J. C. and J. E. Hairston. 1983. Modeling the long-term effectiveness of vegetative filters as on-site sediment controls. Trans. ASAE Paper 83-2081. Presented at the 1983 Summer American Society of Agriculture Engineers Meeting, Bozeman, Mont. 1983.

Heerdegen, R. G. and M. A. Beran. 1982. Quantifying source areas through land surface curvature and shape. J. Hydrol. 57:359-73.

Hession, W. C. and V. O. Shanholtz. 1988. A geographic information system for targeting nonpoint source agricultural pollution. J. Soil Water Conser. 43(3):264-66.

Hewlett, J. D. 1961. Soil moisture as a source of base flow from steep mountain watersheds. Station Paper 123. U.S. Department of Agriculture. Southeastern Forest Experiment Station, Asheville, N.C.

Hewlett, J. D. and A. R. Hibbert. 1967. Factors affecting the response of small watersheds to precipitation in humid areas. pp. 275-290. IN W. E. Sopper and H. W. Lull (eds.), Forest Hydrology. Proceedings of a National Science Foundation Advanced Science Seminar at Pennsylvania State University, 1965. Pergamon Press, New York.

Hewlett, J. D. and C. A. Troendle. 1975. Non-point and diffused water sources: A variable source area problem. In Watershed Management. American Society of Civil Engineers, Logan, Utah.

Hibbert, A. R. and C. A. Troendle. 1988. Streamflow generation by variable source area. pp. 111-128. IN W. T. Swank, and D. A. Crossley, Jr. (eds.), Forest Hydrology and Ecology at Coweeta. Ecological Studies Series, Vol. 66. Springer-Verlag, New York.

Hill, A. R. and J. Warwick. 1987. Ammonium transformations in springwater within the riparian zone of a small woodland stream. Can. J. Fish. Aquat. Sci. 44:1948-56. 
Horton, R. E. 1937. Hydrologic interrelations of water and soils. Soil Sci. Soc. Am. Proc. 1:401-29.

Hunsaker, C. T., D. A. Levine, S. P. Timmins, B. L. Jackson, and R. V. O'Neill. 1992. Landscape characterization for assessing regional water quality. pp. 997-1006. IN D. McKenzie, E. Hyatt and J. McDonald. Proceedings of International Symposium on Ecological Indicators, Ft. Lauderdale, Florida, 16-19 October 1990. Elsevier, N.Y.

Hutchinson, M. F. 1989. A new procedure for gridding elevation and stream line data with automatic removal of spurious pits. J. Hydrol. 106:211-32.

Jacobs, T. C. and J. W. Gilliam. 1985. Riparian losses of nitrate from agricultural drainage waters. J. Environ. Qual. 14(4):472-78.

Jensen, S. K. and J. O. Dominque. 1988. Extracting topographic structure from digital elevation data for geographic information system analysis. Photogrammetric Eng. Remote Sensing 54(11):1593-1600.

Johnson, D. W., D. W. Cole, H. Van Miegroet, and F. W. Horing. 1986. Factors affecting anion movement and retention in four forest soils. Soil Sci. Soc. Am. J. 50(3):776-83.

Jones, W. W. and D. A. Levine. 1989. Evaluation of the water quality of three lakes in Shakamak State Park, Indiana: A management plan. Final report to the Indiana Department of Natural Resources. Prepared by the Environmental Systems Application Center, School of Public and Environmental Affairs, Indiana University, Bloomington, Ind.

Karr, J. R. and I. J. Schlosser. 1977. Impact of nearstream vegetation and stream morphology on water quality and stream biota. EPA-600/3-77-97. U.S. EPA (Environmental Protection Agency) Environmental Research Laboratory, Athens, Ga.

Karr, J. R. and I. J. Schlosser. 1978. Water resources and the land-water interface. Science 201:229-33.

Kling, G. F. 1974. A computer model of diffuse sources of sediment and phosphorus moving into a lake. Ph.D. dissertation. Cornell University, Ithaca, N.Y.

Knisel, W. G. (ed.). 1980. CREAMS: A Field-scale model for chemicals, runoff and erosion from agricultural management systems. Conservation Research Report 20. U.S. Department of Agriculture, Washington, D.C.

LaBaugh, J. W. and T. C. Winter. 1984. The impact of uncertainties in hydrologic measurement on phosphorus budgets and empirical models for two Colorado reservoirs. Limnol. Oceanogr. 29(2):322-39. 
Lake, J. 1977. Environmental impact of land use on water quality. Final Report on the Black Creek Project. EPA-905/9-77-007-B. U.S. Environmental Protection Agency, Chicago.

Landon, R. J. 1977. Characterization of urban stormwater runoff in the Tri-County Region. 208 Water Quality Management Plan. Michigan Tri-County Regional Planning Commission, 136.

Langdale, G. W., R. A. Leonard, W. G. Fleming, and W. A. Jackson. 1979. Nitrogen and chloride movement in small upland Piedmont watersheds: II. Nitrogen and chloride transport in runoff. J. Environ. Qual. 8(1):57-63.

Lee, M. 1987. Verifications and applications of a nonpoint source pollution model. IN A. O. Feldman (eds.), Engineering Hydrology. American Society of Civil Engineers. American Society of Civil Engineers, New York.

Leopold, L. B., M. G. Wolman, and J. P. Miller. 1964. Fluvial Processes in Geomorphology. W. H. Freeman, San Francisco.

Levine, D. A. and W. W. Jones. 1990. Modeling phosphorus loading to three Indiana reservoirs: A geographic information system approach. Lake Reservoir Manage. 6(1):81-91.

Li, R. M. 1974. Mathematical modeling of response from small watershed. Ph.D. dissertation. Department of Civil Engineering, Colorado State University, Fort Collins.

Lowrance, R. R., R. Leonard, and J. Sheridan. 1985. Managing riparian ecosystems to control nonpoint pollution. J. Soil Water Conser. 40(1):87-91.

Lowrance, R. R., S. McIntyre, and C. Lance. 1988. Erosion and deposition in a field/forest system estimated using cesium-137 activity. J. Soil Water Conser. 43:195-99.

Lowrance, R. R., R. L. Todd, and L. E. Asmussen. 1983. Waterborne nutrient budgets for the riparian zone of an agricultural watershed. Agric. Ecosyst. Environ. 10:371-84.

Lowrance, R. R., R. L. Todd, and L. E. Asmussen. 1984a. Nutrient cycling in an agricultural watershed: I. Phreatic Movement. J. Environmental Qual. 13(1):22-27.

Lowrance, R. R., R. L. Todd, J. Fail Jr., O. Hendrickson Jr., R. Leonard, and L. E. Asmussen. 1984b. Riparian forests as nutrient filters in agricultural watersheds. Bioscience 34(6):374-77.

Magette, W. L., R. B. Brinsfield, R. E. Palmer, and J. D. Wood. 1987. Nutrient and sediment removal by vegetated filter strips. Trans. ASAE 32:(2):663-67.

Maner, S. B. 1958. Factors influencing sediment delivery rates in the Red Hills physiographic area. Trans. Am. Geophys. Union 39:669-75. 
Mann, C. 1990. Meta-analysis in the breech. Science 249:476-80.

McCaig, M. 1983. Contributions to storm quickflow in a small headwater catchment-The role of natural pipes and soil macropores. Earth Surf. Processes Landforms 8:239-52.

McCullough, M. W. 1985. Urban Runoff Impacts and Management Strategies. North Carolina Division of Coastal Management, Raleigh.

McElroy, A. D., S. Y. Chiu, J. W. Nebgen, A. Aleti, and F.W. Bennett. 1976. Loading functions for assessment of water pollution from nonpoint sources. EPA-600/2-76-151. U.S. Environmental Protection Agency, Office of Research and Development, Washington, D.C.

McGuinness, J. L., L. L Harrold, and W. M. Edwards. 1971. Relation of rainfall energy and streamflow to sediment yield from small and large watersheds. J. Soil Water Conser. 26:233-35.

McLeod, R. V. and R. O. Hegg. 1984. Pasture runoff quality from application of inorganic and organic nitrogen sources. J. Environ. Qual. 13(1):122-26.

Menzel, R. G., E. D. Rhoades, A. E. Olness, S. J. Smith. 1978. Variability of annual nutrient and sediment discharges in runoff from Oklahoma cropland and rangeland. J. Environ. Qual. 7(3):401-06.

Meyer, L. D. and W. H. Wischmeier. 1969. Mathematical simulation of the process of soil erosion by water. Trans. ASAE 12(6):754-62.

Miller, M. H. 1979. Contribution of nitrogen and phosphorus to subsurface drainage water from intensively cropped mineral and organic soils in Ontario. J. Environ. Qual. $8(1): 42-48$.

Mills, D. 1985. Water quality assessment: A screening procedure for toxic and conventional pollutants in surface and ground Water: I. Environmental Research Laboratory Office Research Development, U.S. Environmental Protection Agency, Athens, Ga.

Moore, I. D., E. M. O'Loughlin, and G. J. Burch. 1988. A contour-based topographic model for hydrological and ecological applications. Earth Surf. Processes Landforms 13:30520.

Niebling, W. H. and E. E. Alberts. 1979. Composition and yield of soil particles transported through sod strips. ASAE Paper 79-2065.

Novotny, V. and G. Chesters. 1981. Handbook of Nonpoint Pollution: Sources and Management. Van Nos Reinhold, Atlanta.

Novotnoy, V. and G. Chesters. 1989. Delivery of sediment and pollutants from nonpoint sources: A water quality perspective. J. Soil Water Conser. 44(6):568-76. 
Novotny, V., D. Balsinger, R. Bannerman, J. G. Konrad, D. S. Cherkauer, G. V. Simsiman, and G. Chesters. 1979. Simulation of pollutant loadings and runoff quality. EPA-905/4-79-029E. U.S. Environmental Protection Agency, Great Lakes National Program Office, Chicago.

O'Loughlin, E. M. 1986. Prediction of surface saturation zones in natural catchments by topographic analysis. Water Resour. Res. 22(5):794-804.

Omernik, J. M., A. R. Abernathy, and L. M. Male. 1981. Stream nutrient levels and proximity of agricultural and forest land to streams: Some relationships. J. Soil Water Conser. 36(4):227-31.

Omernik, J. M. 1977. Nonpoint source-stream nutrient level relationships: A nationwide study. EPA-600/3-77-105. U.S. Environmental Protection Agency, Corvallis, Oregon.

Osborne, L. L. and M. J. Wiley. 1988. Empirical relationships between land use/cover and stream water quality in an agricultural watershed. J. Environ. Manage. 26:9-27.

Overcash, M. R., S. C. Bingham, and P. W. Westerman. 1981. Predicting runoff pollutant reduction in buffer zones adjacent to land treatment sites. Trans. ASAE 24(2):430-35.

Overcash, M. R., F. J. Humenick, P. W. Wesserman, and J. W. Gilliam. 1976. Overland flow pretreatment of poultry manure. American Society of Agricultural Engineers Paper 76-4517, St. Joseph, Mich.

Peterjohn, W. T. and D. L. Correll. 1984. Nutrient dynamics in an agricultural watershed: Observations on the role of a riparian forest. Ecology 65(5):1466-75.

Phillips, J. D. 1989a. Nonpoint source pollution control effectiveness of riparian forests along a coastal plain river. J. Hydrol. 110:221-37.

Phillips, J. D. 1989b. An evaluation of the factors determining the effectiveness of water quality buffer zones. J. Hydrol. 107:133-45.

Piest, R. F., L. A. Kramer, and H. G. Heinemann. 1975. Sediment movement from loessial watersheds. IN Present and Prospective Technology for Predicting Sediment Yields and Sources. Publ. ARS-S-40:130-141. U.S. Department of Agriculture, Washington, D.C.

Pillard, D. A. 1988. Pre-impoundment estimations of nutrient loading to Ray Roberts Lake and prediction of post-inundation trophic status. Ph.D. dissertation. University of North Texas, Denton, Texas.

Rast, W. and G. F. Lee. 1983. Nutrient loading estimates for lakes. J. Environ. Eng. 109(2):502-16.

Rawls, W. J. and G. R. Foster. 1987. USDA-water erosion prediction project (WEPP). pp. 702-707. IN Eng. Hydrol. American Soceity of Civil Engineers. New York. 
Reckhow, K. H., J. P. Hartigan, and S. Coffey. 1989. Lake nutrient budget development for state-level applications. IN Proceedings of National Conference on Enhancing States' Lake Management Programs, 1988, Chicago. North American Lake Management Society.

Reckhow, K. H. 1979. Empirical lake models for phosphorus: Development, applications, limitations, and uncertainty. pp. 193-222, IN D. Scavia, and A. Robertson (eds.), Perspectives on Lake Ecosystem Modeling. Ann Arbor Science Publishers, Ann Arbor, Mich.

Reckhow, K. H., M. N. Beaulac, and J. T. Simpson. 1980. Modeling phosphorus loading and lake response under uncertainty: A manual and compilation of export coefficients. EPA 440/5-80-011. U.S. Environmental Protection Agency, Washington, D.C.

Regan, R. M. and J. D. Fellows. 1980. An overview of remote sensing based information systems for hydrologic modeling. IN Proceedings of the 14th International Symposium on Remote Sensing of the Environment, Vol. 1, April 23-30, 1980, San Jose, Costa Rica. Environmental Research Institute of Michigan, Ann Arbor.

Roman, C. T. and R. E. Good. 1983. Wetlands of the New Jersey pinelands: Values, functions, impacts, and a proposed buffer delineation model. Center Coastal Environmental Studies, Rutgers University, New Brunswick, N.J.

SAS Institute, Inc. 1985. SAS User's Guide: Statistics. SAS Institute, Inc., Cary, N.C.

Schlosser, I. J. and J. R. Karr. 1981a. Water quality in agricultural watersheds: Impact of riparian vegetation during baseflow. Water Resour. Bull. 17(2):233-40.

Schlosser, I. J. and J. R. Karr. 1981b. Riparian vegetation and channel morphology impact on spatial patterns of water quality in agricultural watersheds. Environ. Manage. $5(3): 233-43$.

Schumm, S. A. 1972. Fluvial geomorphology. IN Dowden, Hutchinson, and Ross (eds.), River Morphology. Dowden Publishing Co., Stroudsburg, Pa.

Schwab, G. O., R. K. Frevert, T. W. Edminster, and K. K. Barnes. 1981. Soil and Water Conservation Engineering. 3rd ed. John Wiley, New York.

Schwer, C. B. and J. C. Claussen. 1989. Vegetative filter treatment of dairy milkhouse wastewater. J. Environ. Qual. 18:446-51.

Shanholtz, V. O., E. R. Yagow, J. M. Flagg, R. K. Byler, S. Mostaghimi, and T. A. Dillaha. 1988. Agricultural pollution potential database for Culpeper Soil and Water Conservation District. Interim Report VirGIS 88-2. Department of Conservation and Historic Resources, Division of Soil and Water Conservation, Richmond, Va.

Sharpley, A. N., S. J. Smith, and J. R. Williams. 1988. Nonpoint source pollution impacts of agricultural land use. Lake and reservoir manage. 4(1):41-49. 
Skaggs, R. S. and R. Khaleel. 1982. Infiltration. IN C. T. Hann (ed.), Hydrologic Modeling of Small Watersheds. American Society of Agricultural Engineers.

Thompson, D. B., T. L. Loudon, and J. B. Gerrish. 1979. Animal manure movement in winter runoff for different surface conditions. pp. 145-158. IN R. C. Loehr, D. A. Heith, M. F. Walter, and C. S. Martin (eds.), Best Management Practices for Agriculture and Silviculture. Proceedings of the 1978 Cornell Agricultural Waste Management Conference. Ann Arbor, Mich.

Tichendorf, W. G. 1969. Tracing storm flow to varying source areas in a small forested watershed in the southeastern Piedmont. Ph.D. dissertation. University of Georgia, Athens.

Tomlin, C. D. 1990. Geographic Information Systems and Cartographic Modeling. Prentice Hall, Englewood Cliffs, N.J.

Troendle, C. A. 1979. A variable source area model for storm flow prediction on first-order forested watersheds. Ph.D. dissertation. University of Georgia, Athens.

Troendle, C. A. 1985. Variable source area models. pp. 347-407. IN Anderson, M. G., and T. P. Burt (eds.), Hydrological Forecasting. Wiley, New York.

United States Army Corps of Engineers. 1991. GRASS User's Manual. U.S. Army Corps of Engineers Research Laboratory, Champaign, Ill.

USDA (United States Department of Agriculture). 1972. National Engineering Handbook, Sect. 4: Hydrology. Soil Conservation Service, Washington, D.C.

USDA (United States Department of Agriculture). 1978. Soil Survey of Montague County, Texas. Soil Conservation Service, Washington, D.C.

USDA (United States Department of Agriculture). 1979. Soil Survey of Cooke County, Texas. Soil Conservation Service, Washington, D.C.

USDA (United States Department of Agriculture). 1980a. Soil Survey of Grayson County, Texas. Soil Conservation Service, Washington, D.C.

USDA (United States Department of Agriculture). 1980b. Soil Survey of Denton County, Texas. Soil Conservation Service, Washington, D.C.

U.S. EPA (United States Environmental Protection Agency). 1988. Summary report: The literature review of ecological benefits of the Conservation Reserve Program. Office of Policy, Planning and Evaluation, Washington, D.C.

U.S. SCS (United States Soil Conservation Service). 1975. Procedure for computing sheet and rill erosion on project areas. Technical Release 51, Washington, D.C. 
Vanderholm, D. H., E. C. Dickey, J. A. Jacobs, R. W. Elmore, and S. L. Spahr. 1979. Livestock feedlot runoff control by vegetative filters. EPA-600/2-79-143. U.S. Environmental Protection Agency. U.S. Government Printing Office, Washington, D.C.

Vollenweider, R. R. 1975. Input-output models with special reference to the phosphorus loading concept in limnology. Scheizerische Zeitscripft de Idrobiologia 33:53-83.

Walling, D. E. 1983. The sediment delivery problem. J. Hydrol. 65:209-37.

Warwick, J. and A. R. Hill. 1988. Nitrate depletion in the riparian zone of a small woodland stream. Hydrobiologia 157:231-40.

Whitmore, R. C. and G. G. Ice. 1984. A review of models for estimating the effect of forestry management practices on yield and transport of materials to receiving waters. Technical Bulletin 420. NCASI (National Council of the Paper Industry for Air and Stream Improvement), New York.

Williams, J. R. 1977. Sediment delivery ratios determined with sediment and runoff models. Publ. 122. International Association Hydrolology Science.

Williams, J. R. and H. D. Berndt. 1972. Sediment yield computed with a universal equation. J. Hydrol. Div. Proc. ASCE 98(HY2):2087-98.

Williams, R. D. and E. D. Lavey. 1986. Selected buffer strip references. Internal report prepared by the Water Quality and Watershed Research Laboratory (USDA-ARS), Durant, Okla.

Willrich, T. L. and J. O. Boda. 1976. Overland flow treatment of swine lagoon effluent. ASAE Paper 76-4515. St. Joseph, Mich. American Society of Agricultural Engineers.

Winkler, R. D. and R. L. Rothwell. 1983. Biogeoclimatic classification system for hydrologic interpretations. Cana. J. For. Res. 13:1043-50.

Wischmeier, W. H. 1976. Use and misuse of the universal soil loss equation. J. Soil Water Conser. 31(1):5-9.

Wischmeier, W. H. and D. D. Smith. 1978. Predicting Rainfall Erosion Loss-A Guide to Conservation Planning. Agriculture Handbook 537. U.S. Department of Agriculture (USDA), Washington, D.C.

Yang, C. T. 1972. Unit stream power and sediment transport. J. Hydraul. Div. ASCE 98(HY10):1805-27.

Young, R. A., T. Huntrods, and W. Anderson. 1980. Effectiveness of vegetated buffer strips in controlling pollution from feedlot runoff. J. Environ. Qual. 9(3):483-87. 
Young, R. A., C. A. Onstad, D. D. Bosch, and W. P. Anderson. 1989a. AGNPS: A nonpoint-source pollution model for evaluating agricultural watersheds. J. Soil Water Conser. 44(2):168-73.

Young, R. A., C. A. Onstad, D. D. Bosch, and W. P. Anderson. 1989b. AGNPS, agricultural nonpoint source pollution model: A large watershed analysis tool. Cons. Res. Rpt. 35. USDA-Agriculture Research Service, Washington, D.C. 
APPENDIX A

Soils Data for the Lake Ray Roberts Watershed. 
Table A.1. Soils found in the Lake Ray Roberts watershed

\begin{tabular}{|c|c|c|c|}
\hline Soil name and textural class & $\begin{array}{l}\text { Permeability } \\
\text { (in./h) }\end{array}$ & $\begin{array}{l}\text { Mean } \\
\text { particle } \\
\text { diameter } \\
(\mathrm{mm})\end{array}$ & $\begin{array}{l}\text { Erosion } \\
\text { K-factor }\end{array}$ \\
\hline Aledo loam & 0.60 & 0.1130 & 0.32 \\
\hline Aledo gravelly clay loam & 0.60 & 0.1130 & 0.32 \\
\hline Aledo loam & 0.60 & 0.1130 & 0.32 \\
\hline Altoga clay loam & 0.60 & 0.1030 & 0.32 \\
\hline Altoga silty clay & 0.60 & 0.0236 & 0.32 \\
\hline Arenosa fine sand & 20.00 & 0.2800 & 0.17 \\
\hline Arents loam & 2.00 & 0.1240 & 0.32 \\
\hline Aubrey fine sandy loam & 2.00 & 0.1630 & 0.32 \\
\hline Aubrey-Birome-Urban land complex & 0.60 & 0.1630 & 0.32 \\
\hline Aubrey loam & 2.00 & 0.1240 & 0.32 \\
\hline Austin silty clay & 0.20 & 0.0236 & 0.32 \\
\hline Bastrop fine sandy loam & 2.00 & 0.1630 & 0.24 \\
\hline Birome fine sandy loam & 0.60 & 0.1630 & 0.37 \\
\hline Birome-Aubrey-Rayex complex & 2.00 & 0.1630 & 0.32 \\
\hline Birome-Rayex-Aubrey complex & 0.60 & 0.1630 & 0.34 \\
\hline Bolar clay loam & 0.60 & 0.1030 & 0.32 \\
\hline Bolar stony clay loam & 0.60 & 0.1130 & 0.32 \\
\hline Bolar-Aledo complex & 0.60 & 0.1030 & 0.32 \\
\hline Bolar-Maloterre-Aledo complex & 0.20 & 0.1030 & 0.15 \\
\hline Bosque loam & 0.60 & 0.1240 & 0.28 \\
\hline Bosque loam & 0.60 & 0.1240 & 0.28 \\
\hline Branyon clay & 0.06 & 0.0785 & 0.32 \\
\hline Branyon silty clay & 0.06 & 0.0236 & 0.32 \\
\hline Bunyan and Whitesboro soils & 2.00 & 0.1750 & 0.43 \\
\hline Bunyan fine sandy loam & 2.00 & 0.1630 & 0.43 \\
\hline Burleson clay & 0.06 & 0.0785 & 0.32 \\
\hline Callisburg fine sandy loam & 0.60 & 0.1630 & 0.37 \\
\hline Callisburg sandy loam & 0.60 & 0.1240 & 0.32 \\
\hline Crockett fine sandy loam & 0.60 & 0.1630 & 0.43 \\
\hline Crockett loam & 0.60 & 0.1240 & 0.43 \\
\hline Crosstell-Urban land complex & 0.60 & 0.1630 & 0.43 \\
\hline Duffau fine sandy loam & 2.00 & 0.1630 & 0.32 \\
\hline Elbon clay & 0.20 & 0.0785 & 0.32 \\
\hline Fairlie-Urban land complex & 0.06 & 0.0785 & 0.32 \\
\hline Fairlie and Houston Black clays & 0.06 & 0.0325 & 0.32 \\
\hline Ferris-Heiden clays & 0.06 & 0.0785 & 0.32 \\
\hline Frio clay loam & 0.20 & 0.1030 & 0.32 \\
\hline Frio silty clay & 0.20 & 0.0236 & 0.32 \\
\hline Frio clay & 0.20 & 0.1030 & 0.32 \\
\hline Gaddy loam & 2.00 & 0.1500 & 0.17 \\
\hline Gaddy sand & 6.00 & 0.1500 & 0.17 \\
\hline
\end{tabular}




\begin{tabular}{|c|c|c|c|}
\hline Soil name and textural class & $\begin{array}{l}\text { Permeability } \\
\text { (in./h) }\end{array}$ & $\begin{array}{l}\text { Mean } \\
\text { particle } \\
\text { diameter } \\
(\mathrm{mm})\end{array}$ & $\begin{array}{l}\text { Erosion } \\
\text { K-factor }\end{array}$ \\
\hline Gasil fine sandy loam & 2.00 & 0.1630 & 0.24 \\
\hline Gasil-Urban land complex & 6.00 & 0.1630 & 0.20 \\
\hline Gasil loam & 6.00 & 0.2500 & 0.20 \\
\hline Gladewater clay & 0.06 & 0.0785 & 0.32 \\
\hline Gowen fine sandy loam & 0.60 & 0.1630 & 0.28 \\
\hline Gowen clay loam & 0.60 & 0.1030 & 0.28 \\
\hline Gowen loam & 0.60 & 0.1240 & 0.28 \\
\hline Gowen loam & 0.60 & 0.1030 & 0.28 \\
\hline Heaton loamy fine sand & 2.00 & 0.2200 & 0.17 \\
\hline Heiden clay & 0.06 & 0.0785 & 0.32 \\
\hline Hensley loam & 0.20 & 0.1240 & 0.37 \\
\hline Justin fine sandy loam & 0.60 & 0.1630 & 0.28 \\
\hline Kaufman clay & 0.05 & 0.0785 & 0.32 \\
\hline Konsil loamy fine sand & 6.00 & 0.2200 & 0.20 \\
\hline Konsil fine sandy loam & 2.00 & 0.1630 & 0.24 \\
\hline Lewisville clay loam & 0.60 & 0.1030 & 0.32 \\
\hline Lindale-Urban land complex & 0.20 & 0.1030 & 0.32 \\
\hline Lindy clay loam & 0.60 & 0.1030 & 0.37 \\
\hline Lindy loam & 0.60 & 0.1240 & 0.37 \\
\hline Mabank fine sandy loam & 0.60 & 0.1630 & 0.43 \\
\hline Mabank loam & 0.60 & 0.1240 & 0.43 \\
\hline Maloterre-Aledo complex & 0.20 & 0.1150 & 0.23 \\
\hline Medlin-Sanger stony clays & 0.06 & 0.0785 & 0.32 \\
\hline Miller clay & 0.06 & 0.0785 & 0.32 \\
\hline Minco very fine sandy loam & 0.60 & 0.1500 & 0.28 \\
\hline Mingo clay loam & 0.60 & 0.1030 & 0.37 \\
\hline Navo clay loam & 0.06 & 0.1030 & 0.32 \\
\hline Normangee-Urban land complex & 0.06 & 0.1030 & 0.32 \\
\hline Normangee loam & 0.06 & 0.1030 & 0.32 \\
\hline Ovan clay & 0.06 & 0.0785 & 0.32 \\
\hline Ponder loam & 0.20 & 0.1240 & 0.43 \\
\hline Pulexas loam & 2.00 & 0.1500 & 0.28 \\
\hline Purves clay loam & 0.20 & 0.1030 & 0.32 \\
\hline Renfrow loam & 0.60 & 0.1240 & 0.37 \\
\hline San Saba-Slidell complex & 0.06 & 0.0785 & 0.32 \\
\hline Sanger clay & 0.06 & 0.0785 & 0.32 \\
\hline Sanger silty clay & 0.06 & 0.0236 & 0.32 \\
\hline Sanger stony clay & 0.06 & 0.0785 & 0.28 \\
\hline Silawa loamy fine sand & 6.00 & 0.2200 & 0.17 \\
\hline Silstid loamy fine sand & 6.00 & 0.2200 & 0.17 \\
\hline Slidell clay & 0.06 & 0.0785 & 0.32 \\
\hline Slidell-San Saba complex & 0.06 & 0.0785 & 0.32 \\
\hline
\end{tabular}




\begin{tabular}{lccc}
\hline & & Mean & \\
Soil name and textural class & $\begin{array}{c}\text { Permeability } \\
\text { (in./h) }\end{array}$ & $\begin{array}{c}\text { particle } \\
\text { diameter } \\
\text { (mm) }\end{array}$ & $\begin{array}{c}\text { Erosion } \\
\text { K-factor }\end{array}$ \\
\hline Somervell gravelly loam & & & \\
Speck Variant loam & 0.60 & 0.1360 & 0.32 \\
Speck clay loam & 0.20 & 0.1240 & 0.32 \\
Stephen silty clay & 0.20 & 0.1030 & 0.32 \\
Teller fine sandy loam & 0.20 & 0.0236 & 0.32 \\
Tinn clay & 2.00 & 0.1030 & 0.28 \\
Tinn clay & 0.06 & 0.0785 & 0.32 \\
Trinity clay & 0.06 & 0.0785 & 0.32 \\
Truce-Owens complex & 0.06 & 0.0785 & 0.32 \\
Ustolls-Rock outcrop association & 0.60 & 0.1630 & 0.24 \\
Venus loam & 0.00 & 0.0000 & 0.00 \\
Vertel-Urban land complex & 0.60 & 0.1240 & 0.28 \\
Wauriki-Renfrow complex & 0.06 & 0.0785 & 0.37 \\
Whitesboro loam & 0.60 & 0.0726 & 0.43 \\
Whitewright-Eddy-Howe complex & 0.60 & 0.1240 & 0.28 \\
Wilson clay loam & 0.60 & 0.0362 & 0.32 \\
Wilson silty clay loam & 0.20 & 0.1030 & 0.43 \\
Windthorst loamy fine sand & 0.20 & 0.0362 & 0.43 \\
Windthorst fine sandy loam & 2.00 & 0.2200 & 0.24 \\
Zilaboy clay & 0.60 & 0.1630 & 0.49 \\
\hline & 0.06 & 0.0785 & 0.32 \\
\hline
\end{tabular}

'Data were obtained from county soil surveys for Cooke, Denton, Grayson, and Montague Counties, Texas (USDA, 1978, 1979, 1980a, 1980b). 


\section{APPENDIX B}

Data Base Used for Developing Delivery Ratio Models. 


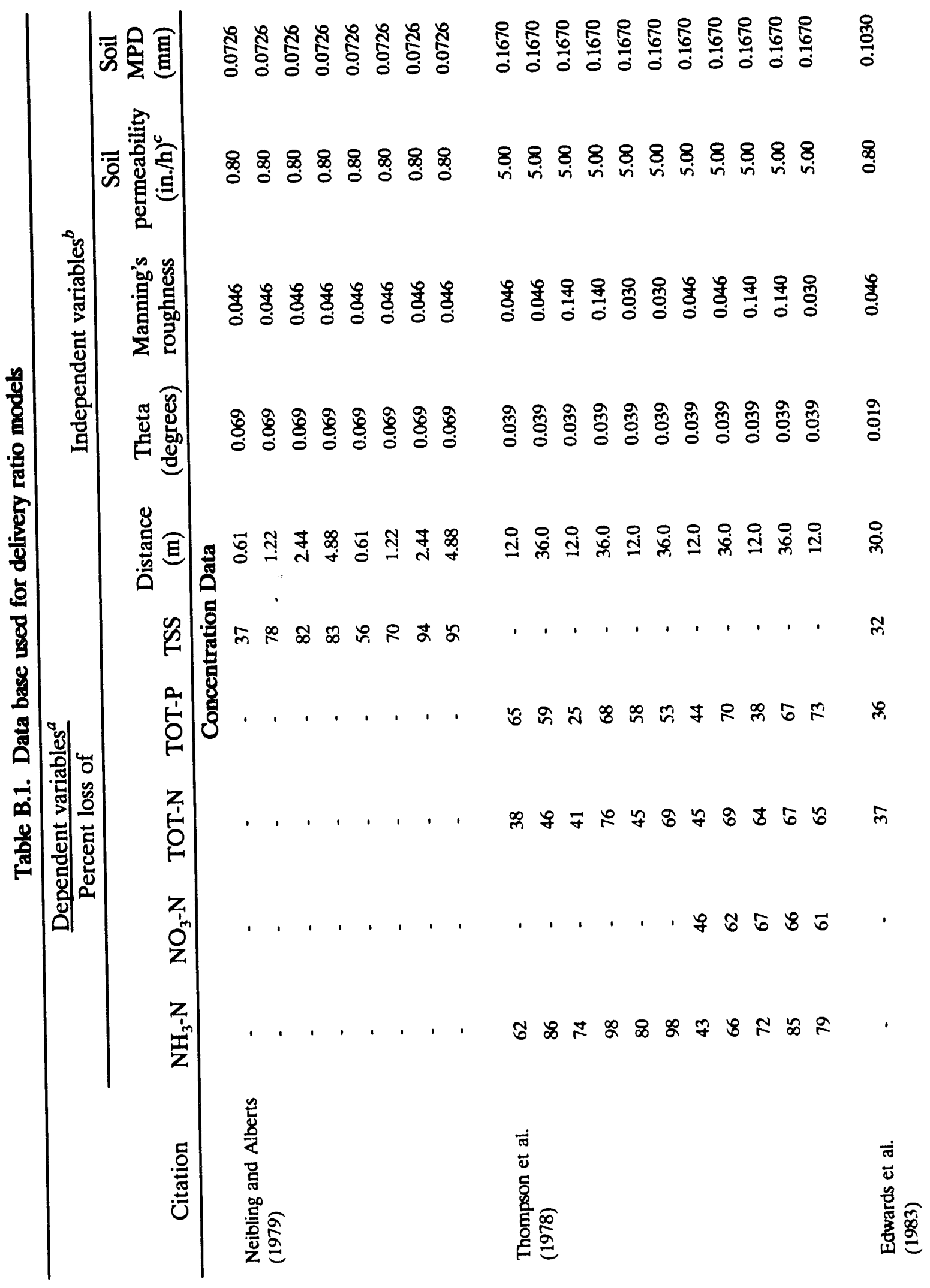




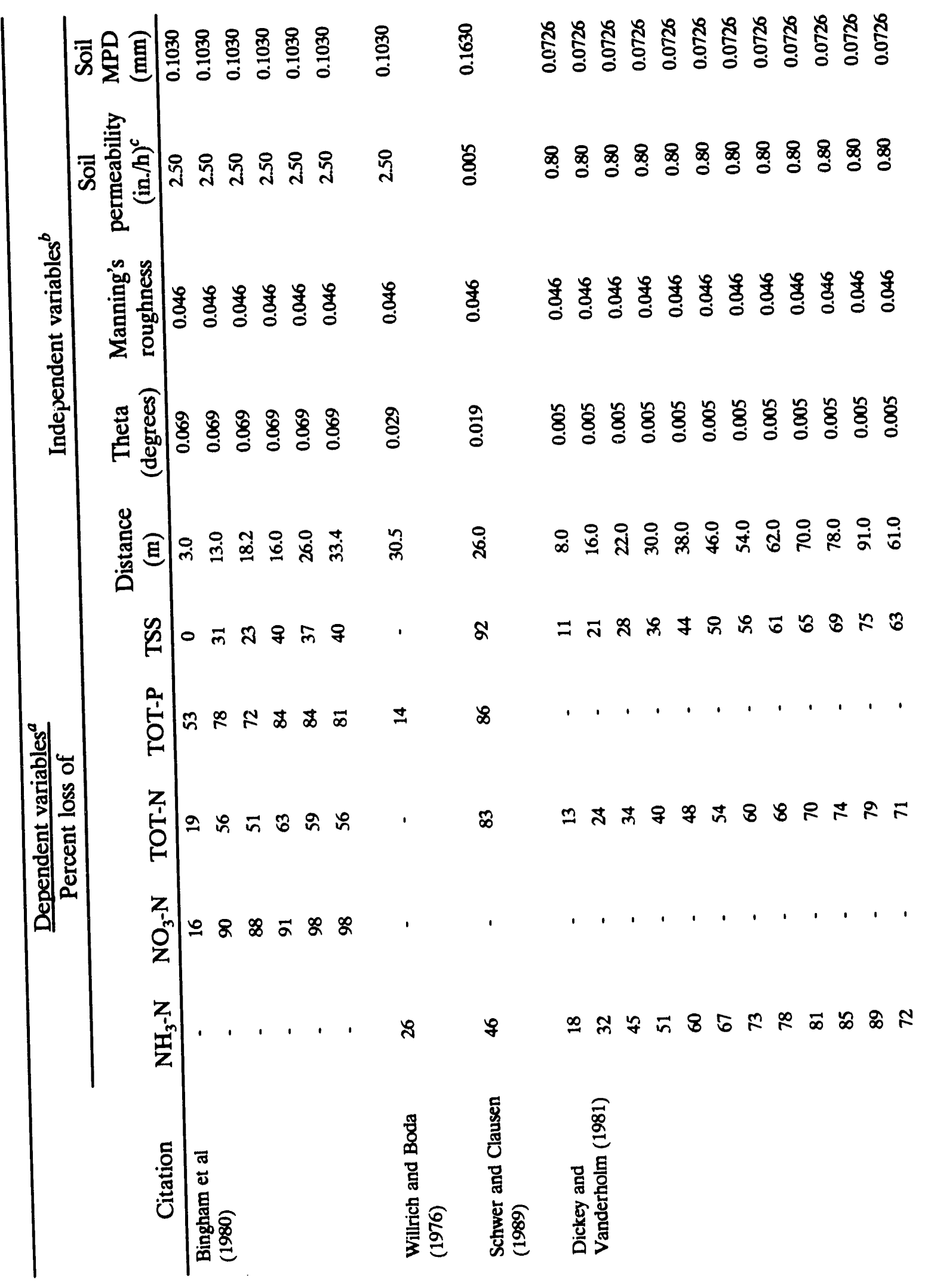




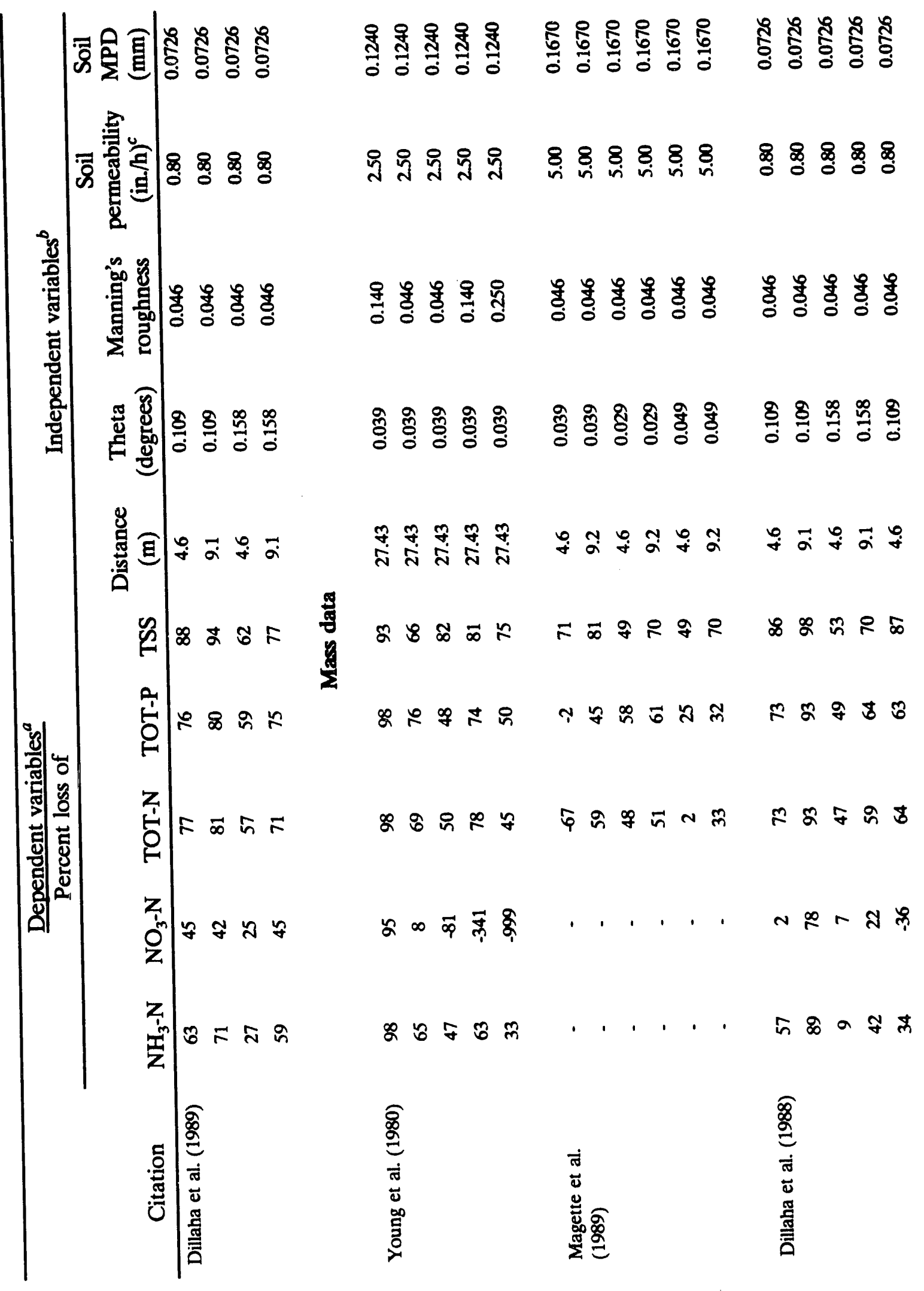




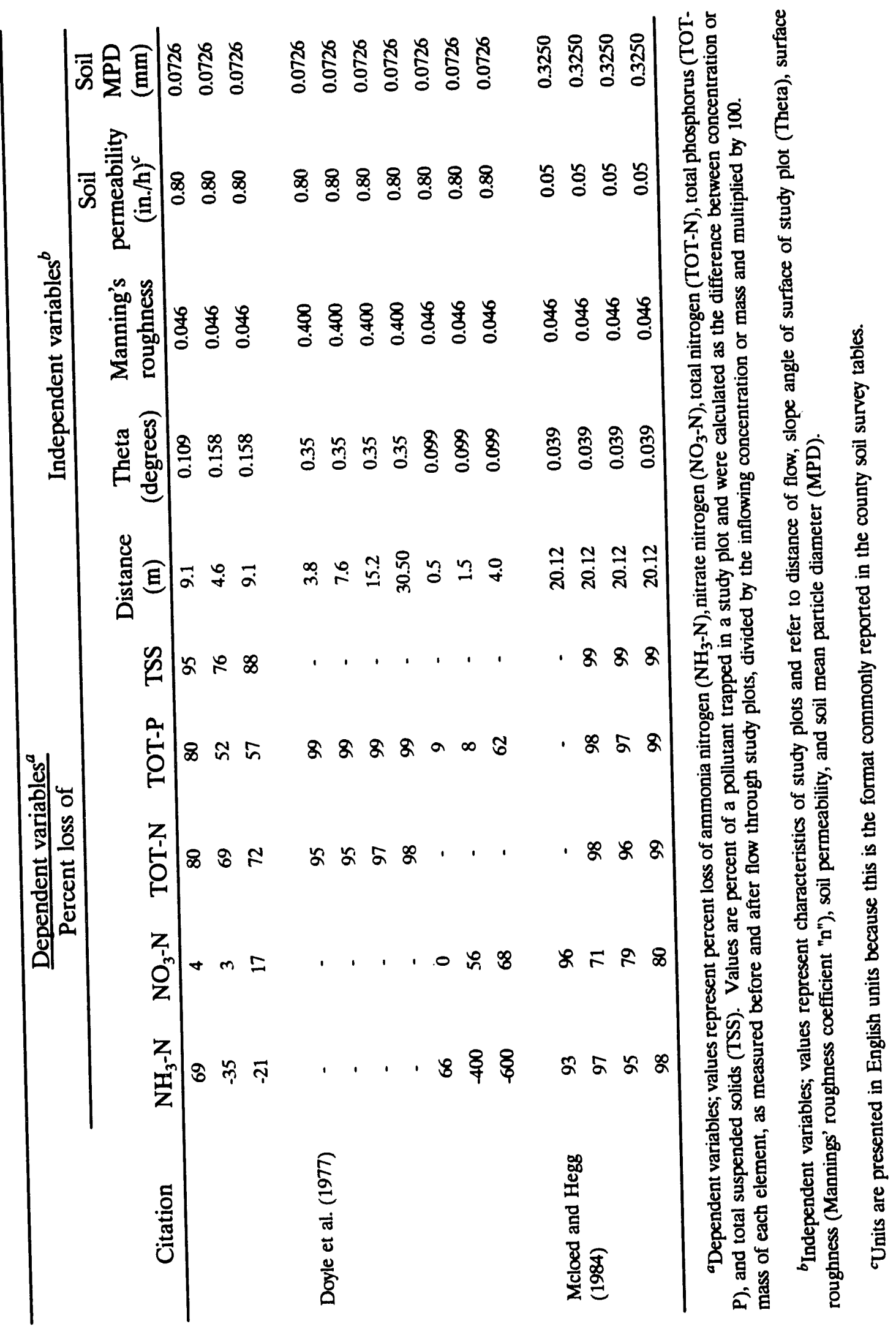




\section{APPENDIX C}

USLE: a Turbo Pascal program that reads an IDRISI image file with input variables for the Universal Soil Loss Equation (USLE) and produces potential sediment yield for each cell. 
PROGRAM usle; \{Programmer: Daniel A. Levine\}

\{This program takes an image with soil landuse slope\}

\{and distance codes and calculates potential\} \{sediment load from each cell using the Universal soil loss\} \{equation\}

\section{Uses Crt;}

VAR

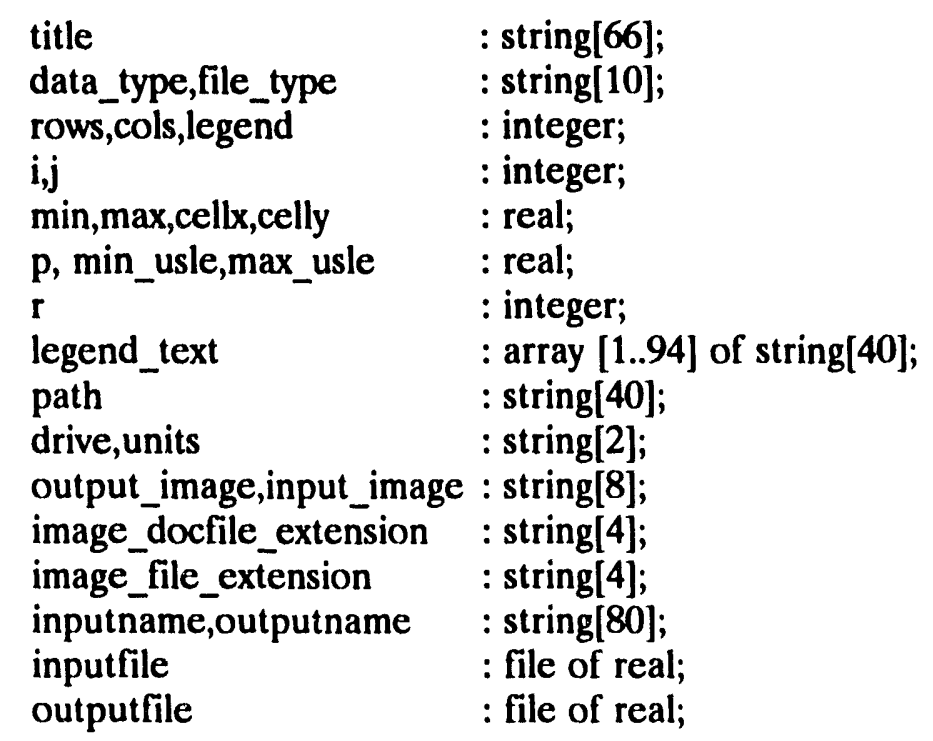

PROCEDURE Create_output_Docfile;

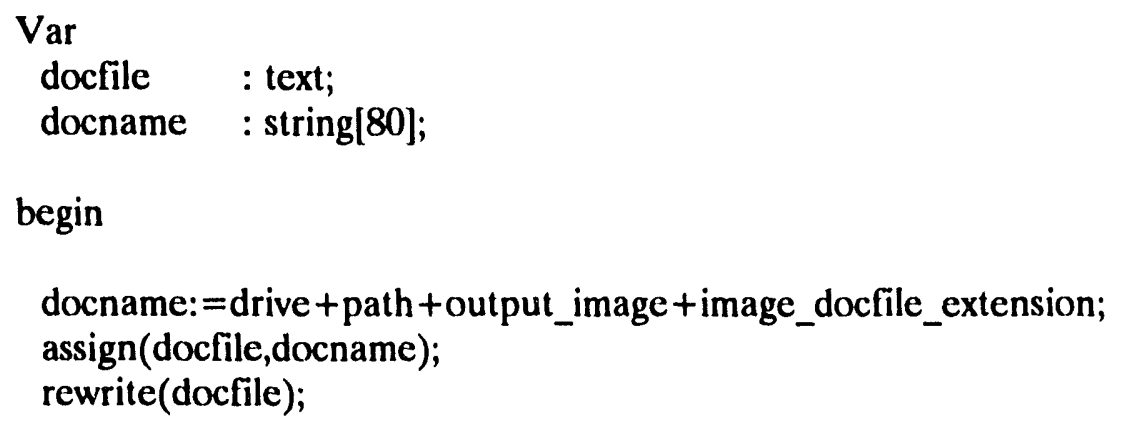

docname:=drive + path + output_image + image_docfile_extension; assign(docfile,docname); rewrite(docfile);

writeln(docfile,'image title: ',title);

writeln(docfile,'data_type: real');

writeln(docfile,'file_type: binary');

writeln(docfile,'rows: ',rows);

writeln(docfile,'columns: ',cols); 
writeln(docfile,'minimum: ',min_usle);

writeln(docfile,'maximum: ',max_usle);

writeln(docfile,'cell x: ',cellx);

writeln(docfile,'cell y: ',celly);

writeln(docfile,'legend: ',0);

close(docfile);

END; $\{$ Procedure Create_Celltime_Docfile\}

$\{$ \{

PROCEDURE USLELOAD;

\{this procedure calculates sediment yield based on info read\} \{in main program\}

$\begin{array}{ll}\text { Var } & \text { : real; } \\ \text { rtemp } & \text { : longint; } \\ \text { itemp } & \text { : real; } \\ \text { usleyield } & : \text { real; } \\ \text { s,c,k,x,l,distance,slope } & : \text { integer; } \\ \text { code, soil, lu } & : \text { string[5]; } \\ \text { Istring } & : \text { string[1]; } \\ \text { soilstr,landstr } & : \text { string[3]; } \\ \text { slopestr } & \end{array}$

Begin

For $j:=1$ to rows do

For $i:=1$ to cols do

Begin

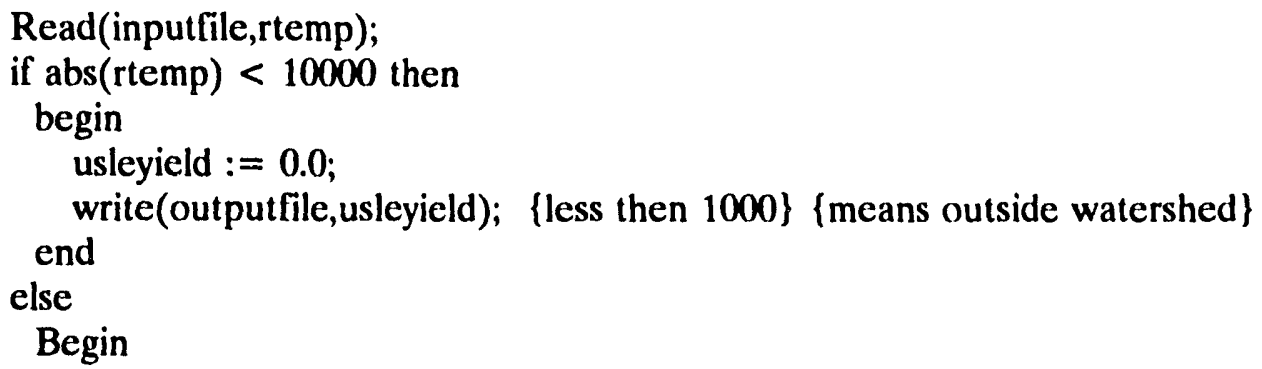

\{take input itemp value, parse value into values for soil\} \{land and slope $\}$ 


$$
\begin{aligned}
& \text { itemp := Round(rtemp); } \\
& \text { Str(abs(itemp),istring); } \\
& \text { soilstr } \quad:=\text { Copy(istring,1,1); delete(istring,1,1); } \\
& \text { landstr } \quad:=\text { Copy(istring,1,1); delete(istring,1,1); } \\
& \text { slopestr } \quad:=\text { Copy(istring,1,3); }
\end{aligned}
$$

Val(soilstr, soil,code);

Val(landstr, lu,code);

Val(slopestr,slope,code);

\{determine distance of slope in cell convert distance\}

if itemp $<0$ then distance $:=20.0$ else distance $:=20^{*} \operatorname{sqrt}(2)$;

\{convert soil code to erosion $\mathrm{k}$ factor\}

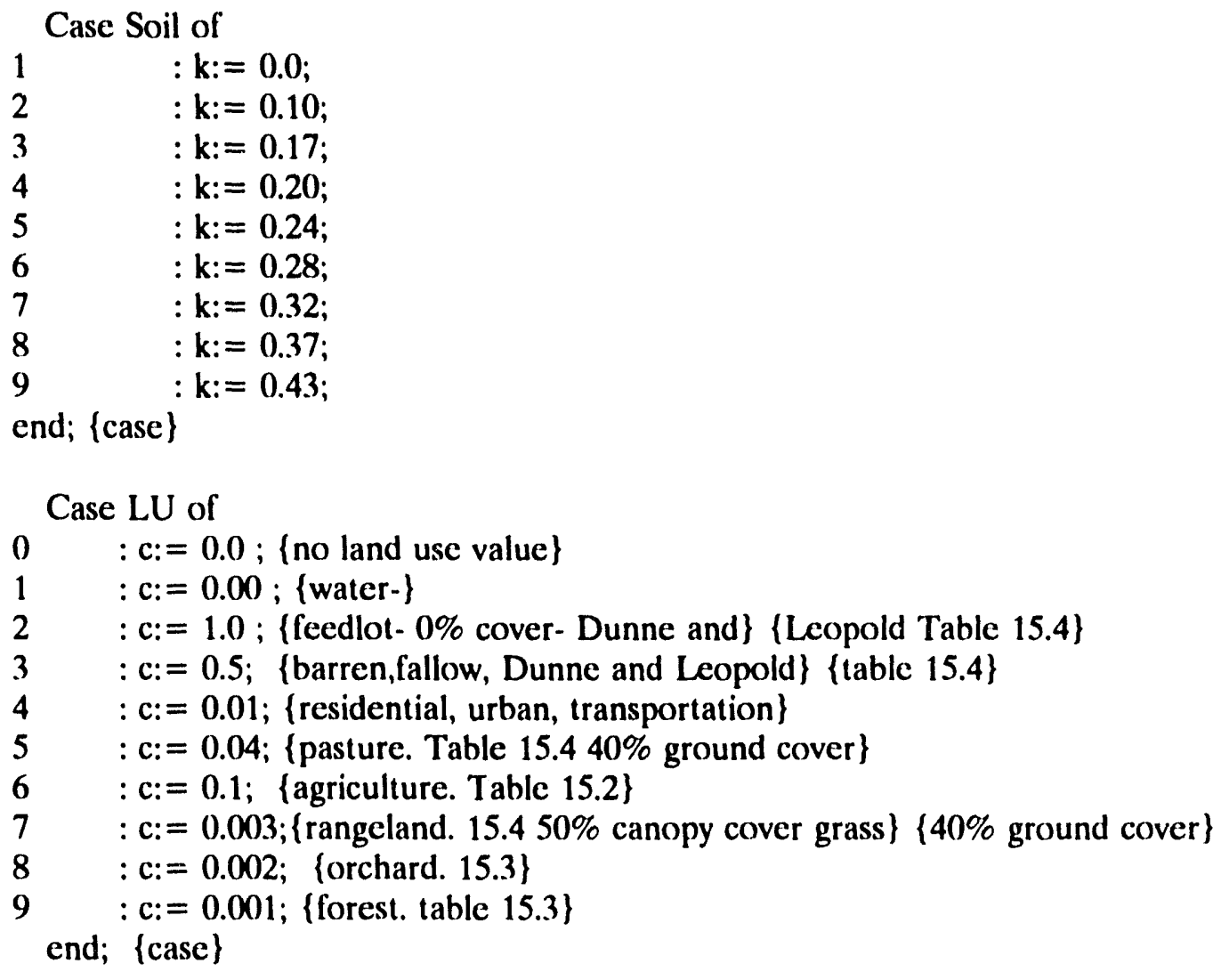

\{slope factor\} 


$$
\begin{aligned}
& \text { slope }:=\text { slope } / 10 \\
& \left.s:=\left(0.43+0.30^{*} \text { slope }+0.043 *(\text { sqr(slope })\right)\right) / 6.574 ; \\
& \text { \{calculate slope expression for corrected I factor\} } \\
& \begin{array}{ll} 
& \\
\text { if slope }<4.0 \text { then } & x:=0.3 \\
\text { else if slope }=4.0 \text { then } & x:=0.4 \\
\text { else if slope }>4.0 \text { then } & x:=0.5
\end{array}
\end{aligned}
$$

\{calculate length factor $\mathrm{L}$ \}

$$
1:=\exp \left(\mathrm{x}^{*} \ln (\operatorname{distance} / 22)\right)
$$

\section{USLEyield $:=(2.24 * R * K * L * S * C * P) / 25$;}

$\{25$ convert from metric tons/ha to metric tons $/ 400 \mathrm{~m} 2$ cell $\}$

if usleyield > max_usle then max_usle := usleyield;

end; Write(outputfile,usleyield);

end;

End; \{Procedure USLELOAD\}

$\{-$

PROCEDURE Read_input_Docfile;

Var

docfile : text;

docname : string[80];

description : string[14];

begin

titleskip : string[66];

docname :=drive + path + input_image +image_docfile_extension; assign(docfile,docname);

reset(docfile);

read(docfile,description); readln(docfile,titleskip); read(docfile,description);readln(docfile,description); read(docfile,description);readln(docfile,description);

read(docfile,description);readln(docfile,rows);

read(docfile,description);readln(docfile,cols);

read(docfile,description);readln(docfile,min);

read(docfile,description);readln(docfile,max); 
read(docfile,description);readln(docfile,cellx);

read(docfile,description);readln(docfile,celly);

close(docfile)

End; \{procedure Read_input_docfile\}

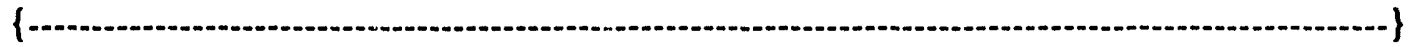

PROCEDURE Read_Environment_File;

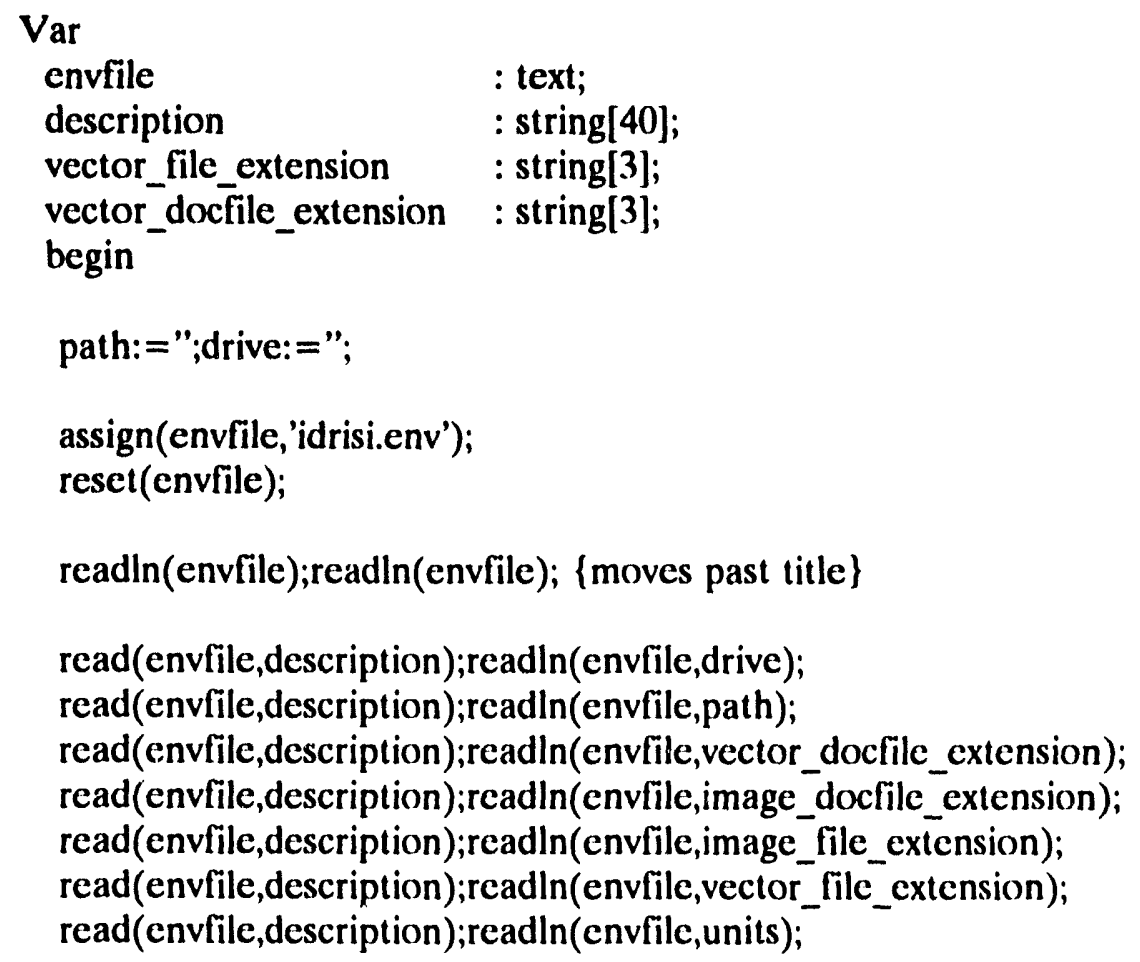

\{note : the environment file contains further information but\} \{this is typically all that is needed\}

close(envfile);

if path ='none' then path:=";

end;

$\{$ \{

\{Main Program\}

BEGIN 
TextAttr := Yellow + Blue * 16;

clrscr;

Writeln('IDRISI: USLE calculates potential sediment yield from each celi');

Writeln('Input file must be binary with real data format.');

Writeln('Output file will be binary with real data format.');

Writeln('Values in resulting image are in metric tons $/ 400 \mathrm{~m} 2$ cell');

Writeln('Programmer: Daniel A. Levine');

Writeln;

Writeln;

Write('Enter the name of the INPUT file..: ');

Readln(input_image);

Write('Enter a value for P- the erosion control factor..:');

Readln(p);

Write('Enter value for the Rainfall Erosivity Index..:');

Readln(r);

Writeln;

Write('Enter the name of the Sediment Load image to be produced..: ');

Readln(output_image);

Writeln('Enter a Title for the Sediment Load image to be produced..: ');

Readln(title);

Writeln;Writeln;Writeln;

Write('The program is running...');

Read_Environment_File;

Read_input_docfile;

inputname $:=$ drive + path +input_image +image_file_extension;

outputname $:=$ drive + path +output_image +image_file_extension;

Assign(inputfile,inputname);

Reset(inputfile);

Assign(outputfile,outputname);

Rewrite(outputfile);

min_usle $:=0.0 ;$ max_usle $:=0.0$

usleload; $\{$ calls procedure usle to calculate sediment loads\}

Close(inputfile);

Close(outputfile);

Create_output_Docfile;

END. 


\section{APPENDIX D}

DELIVERY: a Turbo Pascal program that reads an IDRISI image file with soil, land use, slope, and distance codes and calculates delivery of mass of total phosphorus, total nitrogen, or total suspended solids across each $20-\mathrm{m}$ by $20-\mathrm{m}$ cell. 
PROGRAM DELIVERY; \{Programmer: Daniel A. Levine\}

\{This program takes a file with LANDUSE, SLOPE, and DISTANCE\} \{and Soil codes and calculates a delivery ratio for\} \{phosphorus, nitrogen, or sediment mass transport across each\} \{cell.\}

Uses Crt;

VAR

title

data_type,file_type

rows,cols,legend

$\mathrm{i}, \mathrm{j}$,element

min,max,cellx,celly

min_drat,max_dirat

land,soil

dist,slope

legend_text

path

drive, units

input_image, delrat_image

image_docfile_extension

image_file_extension

inputname, delrationame

INPUTFILE

outputfile

: string[66];

: string[10];

: integer;

: integer;

: real;

: integer;

: integer;

: real;

: array [1.94] of string[40];

: string[40];

: string[2];

: string[8];

: string[4];

: string[4];

: string[80];

:file of real;

: file of byte;

$$
\{
$$

PROCEDURE Create_Delivery_Docfile;

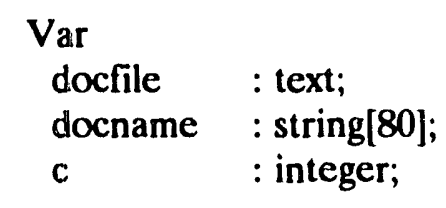

begin

docname: $=$ drive + path + delrat_image + image_docfile_extension; assign(docfile,docname);

rewrite(docfile);

writeln(docfile,'image title : ',title); 


$\begin{array}{ll}\text { writeln(docfile,'data_type } & \text { : byte'); } \\ \text { writeln(docfile,'file_type } & \text { : binary'); } \\ \text { writeln(docfile,'rows } & \text { : ',rows); } \\ \text { writeln(docfile,'columns } & \text { : ',cols); } \\ \text { writeln(docfile,'minimum } & \text { : ',min_drat); } \\ \text { writeln(docfile,'maximum } & \text { :',max_drat); } \\ \text { writeln(docfile,'cell x } & \text { : ',cellx); } \\ \text { writeln(docfile,'cell y } & \text { : ',celly); } \\ \text { writeln(docfile,'legend } & \text { : ',0); }\end{array}$

close(docfile);

END; $\{$ Procedure Create_Delivery_Docfile\}

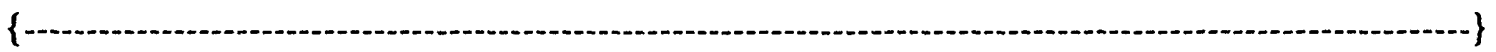

PROCEDURE Deliver;

\{This procedure calculates mass delivery across each cell\}

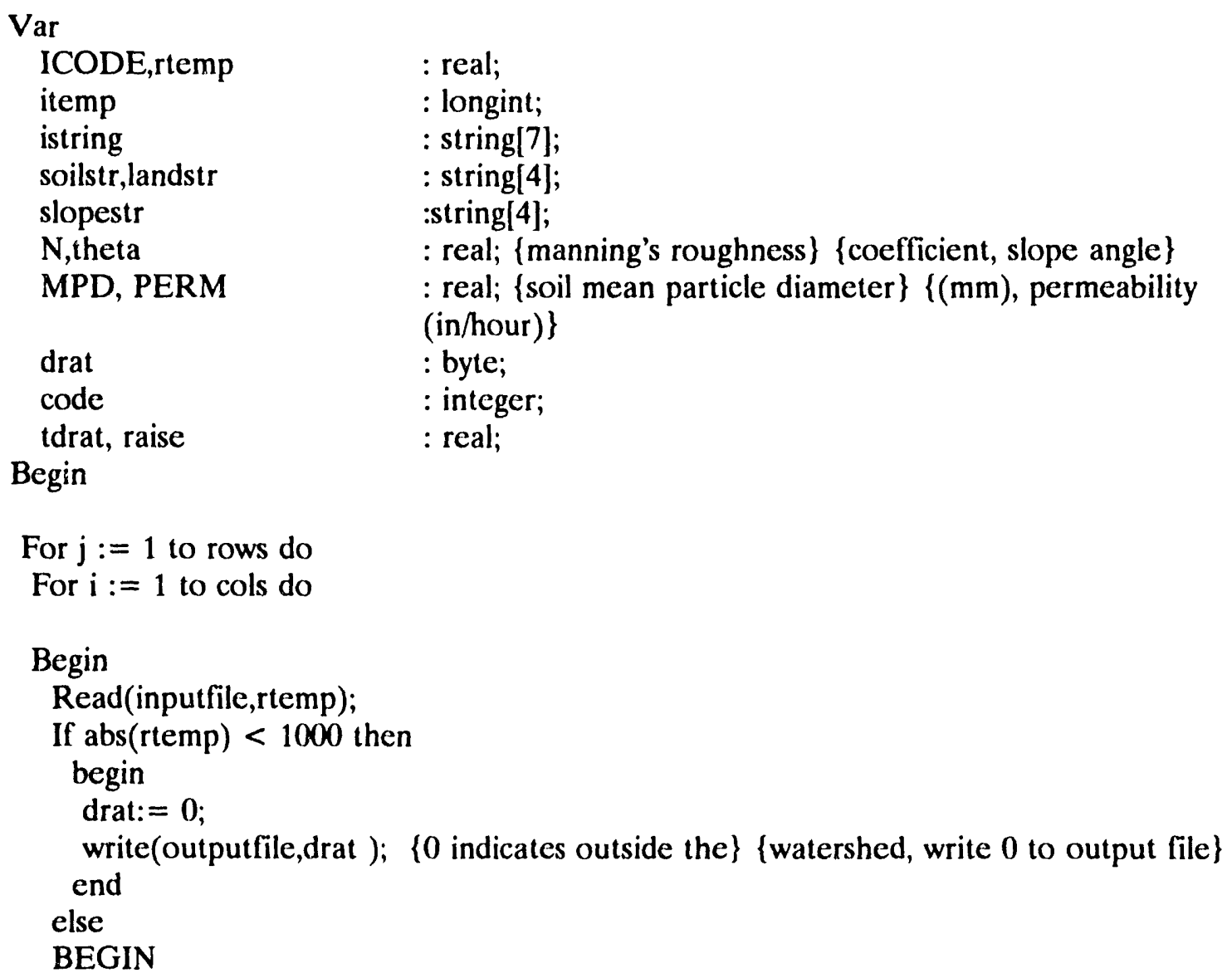

\{this line sets distance of flow. negative means up and down\} \{or side to side 20 meters\} 
\{positive means diagonal flow or 28.28 meters\}

if rtemp $>0$ then dist: $=20^{*}(\operatorname{sqrt}(2))$ \{diagonal flow\} else dist $:=20$; \{rook's case flow\}

$\{$ - -

\{this section take input value and parses value into values\} \{for soil-land use-and slope\} itemp := Round(rtemp*10);

Str(abs(itemp),istring); \{convert itemp to string to break\} \{up into separate codes\}

if $\mathrm{ABS}$ (rtemp) > 9999 then $\quad$ \{five digits to left of decimal\}

begin

soilstr := Copy(istring,1,2); Delete(istring,1,2);

landstr := Copy(istring,1,1); Delete(istring, 1,1);

slopestr := Copy(istring, 1,3$)$;

end

else $\quad$ four digits to left of decimal\}

begin

soilstr := Copy(istring,1,1); Delete(istring,1,1);

landstr := Copy(istring,1,1); Delete(istring, 1,1);

slopestr := Copy(istring, 1,3$)$;

end;

\{convert separate string codes back to numeric values\}

Val(soilstr, soil,code);

Val(landstr, land,code);

Val(slopestr,slope,code);

$\{$ \{

\{transform slope into theta\}

theta:= $\arctan ($ slope $/ 1000)$;

\{assign values for Manning's Roughness Coefficient based on Land Use\}

\{from Engmann 1986 table 7\}

Case Land of 


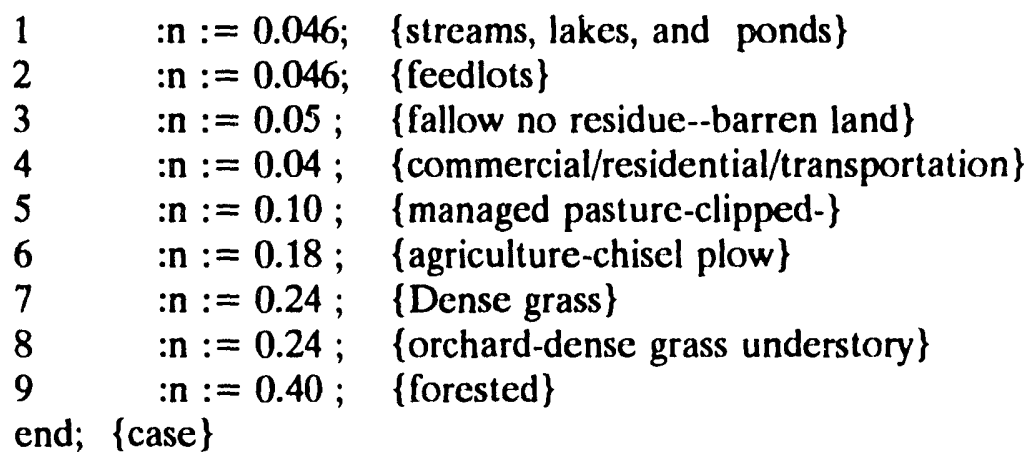

\{assign permeability and MPD values based on soil code\}

Case Soil of

\begin{tabular}{|c|c|c|c|}
\hline 1 & :begin perm: $=0.0$ & mpd: $=0.0$ & ; end; \\
\hline 2 & begin perm: $=0.05$ & mpd: $=0.0785$ & ; end; \\
\hline 3 & :begin perm: $=0.06$ & mpd: $=0.0325$ & ; end; \\
\hline 4 & :begin perm: $=0.06$ & mpd: $=0.0785$ & ; end; \\
\hline 5 & :begin perm: $=0.06$ & mpd: $=0.103$ & ; end; \\
\hline 6 & :begin perm: $=0.20$ & $\mathrm{mpd}:=0.0325$ & ; end; \\
\hline 7 & :begin perm: $=0.20$ & mpd: $=0.0785$ & ; end; \\
\hline 8 & :begin perm: $=0.20$ & mpd: $=0.103$ & ; end; \\
\hline 9 & :begin perm: $=0.20$ & mpd: $=0.115$ & ; end; \\
\hline 10 & :begin perm: $=0.20$ & mpd: $=0.124$ & ; end; \\
\hline 11 & :begin perm: $=0.60$ & $\mathrm{mpd}:=0.0325$ & ; end; \\
\hline 12 & :begin perm: $=0.60$ & $\mathrm{mpd}:=0.103$ & ; end; \\
\hline 13 & :begin perm: $=0.60$ & $\operatorname{mpd}:=0.113$ & ; end; \\
\hline 14 & :begin perm: $=0.60$ & mpd: $=0.124$ & ; end; \\
\hline 15 & :begin perm: $=0.60$ & mpd: $=0.136$ & ; end; \\
\hline 16 & begin perm: $=0.60$ & mpd: $=0.150$ & ; end; \\
\hline 17 & :begin perm: $=0.60$ & $\mathrm{mpd}:=0.163$ & ; end; \\
\hline 18 & :begin perm: $=2.00$ & mpd: $=0.124$ & ; end; \\
\hline 19 & :begin perm: $=2.00$ & $\mathrm{mpd}:=0.150$ & ; end; \\
\hline 20 & :begin perm: $=2.00$ & $\mathrm{mpd}:=0.163$ & ; end; \\
\hline 21 & :begin perm: $=2.00$ & mpd: $=0.175$ & ; end; \\
\hline 22 & :begin perm: $=2.00$ & $\mathrm{mpd}:=0.220$ & ;end; \\
\hline 23 & :begin perm: $=5.00$ & mpd: $=0.150$ & ;end; \\
\hline 24 & begin perm: $=5.00$ & mpd: $=0.163$ & ;end; \\
\hline 25 & begin perm: $=5.00$ & $\mathrm{mpd}:=0.220$ & ;end; \\
\hline 26 & :begin perm: $=5.00$ & $\mathrm{mpd}:=0.250$ & ;end; \\
\hline 27 & :begin perm: $=5.00$ & mpd: $=0.280$ & ;end; \\
\hline
\end{tabular}
end; \{case

$\left\{{ }^{* *}\right.$ - real mpd value above models limit-- value lowered to 5.00\} 
\{This section calculates delivery ratios for $1 \mathrm{TP}, 2 \mathrm{TN}$,$\} \{ or 3$ TSS \}

Case element of

1 : begin

if mpd $=0.0$ then tdrat $:=0.0$

else

begin

raise $:=1.473729994+\left(-0.416001194^{*}\right.$ dist $)$

$+\left(0.012140515^{*}(\right.$ sqr(dist $\left.\left.)\right)\right)$

$+\left(0.298623836^{*}(\right.$ perm $\left.)\right)+\left(-5.739311329^{*}(\mathrm{n})\right)$;

tdrat : $=(1 /(1+(\exp ($ raise $))))$;

end;

end;

2 : begin

if $\mathrm{mpd}=0.0$ then tdrat: $=0.0$

else

begin

raise $:=-10.14100529+\left(0.01679527^{*}\right.$ dist $)$

$+\left(26.83459334^{*}\right.$ theta $)+\left(-4.58233822^{*}(\operatorname{Ln}(\mathrm{n}))\right)$

$+\left(2.86736386^{*}(\operatorname{Ln}(\mathrm{mpd}))\right)+\left(1.47876885^{*}\left(\operatorname{dist}^{*} \mathrm{n}\right)\right)$

$+\left(-1.63440851^{*}\left(\right.\right.$ dist $^{*}$ theta $\left.)\right)$;

tdrat $:=(1 /(1+(\exp ($ raise $))))$;

end;

end;

3 : begin

if perm $=0.0$ then tdrat: $=0.0$

else

begin

raise $:=-3.56563312+\left(-0.32913275^{*}\right.$ dist $)$

$+(0.01129527 *(\mathrm{sqr}(\mathrm{dist})))$

$+\left(22.82483265^{*}\right.$ theta $)+\left(0.73338876^{*}\right.$ perm $)$;

tdrat $:=(1 /(1+(\exp ($ raise $))))$;

end;

end;

end ; $\{$ case $\}$

drat $:=$ Round(100-(Idrat $\left.{ }^{*} 100\right)$ );

if drat > max_drat then max_drat := drat;

Write(outputfile,drat);

end; $\{$ else statement $\}$

End; \{\}

End; \{Procedure Deliver\} 
PROCEDURE Read_input_Docfile;

Var

docfile : text;

docname : string[80];

description : string[14];

begin

titleskip : string[66];

docname :=drive + path +input_image +image_docfile_extension;

assign(docfile,docname);

reset(docfile);

read(docfile,description);readln(docfile,titleskip);

read(docfile,description);readln(docfile,description);

read(docfile,description);readln(docfile,description);

read(docfile,description);readln(docfile,rows);

read(docfile,description);readln(docfile,cols);

read(docfile,description);readln(docfile,min);

read(docfile,description);readln(docfile,max);

read(docfile,description);readln(docfile,cellx);

read(docfile,description);readln(docfile,celly);

close(docfile)

End; \{procedure Read_input_docfile\}

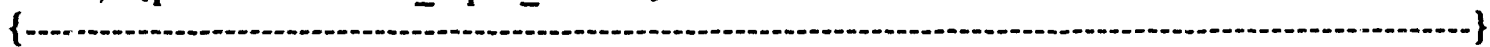

PROCEDURE Read_Environment_File;

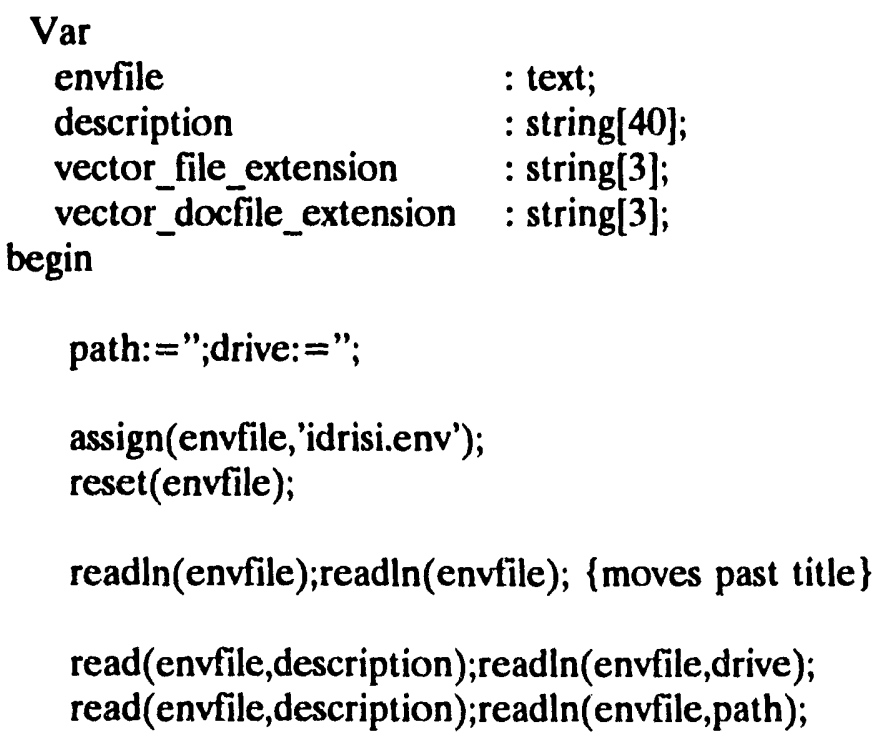


read(envfile,description);readln(envfile,vector_docfile_extension);

read(envfile,description);readln(envfile,image_docfile_extension);

read(envfile,description);readln(envfile,image file_extension);

read(envfile,description);readln(envfile,vector_file_extension);

read(envfile,description);readln(envfile,units);

\{note : the environment file contains further information but\} \{this is typically all that is needed

close(envfile);

if path='none' then path:=";

end;

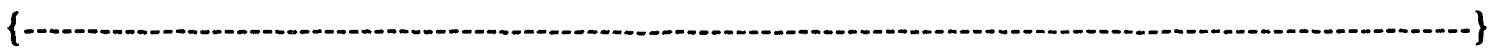

\{Main Program\}

BEGIN

Text Attr := Yellow + Blue $* 16$

Writeln('IDRISI: Delivery calculates transport of nutrients or sediment across each cell');

Writeln('Programmer: Daniel A. Levine');

Writeln;

Writeln(");

Writeln(");

Writeln(");

Writeln(");

Writeln('Input files must be in binary format, output is in byte format');

Writeln('Do you want to calculate delivery ratio for total phosphorus (1)');

Writeln('total nitrogen (2)');

Writeln('or total suspended solids (3)');

Readln(element);

Write('Enter the name of the INPUT image file..: ');

Readln(input_image);

Write('Enter the name of the Delivery Ratio image to be produced..: ');

Readln(delrat_image);

Writeln;

Writeln('Enter a Title for the Delivery Ratio image to be produce..: ');

Readln(title);

Writeln;Writeln;Writeln;

Write('The program is running...');

Read_Environment_File;

Read_input_docfile; 
inputname $:=$ drive + path + input_image +image_file_extension;

delrationame $:=$ drive + path + delrat_image + image_file_extension;

Assign(inputfile,inputname);

Reset(inputfile);

Assign(outputfile,delrationame);

Rewrite(outputfile);

min_drat $:=0 ;$ max_drat $:=0$

Deliver;

Close(inputfile);

Close(outputfile);

Create_Delivery_Docfile;

END. 


\section{APPENDIX E}

FLOPATH: a FORTRAN 77 program that reads the direction of a flow file and a cell delivery file and produces a file of total flow path delivery for each cell in a watershed. 


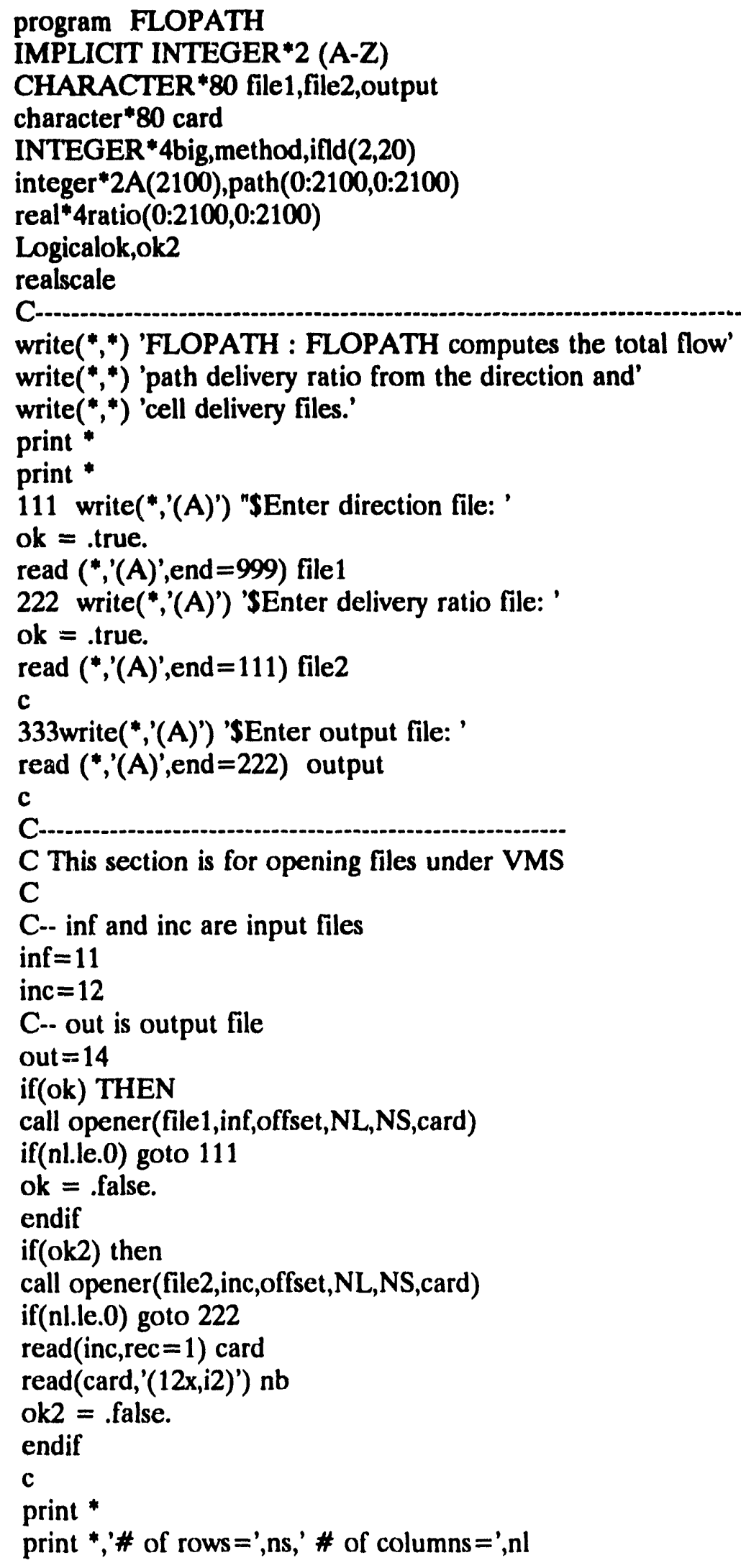


444write (*,'(A)') 'SEnter seed cell row and column: ' read $(*$, ,end $=333$,err $=444)$ irow,jcol

if(irow.le.0.or.jcol.gt.nl) goto 444

c

$\operatorname{card}(21: 32)=$ 'FLOPATH'

call openew(output,out,offset,NL,NS,nb,card,inc)

print *

555 write $(*, '(A)$ ')

*'SChoose method, Sum of 1/Ratio (1) or * (2) or + (3):'

read $\left({ }^{*},(A) '\right.$,end $=444$,err $\left.=555\right)$ card

nof $=$ nfld(card,ifld)

if(nof.ne.0) read(card, ${ }^{*}$ method

if(method.eq.0) goto 555

scale $=.01$

666continue

if(method.eq. 1)

* write $\left({ }^{*},(A)\right.$ ') '\$Enter numerator for sum $1 / R$ : '

if(method.eq.1)

* write(*,'(A)') '\$Enter data scalar (.01) : '

read $(*,(A)$, end $=555$,err $=666)$ card

nof $=$ nfld (card,ifld)

if(nof.ne.0) read(card, $\left.{ }^{*}\right)$ scale

C

$\mathrm{C}-1$.

big $=0$

$\mathrm{nsl}=\mathrm{ns}+1$

$\mathrm{nll}=\mathrm{nl}+1$

call FLOWORK(A,path,ratio,ns,nl,nsl,nll,inf,inc,out,

*offset,big,irow,jcol,scale,method)

$\operatorname{read}($ out,rec $=2)$ card

write(card(61:80),'(2i10)') 0,big

write (out,rec $=2$ ) card

c

print *,'>> $>$ FLOPATH COMPLETED $<<<$ '

print *,' output file :',OUTPUT(1:40)

c

999stop

end

subroutine FLOWORK(A,path,ratio,ns,nl,nsl,nll,

*inf,inc,out,q,big,irow,jcol,scale,method)

implicit integer*2 (A-Z)

logicaldown

integer*4big,method

integer*2path(0:nsl,0:nll)

integer*2A(ns), listc(200000), listr(200000)

*listp (200000)

real* 4rlast,scale,small, huge,ratio(0:nsl,0:nll)

c 
cRead in path (direction file and cConstruct ratio

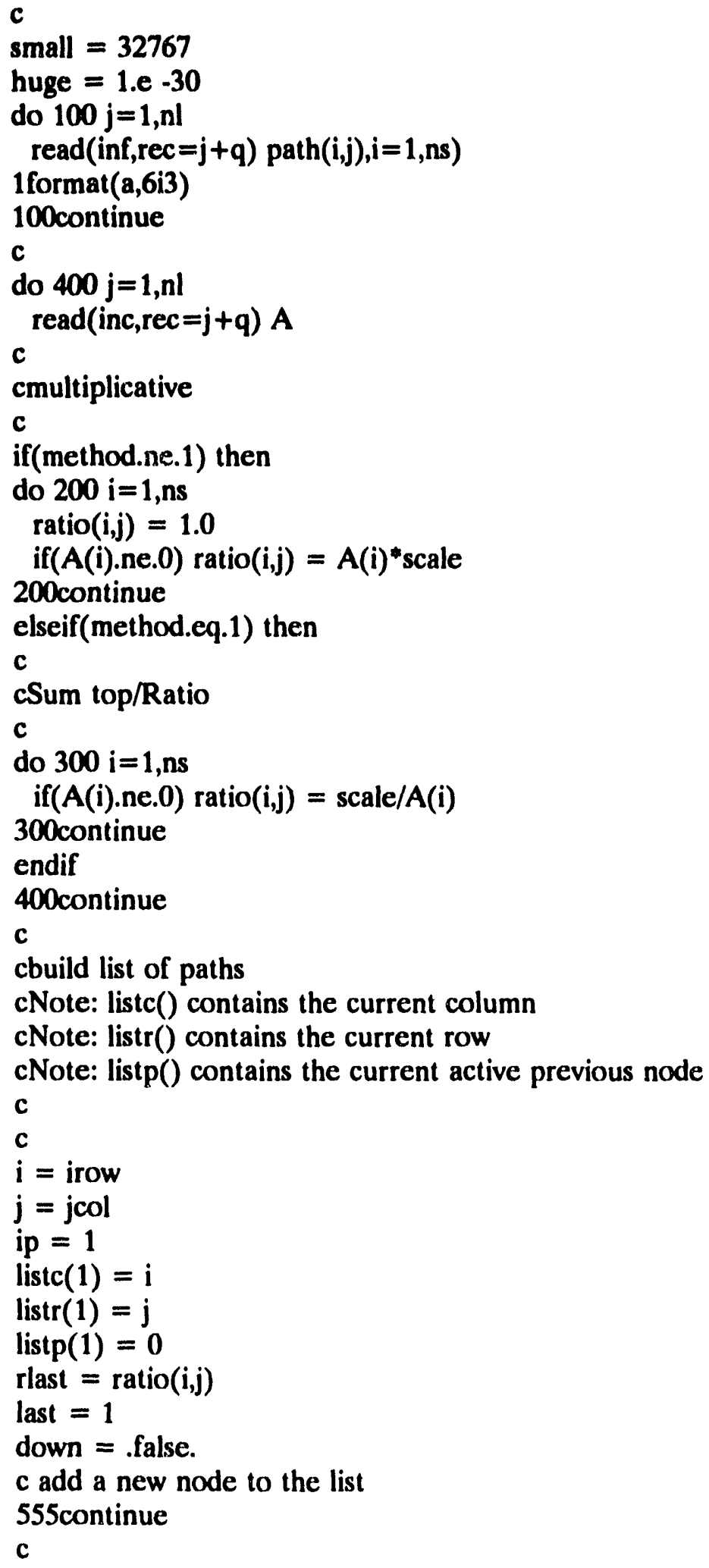




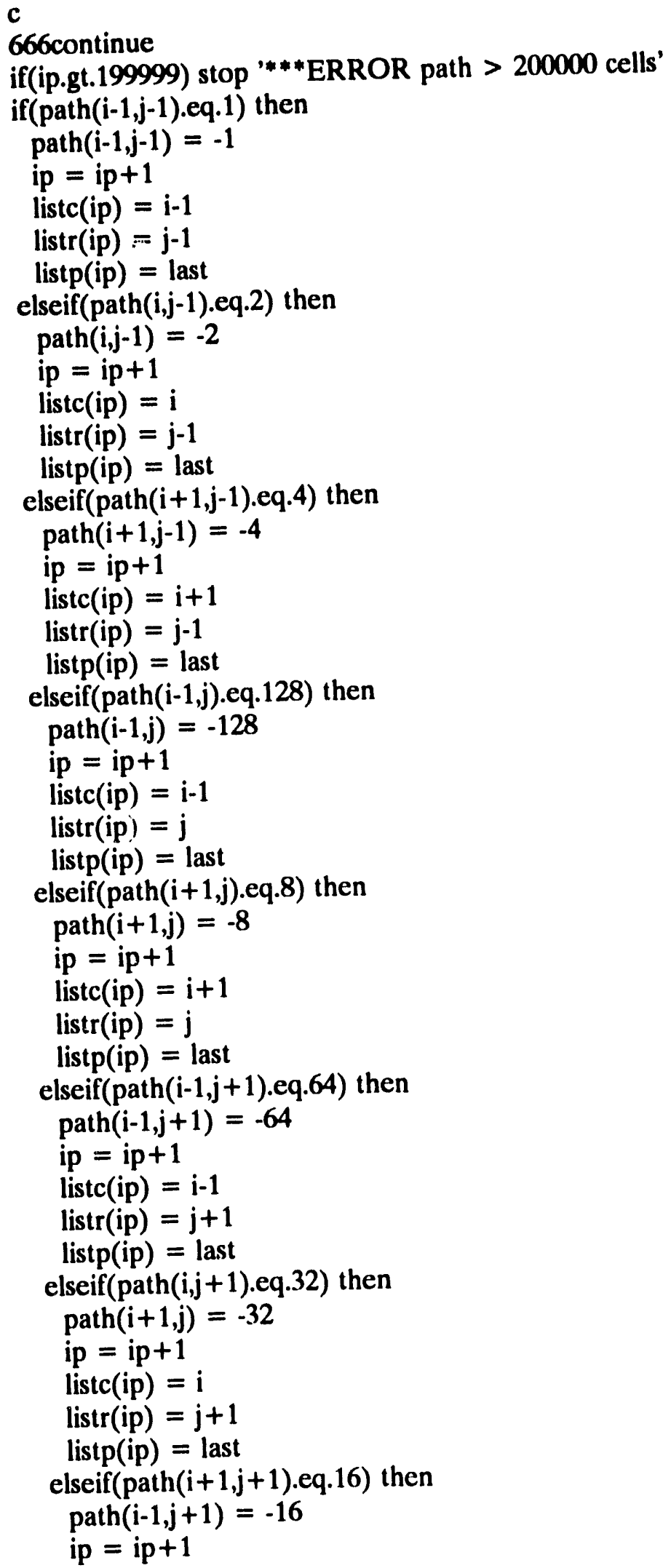




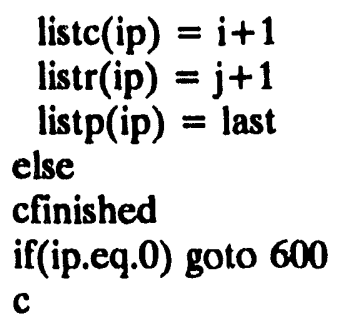

cthis is a leaf, so back up to last node

c

ip $=$ listp(ip)

down =.true.

endif

c

cwe have added a node, so calculate ratio

c

if(.not.down) then

$\mathrm{i}=\operatorname{listc}(\mathrm{ip}$

$\mathrm{j}=$ listr(ip)

if (method.eq. 2$)$ ratio(i,j) $=$ ratio(i,j) $*$ rlast

if $($ method.ne. 2$) \operatorname{ratio}(i, j)=\operatorname{ratio}(i, j)+$ rlast

rlast $=$ ratio(i,j)

if(rlast.ne.0.0) small = aminl(small,rlast)

huge $=$ amaxl(huge,rlast)

last $=\mathrm{ip}$

goto 555

else

c

cwe are going down the tree, so continue searching for new $\mathrm{c}$ branches

c

$\mathrm{i}=\operatorname{listc}(\mathrm{ip})$

$\mathrm{j}=\operatorname{listr}(\mathrm{ip})$

rlast $=$ ratio $(i, j)$

last $=\mathrm{ip}$

down $=$.false.

goto 666

endif

ccomplete, be zeroing unvisited cells and scaling

600 continue

c

path(irow,jcol) $=-$ path(irow,jcol)

print *,'Data range before scaling ( $\& 1 / \mathrm{R}$ if necessary)'

print *,'Small=',small,' Big ',huge

scale $=1 . /$ scale

do $1000 \mathrm{j}=1, \mathrm{nl}$

cmultiplicative

if(method.ne.1) then

do $700 \mathrm{i}=1$,ns

$A(i)=0.0$ 


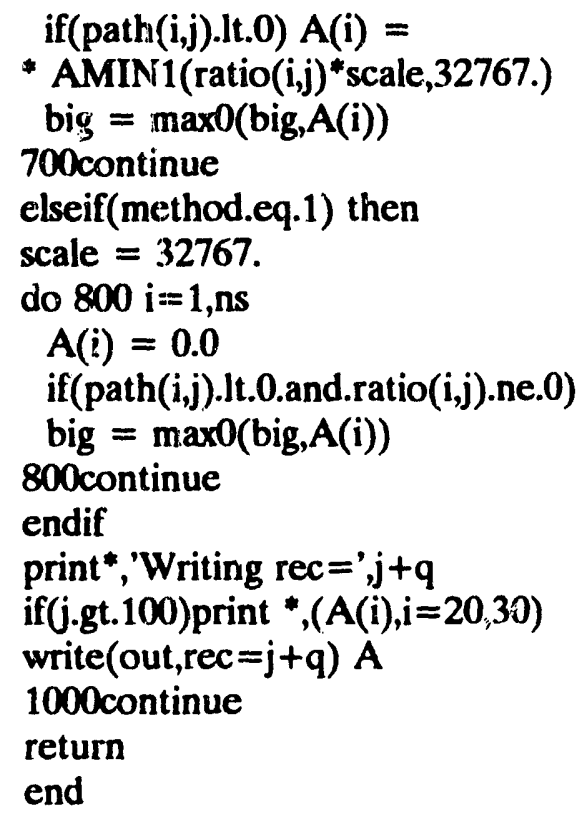




\begin{abstract}
APPENDIX F
Calculations of observed total annual mass loads for total suspended solids (TSS), total phosphorus (TP), and total nitrogen (TN) for twelve watersheds in the Lake Ray Roberts watershed for the year from November 1985 through October 1986. Date refers to date that samples were taken. Interval represents the number of days around the sampling date that the load estimate represents. Load was calculated by multiplying the interval with the discharge and concentration for each sampling date. This product was multiplied by 86400 to convert to units of grams/interval. The bottom line in each table under each pollutant load represents the total annual load (gm/yr) and is the sum of all the numbers in the column. Blank entries indicate that no data were collected on that date, cither because there was no flow or it was too dangerous to enter the stream to collect a sarn ole.
\end{abstract}

A. Annual loads for the IDB1 watershed.

B. Annual loads for the IDB2 watershed.

C. Annual loads for the IDB3 watershed.

D. Annual loads for the Buck Creek watershed.

E. Annual loads for the Timber Creek watershed.

F. Annual loads for the Indian Creek watershed.

G. Annual loads for the Wolf Creek watershed.

H. Annual loads for the TR1 watershed.

I. Annual loads for the TR2 watershed.

J. Annual loads for the TR3 watershed.

K. Annual loads for the TK4 watershed.

L. Annual loads for the Spring Creek watershed. 


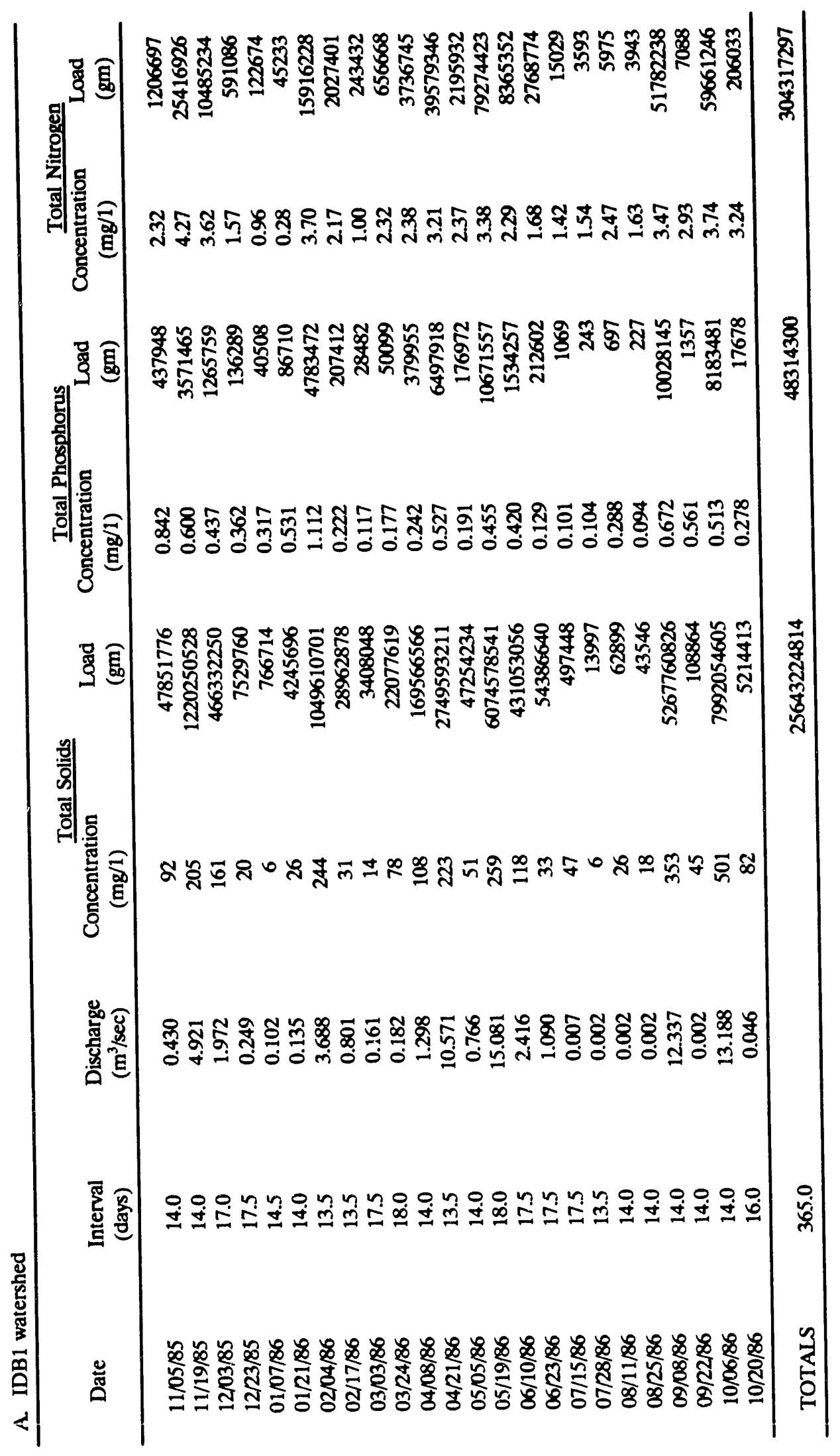




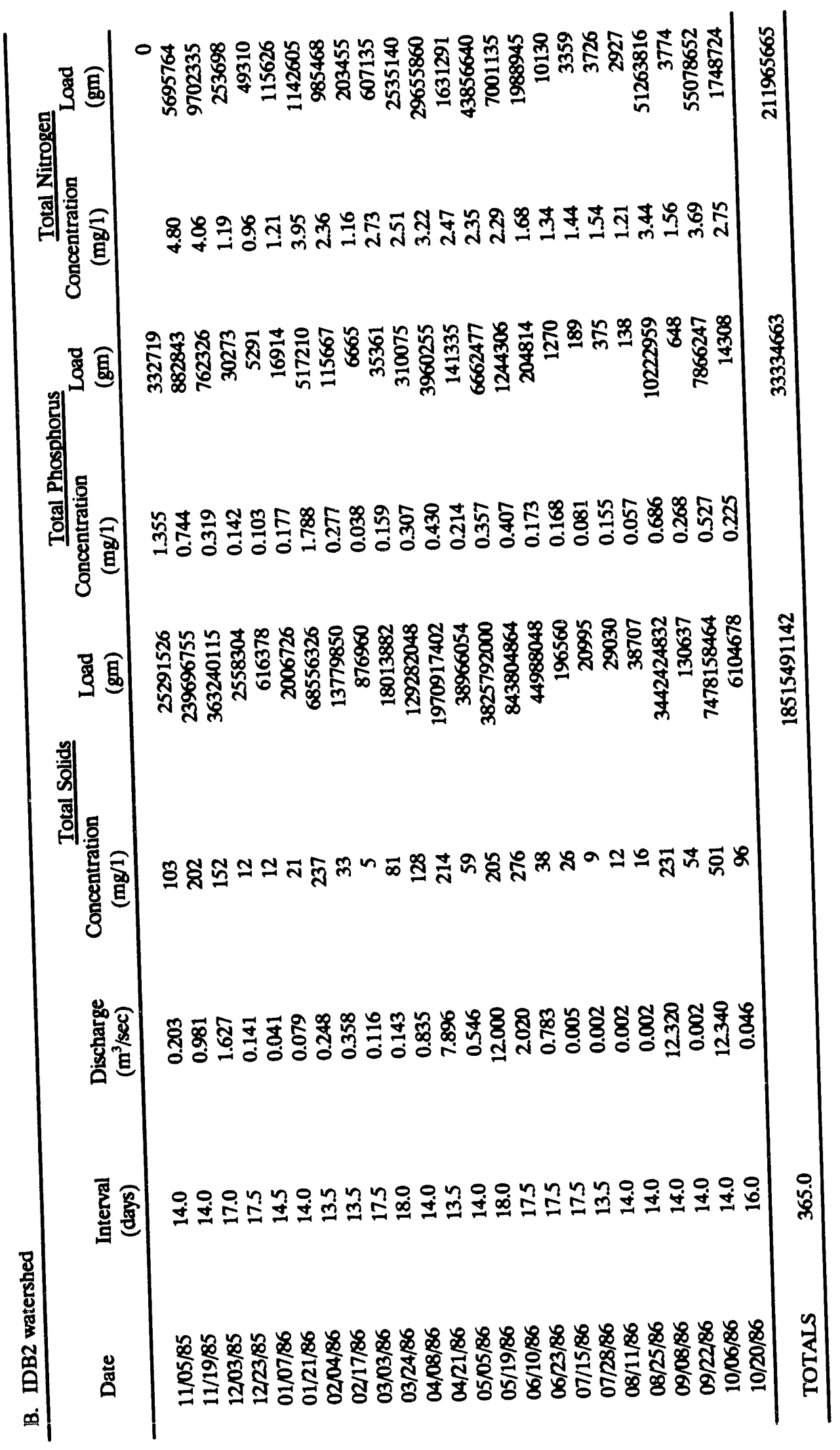




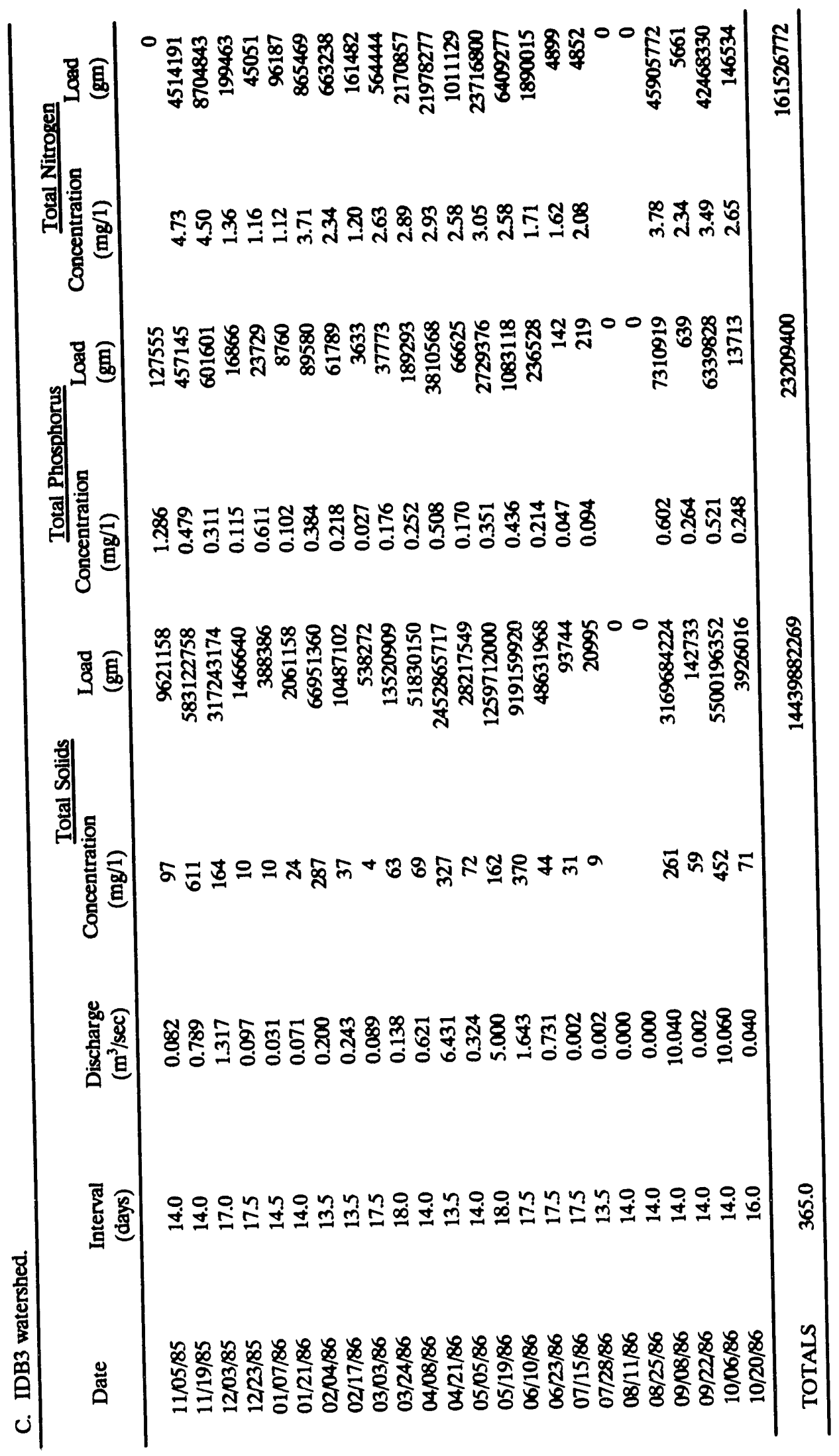




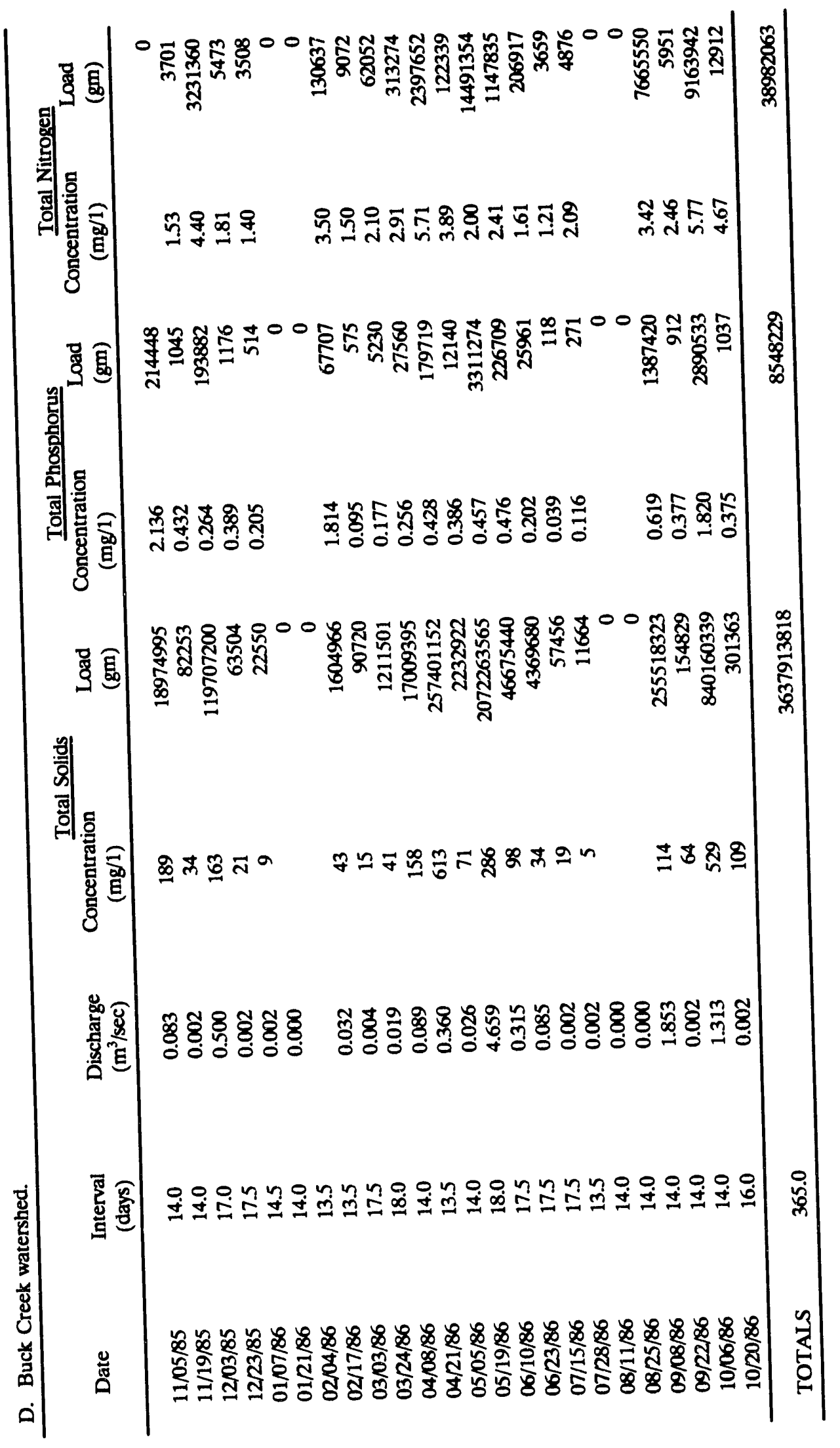




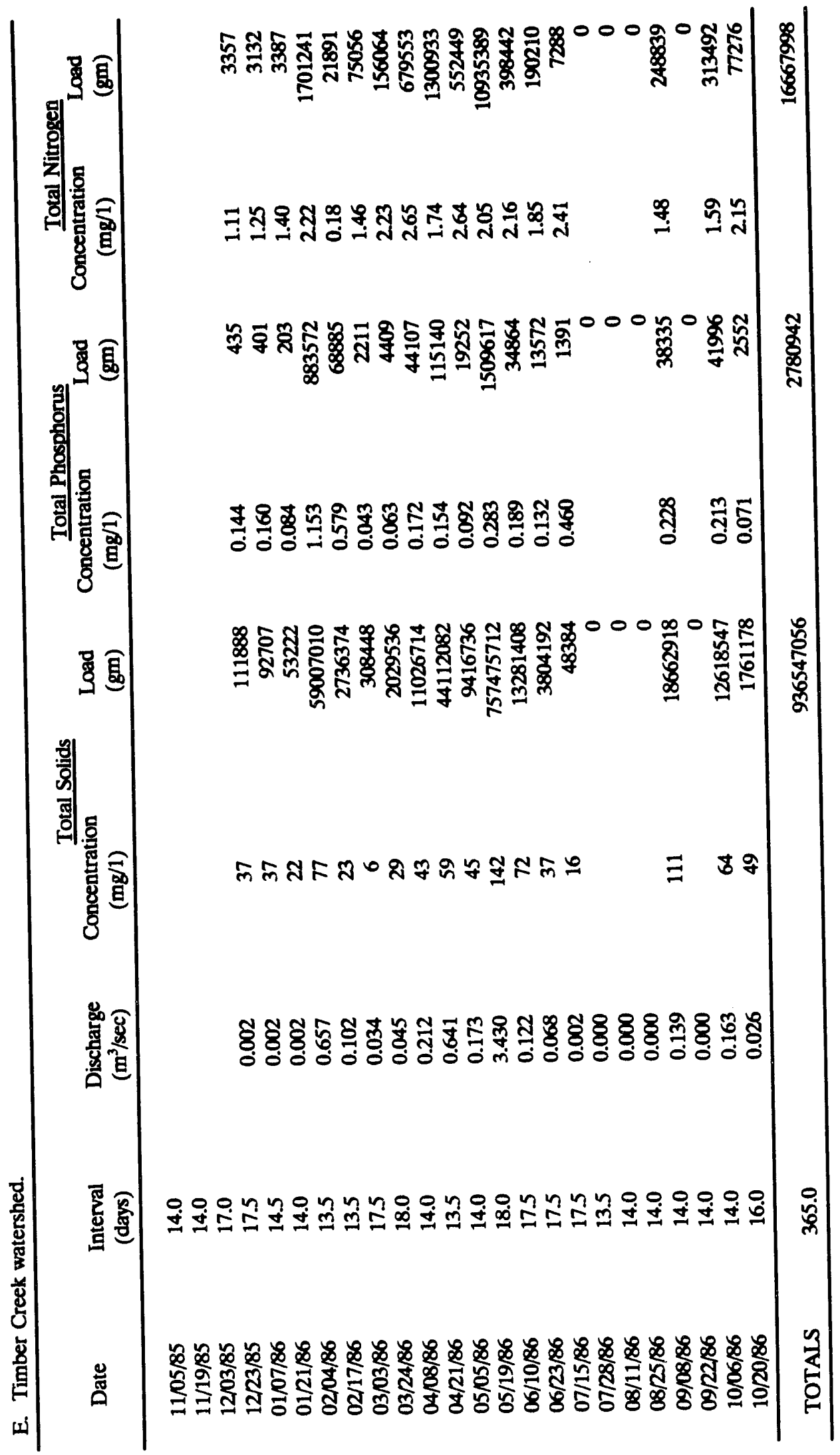




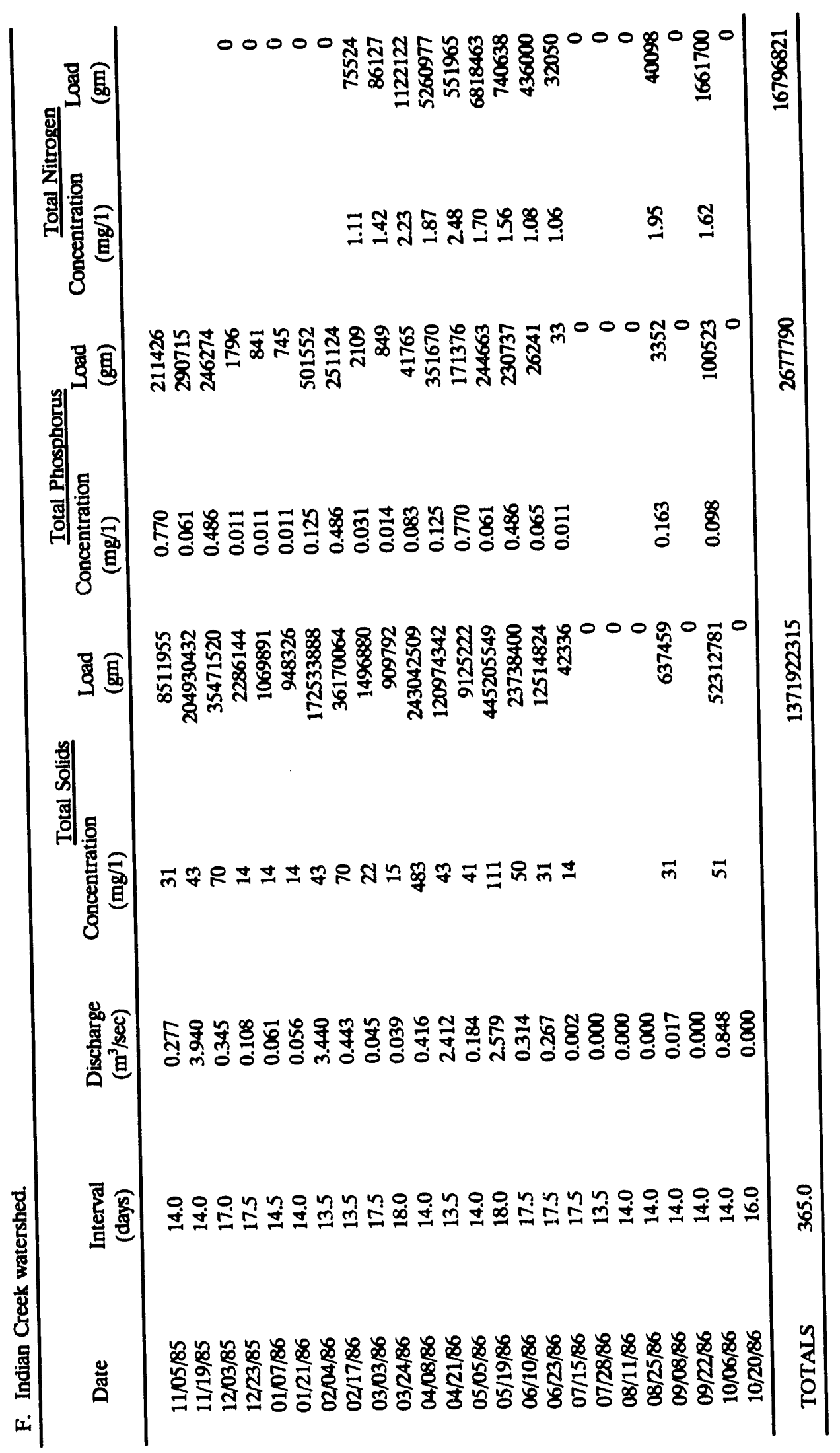




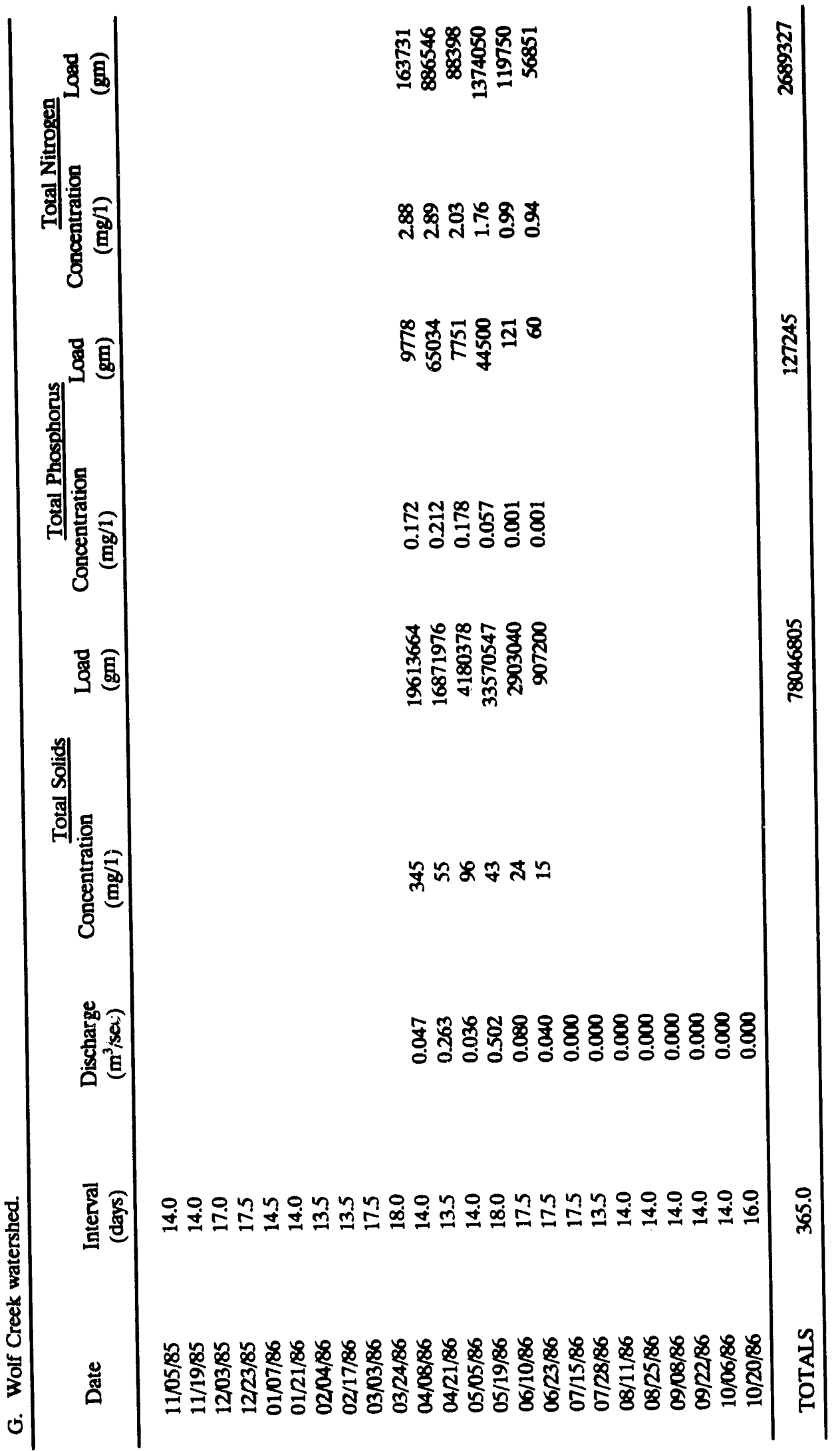




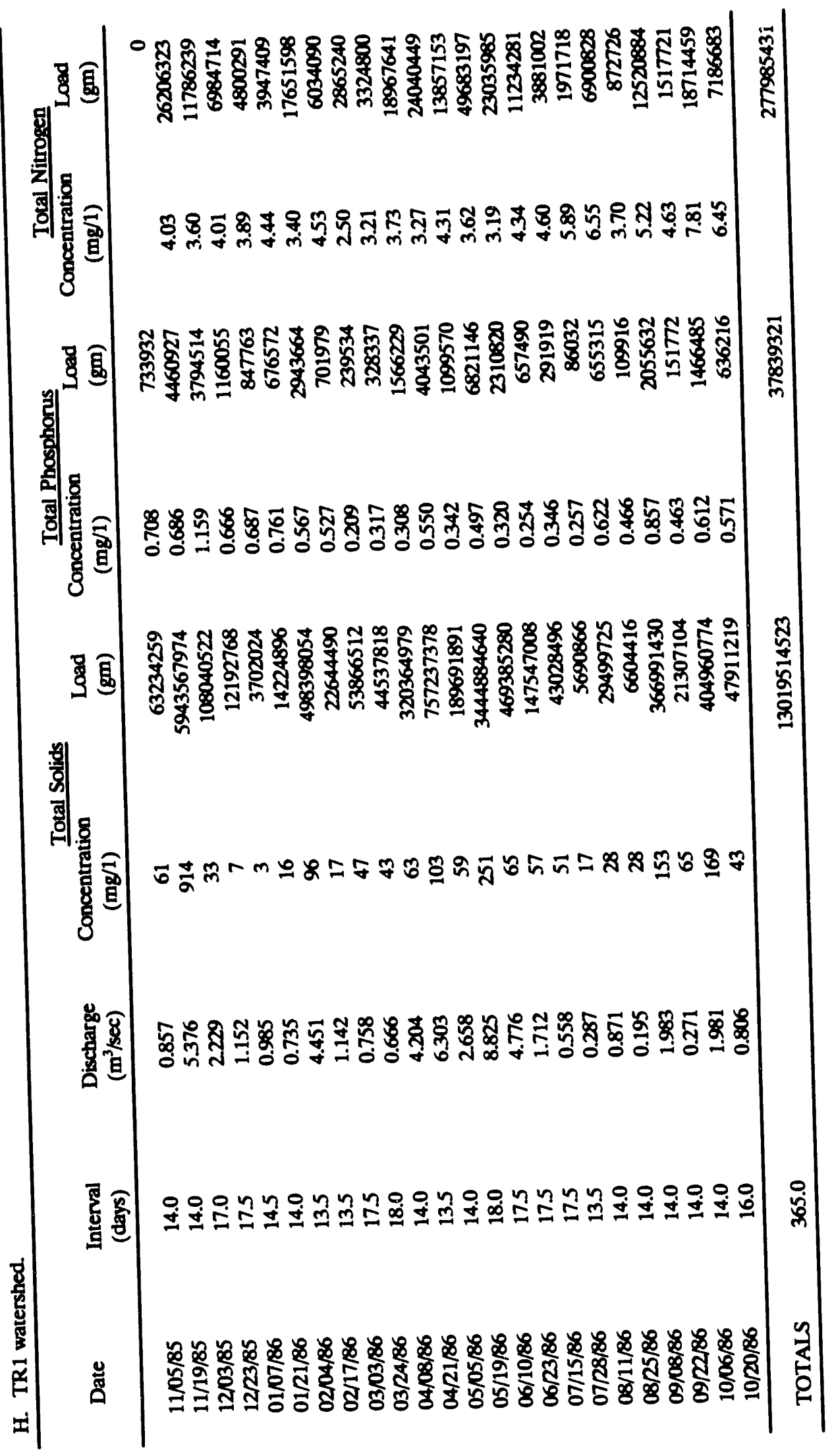




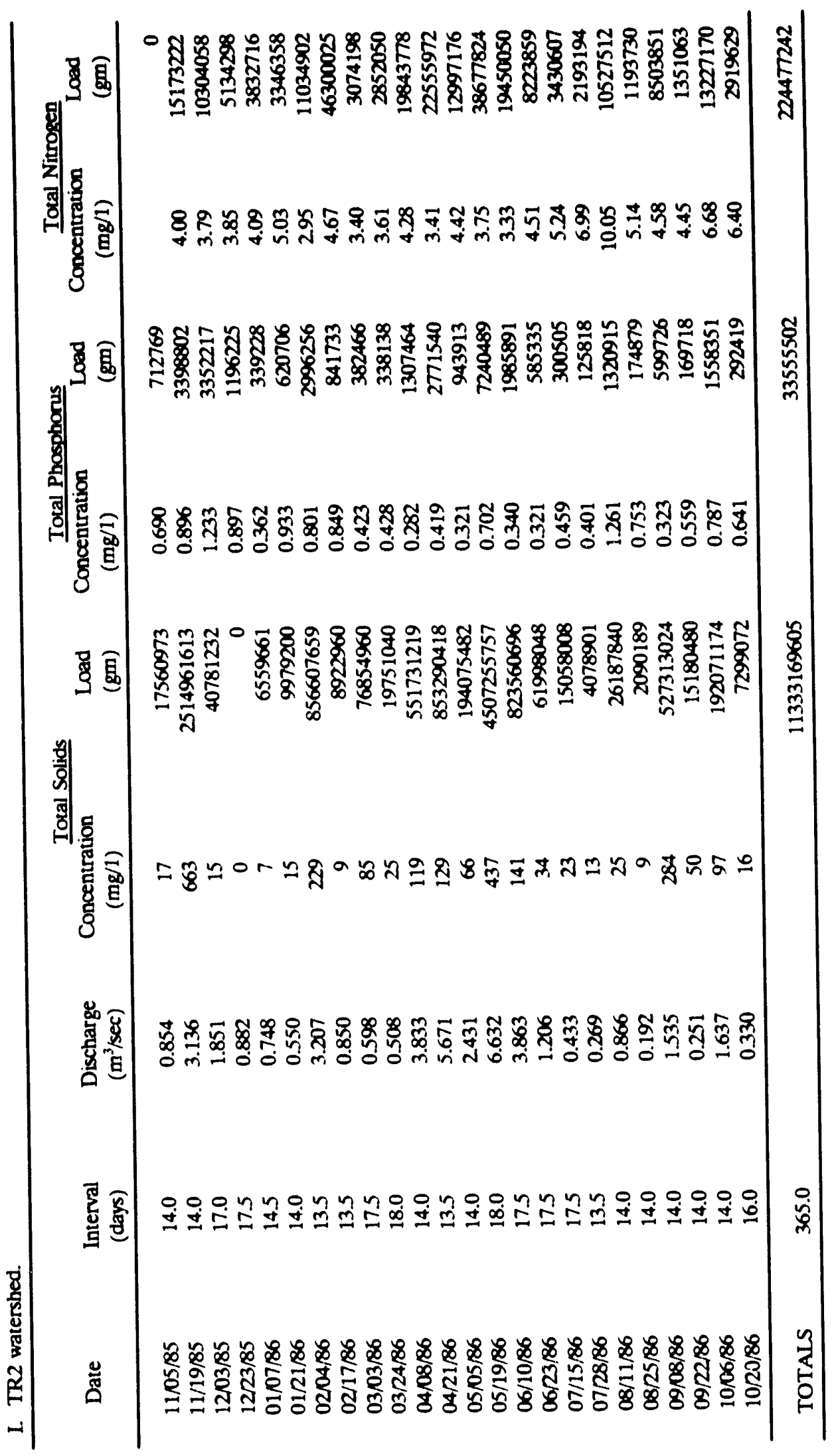




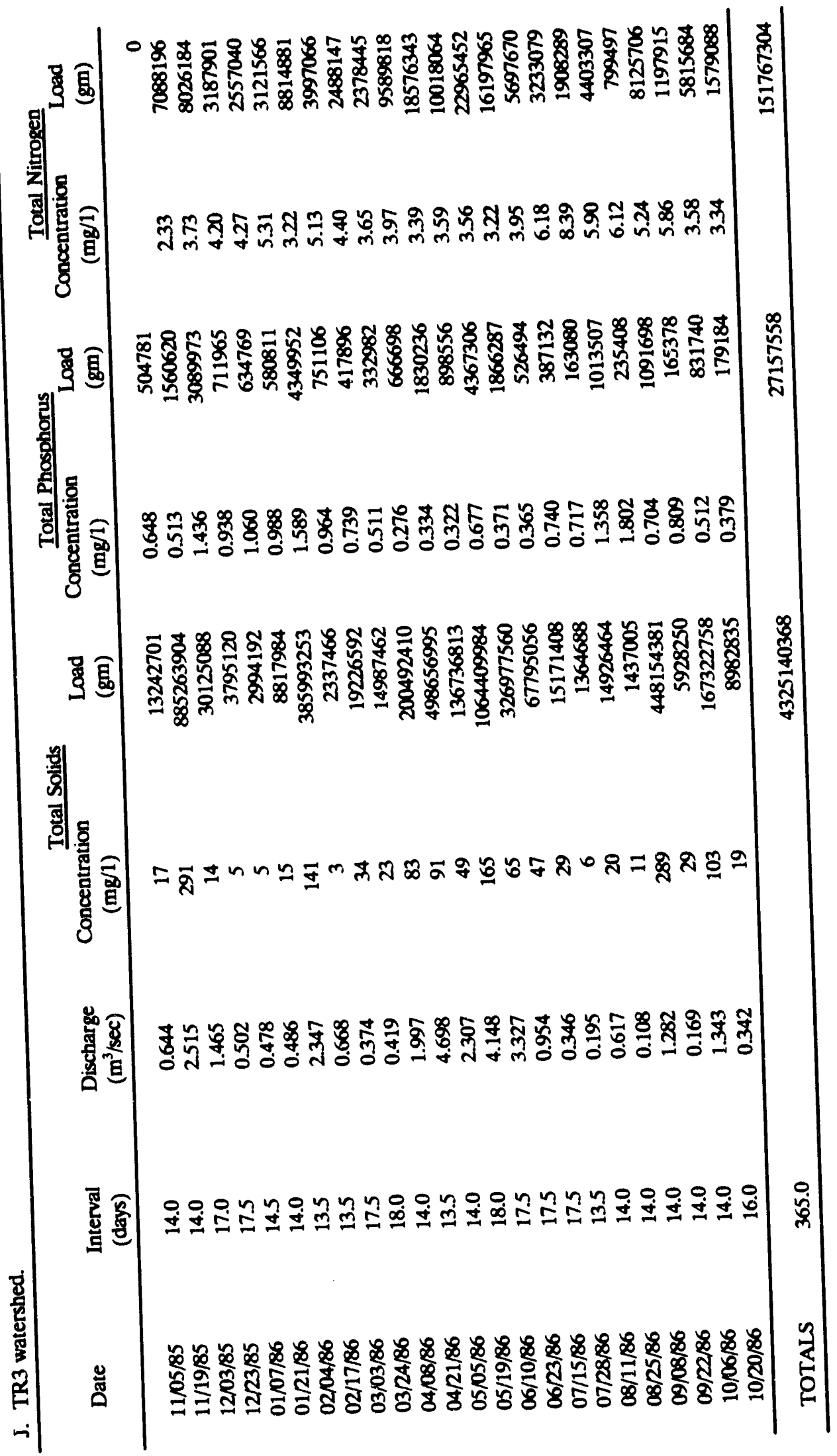




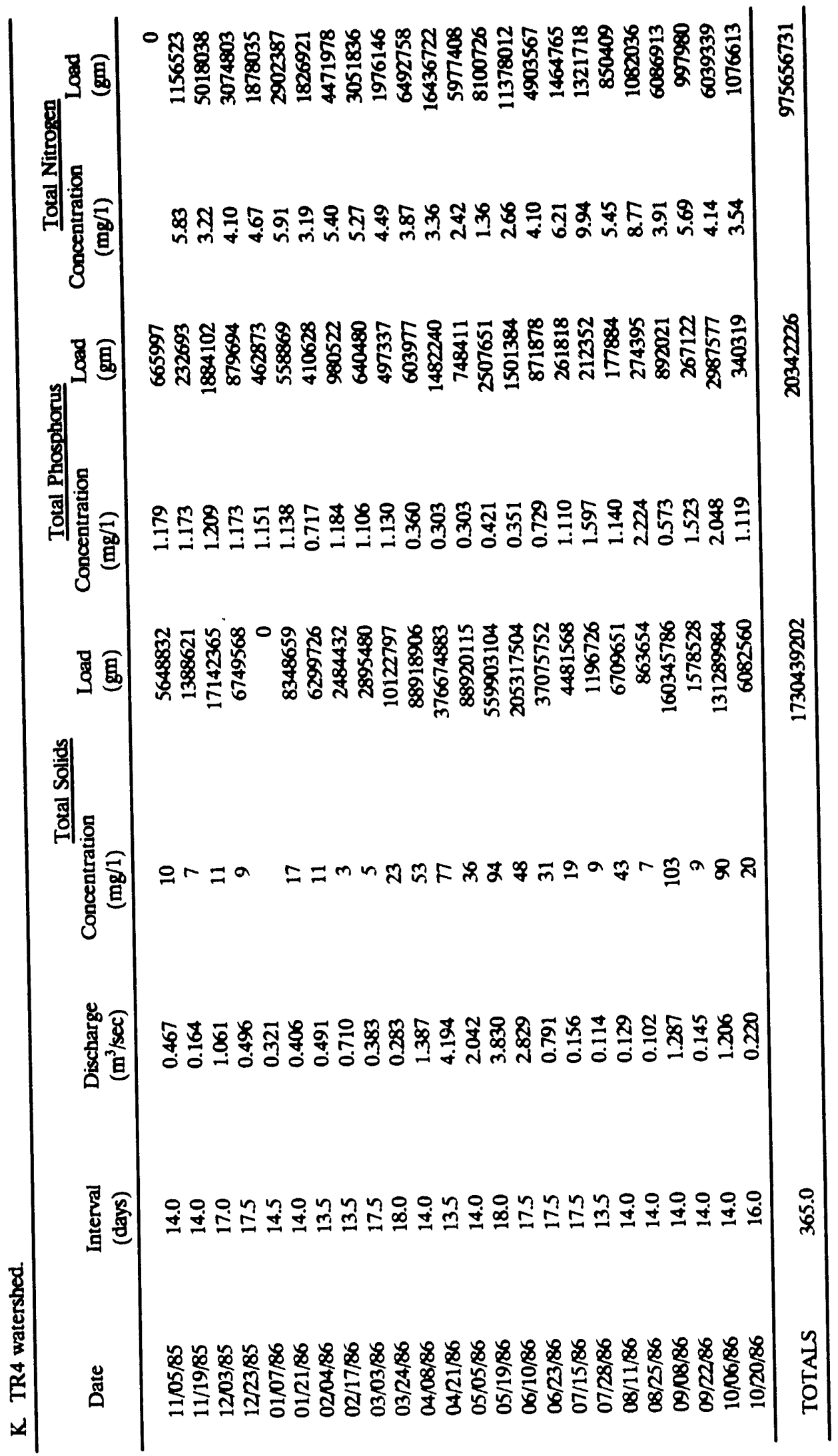




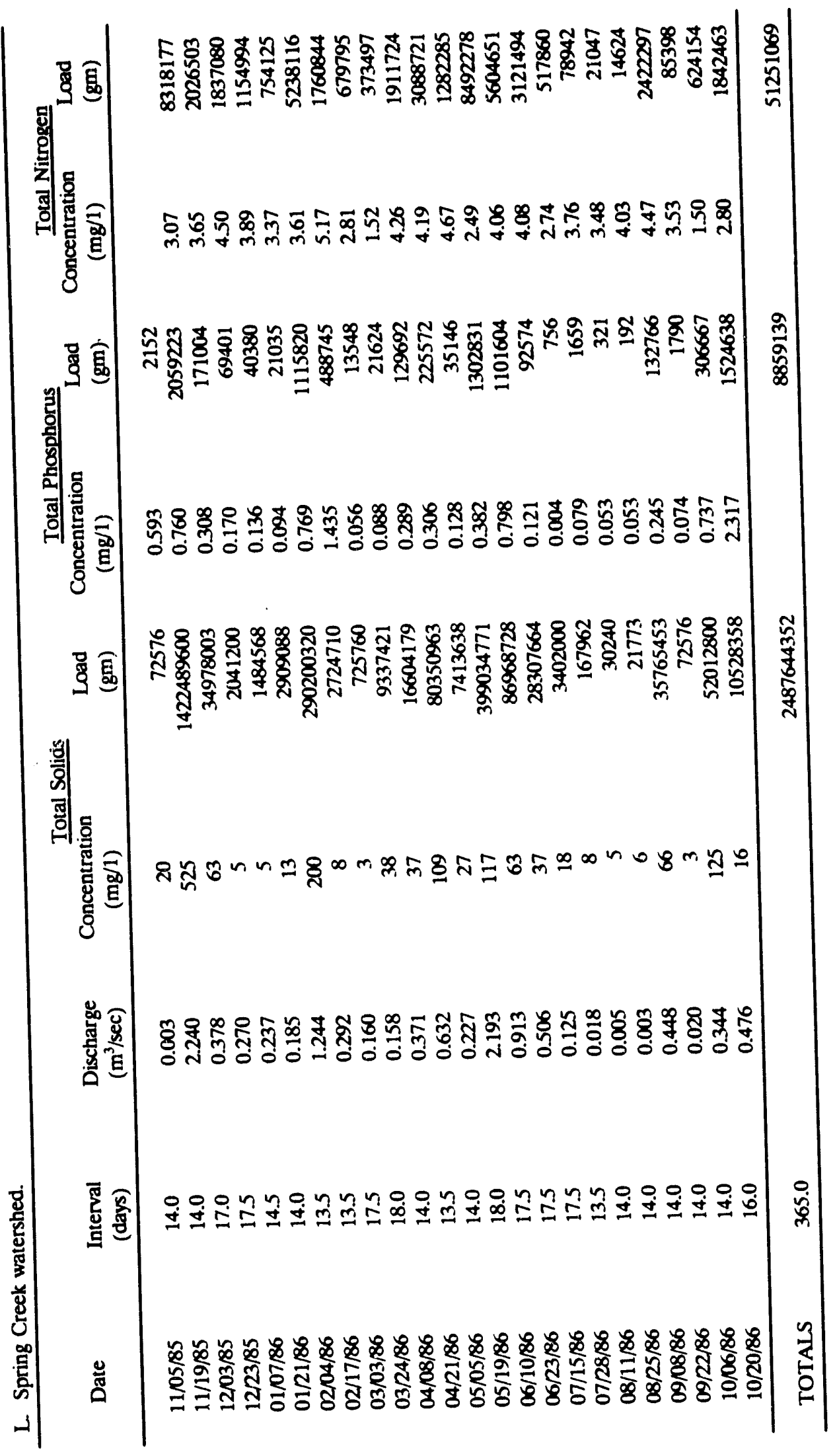




\section{INTERNAL DISTRIBUTION}

1. L. D. Bates, K-1009, MS-7169

2. J. J. Beauchamp, 1505, MS-6036

3. J. B. Cannon, 4500 N, MS-6189

4. R. B. Cook, 1505, MS-6038

5. J. H. Cushman, 1503, MS-6351

6. R. O. Flamm, 1505 MS-6038

7. T. A. Fontaine, 1505 , MS-6038

8. D. E. Flowers, 1505, MS-6035

9. C. W. Gehrs, 1505 , MS-6036

10 S. G. Hildebrand, 1505 , MS-6035

11-40. C. T. Hunsaker, 1505, MS-6038

41. P. Kanciruk, 0907, MS-6490

42-46. D. A. Levine, 1505, MS-6038

47. P. J. Mulholland, 1505, MS-6036

48. R. V. O'Neill, 1505, MS-6036

49. D. E. Reichle, $4500 \mathrm{~N}$, MS-6253

50. F. E. Sharples, 1505, MS-6036

51. D. S. Shriner, 1505, MS-6038

52. S. H. Stow, 1505 , MS-6038

53. S. P. Timmins, 1505 , MS-6038

54. R. S. Turner, 1505, MS-6038

55. R. I. Van Hook, 1505, MS-6037

56. R. F. Winterfield, 1505, MS-6035

57. M. A. Wood, 1505, MS-6035

58-72. ESD Library (15)

73-74. Laboratory Records Dept.

75. Laboratory Records, ORNL-RC

76. ORNL Patent Section

77. ORNL Y-12 Technical Library 


\section{EXTERNAL DISTRIBUTION}

78. S. Atkinson, Institute of Applied Sciences, P.O. Box 13078, Denton, Texas 76203-3078

79. C. Barber, U.S. EPA/ERL, College Station Road, Athens, GA 30613

80. B. J. Barfield, Prof. Agriculture Engineering, Water Resouces Research Inst., Director, University of Kentucky, 219 Anderson Hall, Lexington, KY 40506

81. S. Bolton, University of Washington, College of Forest Resources, ARV4,33 10, Seattle, WA 98195

82. N. E. Carriker, Tennessee Valley Authority, Water Quality Dept., 1101 Market St. HB-2C, Chattanooga, TN 37402-2801

83. D. Correll, Smithsonian Environmental Resource Center, Box 28, Edgewater, MD 21037

84. K. L. Dickson, Institute of Applied Sciences, P.O. Box 13078, Denton, TX 76203-3078

85. T. Dillaha, Agricultural Engineering Department, Virginia Tech, Blacksburg, VA 24061-0303

86. B. Engel, School of Agricultural Engineering, Purdue University, West Lafayette, IN 47907

87. S. E. Franson, USEPA-EMSL-LV/EAD, P.O. Box 93478, Las Vegas, NV 89193-3478

88. J. F. Franklin, Bloedel Professor of Ecosystem Analysis, College of Forest Resources, University of Washington, Anderson Hall AR-10, Seattle, WA 98195

89. R. Gant, Automated Sciences Group, Inc., Jackson Plaza, Suite C-102

90. W. Gilliam, Soil Science Department, Box 7619, North Carolina State University, Raleigh, NC 27695

91. R. Glici, Agricultural Engineering, Texas A\&M University, College Station, TX 77843 
92. R. C. Harriss, Institute for the Study of Earth, Oceans, and Space, Science and Engineering Research Building, University of New Hampshire, Durham, NH 03824

93. W. Heck, USDA/ARS Air Quality, NCSU, 1509 Varsity Drive, Raleigh, NC 27606

94. B. Hubbard, SE Watershed Lab, USDA-ARS, P.O. Box 946, Tifton, GA 31794

95. B. Johnson, Ecology Division, U.S. Fish and Wildlife Service, P.O. Box 818, LaCrosse, WI 54602

96. W. Jones, SPEA, Indiana University, Bloomington, IN 47405

97. G. Y. Jordy, Director, Office of Program Analysis, Office of Energy Research, ER-30, G-226, U.S. Department of Energy, Washington, DC 20545

98. R. W. Kortmann, Ecosystem Consulting Service, Inc., 430 Talcott Hill Road, Coventry, CT 06238

99. R. Lowrance, southeast Watershed Research Laboratory, USDA-ARS, P.O. Box 946, Tifton, GA 31794

100. E. Martinko, U.S. EPA/OMMSQA (RD-680), Washington, D.C. 20460

101. D. McKenzie, U.S. EPA/ERL, 200 SW 35th Street, Corvallis, OR 97333

102. R. J. Naiman, Center for Streamside Studies, AR-10, University of Washington, Seattle, WA 98195

103. D. Newberry, Management Options, 152 Broadway, Apt. 3, Arlington, MA 02174

104. R. H. Olsen, Professor, Microbiology and Immunology Department, University of Michigan, Medical Sciences II, \#5605, 1301 East Catherine Street, Ann Arbor, MI 48109-0620

105. A. Patrinos, Director, Environmental Sciences Division, Office of Health and Environmental Research, ER-74, U.S. Department of Energy, Washington, DC 20585

106. S. Paulsen, U.S. EPA/ERL, 200 SW 35th Street, Corvallis, OR 97333

107. K. Poiani, 409 Wing Hall, Cornell University, Ithaca, NY 14853

108. J. C. Randolph, SPEÁ, İndiana Üniversity, Bloomington, IN 47405 
109. B. Rashleigh, SPEA, Indiana University, Bloomington, IN 47405

110. K. Reckhow, Duke University, School of Forestry \& Environmental Studies, Durham, NC 27706

111. E. Seabloom, 1007 N. Second St., Armes, IA 50010

112. F. J. Wobber, Environmental Sciences Division, Office of Health and Environmental Research, ER-74, U.S. Department of Energy, Washington, DC 20585

113. M. L. Wolfe, Agricultural Engineering Department, Texas A\&M University, College Station, TX 77843-2121

114. Office of Assistant Manager for Energy Research and Development, U.S. Department of Energy Oak Ridge Field Office, P.O. Box 2001, Oak Ridge, TN 37830-8600

115-116. Office of Scientific and Technical Information, P.O. Box 62, Oak Ridge, TN 37831 

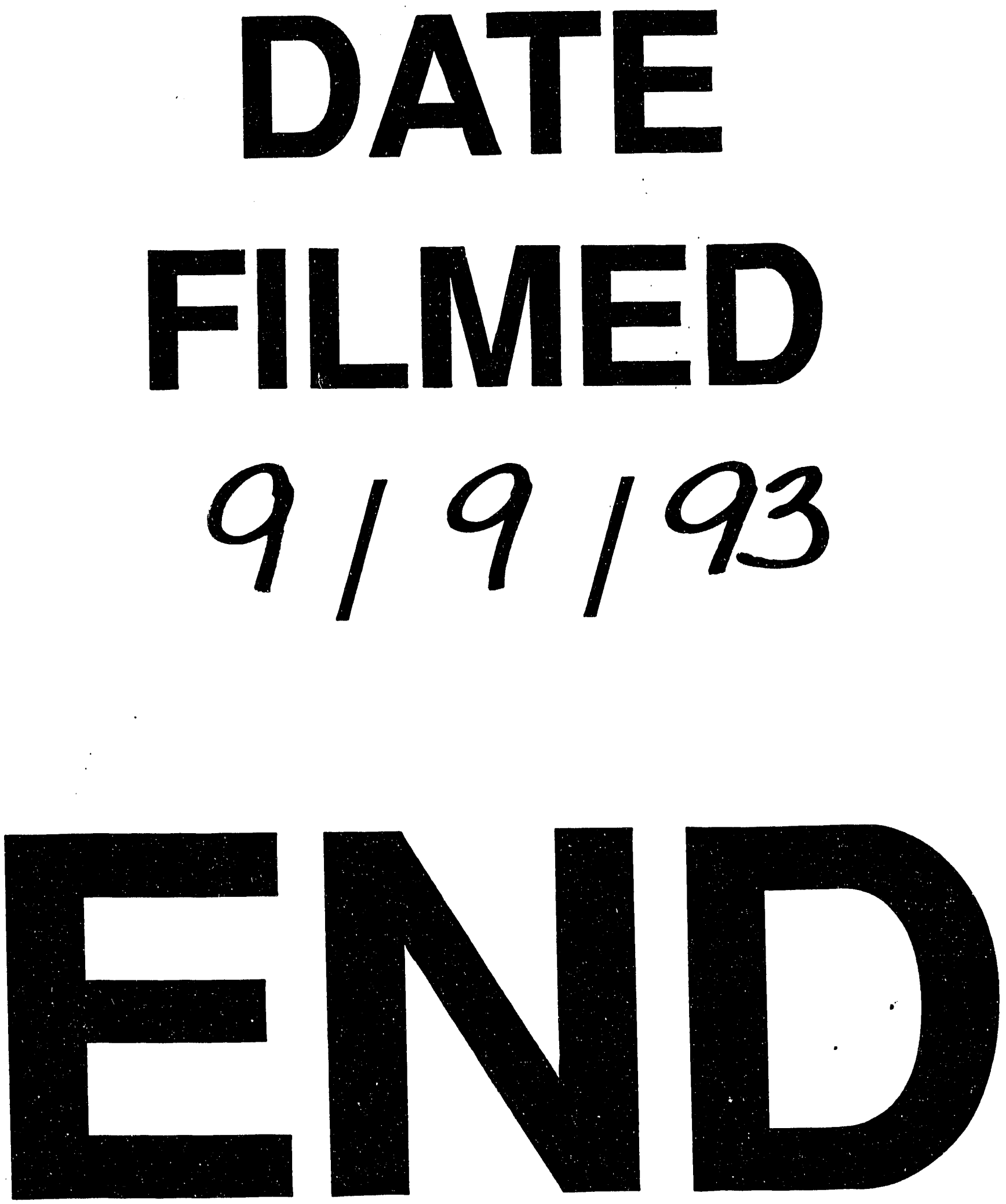
